\title{
INFLUÊNCIA DA FONTE DE LUZ \\ FOTOATIVADORA NA RESISTÊNCIA DE UNIÃO \\ E NA MICROMORFOLOGIA DA INTERFACE ADESIVA DE RESTAURAÇÕES DE RESINA COMPOSTA - UM ESTUDO IN VITRO COM MICROSCOPIA DE FLUORESCÊNCIA
}

\section{Paulo Henrique Perlatti D’Alpino}

Tese apresentada à Faculdade de Odontologia de Bauru, da Universidade de São Paulo, como parte dos requisitos para obtenção do título de Doutor em Odontologia, Área de Dentística.

(Edição Revisada) 


\section{INFLUÊNCIA DA FONTE DE LUZ FOTOATIVADORA NA RESISTÊNCIA DE UNIÃO E NA MICROMORFOLOGIA DA INTERFACE ADESIVA DE RESTAURAÇÕES DE RESINA COMPOSTA - UM ESTUDO IN VITRO COM MICROSCOPIA DE FLUORESCÊNCIA}

Paulo Henrique Perlatti D’Alpino

Tese apresentada à Faculdade de Odontologia de Bauru, da Universidade de São Paulo, como parte dos requisitos para obtenção do título de Doutor em Odontologia, Área de Dentística.

(Edição Revisada)

Orientador:

Prof. Dr. José Carlos Pereira 
D'Alpino, Paulo Henrique Perlatti

D169i Influência da fonte de luz fotoativadora na resistência de união e na micromorfologia da interface adesiva de restaurações de resina composta um estudo com microscopia de fluorescência/ Paulo Henrique Perlatti D'Alpino. Bauru, 2005.

207p. : il. ; 30cm.

Tese. ( Doutorado ) - - Faculdade de Odontologia de Bauru. USP.

Orientador : Prof. Dr. José Carlos Pereira

Autorizo, exclusivamente para fins acadêmicos e científicos, a reprodução total ou parcial desta dissertação, por processos fotocopiadores e outros meios eletrônicos.

Assinatura do autor :

Comitê de Ética da FOB/USP - Projeto de Pesquisa aprovado em: 18 de Outubro de 2001 


\section{PAULO HENRIQUE PERLATTI D’ALPINO}

30 de Junho de 1966

Jaú - SP

1988-1991

$1999-2000$

2001-2005

Associações
Nascimento

Curso de Odontologia - Faculdade de Odontologia de Bauru - USP

Curso de Pós-Graduação em Dentística em nível de Mestrado, na Faculdade de Odontologia de Bauru, USP.

Curso de Pós-Graduação em Dentística em nível de Doutorado, na Faculdade de Odontologia de Bauru, USP

$$
\begin{aligned}
& \text { GBPD - } \text { Grupo Brasileiro de } \\
& \text { Professores de Dentística. } \\
& I A D R-\quad \text { International Association } \\
& \text { For Dental Research. } \\
& \text { SBPQo - Sociedade Brasileira de } \\
& \text { Pesquisa Odontológica. }
\end{aligned}
$$




\section{Dedicatória}

A Deus, por me proporcionar lucidez, inteligência, razão e paixão em todos os momentos de minha vida, especialmente os vividos durante a pós-graduação; pela graça que recebi por poder projetar, desenvolver e finalizar esta tese; pelas experiências proporcionadas durante este período de crescimento pessoal e científico; pelo merecimento de poder viver no exterior e, conhecer e aprender com pessoas tão humildes e geniais; além de todos os momentos felizes com os quais me realizei e, também, os difíceis, com os quais cresci e amadureci;

À minha linda e doce esposa Nádia, que com seu jeito meigo e delicado, seu sorriso e olhos mágicos, e com sua força interior, se juntou a mim nesta jornada, que começou quando nos conhecemos na pós-graduação; que a nossa união perdure por toda nossa vida; e que as lições aprendidas, principalmente quando estivemos a dois no exterior, sejam profundamente assimiladas e nos renovem sempre; tenho por você uma enorme gratidão e espero sempre poder retribuir a confiança e cumplicidade com que abraçou a minha causa; te respeito e te amo muito!!;

À memória de Maria de Fátima de Oliveira, amiga muito especial e minha madrinha de casamento, jamais esquecerei os exemplos de amizade, respeito, incentivo e admiração mútua; peço a Deus que lhe dê paz, conforto e muita luz em seu caminho.......

de coração, dedico esta obra. 


\section{Agradecimentos Especiais à Minha Família}

À minha mãe, Neusa pela compreensão e incentivo durante todos os momentos da pós-graduação; a minha inspiração quando necessitava de muita força; senti muito a sua falta quando no exterior; a você o meu mais profundo respeito e admiração;

Aos meus irmãos Vera Helena e Carlos Alberto, e minha cunhada Luciane por toda colaboração e suporte antes, durante e após a nossa estada nos Estados Unidos; sentimos muita a falta de vocês durante a nossa ausência; e ao meu querido sobrinho e afilhado Lucas, exemplo de alegria, doçura, e carinho; sentimos demais a sua falta;

Ao meu sogro Armando e minha sogra Nadir; não tenho palavras mesmo para expressar o quanto vocês foram importante para que eu e Nádia estivéssemos bem e felizes, muitas vezes poupando a minha família de sofrimentos e não medindo esforços para nos ajudar antes, durante e após o nosso retorno do exterior; agradeço ainda demais pelas orações; tenho muito orgulho de tê-los como sogro e sogra; meu mais profundo respeito e admiração;

a vocês o meu amor, respeito e o meu MUITO OBRIGADO!!!!!! 


\section{Agradecimentos Especiais aos Professores}

Ao meu orientador Prof. Dr. José Carlos Pereira, pelo excelente convívio e constante apoio e incentivo quanto à realização de meus projetos pessoais e científicos; obrigado por confiar no meu trabalho e pela liberdade que permitiu com que desenvolvesse um projeto que eu acreditava; obrigado ainda pelo apoio e empenho para que eu tivesse todas as condições para a realização do Doutorado Sanduíche e da obtenção dos auxílios para os congressos internacionais;

Ao Prof. Dr. Frederick Rueggeberg, por toda a colaboração para que eu realizasse plenamente os projetos que desenvolvi, pelas inúmeras aulas de disciplina, genialidade, desprendimento, generosidade, de respeito a minha pessoa, ao meu trabalho, à minha inteligência, à minha iniciativa e à minha capacidade realizadora e, principalmente, mais do que tudo, pela sua humildade. Foi realmente inacreditável conviver com uma pessoa mundialmente conhecida, tão simples e tão especial;

Ao Prof. Dr. Ricardo Marins de Carvalho, por tudo mesmo o que fez por nós (você nem imagina o quanto!!!), aqui na nossa Faculdade e no exterior, direta e indiretamente, nos abrindo as portas do laboratório do Profs. Rueggeberg e Pashley e de outros departamentos da Medical College of Georgia;

Ao Prof. Dr. David H. Pashley pela colaboração e gentileza com que sempre nos acolheu com relação ao desenvolvimento de meu projeto e pela utilização das facilidades de seu laboratório. Gostaria também de agradecer, principalmente, por acolher Nádia em seu laboratório contribuindo para o seu crescimento pessoal e científico. Ainda, jamais me esquecerei das palavras e das atitudes de incentivo, e dentre outras muitas coisas (muitas mesmo) de que, num dos momentos mais difíceis da realização de meu projeto, me ofereceu o pagamento das primeiras horas da microscopia de fluorescência para a realização dos testes-piloto 


\section{Agradecimentos Especiais às Instituições}

À Faculdade de Odontologia de Bauru da Universidade de São Paulo, a minha escola de Odontologia com a qual estive desde a graduação, pela estrutura que oferece aos alunos, pela minha formação pessoal e científica, pelos amigos que fiz, e as oportunidades que me ofereceu; devo toda a minha formação a esta instituição;; agradeço na pessoa da Profa. Dra. Maria Fidela de Lima Navarro;

À Medical College of Geogia pelo carinho que me recebeu como professor e pesquisador; pelo respeito a minha pessoa; pela possibilidade de utilização de suas facilidades; pelos recursos e oportunidades que me foram oferecidos; pelas pessoas maravilhosas que conheci; agradeço na pessoa do Chefe do Departamento de Reabilitação Oral, Prof. Dr. Caughman e na pessoa da Diretora Dra. Connie L. Drisko;

Aos órgãos de fomento CAPES e, principalmente, CNPq que proporcionou ajuda financeira para o desenvolvimento de meu doutorado sanduíche no exterior;

À Pró-Reitoria de Pós Graduação da Universidade de São Paulo, na pessoa da Pró-Reitora, Profa. Dra. Suely Vilela, pelo empenho em prol dos PósGraduandos e pelo auxílio financeiro para as viagens internacionais

À Comissão de Pós-Graduação da FOB, na pessoa do Prof. Dr. José Carlos Pereira, pelo empenho contínuo para com ensino e à pesquisa; 


\section{Agradecimentos Especiais aos Amigos}

À Sallie Rueggeberg, filhos e família, por tudo que fizeram para que tivéssemos uma feliz estada em Augusta desde o primeiro momento, e por repartir o carinho, atenção e cooperação em todos os momentos que precisávamos e os que vocês previam que precisaríamos; pelo convívio e pelo conforto que nos proporcionaram nos momentos festivos em família; sempre sentimos o conforto de sua família;

À Jennifer Vancise (e seu esposo Dana), secretária do Departamento de Materiais Dentários da Faculdade de Odontologia da Medical College of Georgia, pelos momentos de convivência e amizade que tínhamos diariamente e o carinho especial com a Nádia; obrigado pelo incentivo e pelo ombro amigo em todos os momentos;

À Linda Wang, nossa amiga especial, que em todos os momentos nos cercou de cuidados quando estivemos no exterior, sempre nos dando forças, apoio e incentivo; teremos a sua amizade sempre em nossos corações; os seus telefonemas nos enchiam de alegria e conforto;

À Beth Linder, fiel amiga em todos os momentos, pela sua amizade, carinho, atenção e compreensão durante a nossa estada em Augusta, o nosso anjo brasileiro nos Estados Unidos; jamais vou esquecer o meu aniversário em sua casa 


\section{Agradeço Ainda...}

À Diretora da Faculdade, Prof. Dra. Maria Fidela de Lima Navarro, pela incansável dedicação ao ensino e à pesquisa, digna representante desta Faculdade;

Aos Professores da Disciplina de Dentística Restauradora da Faculdade de Odontologia de Bauru, Prof. Drs. Ricardo; Fidela; Teresa, Eduardo; Rafael; José Mondelli e Francischone, pela dedicação ao ensino e estímulo ao nosso aprendizado;

Aos Professores Maria Teresa Atta, José Henrique Rubo e Silvana Bernardi pelo incentivo e alegria para com as minhas conquistas;

Ao Prof. Katsuya Miyake, professor do Imaging Core Facility da Medical College of Georgia, pela paciência, colaboração para o desenvolvimento da metodologia de análise microscópica da interface adesiva;

Aos especiais amigos Fernanda Garcia e Júlio César pela maravilhosa convivência e prazer de tê-los sempre como verdadeiros amigos;

Aos amigos que fizemos na Medical College of Georgia no departamento do Dr. Rueggeberg: Linda Moss, Pitie Lockwood; Cindy Oxford e família; Don Mettenburg; Sukru Tallas e esposa; Dr. Wataha; Dr. Mackert; Dr. Bill e Martha Brackett; Dr. Daniel Chan e família; Dr. Caughman; Dr. Callan; Dr. Frazier; Dr. Holmes; Dr. Pohjola; Devona;

Aos amigos que fizemos na Medical College of Georgia no departamento do Dr. Pashley: Kelli Agee; Michelle Barnes; Dr. Borke; Dr. Whitford; Nam; Namita; Bakul e esposo; Sonali; Tom Becker; Dr. Ito; Dr. Hashimoto; 
Aos amigos que fizemos em Augusta: Any; John; Lívia; Lilian; Douglas; Cléber; Rômulo; Taís; Dan; Larry; Jeff; Christia e Jerry Ashmore; Jim Scogin;

Ao Prof. Dr. Carlos Ferreira dos Santos, pela amizade, incentivo e colaboração principalmente em relação ao Doutorado Sanduíche;

À amiga Ana Carolina Castro, pelos momentos de amizade, pela colaboração e incentivo;

Aos amigos Rodolfo Mauro Nunhez e Débora Nunhez pelos momentos de amizade e de incrível colaboração nas aulas de inglês;

À Prof. Elisa Oliveira, pelo incentivo e pelo empenho nas aulas de inglês;

Ao Lawrence Gonzaga Lopes, por tudo que fez por mim; jamais esquecerei a sua colaboração; tenho muita gratidão por você;

Aos meus colegas do Doutorado: Celiane, Cláudia, Daniela, Fábio, Juan e Rosa;

Aos meus colegas do Mestrado/ Doutorado: Anuradha, Renato, Eduardo, Terezinha, Flávia, Diego, Leonardo, Luiz Marquezini;

À amiga Eloísa Duran, pela convivência, amizade e carinho para conosco;

Aos Funcionários do Departamento de Dentística, Nelson, Júnior, Dito, Zuleica, Karen, Zilei, Rita, Ângela, Elisabeth, pela convivência, amizade e colaboração para conosco;

Aos Funcionários do Serviço de Biblioteca e Documentação da Faculdade de Odontologia de Bauru, importantes colaboradores dos alunos e professores; 
Agradeço, ainda, a colaboração dos funcionários da MCG: Sras. Beverly Tarver Sue Ward; e Darren Baker (Imaging Core Facility);

À Valéria Cristina Trindade Ferraz, funcionária do Serviço de Biblioteca e Documentação, pela revisão deste trabalho;

Ao Prof. Dr. José Roberto Lauris e Jennifer Waller (MCG), pelos esclarecimentos da análise estatística;

Aos funcionários da reprografia pela colaboração e atenção dispensada;

À Giane e aos funcionários da Secretaria da Pós-Graduação pela atenção e colaboração para com os pós-graduandos;

À 3M ESPE, na pessoa do Sr. John Fundingsland, pela doação dos materiais restauradores utilizados;

Às funcionárias da Clínica de Pós-Graduação, Ana e Cleusa, pela dedicação e paciência com os alunos no transcorrer da clínica;

Aos meus familiares, meu irmão Paulo Sérgio, e aos familiares da Nádia (agora meus também), Tios e Primos, incentivando e apoiando em todos os momentos;

Ao Dr. Abdala Atique, da Direção Regional - D.I.R X Bauru, da Secretaria de Saúde do Estado de São Paulo, pela paciência e colaboração;

A todos que, embora não nominalmente citados, colaboraram direta ou indiretamente durante todo o transcorrer do Doutorado e principalmente na realização deste trabalho. 


\section{SUMÁRIO}

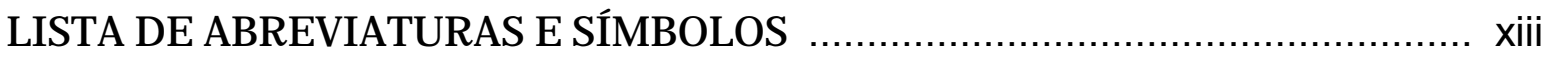

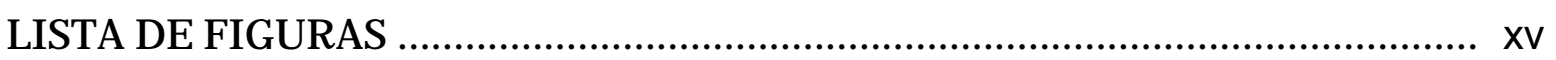

LISTA DE TABELAS ….................................................................... xxi

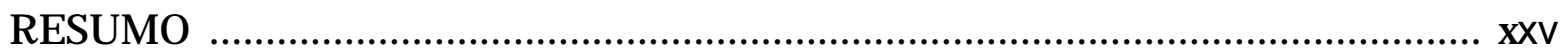

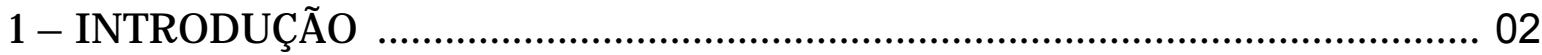

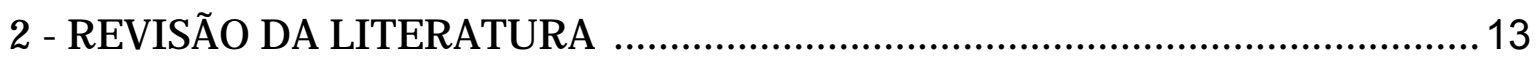

2.1- CINÉTICA DE CONVERSÃO ................................................................. 13

2.2- MICROMORFOLOGIA DA INTERFACE ADESIVA .................................... 37

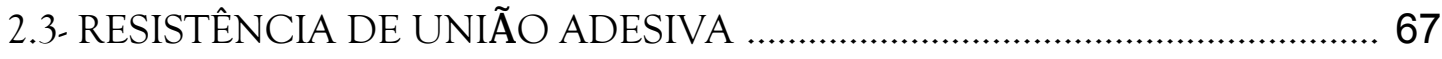

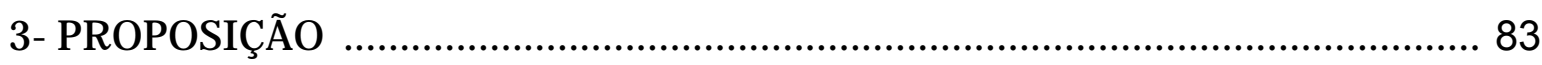

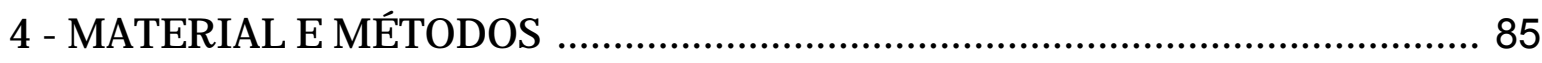

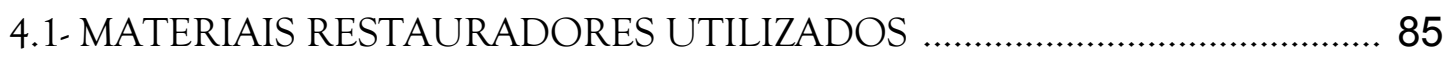

4.2-APARELHOS DE LUZ FOTOATIVADORES UTILIZADOS ....................... 87

4.3- GRUPOS EXPERIMENTAIS .................................................... 91

4.4- AVALIAÇÃO DA CINÉTICA DA CONVERSÃO DE MONÔMEROS ..... 93

4.5- PROCEDIMENTOS RESTAURADORES .................................................... 98

4.6- ANÁLISE DA MICROMORFOLOGIA DA INTERFACE ADESIVA .............. 101

4.7- RESISTÊNCIA DE UNIÃO ADESIVA ............................................................. 112

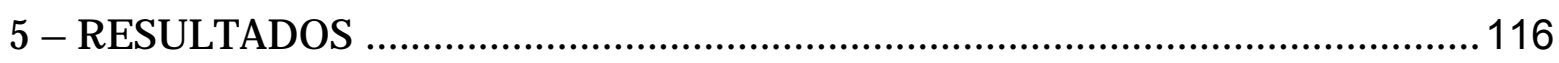

5.1- CINÉTICA DE CONVERSÃO DE MONÔMEROS .......................................... 116

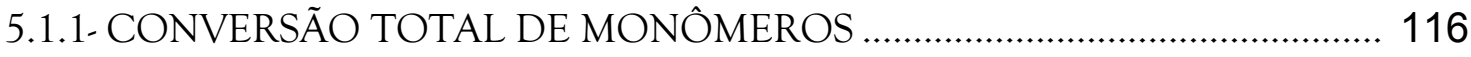


5.1.2- TAXA MÁXIMA DE CONVERSÃO

5.1.3- TEMPO EM QUE OCORREU A MÁXIMA TAXA DE CONVERSÃO ........ 118

5.1.4- CONVERSÃO DE MONÔMEROS NA MÁXIMA TAXA ..............................119

5.1.5- RELAÇÃO CONVERSÃO NA MÁXIMA TAXA E

CONVERSÃO TOTAL 120

5.2- ANÁLISE DA INTERFACE ADESIVA COM MICRO

DE FLUORESCÊNCIA 122

5.2.1- ESPESSURA DE CAMADA DE ADESIVO 122

5.2.2- ESPESSURA DE CAMADA HÍBRIDA 123

5.2.3- QUALIDADE DA CAMADA HÍBRIDA. 125

5.2.4- TESTE DE MICROPERMEABILIDADE 128

5.2.5- AVALIAÇÃO DOS TAGS DE RESINA 133

5.2.6- AVALIAÇÃO DE FENDAS 138

5.2.7- RESISTÊNCIA DE UNIÃO ADESIVA 144

6 - DISCUSSÃO 149

6.1- CINÉTICA DA CONVERSÃO DE MONÔMEROS 149

6.2- ANÁLISE DA MICROMORFOLOGIA DA INTERFACE ADESIVA 155

6.3- RESISTÊNCIA DE UNIÃO ADESIVA 167

7 - CONCLUSÕES 175

ANEXO 178

REFERÊNCIAS BIBLIOGRÁFICAS 185 


\section{LISTA DE ABREVIATURAS E SÍMBOLOS}

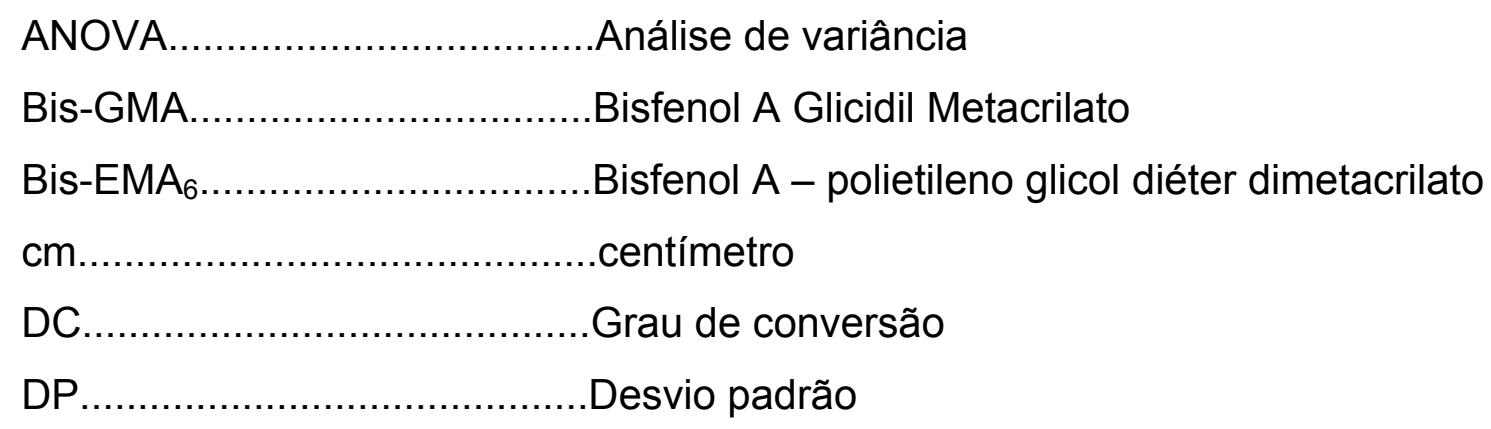

Fig. Figura

FT-IR

Espectrofotômetro de raios infravermelho

${ }^{\circ} \mathrm{C}$. Graus Celsius

HEMA

2-hidroxietil metacrilato

$\mathrm{H}_{3} \mathrm{PO}_{4}$ ácido fosfórico

$\mathrm{Kg} / \mathrm{cm}^{2}$ quilograma por centímetro ao quadrado

LED. aparelho fotoativador com diodos emissores de luz

azul

MEV microscopia eletrônica de varredura

$\mathrm{mg}$. miligramas

$\mu \mathrm{m}$ micrômetro

$\mu \mathrm{l}$. microlitros

$\mathrm{mm}$ milímetro

$\min$ minuto

$\mathrm{MPa}$ Mega pascal

$\mathrm{MNm}$. Meganewton por metro $\mathrm{mW} / \mathrm{cm}^{2}$ Miliwatt por centímetro ao quadrado

$\mathrm{N}$ Newton

NA abertura numérica

nm. nanômetro

PAC .aparelho fotoativador com arco de plasma $\mathrm{pH}$ potencial hidrogeniônico 


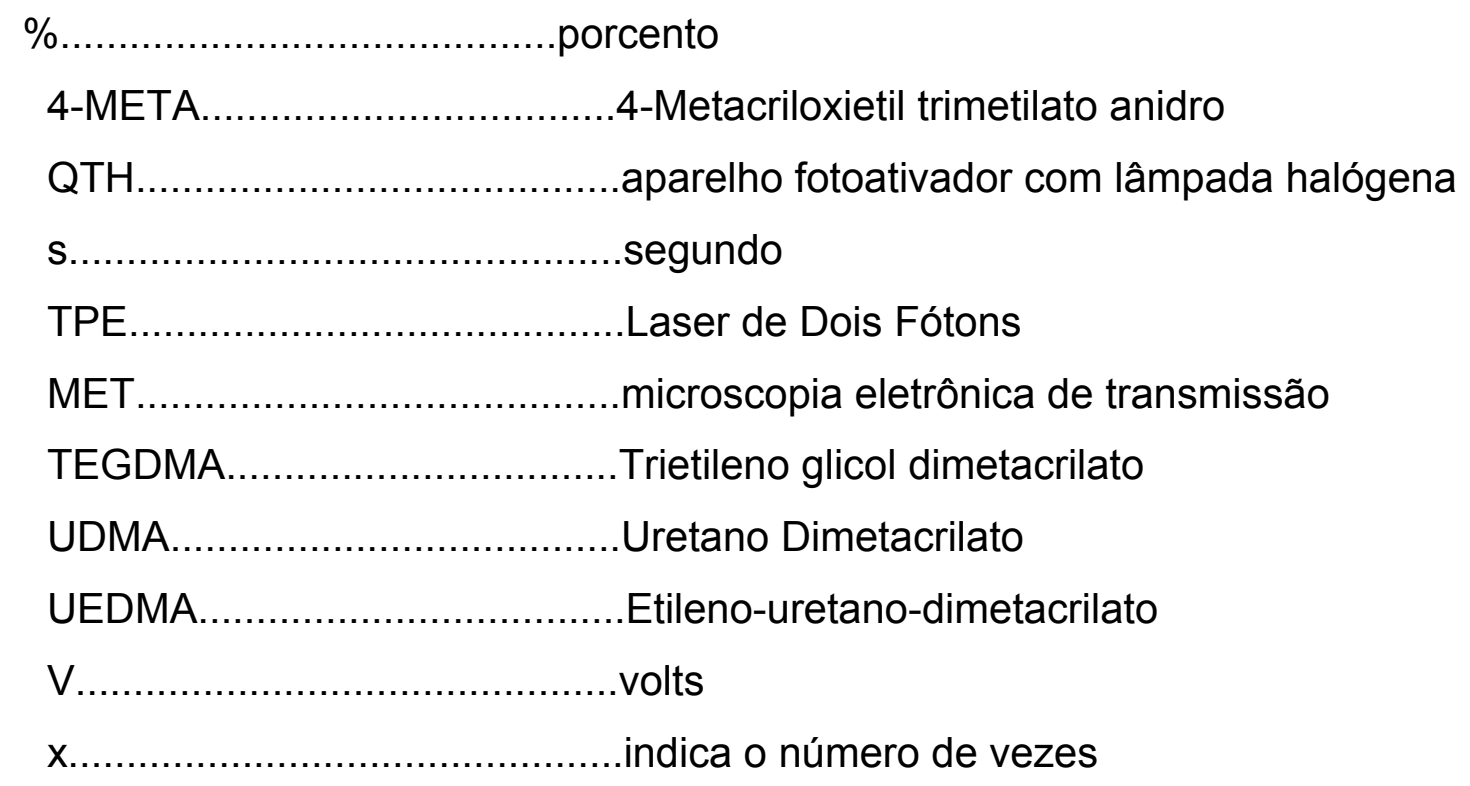




\section{LISTA DE FIGURAS}

Figura 1 - Interpenetração de adesivo na intimidade dos túbulos; microscopia após a descalcificação da dentina

Figura 2 - Preparos cavitários proximais realizados para análise da interface adesiva.

Figura 3 - Distribuição dos monômeros do primer do sistema adesivo Scotchbond MP destacado em vermelho.

Figura 4 - Distribuição dos monômeros do adesivo do Scotchbond MP destacada na cor verde

Figura 5 - Fotomicrografia mostrando a interface adesiva formada com Syntac, destacada pela adição de Rodamina $B$.

Figura 6 - Fotomicrografia mostrando a interface adesiva formada com Gluma CPS, destacada pela adição de Rodamina B

Figura 7 - Fotomicrografia mostrando a interface adesiva do adesivo Scotchbond MP, destacada pela adição de Rodamina B

Figura 8 - Diagrama do teste de micropermeabilidade: 1- sem micropermeabilidade; 2micropermeabilidade ao redor dos tags de resina; 3- micropermeabilidade na base da camada híbrida; 4- micropermeabilidade na camada híbrida propriamente dita.

Figura 9 - Fotomicrografia em MEV mostrando a interface adesiva do sistema adesivo Syntac; destaca-se (seta branca) a camada híbrida.

Figura 10 - Fotomicrografia em confocal; interface adesiva do Gluma CPS. 49

Figura 11 - Preparo cavitário classe I realizado para análise da interface adesiva. .50

Figura 12 - Superfícies planas de dentina foram restauradas para análise comparativa da interface adesiva. 
Figura 13 - Fotomicrografia da interface formada pelo sistema adesivo Syntac, observada em MEV.

Figura 14 - Fotomicrografia da interface formada pelo sistema adesivo Optibond, observada em confocal.

Figura 15 - Fotomicrografia da interface formada quando Optibond foi aplicado; observada em microscopia confocal.

Figura 16 - Representação esquemática do processo de excitação de um corante fluorescente com Confocal convencional $\left(\lambda_{1}\right)$ e com Laser de Fóton Duplo $\left(\lambda_{A} e_{B}\right)$.

Figura 17 - Curvas de absorção (A) e emissão (B) da Rodamina B em Laser de Fóton Duplo. .56

Figura 18 - Curvas de absorção (A) e emissão (B) da Fluoresceína em Laser de Fóton Duplo .56

Figura 19 - Fotomicrografia da interface formada quando Prime \& Bond NT foi aplicado; observada em microscopia confocal.

Figura 20 - Fotomicrografia em MEV da interface formada com fenda presente na parede axial quando Single Bond/Filtek A110 foram aplicados. .59

Figura 21 - Fotomicrografia em MEV da interface livre de fenda na parede axial quando Single Bond/Filtek Z250 foram aplicados.

Figura 22 - Fotomicrografia da interface formada com Single Bond em MEV; destaca-se a espessura da camada híbrida

Figura 23 - Fotomicrografia da interface adesiva formada em microscopia confocal; destacam-se a presença da camada híbrida e de tags de resina

Figura 24 - Fotomicrografia em MEV da superfície de dentina sem remoção da smear layer. .64 
Figura 25 - Fotomicrografia em MEV mostrando gotículas de transudato na dentina condicionada com ácido fosfórico/ aplicação Single Bond

Figura 26 - Representação esquemática do mecanismo de formação de fendas devido à ação das forças de contração de polimerização

Figura 27 - Curva mostrando a relação contração x tempo, demonstrando que a última parte da contração pós-gel é a que causa a formação de fendas.

Figura 28 - Comparativo das curvas de tensão resultante de diferentes configurações cavitárias avaliadas 79

Figura 29 - Diferentes formas de aplicação da resina composta utilizada no estudo

Figura 30 - Valores de resistência adesiva Single Bond x forma de aplicação da resina composta...80

Figura 31 - Sistema adesivo Adper Single Bond (A); número de lote no destaque (B) .86

Figura 32 - Resina composta Filtek Z250 (C); em destaque o número de lote (D)....... 86

Figura 33 - Espectro de irradiância dos aparelhos fotoativadores utilizados. .88

Figura 34 - Aparelhos de luz fotoativadora utilizados no estudo A - QTH; B- LED; C - PAC 90

Figura 35 - A : Aparelho espectrofotômetro de raios infravermelhos (FT-IR)

B: Detalhe da mesa ATR. .93

Figura 36 - Representação esquemática dos raios infravermelhos incidentes no cristal localizado no centro do ATR e a reflexão dos mesmos no interior do cristal... 95

Figura 37 - Curvas de absorção das duplas ligações de carbono nas cadeias alifáticas antes (A) e depois (B) do processo de fotoativação; após 300 segundos, verifica-se a redução no pico de absorção no comprimento de onda de $-1.636 \mathrm{~cm}^{-1}$..... .96 
Figura 38 - Terceiro molar hígido utilizado na amostra (A); redução das cúspides (B) até o sulco intercuspídeo ocluso-vestibular (C)

Figura 39 - Dimensões do preparo cavitário, por oclusal (A) e por "vestibular" (B). 99

Figura 40 - Sistema adesivo com adição de corante fluorescente Rodamina B; o corante fluoresce quando excitado no comprimento de onda adequado, destaca-se a distribuição do sistema adesivo na dentina desmineralizada.

Figura 41 - Aspecto final dos dentes restaurados após a adição de corante fluorescente vermelho ao sistema adesivo estudado

Figura 42 - Aplicação do corante fluorescente Fluoresceína à câmara pulpar (B), depois do seccionamento $(A)$ e correto posicionamento do espécime.

Figura 43 - Seccionamento dos dentes em máquina de corte (A); fixação dos espécimes em lâmina de vidro para microscopia (B). 106

Figura 44 - Sobreposição de curvas de emissão de fluorescência dos corantes Rodamina B (linha tracejada) e Fluoresceína (linha contínua); filtros removiam a área de overlapping ( A ), evitando-se resultados falso-positivos

Figura 45 - Fotomicrografia da interface adesiva e estruturas adjacentes 107

Figura 46 - Representação esquemática da análise da micropermeabilidade (*): (A) Selamento "perfeito"; (B) Penetração do corante até a base da camada híbrida; (C) Penetração do corante na camada híbrida; (D) Penetração do corante entre a camada híbrida e a camada de adesivo e/ou na camada de adesivo; (E) Penetração do corante entre a camada de adesivo e a resina composta. 
Figura 47 - Aspecto final do dente após adição de resina composta sobre a restauração final para o teste de microtração

Figura 48 - Espécime colocado no dispositivo para a realização do teste de resistência adesiva; as extremidades são afixadas com cola com a interface adesiva perpendicular à direção da ação das forças de tração

Figura 49 - Influência da luz fotoativadora na conversão de monômeros do sistema adesivo e da resina composta (base).

Figura 50 - Influência da fonte de luz fotoativadora na relação conversão na máxima taxa e a conversão total em porcentagem.

Figura 51 - Distribuição dos escores de alta qualidade de camada híbrida nos diferentes grupos experimentais.

Figura 52 - Distribuição dos escores de baixa qualidade de camada híbrida nos diferentes grupos experimentais.

Figura 53 - Distribuição decrescente dos escores 1 e 2 para micropermeabilidade nos grupos experimentais

Figura 54 - Distribuição percentual do escore 3 para micropermeabilidade em ordem crescente nos grupos experimentais.

Figura 55 - Distribuição da porcentagem dos escores 4 e 5, em ordem crescente, de micropermeabilidade nos grupos experimentais.

Figura 56 - Concentração de escore $3(\%)$ da qualidade dos tags de resina para os diferentes grupos experimentais, distribuídos em ordem decrescente. 136

Figura 57 - Distribuição em ordem decrescente dos piores escores de habilidade de selamento dos tags de resina nos diferentes grupos experimentais.

Figura 58 - Distribuição dos escores 1 e 2 para presença de fendas de acordo com as combinações de fonte de luz utilizadas. 
Figura 59 - Distribuição dos escores 5, 6 e 7 para presença de fendas em ordem decrescente.

Figura 60 - Presença de fendas entre a camada de adesivo e a camada híbrida, independente da presença de corante verde (escores 4 e 5 )

Figura 61 - Valores de porcentagem de extensão de fendas organizados em ordem decrescente.

Figura 62 - Valores de resistência adesiva (MPa) em ordem decrescente

Figura 63 - Valores de resistência adesiva de acordo com as diferentes combinações de fonte de luz fotoativadora 


\section{LISTA DE TABELAS}

Tabela 1 - Características dos materiais restauradores utilizados.

Tabela 2 - Aparelhos de luz fotoativadora utilizados no estudo

Tabela 3 - Avaliações realizadas na primeira fase da metodologia

Tabela 4 - Grupos experimentais

Tabela 5 - Porcentagem de conversão de monômeros após 300 segundos (Tukey; $p<0,05$ ).

Tabela 6 - Taxa máxima de conversão em porcentagem por segundo (Tukey, $p<0,05$ )

Tabela 7- Tempo em que ocorreu a máxima taxa de conversão em segundos (Tukey; $p<0,05) \ldots . .119$

Tabela 8- Conversão de monômeros na máxima taxa em porcentagem.

Tabela 9- Influência da fonte de luz fotoativadora na relação conversão na máxima taxa e a conversão total em porcentagem

Tabela 10- Valores de espessura da camada de adesivo e comparações estatísticas entre os diferentes grupos experimentais.

Tabela 11- Influência da fonte de luz fotoativadora sobre a espessura da camada de adesivo. 123

Tabela 12- Valores de espessura de camada híbrida e comparações estatísticas entre diferentes grupos experimentais.

Tabela 13- Influência da fonte de luz fotoativadora sobre a espessura da camada híbrida.

Tabela 14- Escores de qualidade de camada híbrida e comparações estatísticas entre os diferentes grupos experimentais

Tabela 15- Influência da fonte de luz fotoativadora sobre a qualidade da camada híbrida. 126 xxi 
Tabela 16- Distribuição comparativa da porcentagem dos escores de qualidade de camada híbrida nos diferentes grupos experimentais

Tabela 17- Escores médios de micropermeabilidade e comparações estatísticas entre os diferentes grupos experimentais (Kruskal-Wallis)

Tabela 18- Influência da fonte de luz fotoativadora sobre micropermeabilidade.

Tabela 19- Distribuição da porcentagem dos escores de micropermeabilidade nos grupos experimentais

Tabela 20- Resultados da avaliação dos tags de resina nos diferentes grupos experimentais (Kruskal-Wallis).

Tabela 21- Influência da fonte de luz fotoativadora sobre a qualidade dos tags de resina.

Tabela 22- Influência da fonte de luz fotoativadora sobre a habilidade de selamento dos tags de resina

Tabela 23- Distribuição da porcentagem de escores de qualidade dos tags de resina nos diferentes grupos experimentais

Tabela 24- Porcentagem de escores de habilidade de selamento dos tags de resina nos diferentes grupos experimentais

Tabela 25- Resultados da avaliação da localização e extensão de fendas nos diferentes grupos experimentais

Tabela 26- Influência da fonte de luz fotoativadora do sistema adesivo sobre a localização de fendas.

Tabela 27- Influência da fonte de luz fotoativadora da resina composta sobre a localização de fendas.

Tabela 28- Distribuição da porcentagem de escores de localização de fendas nos diferentes grupos experimentais. 
Tabela 29 - Valores de resistência adesiva nos diferentes grupos experimentais...

Tabela 30 - Influência da fonte de luz foativadora sobre os materiais restauradores utilizados. 146 


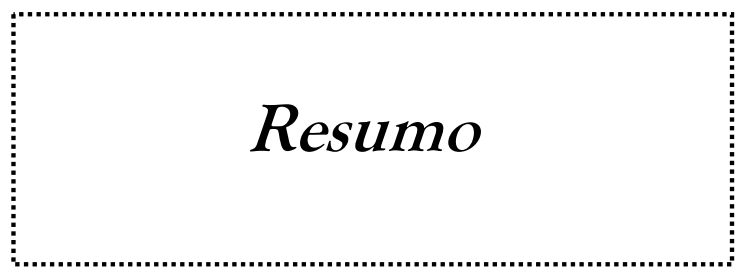




\section{RESUMO}

Propôs-se avaliar a influência de diferentes fontes de luz fotoativadoras na micromorfologia e na resistência de união adesiva de restaurações de resina composta. Selecionaram-se terceiros molares hígidos que receberam preparos cavitários classe I (6,0 mm x 4,5 mm;2,5 mm profundidade). A resina composta (Filtek Z250 - RC) foi inserida em incremento único após a aplicação e polimerização do sistema adesivo (Adper Single Bond - SB). Os materiais restauradores foram fotoativados com os seguintes aparelhos: XL 3000 (QTH: $540 \mathrm{~mW} / \mathrm{cm}^{2}$ ); Elipar FreeLight 2 (LED: $750 \mathrm{~mW} / \mathrm{cm}^{2}$ ) e Arc Light IIM (PAC: $2.130 \mathrm{~mW} / \mathrm{cm}^{2}$ ). Nove grupos experimentais foram avaliados de acordo com as combinações de fonte de luz para fotoativar SB/RC: QTH/QTH; QTH/LED; QTH/PAC; LED/LED; LED/QTH; LED/PAC; PAC/PAC; PAC/QTH; PAC/LED. Para a análise da micromorfologia foi utilizada microscopia de fluorescência (Laser de Fóton Duplo), sendo que um corante fluorescente vermelho (Rodamina B) foi adicionado ao sistema adesivo. Além disso, utilizou-se uma solução de corante fluorescente verde (Dextran-Fluoresceína), que foi aplicada na câmara pulpar durante 4 horas, para que se difundisse em direção à interface. Os dentes foram então lavados, incluídos, seccionados e analisados microscopicamente. Os parâmetros analisados foram: espessura da camada de adesivo, espessura e qualidade da camada híbrida, micropermeabilidade, qualidade e habilidade de selamento dos tags de resina e, ainda, localização e extensão de fendas. Para o teste de resistência adesiva, os dentes foram restaurados, de acordo com as combinações de fonte de luz, e armazenados por 24 horas a $37{ }^{\circ} \mathrm{C}$. Em seguida os dentes foram seccionados e submetidos ao teste de microtração. Realizou-se ainda a análise dos parâmetros de cinética de conversão de monômeros (conversão total, taxa máxima de conversão, conversão na máxima taxa, tempo em que ocorreu a máxima taxa e relação conversão na máxima taxa/conversão total) em um espectrofotômetro de raios infravermelho, ao qual foram aplicados os mesmos materiais restauradores que foram polimerizados com as diferentes fontes de luz. Para as avaliações qualitativas foi realizado o teste estatístico Kruskal-Wallis e o teste de Dunnet para comparações múltiplas $(\alpha=0,05)$. 
Para as avaliações quantitativas foi realizada análise de variância e teste de Tukey para comparações múltiplas $(\alpha=0,05)$. Da análise dos resultados, observou-se que as fontes de luz utilizadas influenciaram nos parâmetros de cinética de conversão de monômeros. De forma geral, ocorreu uma relação inversa entre a conversão total e a densidade de potência quando se polimerizou o sistema adesivo. Na resina composta base, houve uma relação direta. Para ambos os materiais houve uma maior taxa máxima de conversão, em um menor tempo, proporcional à densidade de potência dos aparelhos. Quanto aos parâmetros de micromorfologia, não se observou diferença siginificante entre os grupos experimentais em relação à espessura e qualidade de camada híbrida. Em relação à espessura da camada de adesivo, observaram-se maiores espessuras quando o sistema adesivo foi polimerizado com o PAC. Para a micropermeabilidade, também não se observou diferença entre os grupos. Também, não se observou diferença siginificante em relação à qualidade e habilidade de selamento dos tags de resina. Em relação à presença de fendas, quando o PAC polimerizou o sistema adesivo, menores porcentagens de piores escores e menores extensões de fendas foram observadas. A combinação PAC/QTH apresentou valores significantemente maiores de resistência adesiva e LED/QTH, as menores. A espessura da camada de adesivo, localização de fendas e resistência adesiva foram significantemente influenciados pela fonte de luz que polimerizou o sistema adesivo, sendo que, quando o PAC foi utilizado, melhores resultados foram observados. As combinações de mesma fonte de luz apresentaram, de forma geral, resultados similares. As diferentes fontes de luz fotoativadoras influenciam na resistência de união adesiva e em alguns parâmetros da micromorfologia da interface de restaurações de resina composta. 
$1-$ Introducão 


\section{1- Introdução}

A realização de procedimentos restauradores adesivos tornou-se uma rotina na clínica odontológica ${ }^{173}$. As resinas compostas existentes atualmente no mercado tiveram suas propriedades mecânicas melhoradas, com aumento da resistência ao desgaste e uma melhor estética. Além disso, a evolução dos sistemas adesivos possibilitou a obtenção de maior resistência adesiva deste material restaurador à dentina previamente condicionada com ácido fosfórico ${ }^{36,78}$ e menor infiltração marginal $^{3}$. A magnitude desta resistência adesiva pode ser ainda maior em esmalte, possibilitando ampla utilização das resinas compostas, as quais tem demonstrado grande eficácia na manutenção da integridade estrutural da coroa dentária.

Apesar da constante evolução destes materiais, uma série de fatores deve ser levada em consideração para que haja uma correta adaptação e, principalmente, retenção dos mesmos às paredes e margens cavitárias. Quando se fala em restaurações de resina composta, os fatores mais relevantes que devem ser levados em consideração são a contração de polimerização, a viscosidade e o módulo de elasticidade. Além disso, a flexibilidade das paredes das cavidades e o procedimento adesivo propriamente dito também são fatores a se considerar $^{31,46}$. Adicionalmente, o conhecimento das variações dos substratos dentários, somado às diferentes características dos sistemas adesivos, são extremamente importantes para se obter restaurações adesivas com maior longevidade ${ }^{117,151}$.

A contração de polimerização é um processo que se segue à fotoativação destes materiais, pela aproximação das moléculas dos monômeros, criando forças em torno de 17 a $20 \mathrm{MPa}$ cuja resultante é transmitida às paredes cavitárias adjacentes $^{111}$. As tensões de contração são correlacionadas às fraturas coronárias e à sensibilidade pós-operatória ${ }^{18,159}$. Estas tensões são absorvidas, na maioria das vezes, somente se apropriadamente compensadas pelo comportamento viscoelástico do material restaurador ou da estrutura dentária, sem que haja a criação de fendas marginais ${ }^{27}$. Por outro lado, pode haver formação de fendas marginais de 10 a $15 \mu \mathrm{m}$ que permanecem abertas, mesmo após a absorção tardia de água pela resina composta ${ }^{177}$. Falhas adesivas podem ainda ocorrer nas paredes internas, levando à formação de fendas entre o material restaurador e a superfície da 
dentina ${ }^{55}$. Tais fendas ou espaços são considerados prejudiciais à longevidade das restaurações adesivas, uma vez que permitem a passagem de fluidos ou substâncias entre o complexo dentina-polpa e a cavidade bucal ${ }^{94}$. A contração de polimerização da resina composta aliada a baixos valores de resistência adesiva são considerados os mais importantes fatores responsáveis pela formação de fendas marginais em restaurações adesivas ${ }^{30,119}$.

As tensões geradas pela contração basicamente depende do volume de resina composta aplicada à cavidade, principalmente quando inserida a preparos tipo caixa e na forma de incremento único ${ }^{18}$. DAVIDSON et al. ${ }^{31,46}$ descreveram o fator de configuração cavitária, ou fator "C", no qual a tensão gerada é proporcional à razão entre área de superfície aderida e área de superfície não aderida. Quanto maior o fator "C", maior a competição entre a força de adesão à dentina e as forças de contração de polimerização, podendo levar ao rompimento das ligações na interface adesiva. Técnicas de fotoativação que fornecem a máxima intensidade de luz, causando o endurecimento da resina composta em poucos segundos, comprometem severamente o seu escoamento $0^{60}$, principalmente em cavidades com alto fator "C". O calor gerado leva ainda a um aumento adicional na velocidade de polimerização, que se traduz em rápido aumento na viscosidade das resinas compostas $^{101}$. A velocidade com que ocorre o processo de polimerização e a conseqüente contração está relacionada com intensidade e tempo de exposição da luz fotoativadora ${ }^{137}$. Isto reflete na velocidade com que os monômeros se convertem em polímero durante o processo de polimerização da resina composta, denominada taxa de conversão. Há na literatura um consenso quanto à correlação entre o tempo em que ocorre a taxa máxima de conversão e a contração de polimerização ${ }^{47,92,137 .}$ Quanto mais rápido se atinge o ponto gel, menor a possibilidade de rearranjo das moléculas e, conseqüentemente, menor a possibilidade de escoamento da resina $\mathrm{e}$ da dissipação das forças da contração de polimerização que causam desunião na interface adesiva ${ }^{143}$.

Os aparelhos fotoativadores de arco de plasma surgiram na década de 90 com o intuito de possibilitar ao profissional uma redução do tempo operatório para realização de restaurações de resina composta, pela utilização de altíssima densidade de potência em curtos espaços de tempo ${ }^{137}$. Mas, o que parecia ideal em 
termos econômicos para os clínicos, se tornou inviável em termos de longevidade da restauração, já que testes clínicos e laboratoriais mostraram resultados inferiores, quando comparados aos tradicionais aparelhos com lâmpada halógena ${ }^{21,158}$. Além disso, outros estudos mostraram que a tão aclamada economia de tempo clínico (com a utilização de um tempo de exposição de três segundos) não era adequada para uma correta polimerização e para garantir as propriedades mecânicas ideais das resinas compostas ${ }^{76,88,101}$. Assim, um tempo de cerca de 10 segundos foi então considerado ideal para que se obtivessem propriedades mecânicas comparáveis às obtidas quando se utilizavam os aparelhos convencionais, mas, ainda assim com prejuízo para selamento das margens cavitárias ${ }^{101,121 .}$

Apesar da contração de polimerização ocorrer inevitavelmente, por ser uma característica inerente às resinas compostas, independentemente da técnica polimerizadora, as tensões resultantes deste processo podem ser controladas pelo profissional. Recentemente alguns estudos têm demonstrado que técnicas que utilizam modulação da intensidade inicial de luz podem melhorar a qualidade da adaptação interna e da integridade marginal de restaurações adesivas ${ }^{93,137}$. Uma contração de polimerização controlada, pela redução da intensidade de luz inicial, seguida de uma fotoativação com alta intensidade, deve proporcionar maior longevidade das restaurações de resina, permitindo melhor adaptação e manutenção das suas propriedades mecânicas ${ }^{95,178,179}$. Por outro lado, estudos mais recentes ${ }^{5,120}$ têm mostrado que quando se utilizaram algumas técnicas de modulação da intensidade de luz, devido à ocorrência de um reduzido grau de conversão e de menor formação de ligações cruzadas, pode ocorrer um efeito plastificador ${ }^{113}$, exercido pela água, sobre as resinas que foram fotoativadas desta forma. Este efeito promove um "amolecimento" (softening) ${ }^{120}$ da resina a curto ou longo prazos com prejuízos à longevidade das mesmas.

Os aparelhos de luz fotoativadora também mostraram evolução significativa. Alguns apresentam diferentes recursos quanto à modulação da intensidade de luz, bem como diferentes tempos de exposição. Além disso, novas tecnologias estão em desenvolvimento, como aparelhos com diodos emissores de luz (LED), os quais têm sido amplamente divulgados por sua efetividade em termos de cinética de conversão de monômeros, quando comparado aos aparelhos de luz halógena e aos de arco de 
plasma $^{101}$. Os primeiros aparelhos deste tipo, que apresentavam um design simples com baixa densidade de potência e múltiplos LEDs, evoluíram consideravelmente. As fontes de luz contendo LED mais modernas apresentam uma complexa tecnologia e na maioria das vezes um único diodo, com alta densidade de potência, às vezes até necessitando de refrigeração. Com o aumento da densidade de potência deste tipo de fonte de luz, possibilitou-se uma maior profundidade de polimerização das resinas compostas comerciais ${ }^{6}$, conferindo propriedades mecânicas semelhantes, ou até superiores, quando comparadas com a fotoativação com outros tipos de luz ${ }^{102}$. Apesar disso, os problemas relacionados à contração de polimerização ainda persistem ${ }^{137}$.

Recentemente, com o intuito de minimizar os efeitos da contração de polimerização, o conceito de densidade de energia tem sido amplamente estudado. A densidade de energia (ou dose) é baseada na densidade de potência e no tempo de exposição da irradiação. Assim, um tempo curto de exposição com uma alta densidade de potência pode ter a mesma densidade de energia de longo tempo de exposição com uma menor densidade de potência. A utilização atual deste conceito está baseada neste último caso, uma vez que tempos mais longos de exposições em baixa intensidade de luz levam a um maior grau de conversão ${ }^{120,}{ }^{144}$, prolongando-se, assim o tempo em que ocorre o ponto gel ${ }^{144}$. Tem-se afirmado que a densidade de energia influencia o grau de conversão, profundidade de

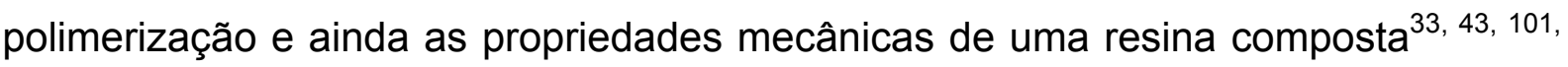
120,138

Apesar da evolução das resinas compostas e das fontes de luz fotoativadoras, falhas clínicas das restaurações adesivas como a infiltração marginal, a sensibilidade pós-operatória e a irritação pulpar são ainda freqüentemente relacionadas aos procedimento adesivo ${ }^{50}$. A idéia original da criação da camada híbrida, uma zona de interdifusão entre dentina desmineralizada e resina composta, era de melhorar a adaptação do material às paredes cavitárias e, principalmente, tentar eliminar as fendas marginais e internas ${ }^{97}$. Apesar do selamento da restauração ser comprovadamente eficaz quando o procedimento adesivo é realizado em margens de esmalte dentário, ainda não se obteve um selamento aceitável das mesmas quando localizadas em dentina, principalmente quando se 
trata da parede gengival ${ }^{115,180}$. A habilidade do sistema adesivo em selar os túbulos dentinários é um dos maiores requisitos a ser alcançado para a longevidade de restaurações adesivas in vivo quando as margens de dentina são expostas ao meio bucal. Além disso, há a preocupação de que o condicionamento ácido dos sistemas adesivos convencionais de dois ou três passos remove, além da smear layer e dos smear plugs, cálcio e fosfato da dentina intertubular, bem como parte da matriz dentinária peritubular ${ }^{164}$. O condicionamento ácido também produz profundas alterações na composição química e física da matriz dentinária, podendo influenciar na qualidade das ligações adesivas, na resistência adesiva, e conseqüentemente, na longevidade das restaurações ${ }^{107}$.

A formação da interface adesiva ocorre pela interdifusão dos monômeros resinosos por entre a trama de fibrilas de colágeno na superfície desmineralizada da dentina. Estes monômeros são levados na intimidade da dentina pela ação dos solventes, que são volatilizados após a aplicação do sistema adesivo. A permeação do sistema adesivo por entre as microporosidades formadas no substrato dentinário, não somente permitirá um embricamento mecânico ao redor das fibrilas de colágeno, mas também promoverá uma união entre sistema adesivo e resina composta $^{182}$. A união adesiva, que se baseia na hibridização do substrato dentinário, tem proporcionado maior resistência adesiva, especialmente se realizado em substrato umedecido, ao invés de desidratado ${ }^{85,97}$. A presença da água evita o colapso da rede de fibrilas de colágeno, permitindo a infiltração e interpenetração de monômeros que serão polimerizados na intimidade da dentina, formando a camada híbrida. Os tags de resina são também formados durante a hibridização do substrato dentinário desmineralizado, devendo selar os túbulos dentinários abertos pelo condicionamento ácido.

A formação de um efetivo selamento e conseqüente eliminação da infiltração marginal está mais baseada na habilidade do sistema adesivo em ocluir os túbulos dentinários, do que na extensão absoluta dos tags de resina ${ }^{64}$. Além disso, uma vez que os sistemas adesivos são capazes de permear o substrato dentinário desmineralizado, espera-se o movimento de fluidos através da dentina seja completamente eliminado, desde que os túbulos dentinários estejam, pelo menos, fisicamente ocluídos pela formação dos tags de resina ${ }^{10}$. A importância de um 
selamento efetivo promovido pelos tags no interior dos túbulos é desconhecido, mas a união com a dentina peritubular deve ser de fundamental importância para a longevidade das uniões adesivas ${ }^{130}$. Acredita-se ainda que a rede de tags de resina interconectados é fundamental para o desenvolvimento de uma união adesiva mais forte $^{22}$. No entanto, a eficiência dos tags de resina ainda não foi totalmente avaliada e a sua capacidade de selar túbulos dentinários ainda não está totalmente esclarecido. É possível que a contração de polimerização promova a remoção ou deslocamento dos tags de resina dos túbulos dentinários, criando fendas microscópicas de tamanho suficiente para permitir o trânsito de fluidos ${ }^{64}$. Testes de permeabilidade têm demonstrado o movimento de fluidos através da interface formada quando se utilizaram diferentes sistemas adesivos. Destes, os adesivos convencionais são os que mostraram piores resultados ${ }^{70}$.

Os sistemas adesivos passaram por grande evolução, o que não significou, necessariamente, maior longevidade para as restaurações ${ }^{23}$. Os sistemas adesivos mais modernos são formados pela combinação de monômeros hidrofóbicos e hidrofílicos, devido à natureza intrinsecamente úmida do substrato dentinário. Esta modificação fez com que houvesse um aumento potencial de absorção de água pelos sistemas adesivos, levando à alterações nos polímeros formados e conseqüente degradação da interface adesiva $^{15}$. Além disso, a mistura de monômeros hidrofílicos e hidrofóbicos representa outro problema pela potencial separação física, como a mistura "água e óleo", ao interagir com a dentina úmida desmineralizada. Desta forma, deve ocorrer uma separação dos componentes em uma fase rica em BisGMA que é hidrofóbico e outra rica HEMA que é hidrofílico, principalmente na parede gengival de cavidades de classe II e V, onde há possibilidade do acúmulo de água ${ }^{113}$. SPENCER et al. ${ }^{157}$ mencionaram que, devido a este fato, a rede tridimensional de colágeno e adesivo formada não é totalmente impermeável ao longo da dentina desmineralizada. Ao contrário, a separação de fases não somente prejudica a formação de uma interface integrada de adesivo e fibrilas de colágeno, mas também restringe a penetração do sistema adesivo ao longo da extensão da dentina desmineralizada e da dentina subjacente ${ }^{156}$. As partículas de BisGMA, que tendem a se concentrar no topo da dentina desmineralizada, onde há menor quantidade de água, inibem a infiltração do adesivo 
na matriz desmineralizada subjacente. Além disso, devido à instabilidade das moléculas de HEMA em ambiente aquoso, haverá degradação das mesmas se expostas aos fluidos orais ${ }^{155}$.

A nanoinfiltração, outra interpretação da qualidade da interface adesiva em restaurações adesivas, foi avaliada através da imersão de dentes restaurados com sistemas adesivos em uma solução de nitrato de prata. Os íons de prata tendem a penetrar nos espaços interfibrilares, não ocupados por monômeros resinosos ${ }^{147}$. Esta técnica distingue-se dos tradicionais estudos de microinfiltração por permitir a observação de defeitos da interface mesmo na ausência de fendas, detectando espaços nanométricos de aproximadamente $0,02 \mu \mathrm{m}$. A nanoinfiltração ocorre principalmente na base da camada híbrida ${ }^{147}$ e no interior da mesma ${ }^{105}$, onde houver espaços para movimentação de fluidos. Posteriormente, outro estudo ${ }^{171}$ verificou que a maioria das uniões adesivas em esmalte não mostrou nanoinfiltração significativa, enquanto praticamente todas as uniões adesivas em dentina a apresentaram algum grau desse tipo de infiltração.

Os espaços nanométricos não permitem migração de bactérias, mas água, sais minerais, e enzimas bacterianas podem facilmente penetrar tais espaços ${ }^{41}$. A maior preocupação em relação à água nestes locais é de que pode haver um enfraquecimento das fibrilas de colágeno desprotegidas através de hidrólise ${ }^{111}$. Entretanto, a relevância da nanoinfiltração na longevidade de restaurações adesivas não foi completamente documentada até o momento, mas tem-se sugerido que ela pode ter um efeito negativo na qualidade das uniões adesivas ${ }^{109,181,186}$. Ainda, não há evidências que suportem a idéia do rompimento da ligações adesivas via hidrólise do sistema adesivo ${ }^{110}$ ou dos componentes protéicos (fibrilas de colágeno) da interface adesiva ${ }^{166}$, mas relatou-se ${ }^{135}$, recentemente, que a degradação da interface dentina-resina poderia ocorrer em três estágios. No primeiro, a água é absorvida no interior do polímero, iniciando-se a degradação química ${ }^{59}$; numa segunda, os monômeros são extraídos da camada híbrida ou da camada de adesivo ${ }^{73}$; na terceira fase as fibrilas de colágenos expostas seriam degradadas pela ação de metaloproteinases (MMPs) presentes na dentina ou na saliva ${ }^{34,} 74$. Destaca-se, ainda, o efeito da mastigação sobre a degradação das fibrilas de colágeno. A carga mastigatória pode produzir a fadiga do colágeno por deformação elástica das fibrilas 
e, eventualmente, deformações plásticas ${ }^{53}$. Assim, alongadas e deformadas, as fibrilas tornam-se mais vulneráveis à degradação, seja por hidrólise, pela ação de enzimas bacterianas ou pelas próprias MMPs.

WATSON et al. ${ }^{64,153}$ introduziram o termo "teste de micropermeabilidade" através da aplicação de corantes fluorescentes na câmara pulpar de dentes restaurados, in vitro, e avaliados por microscopia de fluorescência confocal. Dentre outras vantagens, a metodologia empregando microscopia confocal possibilita a utilização de corantes fluorescentes que, em pequenas concentrações, são inertes aos tecidos e aos sistemas adesivos ${ }^{191}$. Possibilita ainda a obtenção dos espécimes sem a necessidade de uma técnica complexa, comparada com a utilização de microscopia eletrônica de varredura ${ }^{128}$. Além disso, sua simplicidade reduz os riscos de ocorrência de artefatos de técnica. Através do teste de micropermeabilidade, os corantes fluorescentes, após serem aplicados na câmara pulpar, penetram nos túbulos dentinários em direção à interface adesiva, destacando a presença de porosidades ou fendas que resultaram da contração de polimerização dos monômeros contidos no primer, adesivo ou resina composta. Permite, ainda, a avaliação da extensão em que estes monômeros penetravam na dentina desmineralizada $^{189}$. Estudos em que se avaliou a micropermeabilidade em restaurações de resina composta revelaram importantes informações em relação à porosidade da interface adesiva, especialmente em espécimes aparentemente livres de fendas ${ }^{62}$.

Resultados obtidos através de microscopia de fluorescência foram correlacionados à nanoinfiltração e sugeriram possíveis "rotas" de permeabilidade na camada híbrida. A utilização de corantes fluorescentes que penetraram na intimidade da interface adesiva de restaurações de resina composta forneceram, também, suporte para a idéia de que o fenômeno da nanoinfiltração está relacionado ao procedimento adesivo propriamente dito e não com à fadiga da camada híbrida a longo prazo ${ }^{41}$. Por outro lado, durante a flexão de cúspides em dentes com restaurações adesivas promoveria absorção de água e o movimento de fluido na união entre a camada de adesivo e a camada híbrida. Outro estudo ${ }^{148}$ utilizando corantes fluorescentes, observou-se que a termociclagem de dentes que receberam restaurações adesivas pode promover degradação mecânica e química das uniões 
adesivas, acelerando a remoção de monômeros residuais. Observou-se, ainda, a ocorrência de "nano-canais" no interior da interface adesiva, resultados sugestivos de que a camada híbrida poderia se comportar como uma membrana permeável ${ }^{171}$. Isto implica em que pode haver movimentação de fluidos em ambas direções. A presença de água nestes canais deve contribuir diretamente para degradação do sistema adesivo, causando a extração de monômeros residuais não polimerizados e oligômeros a longo prazo ${ }^{71}$.

Há mais de 20 anos NAKABAYASHI et al $^{98}$ já afirmavam que a camada híbrida seria formada pela permeação de monômeros resinosos que seriam polimerizados na intimidade do substrato dentinário. Esta afirmação convencionou o pensamento de que um perfeito selamento poderia ser estabelecido se os túbulos dentinários e os espaços no interior da matriz de colágeno fossem completamente infiltrados pelo sistema adesivo. Esta concepção é baseada no fato de que o adesivo seria impermeável à movimentação de fluidos ${ }^{167}$. Uma maior ou menor permeabilidade da camada híbrida vai depender não somente de uma correta aplicação do sistema adesivo, mas também, de uma efetiva polimerização deste material. Mais informações são necessárias sobre o grau de conversão de monômeros e formação de ligações cruzadas nos sistemas adesivos, já que os mesmos são polimerizados em ambiente úmido quando aplicados in vivo ${ }^{152}$. Da mesma forma, como ocorre com as resinas compostas, pode haver um efeito plastificador da água sobre o polímero formado se houver uma insuficiente polimerização do sistema adesivo na formação da camada híbrida ${ }^{49}$. Geralmente, o sistema adesivo tem propriedades mecânicas favoráveis quando eles são adequadamente polimerizados ${ }^{91}$. Como o processo de fotoativação está relacionado à utilização de uma fonte de luz fotoativadora, diferentes densidades de potência, bem como o espectro de irradiância que estes aparelhos emitem devem influenciar decisivamente a cinética da conversão de monômeros nos sistemas adesivos. Ainda não se observaram na literatura odontológica as conseqüências da fotoativação com diferentes fontes de luz em relação à conversão de monômeros, propriedades mecânicas e ainda sobre a permeabilidade da camada híbrida formada. Em tese, a utilização de fontes de luz fotoativadoras com alta densidade de potência em curto tempo de exposição estaria justificado, uma vez que os sistemas adesivos permitem 
a passagem da luz facilmente por serem aplicados em camadas bem finas ${ }^{29}$. Entretanto, pela natureza líquida dos sistemas adesivos, há possibilidade da formação de uma camada superficial de inibição pela facilidade com que reagem com o oxigênio ${ }^{142}$. Esta reação será reversível somente pela ação da luz fotoativadora, que intensificará a capacidade de reação dos radicais da canforoquinona com as moléculas de monômero.

Uma densidade de potência de $400 \mathrm{~mW} / \mathrm{cm}^{2}$ foi padronizada empiricamente para a fotoativação da maioria das resinas compostas e sistemas adesivos ${ }^{28}$. Utilizando-se diferentes densidades de potência (entre 200 a $800 \mathrm{~mW} / \mathrm{cm}^{2}$ ), verificou-se que não houve diferença estatística na conversão de monômeros do sistema adesivo One Step (Bisco). Somente com densidade de potência de 100 $\mathrm{mW} / \mathrm{cm}^{2}$ é que ocorreram valores significantemente menores de conversão ${ }^{28}$. Além disso, poucos trabalhos são encontrados na literatura em relação à cinética de conversão de monômeros em sistemas adesivos e a sua possível correlação com a integridade da interface e com a resistência adesiva. Outro fato a ser mencionado é que os sistemas adesivos convencionais de dois ou três passos apresentam um gradiente de concentração de monômeros polimerizados em direção à profundidade de dentina desmineralizada e aos túbulos dentinários ${ }^{109,}{ }^{157}$. Para os sistemas adesivos autocondicionantes, teoricamente tais regiões não deveriam existir, uma vez que o processo de condicionamento e permeação do primer ocorrem simultaneamente com a aplicação dos mesmos monômeros acídicos ${ }^{171}$. A possibilidade de monômeros residuais ou de solventes na base da camada híbrida ou em tags de resina causaria, dependendo da magnitude, uma maior porosidade nestas estruturas, reduzindo a longevidade das restaurações adesivas e causando irritações pulpares ${ }^{49}$.

Em que pese a importância dos fatores relacionados à resina composta, principalmente a contração de polimerização, e aqueles relativos aos sistemas adesivos tornou-se evidente o papel da luz fotoativadora na longevidade de restaurações adesivas. Desta forma o presente trabalho tem a proposta de avaliar, in vitro, a resistência de união adesiva e a micromorfologia da interface adesiva de restaurações de resina composta, utilizando diferentes aparelhos de luz fotoativadora para polimerizar um sistema restaurador adesivo. 
2-Revisão de Literatura 


\section{2- Revisão de Literatura}

\section{1- Cinética de Conversão}

RUEGGEBERG; CRAIG $^{140}$, em 1988, avaliaram a sensibilidade das diferentes metodologias para detectar possíveis diferenças em espécimes polimerizados através da adição de novas camadas de resina sobre um espécime de resina pré-polimerizada. As metodologias avaliadas foram conversão de monômeros, bem como teste de microdureza, absorção de água e liberação de monômeros residuais utilizando-se resinas comerciais. Para a análise dos parâmetros de conversão foi utilizado um espectrofotômetro de raios infravermelho (FT-IR). Os autores, baseados nos resultados obtidos, observaram uma maior sensibilidade para detectar alterações em espécimes polimerizados em diferentes espessuras quando utilizaram a conversão com o FT-IR e também o teste de dureza dos materiais. O teste de liberação de monômeros residuais apresentou uma sensibilidade mediana e a absorção de água, nenhuma sensibilidade. Assim, a detecção das diferenças entre espécimes avaliados com FT-IR mostrou ser mais sensível em relação às diferenças na conversão nos espécimes com diferentes espessuras, seguido do teste de dureza Knoop, teste de liberação e por último o de absorção de água. A absorção de água não variou nos diferentes espécimes, mesmo quando houve variação no grau de conversão.

REES; JACOBSEN ${ }^{133}$, em 1989, baseando-se no conceito de que a contração volumétrica se deve à formação de ligações covalentes próximas entre as unidades monoméricas da resina composta, que pode levar à formação de fendas marginais, propuseram mensurar a resultante das forças de contração em cinco marcas comerciais de resina composta. Desta forma, selecionaram-se as resinas quimicamente ativadas e fotoativáveis: Heliomolar, Oclusin, P30 para dentes posteriores e, ainda, as resinas Aurafill, Concise e Silar para anteriores. A contração de polimerização foi avaliada por meio de um dilatômetro. Da análise dos resultados, verificou-se que a resina fotoativada Aurafill apresentou a maior porcentagem de contração $(2,24 \%)$, enquanto que as resinas quimicamente ativadas Concise e Silar, as menores $(1,18 \%$ e $1,10 \%)$. As resinas Occlusin e P30 apresentaram valores 
relativamente baixos $(1,16 \%$ e 0,9 \%), o que foi atribuído a um menor conteúdo de matriz orgânica e maior quantidade de partículas inorgânicas. Ocorreram menores porcentagens de contração nas resinas Heliomolar e Silar devido à presença de monômeros pré-polimerizados, aliado à presença de um maior conteúdo de partículas inorgânicas. Verificaram ainda que a maior porcentagem de contração ocorreu nos primeiros sessenta minutos após o início da polimerização. Os autores afirmaram ainda que o peso molecular e os diferentes monômeros presentes nos diferentes materiais restauradores podem também ter influenciado nos resultados.

Em busca de uma melhor adaptação marginal da resina composta à estrutura dentária, através de um método que permitisse um melhor escoamento do material durante sua polimerização, UNO; ASMUSSEN ${ }^{178}$, em 1991, investigaram o efeito da fotoativação com baixa intensidade de luz na adaptação marginal da resina composta em cavidades localizadas em dentina. Após o desgaste das superfícies vestibulares e linguais, cavidades cilíndricas foram confeccionadas na dentina de molares humanos extraídos. Em seguida, os preparos foram restaurados com resina composta (Silux Plus), aplicada em incremento único e a superfície do material restaurador foi coberta com uma matriz, para que a fotoativação fosse realizada. Um transformador foi acoplado ao aparelho fotoativador para permitir a redução da intensidade de luz ao nível desejado, reduzindo-se assim, a velocidade de polimerização da resina composta. Os grupos foram divididos, considerando-se que cinco cavidades foram confeccionadas para cada condição a ser testada: 1 - $220 \mathrm{~V}$ a 60 segundos (baseline 1); 2- $220 \mathrm{~V}$ a 30 segundos (baseline 2); grupo A - $110 \mathrm{~V}$ por 5 segundos / OV por 25 segundos/ $220 \mathrm{~V}$ por 30 segundos; grupo B-110 V por 10 segundos/ $0 \mathrm{~V}$ por 20 segundos/ $220 \mathrm{~V}$ por 30 segundos; grupo C - $110 \mathrm{~V}$ por 20 segundos/ $0 \mathrm{~V}$ por 10 segundos/ $220 \mathrm{~V}$ por 30 segundos; grupo D- $110 \mathrm{~V}$ por 30 segundos/ $220 \mathrm{~V}$ por 30 segundos; grupo E - $110 \mathrm{~V}$ por 60 segundos. Observou-se que quando a resina composta foi irradiada por $30 \mathrm{~s}$ a $110 \mathrm{~V}$, seguida de 30 segundos a $220 \mathrm{~V}$, a adaptação marginal mostrou-se significativamente melhor, com redução na largura e extensão das fendas marginais. Porém, um melhor grau de adaptação foi obtido no grupo E, o qual utilizou somente baixa intensidade de luz. Isto resultou em valores aceitáveis de resistência adesiva à dentina, mediante testes também realizados neste estudo. Os autores concluíram que uma pré-polimerização 
do material com baixa intensidade de luz, seguida da intensidade máxima, permite maior escoamento e diminuição da tensão de contração do mesmo, resultando em uma melhor adaptação marginal.

Em 1993, RUEGGEBERG et al. ${ }^{139}$ propuseram listar e ordenar as variáveis mais relevantes na maximização da polimerização de resinas compostas, para que um melhor tempo de exposição fosse utilizado em termos clínicos. Desta forma, estes autores propuseram avaliar simultaneamente o impacto relativo do tipo de partícula inorgânica (híbrida ou micropartículas), da cor (universal ou cinza), tempo de exposição (20, 40, 60 e 80 segundos) e densidade de potência $(800,578,400$ e $233 \mathrm{~mW} / \mathrm{cm}^{2}$ ) em restaurações simuladas. As marcas comerciais selecionadas foram a P50 e Silux Plus, que foram utilizadas em diferentes espessuras. Da análise dos resultados, os autores verificaram que na superfície das resinas fotoativadas o tipo de partícula, o tempo de exposição e a cor da resina foram os parâmetros mais importantes. Quando se avaliou a $1 \mathrm{~mm}$ de profundidade, o tempo de exposição, o tipo de partícula e a intensidade de luz foram os parâmetros mais relevantes, nesta ordem. A $2 \mathrm{~mm}$ ou mais de profundidade, os fatores como densidade de potência e tempo de exposição foram os mais predominantes. A cor da resina e o tipo de partícula inorgânica exerceram mínima influência nas camadas mais profundas.

RETIEF $^{136}$, em 1994, relatou que todas as resinas compostas sofrem contração de polimerização, resultando em forças de tensão na interface denterestauração. Citou que as propriedades da resina composta, a contração de polimerização, os diferentes coeficientes de expansão térmica entre o dente e a restauração e a absorção de água determinam a dimensão da fenda e da microinfiltração nas restaurações de resina composta. O tamanho da cavidade também exerce significante influência na dimensão da fenda marginal. $O$ autor afirmou que nenhum sistema adesivo é capaz de eliminar completamente a microinfiltração e que as forças mastigatórias contribuem para o aumento da mesma. Entretanto, a infiltração marginal pode ser minimizada com a inserção da resina composta pela técnica incremental, bem como com o prolongamento para os procedimentos de acabamento e polimento, o que favorece a expansão higroscópica, permitindo uma melhor adaptação marginal. 
Em 1994, RUEGGEBERG; CAUGHMAN; CURTIS $^{138}$ propuseram-se a estudar o impacto de várias intensidades de luz e a duração do tempo de exposição sobre a polimerização da resina composta em diferentes profundidades (superfície, 1 mm, $2 \mathrm{~mm}, 3 \mathrm{~mm}$ ). Os tempos de exposição foram de 20, 40, 60 e 80 segundos e a densidade de potência máxima foi de $800 \mathrm{~mW} / \mathrm{cm}^{2}$, sendo que filtros foram utilizados para minimizar a intensidade de luz para que se utilizassem as densidades de 587 $\mathrm{mW} / \mathrm{cm}^{2}, 400 \mathrm{~mW} / \mathrm{cm}^{2}$ e $233 \mathrm{~mW} / \mathrm{cm}^{2}$. Foram utilizadas duas resinas compostas (P50 e Silux Plus) em dois matizes (universal e cinza). Os resultados indicaram que na superfície a polimerização não foi grandemente afetada, nem pelo tempo de exposição nem pela intensidade de luz. Em profundidades maiores que $2 \mathrm{~mm}$, ocorreu inadequada polimerização do material. Observaram ainda que a polimerização é muito susceptível às mudanças da intensidade de luz e do tempo de exposição. De acordo com os autores, um tempo de exposição de 60 segundos e uma intensidade mínima de $400 \mathrm{~mW} / \mathrm{cm}^{2}$ de luz são recomendados para a polimerização da resina composta, não devendo ser utilizadas intensidades inferiores a $233 \mathrm{~mW} / \mathrm{cm}^{2}$. A espessura das camadas de resina composta não deve exceder $2 \mathrm{~mm}$, sendo $1 \mathrm{~mm}$ o ideal para uma adequada polimerização do material.

Em 1995, procurando abordar os fatores importantes para a obtenção de uma adequada polimerização do material, CAUGHMAN; RUEGGEBERG; CURTIS ${ }^{20}$ realizaram uma revisão de literatura com o intuito de avaliar os vários fatores que podem afetar a polimerização dos compósitos quando se utiliza aparelho de luz com lâmpada halógena. Os autores recomendaram a utilização de aparelhos fotoativadores de qualidade e que os mesmos deveriam ser avaliados periodicamente, em termos de intensidade de luz. Sugeriram que a intensidade de luz deve ser aferida com a utilização de radiômetro e que a intensidade mínima aceitável seria compreendida entre $280 \mathrm{~mW} / \mathrm{cm}^{2}$ e $300 \mathrm{~mW} / \mathrm{cm}^{2}$. Para isso, é importante que os profissionais estejam atentos aos sinais de degradação do bulbo, refletor e da fibra óptica do aparelho. Adicionalmente, a resina composta seria um fator a ser considerado, uma vez que partículas de carga entre 0,01 a 1,0 $\mu \mathrm{m}$ reduzem a penetração de luz devido à dispersão, assim como o emprego de matizes mais escuras, as quais devem afetar negativamente a transmissão de luz. Comentaram ainda que cada incremento de resina composta não deve ultrapassar 2 
$\mathrm{mm}$ de espessura e que a distância entre a ponta ativa do aparelho e a superfície da resina pode ser de até $6 \mathrm{~mm}$, se pelo menos 60 segundos de exposição são utilizados.

A proposta de UNTERBRINK; MUESSNER ${ }^{179}$, em 1995, foi avaliar o efeito de diferentes intensidades de luz na formação de fendas marginais, no desenvolvimento do módulo, da resistência flexural e, ainda, na profundidade de polimerização de dois sistemas restauradores. As cavidades foram confeccionadas na vestibular de 48 incisivos bovinos com margens em dentina, os quais foram divididos de acordo com os diferentes procedimentos restauradores e intensidades de luz: 1- Syntac/ Tetric/ $250 \mathrm{~mW} / \mathrm{cm}^{2}$; 2- Syntac/ Tetric/ $450 \mathrm{~mW} / \mathrm{cm}^{2}$; 3Scotchbond MP/ Tetric/ $250 \mathrm{~mW} / \mathrm{cm}^{2}$; 4- Scotchbond MP/ Tetric/ $450 \mathrm{~mW} / \mathrm{cm}^{2}$; 5Syntac/ Z100/ $250 \mathrm{~mW} / \mathrm{cm}^{2}$; 6- Syntac/ Z100/ $450 \mathrm{~mW} / \mathrm{cm}^{2} ; 7$ - Scotchbond MP/ $\mathrm{Z} 100 / 250 \mathrm{~mW} / \mathrm{cm}^{2} ; 8-$ Scotchbond MP/ Z100/ $450 \mathrm{~mW} / \mathrm{cm}^{2}$. Em todos os grupos, a resina composta foi inserida em incremento único e fotoativada por 40 segundos. A análise marginal mostrou que a resina composta Z100, quando utilizada tanto com o Scotchbond MP quanto com o Syntac, apresentou maior formação de fenda marginal quando fotoativada com alta intensidade de luz. A resina Tetric revelou melhor adaptação marginal, comparada a Z100, quando utilizada com ambos os sistemas adesivos e com ambas as intensidades de luz. A resistência e o módulo flexural de ambas as resinas compostas foram inferiores quando fotoativadas com baixa intensidade de luz, após 30 minutos e 24 horas. Diferenças não foram encontradas na contração volumétrica ou profundidade de polimerização, relacionada ao método de fotoativação para os dois materiais testados. Em um tempo de fotoativação de 40 segundos, os materiais foram igualmente polimerizados a uma profundidade de 4,5 $\mathrm{mm}$, independente da intensidade de luz utilizada. Concluiu-se que a utilização de alta intensidade de luz pode ocasionar inferior integridade marginal, devido a maior tensão de contração gerada, e que o desenvolvimento do módulo de elasticidade pode ser influenciado pela intensidade de luz.

Considerando-se que a intensidade de luz e o tempo de exposição constituem fatores importantes para um adequado grau de conversão da resina composta e, conseqüentemente, para a longevidade da restauração, FEILZER et al ${ }^{47}$ avaliaram, em 1995, a influência da intensidade de luz na integridade da interface adesiva de 
restaurações de resina composta em cavidades de classe V. Este estudo também avaliou a influência da intensidade de luz na contração de polimerização e o efeito da utilização de uma camada intermediária elástica. Vinte e quatro pré-molares e caninos humanos receberam preparos classe $\mathrm{V}$ nas superfícies vestibulares $\mathrm{e}$ linguais, com margens cervicais localizadas abaixo da junção amelo-cementária. Os dentes foram divididos em 3 grupos: 1- sistema adesivo/ camada intermediária (Protect Liner)/ resina composta; 2- sistema adesivo/ resina composta; 3- sistema adesivo/ camada intermediária (Protect Liner) como material restaurador. Para cada grupo, metade dos espécimes foi fotoativada com intensidade de luz de $250 \mathrm{~mW} / \mathrm{cm}^{2}$ e metade com $650 \mathrm{~mW} / \mathrm{cm}^{2}$. Após a ciclagem térmica (400 ciclos; 15 a $65^{\circ} \mathrm{C}$ ), os espécimes foram seccionados no sentido vestíbulo-lingual e impressões foram feitas para a análise de réplicas em MEV. Os resultados mostraram continuidade aceitável na interface adesiva para ambas as intensidades utilizadas. Contudo, a utilização de baixa intensidade de luz mostrou-se significativamente melhor para a integridade marginal quando comparada à alta intensidade. Segundo os autores, isto se deve à extensão do estado visco-elástico e à conseqüente redução do desenvolvimento das tensões de contração. Diferenças estatísticas não foram encontradas entre os grupos, pois a presença da camada intermediária elástica entre a parede cavitária e a resina composta (grupo 1), ou a restauração realizada com este material (grupo 3), não influenciou na integridade marginal obtida. A contração de polimerização para as duas condições analisadas foi similar, sugerindo semelhante grau de conversão e propriedades dos materiais. Concluíram que a utilização de baixa intensidade de luz, ao contrário da alta intensidade, contribui para uma melhor integridade marginal em restaurações realizadas em cavidades de classe $\mathrm{V}$.

CARVALHO et al. ${ }^{18}$, em 1996, revisaram os fatores relacionados à realização de restaurações com resina composta, já que a aplicação clínica destes materiais restauradores pode interferir na qualidade da união adesiva. Desta forma, analisaram os fatores relacionados à contração de polimerização e à maneira pela qual pode-se obter um relaxamento das tensões provenientes desta contração. Os autores falaram inicialmente sobre o fator de configuração cavitária, afirmando que o relaxamento das tensões está em função da deformação elástica do material e do escoamento para as superfícies livres. Destacaram que quando se aplica resina 
composta em cavidades de classe $\mathrm{V}$ superficiais ocorre um adequado alívio das tensões pela adequada área livre presente neste tipo de cavidade, diferente das cavidades tipo caixa, em que ocorre uma área maior de superfície aderida. Os autores ainda mencionaram que utilizando-se resinas compostas quimicamente ativadas, possibilitaria um tempo maior para que se aliviassem as resultantes das forças de contração, comparado à utilização de resinas compostas fotoativáveis. Afirmou-se ainda que, quanto maior a concentração de matriz orgânica na composição de uma resina composta, maior a absorção de água, o que compensaria parcialmente a contração de polimerização. Descreveram-se também as diferentes formas para que haja o alívio das tensões geradas durante o processo de contração. Inicialmente, mencionaram a necessidade do desenvolvimento de sistemas adesivos que possibilitassem uma maior resistência adesiva capaz de superar a resultante das forças de contração, idealmente de mesma magnitude da obtida quando em esmalte. Além disso, sugeriu-se a aplicação de um material elástico na base da cavidade com o intuito de absorver as tensões geradas não somente durante a polimerização da resina composta, mas também pelos esforços mastigatórios. Os autores mencionaram ainda que a aplicação do material restaurador em incrementos de menor volume promoveria a obtenção de uma maior área livre para o alívio das tensões. Concluíram assim que o sucesso clínico das restaurações de resina composta seria baseado na compreensão dos diferentes aspectos relacionados aos fatores previamente discutidos.

Um método alternativo de polimerização é a modulação da intensidade de luz que polimeriza a resina composta, o que parece permitir um melhor escoamento do material, resultando em uma melhor adaptação marginal. GORACCI; MORI; CASA DE MARTINIS ${ }^{61}$, em 1996, compararam a adaptação da resina composta à dentina após a fotoativação do material de forma convencional e gradual. Cavidades classe $\checkmark$ foram confeccionadas em pré-molares humanos extraídos e restauradas com o sistema adesivo Scotchbond Multi-Purpose e a resina composta Z100, a qual foi aplicada de forma incremental. No primeiro grupo $(A)$, todas as camadas foram fotoativadas pela técnica convencional (40 segundos a $250 \mathrm{~mW} / \mathrm{cm}^{2}$ ), enquanto que, no segundo grupo (B), foi utilizada a técnica de fotoativação gradual na camada superficial da resina. Para isso, um aparelho regulador foi adicionado ao 
convencional para permitir o aumento gradual da intensidade de luz emitida em uma faixa de 30 a $250 \mathrm{~mW} / \mathrm{cm}^{2}$ em 4 minutos. Posteriormente, réplicas de resina foram confeccionadas para serem observadas através de MEV. O grupo A não apresentou fendas na interface esmalte-resina, porém o exame da interface dentina-resina revelou a presença de fendas de aproximadamente $10 \mu \mathrm{m}$. Este resultado deve-se à contração proveniente da polimerização iniciada pela fotoativação convencional, que gerou tensão concentrada nas áreas de união mais frágeis. Em contraste, nos espécimes em que a primeira camada de resina foi polimerizada gradualmente $(B)$, uma continuidade estrutural foi observada entre o material restaurador e a dentina. Assim, a tensão gerada pela contração não foi suficiente para romper as ligações adesivas entre material restaurador e estrutura dentária. Os autores concluíram que é possível melhorar a adaptação das resinas compostas à superfície dentinária através da redução na velocidade de polimerização, representando, desta forma, uma solução aos problemas de adesão em restaurações de resina composta.

Através de uma revisão de literatura, DAVIDSON; FEILZER ${ }^{32}$, em 1997, discutiram os problemas relacionados com a contração de polimerização dos materiais e a tensão gerada. Relataram que a contração ocorre durante a polimerização das resinas compostas e dos cimentos de ionômero de vidro, porém seus efeitos podem ser minimizados mediante a utilização de bases cavitárias e pela modulação da fotoativação. Adicionalmente, existe uma relação direta entre fator $\mathrm{C}$ e desenvolvimento das tensões, ou seja, quanto maior esse fator, maior o desenvolvimento das tensões da contração. Comentaram que o emprego de uma base cavitária com um material de baixo módulo de elasticidade, como o cimento de ionômero de vidro, contribuiria para a distribuição mais homogênea dessas tensões. Também, a redução da intensidade de luz inicial proporcionaria uma lenta reação de polimerização do material, permitindo um melhor escoamento do mesmo e, conseqüentemente, uma melhor integridade marginal. Os autores concluíram que é importante o conhecimento dos problemas relacionados à contração de polimerização, com o intuito de buscar técnicas que minimizem os efeitos por ela gerados.

A influência da intensidade de luz e a variação no tempo de irradiação na eficácia da polimerização de dois tipos de resina composta foram avaliadas por 
DAVIDSON-KABAN et al. ${ }^{33}$, em 1997. Verificou-se ainda o efeito da intensidade reduzida de luz na preservação da adaptação interna às paredes da cavidade. Neste estudo, foram utilizadas as resinas compostas de micropartículas (Silux Plus) e a híbrida (P50). Para a avaliação da adaptação interna, foram realizadas cavidades de classe $\mathrm{V}$ em dentes bovinos, localizadas em dentina. Os materiais restauradores foram fotoativados com duas densidades de potência: $700 \mathrm{~mW} / \mathrm{cm}^{2}$ por 60 segundos e 10 segundos e a $175 \mathrm{~mW} / \mathrm{cm}^{2}$ por 60 segundos. Após 24 horas de armazenamento, os procedimentos de acabamento e polimento foram realizados e os espécimes seccionados vestíbulo-lingualmente através da restauração. Obtiveram-se réplicas que foram analisadas em MEV. Pela análise dos resultados, observou-se que não houve diferença estatística na adaptação interna entre os dois tipos de resinas compostas utilizadas. Para a resina microparticulada, houve um número significativamente maior de defeitos visíveis quando se utilizou uma densidade de potência de $700 \mathrm{~mW} / \mathrm{cm}^{2}$, quando comparada a uma densidade de $175 \mathrm{~mW} / \mathrm{cm}^{2}$ em um tempo de irradiação de 60 segundos. Quando se alterou o tempo de exposição de $60 \mathrm{~s}$ para $10 \mathrm{~s}$, houve uma diminuição significante no número de defeitos visíveis para a resina híbrida, mas não para a de micropartículas. Além disso, observou-se que, quando se reduziu a densidade de potência, houve um menor grau de conversão dos monômeros, mas, apesar disto, foi possível se obter boas propriedades mecânicas e uma boa adaptação às paredes da cavidade.

KORAN; KURSCHNER ${ }^{92}$, em 1998, propuseram-se a avaliar comparativamente o desenvolvimento, grau e profundidade de polimerização, a contração, viscosidade e dureza de superfície de uma resina composta, quando fotoativada através de duas técnicas. A primeira delas compreendeu a técnica de dois passos, sendo que as densidades de potência utilizadas foram: grupo 1 - 150 $\mathrm{mW} / \mathrm{cm}^{2}$ por 10 segundos $+500 \mathrm{~mW} / \mathrm{cm}^{2}$ por mais 30 segundos $\left(16.500 \mathrm{~mJ} / \mathrm{cm}^{2}\right)$; grupo $2-150 \mathrm{~mW} / \mathrm{cm}^{2}$ por 10 segundos $+700 \mathrm{~mW} / \mathrm{cm}^{2}$ por mais 30 segundos $\left(22.500 \mathrm{~mJ} / \mathrm{cm}^{2}\right)$. Nos demais grupos foi utilizada a técnica de fotoativação convencional: grupo $3-500 \mathrm{~mW} / \mathrm{cm}^{2}$ por 40 segundos $\left(20.000 \mathrm{~mJ} / \mathrm{cm}^{2}\right)$; grupo 4 $700 \mathrm{~mW} / \mathrm{cm}^{2}$ por 40 segundos $\left(28.000 \mathrm{~mJ} / \mathrm{cm}^{2}\right)$. Os dados obtidos em cada um dos testes foram analisados estatisticamente. Verificou-se que, quando se utilizou a técnica em dois passos, não houve diferença estatística em relação à contração de 
polimerização, à dureza de superfície ou na concentração de monômeros residuais, quando comparada à técnica convencional. Quanto ao teste de resistência adesiva (cisalhamento), observaram-se maiores valores quando se utilizou a técnica de fotoativação por dois passos. Os menores valores de resistência adesiva foram apresentados pelo grupo que utilizou maior densidade de potência (grupo 4). Sendo assim, os autores concluíram que o escoamento do material é maior quando se utilizou uma redução inicial da densidade de potência, que contribuiu para a redução da tensão de contração na cavidade durante o processo de polimerização. Desta forma, afirmaram que, clinicamente, ao se fotoativar o material restaurador utilizando a técnica por dois passos, esta deverá contribuir de forma significativa para uma melhor adaptação marginal.

O vetor de contração das resinas química e fotoativadas e, em particular, a afirmação de que as resinas compostas contraem em direção à luz, foram analisados por VERSLUIS; TANTBIROJN; DOUGLAS ${ }^{185}$, em 1998. Através da análise por elemento finito, os autores observaram que a contração de polimerização não se baseou na teoria de que os vetores de contração são direcionados para o centro do material (resinas químicas) ou para a fonte de luz (fotoativáveis). Desta forma, a direção de contração não foi significativamente afetada pelo direcionamento da fonte de luz, mas determinada pela adesão da restauração à estrutura dentária e pelas superfícies livres. Nas resinas quimicamente e fotoativadas, a contração de polimerização ocorreu em direção ao centro da massa somente quando não se realizaram os procedimentos adesivos. Quando estes procedimentos foram realizados, a contração se dava em direção às superfícies aderidas, mudando-se os vetores de contração. Conseqüentemente, diferenças entre os padrões de contração das resinas auto e fotoativadas foram mínimos. Concluiu-se que as resinas compostas não se contraem em direção à luz, mas esta direção é predominantemente determinada pelo formato cavitário e pela qualidade da adesão. A direção dos vetores de contração, em resposta ao posicionamento da luz, não parece ser um critério apropriado para otimizar a qualidade marginal.

No mesmo ano, SAKAGUCHI; BERGE ${ }^{144}$ avaliaram a relação entre a densidade de potência com a tensão de contração de polimerização pós-gel e com o grau de conversão de resinas compostas. Para isso, os autores confeccionaram 
espécimes cilíndricos de resina composta que foram polimerizados a uma distância de $7 \mathrm{~mm}$, com tempo de exposição de 40 segundos e intensidades atenuadas de luz: i-71 \%; ii- 49 \%; iii- 34 \%. Compararam-se ainda os resultados a um grupo (iv) em que se utilizou reduzida intensidade de luz inicial (71\% por 20 segundos) seguida de densidade de potência máxima (100\% por 20 segundos). Um grupo que foi polimerizado com intensidade máxima por 40 segundos serviu como controle (v). O grau de conversão (DC) foi medido na superfície e na base dos espécimes, além da tensão de contração de polimerização pós-gel que foi feita na base dos mesmos. Os resultados mostraram que houve diferença significante no DC entre os grupos, com exceção dos grupos que tiveram uma atenuação da intensidade de 71 e 49 \%. Quando se avaliou a base dos espécimes, não houve diferença significante entre os resultados de DC dos grupos com atenuação de 71 \% e com densidade de potência máxima (100\%). Nos demais, houve diferença entre todos os grupos experimentais. O grupo iv não apresentou diferença significante em relação aos demais grupos. Este grupo ainda apresentou uma redução de 21,8 \% da contração de polimerização pós-gel. Os autores concluíram que a aplicação de uma densidade de potência com menor intensidade do que a máxima resultou em redução da contração de polimerização pós-gel, sem que afetasse significantemente o DC da resina avaliada.

Considerando a hipótese que a fotoativação com uma baixa densidade de potência inicial poderia ser um método eficiente para reduzir as tensões nas margens localizadas em esmalte, KANCA; SUH ${ }^{87}$, em 1999, investigaram o efeito da fotoativação por pulso na redução do estresse de uma resina composta, com margens localizadas em esmalte. Este estudo examinou a dureza superficial, resistência à tração diametral e os efeitos dos estresses de polimerização foram avaliados através da penetração do corante em cavidades de classe I $(C=5)$. Os preparos foram realizados em 30 molares humanos extraídos, os quais foram restaurados com resina composta $Z 100$ pela técnica incremental (2 mm). O incremento oclusal foi fotoativado através de diferentes densidades de potência e intervalos de tempo: grupo $1-40$ segundos a $600 \mathrm{~mW} / \mathrm{cm}^{2}$; grupo 2- 40 segundos a $100 \mathrm{~mW} / \mathrm{cm}^{2}$; grupo 3- 2 segundos a $300 \mathrm{~mW} / \mathrm{cm}^{2}+5$ minutos espera $+10 \mathrm{~s}$ a 600 $\mathrm{mW} / \mathrm{cm}^{2}$. Posteriormente, os dentes foram imersos na fucsina básica a 0,5\% por 24 horas e seccionados para a avaliação da penetração do corante na interface 
esmalte-restauração. A dureza superficial do grupo 3 mostrou-se baixa e a resistência à tração diametral não apresentou diferenças significantes entre os grupos. A utilização da baixa densidade de potência resultou em significante menor penetração do corante, porém mínima infiltração foi observada no grupo que utilizou a fotoativação por pulso, acreditando-se ser o resultado de um melhor escoamento da resina composta, devido ao prolongamento do período pré-gel. Concluíram que a técnica de fotoativação por pulso pode ser importante na redução do estresse de restaurações com margens localizadas em esmalte.

RUEGGEBERG ${ }^{137}$ em 1999, com o intuito de esclarecer os tipos de aparelho fotoativadores que eram comercializados no mercado, descreveu detalhadamente os fatores relacionados ao entendimento do processo de polimerização. Este utiliza luz azul como ativador da canforoquinona, caracterizado por absorver luz na faixa de 450 a 500 nm quando se torna reativo, sendo que a adição de grupamentos amina acelera o processo pela formação de radicais livres. Descreveu-se ainda o processo pelo qual ocorre o processo de polimerização e a relação com a intensidade de luz, sendo que quanto maior a quantidade de fótons atingindo a resina composta, maior o número de radicais livres, sendo que a densidade de potência seria o fator chave para a porcentagem de conversão de monômeros e a velocidade (taxa) com que ocorre a conversão. Além disso, descreveu-se o conceito de profundidade de polimerização devido à atenuação da luz que ocorre em direção à profundidade do material pela absorção e dispersão de luz, sendo que cerca de $50 \%$ de energia se perde numa espessura de 0,5 mm em uma resina composta de cor A2. Descreveuse ainda o conceito de densidade de energia, que corresponde ao produto da densidade de potência pelo tempo de exposição. Este conceito está fundamentado na idéia de que a polimerização seria baseada na energia total aplicada à resina composta. Desta forma, idealmente os fabricantes poderiam mencionar a quantidade de energia necessária para polimerizar a resina composta, mas a densidade de energia dos aparelhos deveria ser monitorada pela redução da intensidade ao longo do tempo quando se tratam de aparelhos com lâmpada halógena. Mencionou-se que os clínicos estão enfrentando problemas, devido ao fato de que nem todos os aparelhos fotoativadores são capazes de polimerizar as diferentes marcas comerciais de resina, por conterem diferentes fotoiniciadores que não a 
canforoquinona. Assim, descreveram-se as diferentes fontes de luz fotoativadoras. A fonte de luz com lâmpada halógena corresponde ao mais comumente utilizado aparelho, apresentando um amplo espetro de luz com variada densidade de potência, que se reduz ao longo do tempo. O aparelho com arco de plasma foi lançado no mercado no início dos anos 90 e apresenta uma altíssima densidade de potência com amplo espectro, inclusive na região de ultravioleta e infravermelho, sendo que filtros são utilizados para permitir emissão na região visível do espectro. Descreveu-se ainda a utilização de aparelho com laser com intuito de fotoativar resinas compostas. Concluiu-se que o aparelho ideal a se utilizar para a polimerização de uma resina composta permanece ainda sem esclarecimento, sendo que estudos são necessários para a avaliação da qualidade e durabilidade dos polímeros formados, a integridade da interface marginal e ainda o impacto das altas temperaturas geradas com os diferentes aparelhos em termos de resposta pulpar.

Em uma revisão de literatura realizada por DAVIDSON; DE GEE ${ }^{29}$, em 2000, comentaram que a ativação da canforoquinona, o iniciador mais comumente presente nas resinas compostas, é de suma importância para o início da reação de polimerização do material, desde que a irradiação seja feita em um comprimento de onda de $470 \mathrm{~nm}$. No entanto, para uma adequada conversão da resina é necessária uma certa quantidade de energia, a qual pode ser aplicada de diferentes formas, sendo dependente das características da fonte de luz e da duração da exposição. Uma completa conversão pode não ser possível nas áreas mais profundas da restauração, principalmente se aparecerem defeitos em algum componente da lâmpada, risco que pode ser minimizado prolongando-se o tempo de exposição à luz. Enfatizaram que a conversão da resina composta está sempre associada à contração do material, contudo, uma forma de moderar as tensões provenientes da mesma é a utilização da fotoativação com baixa seguida de alta intensidade de luz, cuja técnica pode ser aplicada com recentes aparelhos fotoativadores existentes no mercado, como o Elipar (Espe) e o VIP (Bisco). Fontes de luz arco de plasma, como o Apollo 95E, também são citadas por irradiarem alta intensidade de luz contínua, em um estreito comprimento de onda e por um curto tempo de exposição. O emprego de alta intensidade de luz inicial gera uma rápida contração da resina, a 
qual pode afetar negativamente a integridade marginal das restaurações. Assim, os autores consideraram que é necessário o entendimento dos possíveis efeitos da intensidade de luz sobre a geração das tensões de contração e que uma maior qualidade marginal pode ser obtida, através do uso de bases cavitárias que absorvam essas tensões e da utilização da técnica de fotoativação gradual.

Um importante estudo foi realizado por ERNST et al. ${ }^{44}$, em 2000 , no qual examinaram o efeito da fotoativação gradual na redução da tensão gerada durante a polimerização de diferentes materiais restauradores resinosos. Para cada material utilizado, um mínimo de 10 espécimes foram confeccionados e fotoativados a 700 $\mathrm{mW} / \mathrm{cm}^{2}$ por 40 segundos, enquanto que outros 10 espécimes foram fotoativados a $150 \mathrm{~mW} / \mathrm{cm}^{2}$ por 10 segundos, aumentando-se para $700 \mathrm{~mW} / \mathrm{cm}^{2}$ por 30 segundos. Os autores observaram que a utilização da técnica gradual reduziu significativamente o estresse na maioria dos materiais testados, cujo mecanismo parece ser devido a um maior escoamento do material durante a fase pré-gel. Entretanto, este efeito parece ser menos efetivo nas resinas que contêm maior concentração de fotoiniciadores ou em materiais que são mais elásticos, como os compômeros.

Em 2000, BOUSCHLICHER; RUEGGEBERG ${ }^{11}$ avaliaram o desenvolvimento de tensão e o grau de conversão de uma resina composta híbrida, quando submetida a diferentes métodos de fotoativação. Confeccionaram-se espécimes de resina composta (Pertac II), os quais foram polimerizados, utilizando-se quatro diferentes técnicas de fotoativação: convencional a $800 \mathrm{~mW} / \mathrm{cm}^{2}$ por $40 \mathrm{~s}$ (STD), aumento gradual de $150 \mathrm{~mW} / \mathrm{cm}^{2}$ até $800 \mathrm{~mW} / \mathrm{cm}^{2}$ por 15 segundos $+800 \mathrm{~mW} / \mathrm{cm}^{2}$ por 25 segundos (EXP), $150 \mathrm{~mW} / \mathrm{cm}^{2}$ por 10 segundos $+800 \mathrm{~mW} / \mathrm{cm}^{2}$ por 30 segundos (STEP), $400 \mathrm{~mW} / \mathrm{cm}^{2}$ por 80 segundos (MED). As forças provenientes da contração de polimerização foram avaliadas e comparadas entre os grupos e o grau de conversão obtido com as técnicas STD, EXP e MED, verificadas em três profundidades (superficial, a $1 \mathrm{~mm}$ e a $2 \mathrm{~mm}$ ). Os resultados mostraram que as forças máximas de contração foram significativamente menores com a utilização da fotoativação em rampa (EXP). A intensidade intermediária (MED) também resultou em um menor desenvolvimento das forças quando comparada ao STD e ao STEP, porém o MED resultou em um maior grau de conversão que o EXP em uma 
profundidade de $2 \mathrm{~mm}$. A técnica em rampa (EXP) foi capaz de tornar mais lento o grau de conversão do material na superfície e $1 \mathrm{~mm}$ abaixo, contudo apresentou um grau de conversão significantemente equivalente à técnica convencional (STD). Os autores concluíram que a menor velocidade de conversão do material observada com a técnica em rampa colaborou para reduzir a tensão proveniente da polimerização, o que não comprometeria as propriedades físicas desses materiais, uma vez que graus similares de conversão foram obtidos entre esta técnica e a convencional.

Ainda em 2000, SILIKAS; ELIADES; WATTS ${ }^{154}$ investigaram uma possível correlação entre grau de conversão e a resultante das forças de contração de polimerização em duas marcas comerciais de resina composta. Estes autores utilizaram o aparelho Elipar Highlight com as seguintes formas de fotoativação: I$750 \mathrm{~mW} / \mathrm{cm}^{2}$ por 40 segundos; II- $200 \mathrm{~mW} / \mathrm{cm}^{2}$ por 10 segundos seguido de 750 $\mathrm{mW} / \mathrm{cm}^{2}$ por 30 segundos; III- $200 \mathrm{~mW} / \mathrm{cm}^{2}$ por 40 segundos; IV- $200 \mathrm{~mW} / \mathrm{cm}^{2}$ por 10 segundos. O grau de conversão foi avaliado através de espectrofotômetro de raios infravermelhos, sendo que as resinas Z100 e Tetric Ceram foram selecionadas para este estudo. Tanto o grau de conversão como as tensões resultantes da contração de polimerização foram mensuradas continuamente por até 30 minutos após o início da fotoativação. Os autores observaram que o modo II de irradiação não promoveu redução no grau de conversão dos materiais analisados, comparados aos valores obtidos no modo I. Entretanto, os efeitos da redução da intensidade inicial de luz nos modos III e IV promoveram uma redução nas tensões resultantes da contração de polimerização. Para ambos materiais restauradores, houve uma forte correlação entre as forças resultantes da contração de polimerização e os valores de conversão $\left(r^{2}>0,99\right)$. Os autores concluíram que esta correlação significa que uma redução da resultante das forças de contração pode ser conseguida às custas de uma redução aceitável do grau de conversão, mas que deve ser consistente com a obtenção de uma resina com propriedades mecânicas adequadas.

Com o intuito de verificar se a alta irradiação proporcionada pela lâmpada de xenônio prejudica a adaptação marginal de restaurações de resina composta, HASEGAWA et al. ${ }^{69}$, investigaram, em 2001, o efeito das lâmpadas halógena e de 
xenônio quanto à adaptação marginal e à profundidade de polimerização, utilizando quatro diferentes marcas comerciais de resinas compostas. Cavidades cilíndricas foram preparadas na dentina de molares humanos extraídos. Em 120 dentes (grupo 1), aplicou-se o sistema adesivo Mega Bond e, em 180 dentes (grupo 2), foi usado um sistema adesivo experimental, previamente à aplicação das resinas compostas Clearfil APX, Estelite, Silux Plus e Z100. Cada um dos grupos foi subdividido em três grupos com 40 e três com 60 dentes, respectivamente, sendo que cada material foi irradiado com o Apollo 95E por 3 segundos (lâmpada de xenônio), com o Arco Plasma Curing System por 3 segundos (lâmpada de xenônio) e com uma fonte halógena (Witelite por 40 segundos). As fendas foram medidas e a capacidade de polimerização das três fontes de luz foi avaliada através da medição da profundidade de polimerização das resinas compostas. Para medir a profundidade de polimerização, cinco espécimes foram preparados com cada resina composta, os quais foram fotoativados por 10 segundos com a lâmpada de xenônio e por 60 segundos com a halógena. Os resultados mostraram que a profundidade de polimerização obtida com a lâmpada de xenônio foi significativamente maior que a halógena em todas as resinas testadas, enquanto que a adaptação marginal não mostrou deterioração significante. A formação de fendas marginais das resinas Clearfil, Estelite e Silux Plus utilizadas com os dois sistemas adesivos foi prevenida, quando os materiais foram fotoativados tanto com a fonte halógena quanto com a de arco de plasma. Quando do emprego da resina Z100, as fendas avaliadas não foram significativamente diferentes com a utilização das três fontes de luz, porém, quando comparada com as outras resinas compostas, revelou significante aumento das mesmas. Os autores comentaram que a utilização da lâmpada de xenônio para polimerização da resina composta tem a vantagem de reduzir o tempo clínico sem danificar a integridade marginal, se a superfície dentinária for tratada com um adequado sistema adesivo. Concluíram que a utilização da lâmpada de xenônio proporciona maior profundidade de polimerização que a fonte halógena e a adaptação marginal não se apresentou alterada.

Ainda em 2001, KNEZEVIC et al. ${ }^{89}$ avaliaram o grau de conversão (DC) e o aumento da temperatura em quatro resinas comerciais que foram fotoativadas com um aparelho LED e QTH. As resinas compostas utilizadas foram: Tetric Ceram, 
Pertac II, Valux Plus e Degufill Mineral. Os aparelhos fotoativadores utilizados foram: QTH Heliolux GTE (600 mW/cm ${ }^{2}$ ), QTH Elipar Highlight (100 mW/cm², 10 segundos; $700 \mathrm{~mW} / \mathrm{cm}^{2}, 30$ segundos), e um LED com 16 diodos com intensidade mínima de $12 \mathrm{~mW} / \mathrm{cm}^{2}$. Avaliaram-se o DC e o aumento da temperatura na superfície e a $1 \mathrm{~mm}$ de profundidade nos espécimes. Da análise dos resultados, observou-se que a conversão foi somente um pouco maior quando se utilizou o QTH com alta densidade de potência, que promoveu o dobro do aumento da temperatura quando comparado ao LED utilizado. O aumento da temperatura e o grau de conversão foram maiores na superfície do que a $1 \mathrm{~mm}$ de profundidade, independente da fonte de luz utilizada.

Em 2002, AMARAL et al. ${ }^{2}$ avaliaram in vitro a influência das técnicas de fotoativação convencional e soft-start na microinfiltração e microdureza de restaurações classe II de resina composta, inserida de forma incremental ou em um único incremento. Cento e vinte cavidades foram confeccionadas em dentes bovinos, as quais foram restauradas com o sistema adesivo Single Bond e a resina composta Z100. Os dentes foram divididos em 4 grupos, de acordo com a técnica de inserção e de fotoativação da resina, respectivamente: 1- incremento único/ convencional; 2- incremental/ convencional; 3- incremento único/ soft-start; 4incremental/ soft-start. Após a ciclagem térmica $\left(1.000\right.$ ciclos, 5 a $55^{\circ} \mathrm{C}$ por 60 segundos), os espécimes foram imersos em azul de metileno por 4 horas, seccionados e avaliados quanto à microinfiltração. Os resultados mostraram que a técnica de inserção incremental resultou em menor infiltração marginal comparada à inserção em um único incremento, independente da técnica de fotoativação utilizada. A fotoativação pelo método soft-start não foi capaz de reduzir a infiltração, quando comparado ao convencional. Os menores índices de infiltração foram observados quando se associou a técnica incremental e fotoativação convencional. Em termos de microdureza, não houve diferença significante em nenhuma profundidade ao longo dos espécimes entre os grupos avaliados.

BRAGA; FERRACANE ${ }^{14}$, em 2002, com o intuito de promover uma redução nas tensões resultantes da contração de polimerização das resinas compostas, propuseram avaliar os efeitos da adição de um inibidor do processo de polimerização (butilato de hidroxitolueno) para que se reduzisse a velocidade da 
reação. Desta forma, avaliaram o grau de conversão e a geração de tensões provenientes da contração de polimerização de uma resina experimental, com diferentes concentrações do composto inibidor $(0,05 ; 0,2 ; 0,5 ; 1,0 \%)$, que foi fotoativada com uma densidade de potência de $184 \mathrm{~mW} / \mathrm{cm}^{2}$ e variados tempos de exposição (15, 30, 60 e 120 segundos). Da análise dos resultados, observaram-se que tempos mais longos de exposição promoveram um maior grau de conversão, contração de polimerização e tensão. Houve um aumento de 38 \% na conversão (de 39 para 54 \%) quando se compararam os tempos de 15 a 120 segundos. Observouse ainda que houve uma redução de $29 \%$ na resultante das forças de contração quando se adicionou 0,5 e 1,0\%, sendo que quando se compararam 0,05; 0,2 e 0,5 \% não se observou significância. Não houve diferença significante no grau de conversão, mas houve uma tendência de redução na conversão com o aumento da porcentagem do inibidor. De acordo com os autores, as moléculas inibidoras poderiam ligar-se a duas ou mais cadeias poliméricas levando a uma redução na velocidade de reação inicial, até que o inibidor fosse completamente consumido. Desta forma, possibilitaria um aumento da fase pré-gel da resina composta, proporcionando um maior alívio das tensões iniciais de contração. Concluíram que o grau de conversão exerceu uma influência significativa na resultante das forças de contração com uma forte correlação $\left(r^{2}=0,993\right)$, sendo que um aumento da concentração do inibidor promoveu uma redução na taxa de conversão e nas tensões da contração de polimerização, sem que se comprometesse a porcentagem de conversão final.

FAN et al. ${ }^{45}$, ainda em 2002, investigaram a profundidade de polimerização de cinco resinas compostas de diferentes cores quando irradiadas com uma intensidade de $300 \mathrm{~mW} / \mathrm{cm}^{2}$, comparando-se à recomendada pela ISO. A normatização da ISO especifica que as resinas compostas devem apresentar uma profundidade de polimerização mínima de $1,5 \mathrm{~mm}$ quando irradiadas pelo tempo recomendado pelo fabricante e sugerem a utilização de uma intensidade mínima de luz de $300 \mathrm{~mW} / \mathrm{cm}^{2}$, em um espectro de irradiância de 400 a $515 \mathrm{~nm}$. Neste trabalho, as resinas compostas foram fotoativadas pelos tempos recomendados pelos fabricantes. Os autores mediram a profundidade de polimerização através de um método descrito pela ISO e determinaram uma média das cinco amostras 
confeccionadas para cada cor e marca de resina composta utilizada. Os resultados mostraram que treze dos vinte e um materiais testados adequaram-se às especificações feitas pela ISO, enquanto seis dos oito materiais restantes demonstraram a profundidade de polimerização requerida somente quando o tempo de irradiação recomendado pelo fabricante foi dobrado. Os autores concluíram que $300 \mathrm{~mW} / \mathrm{cm}^{2}$ de intensidade de luz parece polimerizar efetivamente a maioria das resinas compostas, quando tempos de exposição apropriados são utilizados. Por outro lado, em alguns casos, houve a necessidade da utilização de maiores tempos do que os recomendados pelo fabricante.

Para avaliar a aplicabilidade do aparelho com arco de plasma, KNEZEVIC et al. ${ }^{90}$, também em 2002, mediram o grau de conversão de três resinas compostas (Tetric Ceram, Pertac II e Z100), quando fotoativadas com PAC Apollo 95E ou com a fonte de luz halógena (Elipar Trilight). O grau de conversão foi avaliado na superfície e a $2 \mathrm{~mm}$ de profundidade. Os espécimes foram fotoativados com o arco de plasma em uma intensidade de $1350 \mathrm{~mW} / \mathrm{cm}^{2}$ por 5 segundos (em passos) e, com a fonte halógena, mediante um aumento gradual da intensidade de luz $\left(200 \mathrm{~mW} / \mathrm{cm}^{2}\right.$ a 700 $\mathrm{mW} / \mathrm{cm}^{2}$ por 40 segundos). Não houve diferença significante nos graus de conversão entre a fotoativação com PAC e com a fonte de luz halógena, tanto na superfície quanto a $2 \mathrm{~mm}$ de profundidade, apesar de mostrarem-se ligeiramente menores quando da utilização do PAC. Um grau mais baixo de conversão foi observado na superfície e a $2 \mathrm{~mm}$ de profundidade na resina composta Z100, quando irradiada com ambas as fontes de luz, notando-se uma diminuição do grau de conversão conforme o aumento da profundidade. Os autores concluíram que o aparelho PAC constitui-se uma alternativa satisfatória, pois, além de utilizar menor tempo clínico, também é capaz de proporcionar um grau de conversão quase equivalente ao obtido com as lâmpadas halógenas.

Para avaliar a efetividade de polimerização obtida com o aparelho de arco de plasma comparado à fonte de luz halógena, a contração de polimerização e a microdureza de duas resinas compostas (Z100 e Tetric Ceram) foram avaliadas por PARK; KREJCI; LUTZ ${ }^{106}$, em 2002. A contração de polimerização foi analisada após a fotoativação com PAC (Apollo 95E) por 2 segundos (grupo 1), 3 segundos (grupo 2), 6 segundos (grupo 3) e 12 segundos (grupo 4); ou com a fonte halógena 
quando utilizados 60 segundos (grupo 5). Quando as resinas compostas foram fotoativadas com PAC por 2 ou 3 segundos, observou-se baixa contração de polimerização comparada à fotoativação por 12 ou por 60 segundos com a fonte halógena. Os autores justificaram que essa baixa contração em 2 ou 3 segundos ocorre devido a uma insuficiente polimerização do material. Adicionalmente, observou-se que a Z100 mostrou contração de polimerização mais rápida que a Tetric Ceram. Para a análise da microdureza de ambas as resinas compostas, espécimes de $2 \mathrm{~mm}$ foram fotoativados por 3, 6 ou 12 segundos com PAC (Apollo 95E) ou com QTH (Optilux 500) por 30 e 60 segundos. Os espécimes de $3 \mathrm{~mm}$ foram fotoativados por 6,12 e 18 segundos com o Apollo 95E ou foram fotoativados convencionalmente com o Optilux 500 por 30 e 60 segundos. Os resultados de microdureza indicaram ausência de diferenças significantes entre os grupos quando avaliada a superfície. Nas regiões mais profundas, a microdureza foi geralmente menor que a obtida na superfície, quando as resinas foram fotoativadas com o Apollo por 3 segundos (recomendado pelo fabricante), não se polimerizando suficientemente. Para os espécimes de $2 \mathrm{~mm}, 12$ segundos de fotoativação com o Apollo foram necessários para a polimerização das regiões mais profundas da resina Tetric, enquanto que para a Z100 as superfícies mais profundas não foram polimerizadas adequadamente, apesar do tempo de exposição ter sido estendido para 12 segundos. Para $3 \mathrm{~mm}$, a região profunda de ambos os materiais não foi polimerizada suficientemente, mesmo quando o tempo foi estendido para 18 segundos. Os autores concluíram que os aparelhos PAC, como o Apollo 95E, não proporcionam uma polimerização adequada das camadas mais profundas da resina composta, quando a espessura se apresenta superior a $2 \mathrm{~mm}$ e requer tempos de exposição maiores que o recomendado pelo fabricante. Para se obter vantagens com este tipo de aparelho, 12 segundos de fotoativação são recomendados para a polimerização do material, desde que este não exceda $2 \mathrm{~mm}$ de espessura.

ASMUSSEN; PEUTZFELDT ${ }^{6}$, em 2003, compararam a propriedade de três marcas comerciais de resinas compostas (Filtek Z250, Pertac II e Definite) que foram fotoativadas com dois aparelhos com diodos emissores de luz azul recentemente lançados no mercado (Elipar FreeLight e e-Light). Os resultados foram comparados quando se utilizou uma fonte de luz com lâmpada halógena para polimerizar as 
mesmas resinas (XL3000). A densidade de potência dos aparelhos foi: XL3000- 400 $\mathrm{mW} / \mathrm{cm}^{2}$; Elipar FreeLight- $300 \mathrm{~mW} / \mathrm{cm}^{2}$; e-Light- $290 \mathrm{~mW} / \mathrm{cm}^{2}$, sendo que todas as resinas foram fotoativadas por 20 segundos. As propriedades analisadas foram resistência flexural, módulo de elasticidade, profundidade e contração de polimerização e ainda a porcentagem de conversão com espectrofotômetro de raios infravermelho. Os autores verificaram que as resinas compostas polimerizadas com os LEDs apresentaram propriedades iguais ou inferiores às propriedades obtidas quando a lâmpada halógena foi utilizada. Apesar disso, a resistência flexural e a profundidade de polimerização preencheram os requisitos necessários determinados pela ISO 4049. Mencionou-se ainda que uma polimerização rápida pode levar ao risco de fendas marginais e que a contração é resultante de um maior grau de conversão e de melhores propriedades mecânicas. O benefício da utilização de um LED com menor densidade de potência, que possibilite uma menor contração, deveria ser levado em consideração.

Em 2003, EMAMI; SÖDERHOLM ${ }^{43}$ avaliaram a hipótese de que o grau de conversão de resinas compostas comerciais está mais relacionado à densidade de energia $\left(\mathrm{mJ} / \mathrm{cm}^{2}\right)$ do que à densidade de potência $\left(\mathrm{mW} / \mathrm{cm}^{2}\right)$. As resinas $Z 100 \mathrm{e}$ Filtek Z250 foram fotoativadas com diferentes densidades de potência e variados tempos de exposição, com uma fonte de luz com lâmpada halógena (Elipar Trilight). Materiais restauradores com várias espessuras $(2,4$ e $6 \mathrm{~mm})$ foram utilizados, sendo que a porcentagem de conversão foi avaliada no topo e na base destas resinas com espectroscopia Raman. Os tempos de exposição foram 5, 10, 20, 40, 60 e 140 segundos. As densidades de potência foram: 200, 450 e $800 \mathrm{~mW} / \mathrm{cm}^{2}$. A porcentagem de conversão total variou de 60 a $65 \%$. Os autores observaram um maior grau de conversão na resina Z250 comparada à Z100 e atribuíram este resultado à presença do monômero UEDMA. As resinas compostas à base de UEDMA são mais reativas que resinas à base de BisGMA. Ainda, na resina Z250 ocorreu a substituição de parte das moléculas de BisGMA por BisEMA $A_{6}$, que se caracteriza por ser uma molécula mais longa e mais flexível. Os autores mencionaram ainda que há uma menor proporção de duplas ligações nas cadeias alifáticas em relação às duplas ligações nos anéis aromáticos. Monômeros menores com um maior número de duplas ligações na cadeia alifática são fatores 
relacionados a uma maior ocorrência de contração de polimerização na Z100. Os autores verificaram ainda que a hipótese de que a conversão de monômeros estaria mais relacionada à densidade de energia do que à densidade potência foi aceita quando se avaliaram as diferentes espessuras de resina.

Já em 2004, NOMOTO; MCCABE; HIRANO ${ }^{101}$ avaliaram o espectro de irradiância, o aumento da temperatura na superfície do dente e a profundidade de polimerização quando se compararam diferentes fontes de luz: PAC - Apollo 95E, Apollo 95E Elite, ARC light IIM, Credi II e Flipo; QTH - New Light-VL II; LED- Elipar Freelight e Luxomax. A densidade de potência e a profundidade de polimerização foram avaliadas de acordo com a ISO 4049. O espectro de irradiância foi avaliado com um espectro-radiômetro e a temperatura na superfície com a utilização de um par termoelétrico (thermocouple). O espectro de irradiância das fontes de luz com arco de plasma foi mais amplo comparado às demais fontes de luz. A densidade de potência dos aparelhos PAC variou de 1.088 a $1.900 \mathrm{~mW} / \mathrm{cm}^{2}$. A densidade de potência da fonte de luz com lâmpada halógena foi $428 \mathrm{~mW} / \mathrm{cm}^{2}$ e dos LEDs foi de $190 \mathrm{~mW} / \mathrm{cm}^{2}$ para o Elipar FreeLight e $98 \mathrm{~mW} / \mathrm{cm}^{2}$ para o Luxomax. Tanto o PAC quanto o LED necessitaram de maiores tempos de exposição comparados aos recomendados pelos fabricantes. Para que se obtivesse uma profundidade de polimerização equivalente a quando se utilizou uma fonte de luz com lâmpada halógena por 20 segundos, necessitou-se a aplicação de um tempo de exposição de seis a nove segundos para os aparelhos PAC e de 40 a 60 segundos para os aparelhos LED. Observou-se ainda que a temperatura na superfície dos dentes irradiados aumentou proporcionalmente com o aumento do tempo de exposição, para todos os aparelhos fotoativadores. A temperatura aumentou de 15 para $60{ }^{\circ} \mathrm{C}$ quando os diferentes aparelhos PAC foram utilizados e ao redor de $15{ }^{\circ} \mathrm{C}$ quando QTH foi utilizado. Em relação aos aparelhos LED, o aumento foi de menos de $10^{\circ} \mathrm{C}$.

BRAGA; FERRACANE ${ }^{13}$, em 2004, publicaram um artigo em que discursaram sobre os diferentes parâmetros associados à contração resultante da polimerização de uma resina composta. Afirmou-se que a resultante das forças de contração está geralmente associada à falhas marginais e internas das restaurações. A magnitude depende de uma série de fatores como a composição da resina (em termos de matriz orgânica e partículas inorgânicas), a habilidade de 
escoamento antes do ponto gel, que por sua vez se relaciona com a configuração da cavidade e com as características de polimerização da resina. Estes autores afirmaram que estudos em que se avaliou a integridade marginal utilizando-se técnicas de polimerização soft-start mostraram resultados contraditórios. Outro aspecto que os autores abordaram foi relacionado aos efeitos da irradiação não contínua na estrutura do polímero. Tem-se especulado que a ocorrência de uma menor taxa de polimerização deve resultar em cadeias poliméricas mais longas, mas com menor número de ligações cruzadas, afetando assim as propriedades mecânicas das resinas compostas. Os autores abordaram também os aspectos relacionados ao conceito da densidade de energia. A utilização de alta densidade de energia tem sido associada a superiores propriedades mecânicas e maior grau de conversão. Entretanto, a correlação entre densidade de energia e grau de conversão não é linear, sendo que há um limite em que alta densidade de energia se traduz em significantes aumentos no grau de conversão e nas propriedades mecânicas. Além disso, infelizmente, há uma relação linear entre a densidade de energia e a contração pós-gel, sendo que altas densidades de energia não se traduzem necessariamente em maior conversão ou propriedades mecânicas superiores. Relatou-se ainda que, clinicamente, seria impossível se determinar qual a densidade de energia que promoveria a melhor relação entre grau de conversão, propriedades mecânicas e tensão de contração.

Poucos trabalhos são encontrados na literatura avaliando a conversão em sistemas adesivos. Em 2004, BANG et al. ${ }^{8}$ avaliaram a correlação da conversão de monômeros com a contração de polimerização, utilizando-se fontes de luz com lâmpada halógena e de arco de plasma para fotoativar um sistema adesivo destinado à Ortodontia. Os autores verificaram que quando polimerizavam o material restaurador com QTH, os valores de conversão total foram superiores comparado aos valores obtidos com o PAC. Além disso, verificaram que houve uma forte correlação entre conversão de monômeros e contração de polimerização quando utilizaram QTH $\left(R^{2}=0,787\right)$. Por outro lado, estes autores encontraram uma fraca correlação quando PAC foi utilizado $\left(\mathrm{R}^{2}=0,377\right)$. Os autores concluíram que houve uma menor contração de polimerização quando se utilizou o PAC para polimerizar o sistema adesivo, devido à altíssima densidade de potência que o aparelho 
apresentava, apesar de que, em termos de ortodontia, isso não representaria um fator tão relevante, uma vez que a espessura do material seria bastante fina. Caso houvesse contração, haveria uma aproximação do bracket ortodôntico em direção à superfície do esmalte.

Os fabricantes têm tentado solucionar os problemas relacionados às limitações dos adesivos dentinários, como a sensibilidade técnica, através da introdução de novos sistemas como os adesivos all-in-one. O efeito da intensidade e fonte de luz sobre o grau de conversão (DC) de adesivos comerciais, contendo diferentes sistemas fotoiniciadores, foi avaliado por YE et al. ${ }^{194}$, em 2005, utilizandose FTIR. Utilizaram-se três adesivos [One-Up Bond F (OBF), Adper Prompt (ADP), Single Bond (SB)], os quais foram fotoativados com dois aparelhos fotoativadores (Spectrum 800 e UltraLume LED5). As intensidades de luz utilizadas com o Spectrum 800 variaram de 300 a $800 \mathrm{~mW} / \mathrm{cm}^{2}$, enquanto que a intensidade do UltraLume LED5 foi fixada em torno de $1.200 \mathrm{~mW} / \mathrm{cm}^{2}$. Durante a irradiação, a polimerização dos adesivos foi monitorada por 60 segundos em intervalos de 3 segundos. O DC foi analisado calculando-se a variação do pico das duplas ligações de carbono $\left(1637 \mathrm{~cm}^{-1}\right)$ em relação ao pico das duplas ligações na cadeia aromática (1714 $\left.\mathrm{cm}^{-1}\right)$, utilizando-se como controle o pico apresentado nos espécimes não polimerizados. Os resultados mostraram que a taxa máxima de conversão do SB e OBF (72 \% e $77 \%$ a 20 e a 25 segundos, respectivamente) é mais rápida que do ADP (59 \% a 40 segundos), quando utilizaram a lâmpada halógena com densidade de potência de $550 \mathrm{~mW} / \mathrm{cm}^{2}$. A intensidade de luz acelerou a polimerização inicial dos espécimes de OBF e SB; houve uma diferença mínima no DC aos 20 segundos com OBF e SB, independente do aparelho e das intensidades de luz utilizadas. $O$ DC dos espécimes de ADP aumentou com o aumento da intensidade de luz, especialmente quando o LED5 foi utilizado. Os autores concluíram que o LED é melhor que a lâmpada halógena em termos de taxa de polimerização e DC para o ADP (que possui o fotoiniciador acrylphophine oxide). Em contraste, a polimerização do SB e OBF ocorre principalmente em função do tempo de exposição, independente da fonte de luz ou intensidades empregadas. Os autores concluíram que a eficiência da fotoativação dos adesivos comerciais pode variar em função da fonte de luz. 


\section{2- Micromorfologia da Interface Adesiva}

O conceito de camada híbrida foi descrito pela primeira vez por NAKABAYASHI; KOJIMA; MASUHARA ${ }^{98}$, em 1982, havendo a otimização da adesão ao tecido dentário através da interpenetração de um adesivo, que continha monômeros hidrofílicos e hidrofóbicos, no interior do substrato dentinário desmineralizado (Figura 1).

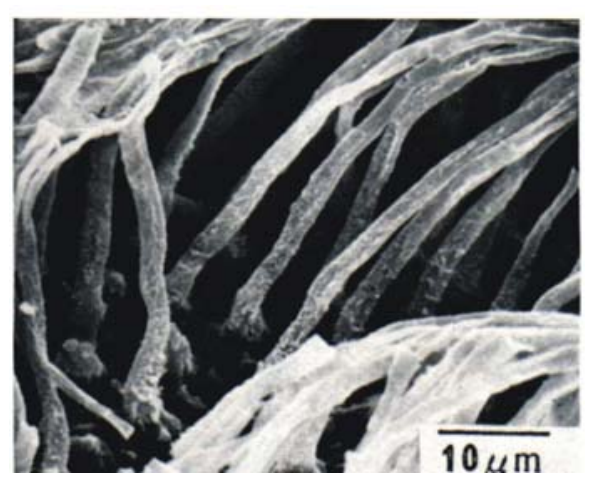

Figura 1 - Interpenetração de adesivo na intimidade dos túbulos; microscopia após a descalcificação da dentina ${ }^{98}$

Amostras de esmalte e dentina humana e bovina foram asperizadas por discos de lixa de papel e submetidas ao condicionamento ácido, através de uma mistura aquosa de ácido cítrico a $1 \%$ e cloreto férrico a 1\%, ou ácido cítrico a $10 \%$ e cloreto férrico a $3 \%$, por 30 segundos. O monômero MMA isoladamente ou o 4-META a 5\% e TBB parcialmente oxidado foram misturados com $0,1 \mathrm{~g}$ de pó de PMMA para preparar o cimento. Pastilhas de acrílico foram então fixadas no esmalte e na dentina com este cimento e, após 24 horas, submetidas ao teste de cisalhamento em uma máquina de ensaios universal. Uma quantidade igual de amostras foi preparada para análise em microscópio eletrônico de varredura. Verificou-se uma resistência ao cisalhamento da ordem de $13,9 \mathrm{MPa}( \pm 4,4)$ para a dentina humana e 15,1 MPa $( \pm 5,3)$ para a dentina bovina, quando empregada a concentração de 10:3 de ácido cítrico e cloreto férrico. $\mathrm{Na}$ análise da microscopia eletrônica, foi observada a presença de tags de resina no interior dos túbulos dentinários, indicando que a adesão ao substrato dentinário foi otimizada por infiltração e penetração dos monômeros, formando-se uma camada ácido-resistente. Este trabalho pioneiro 
contribuiu para o desenvolvimento de novos sistemas adesivos que são utilizados em dentina umedecida e na simplificação do uso dos mesmos.

Somente em 1987 é que WATSON ${ }^{192}$ publicou o primeiro artigo em que estabeleceu as bases da utilização da microscopia de fluorescência para o estudo de estruturas e tecidos dentários. Neste estudo, o autor revisou as vantagens da técnica como sendo relativamente simples e extremamente útil na investigação da interface adesiva tanto in vitro como in vivo. O autor enfatizou ainda que, com esta técnica, há possibilidade da visualização de espécimes sem qualquer preparo especial, obtendo-se imagens com alta resolução, não somente da superfície dos mesmos, mas também em planos abaixo da superfície seccionada. Este recurso possibilita a análise tridimensional da interface adesiva sem o risco de fratura ou de destacamento do material restaurador, freqüente em técnicas de preparação que exigem cortes seriados. A utilização de corantes fluorescentes possibilita a obtenção de informações mais detalhadas da interface dente/restauração. Mencionou-se ainda que estudos devem ser realizados para que haja a possibilidade da incorporação dos corantes à estrutura molecular dos sistemas adesivos, com o intuito de melhorar a confiabilidade da técnica. O autor finaliza o estudo destacando a importância da metodologia de utilização da microscopia de fluorescência como recurso adicional para análise da adaptação de biomateriais à estrutura dentária ou a outros tecidos humanos.

Em 1989, WATSON ${ }^{189}$ utilizou microscopia de fluorescência para a análise da interface adesiva formada quando da aplicação do sistema adesivo Scotchbond 2 em associação com a resina composta P50. O autor adicionou corantes fluorescentes Rodamina B e Fluoresceína aos componentes do sistema adesivo, sendo que filtros apropriados foram utilizados para a observação dos mesmos. Através desta técnica, observou-se uma excelente adaptação do material à dentina, sendo que foram observadas fendas somente quando se aplicou o sistema adesivo de forma incorreta. O autor afirmou ainda que a utilização de microscopia confocal possibilita a análise da sub-superfície de espécimes intactos, sem que haja problemas na obtenção de cortes finos quando se utiliza MET ou na complexidade da obtenção de espécimes para MEV, havendo ainda os problemas relacionados à desidratação dos mesmos. 
Em 1991, WATSON ${ }^{188}$ publicou um artigo no qual descreveu as aplicações da microscopia confocal em odontologia. O autor afirmou que esta técnica de microscopia tornou-se conhecida para diversos campos da ciência, sendo considerada um meio termo entre a microscopia ótica convencional e a microscopia eletrônica. A utilização desta técnica possibilita a obtenção de imagens com alta resolução em espécimes finos de dentes por serem semitransparentes. As imagens da superfície dos espécimes são produzidas de maneira similar às obtidas com MEV, mas com vantagens pela simplicidade da técnica. Além disso, com a possibilidade da obtenção de imagens na sub-superfície, possibilitou-se a obtenção de imagens tridimensionais dos espécimes.

Ainda em 1991, WATSON; BOYDE ${ }^{191}$ descreveram a técnica de análise da interface adesiva utilizando-se de microscopia de fluorescência confocal. Entre outras vantagens, esta técnica possibilita a análise de espécimes finos, sendo que a sub-superfície pode ser também analisada com alta resolução. Adicionalmente, destacaram-se as vantagens da simplicidade da técnica sem que houvesse a remoção dos tecidos calcificados dos dentes. Nesta técnica, os espécimes podem ser mantidos em ambiente úmido, sem que haja as distorções que ocorrem na obtenção de espécimes em MEV. Destacou-se também que pode ser feita a utilização de diferentes corantes fluorescentes nos espécimes, desde que existam filtros para que se evite a ocorrência de resultados falso-positivos. Os corantes podem, ainda, ser adicionados aos diferentes componentes dos sistemas adesivos, demonstrando-se a distribuição dos mesmos na estrutura dentinária. Além disso, estudos avaliando a microinfiltração com microscopia confocal fornecem uma análise mais precisa quando comparada às obtidas com microscopia ótica convencional. Estes autores ainda destacaram outras vantagens e desvantagens, além de cuidados na obtenção e análise dos espécimes.

A morfologia da interface formada pela aplicação do sistema adesivo Syntac sobre a superfície dentinária foi avaliada microscopicamente por WATSON; WILMOT $^{193}$ em 1992. Estes autores realizaram 80 restaurações em terceiros molares recém extraídos. Os preparos foram feitos na forma de cunha na mesial e distal de 40 dentes. Corantes fluorescentes (Rodamina B e Fluoresceína / Auramina) foram misturados aos componentes do sistema adesivo e então aplicados de acordo 
com as instruções dos fabricantes. Em seguida, os dentes receberam o material restaurador (Heliomolar) que foi polimerizado por 40 segundos. Os espécimes foram então seccionados e analisados em microscopia confocal imediatamente e 24 horas após o armazenamento dos espécimes. Os autores avaliaram a presença ou ausência da smear layer, bem como a aplicação de estresse sobre as restaurações obtidas. Verificaram que a espessura da smear layer não prejudicou a penetração dos componentes do sistema adesivo. A interface Syntac/dentina foi capaz de suportar os esforços aplicados, mas mostraram sinais de falhas nos ângulos das cavidades quando as forças de compressão foram grandemente aumentadas. Através da microscopia de fluorescência, os autores puderam detectar que a distribuição do primer foi diferente do adesivo, sendo que o primeiro se distribuiu mais profundamente que o segundo. Por outro lado, o sistema adesivo foi capaz de impregnar em um maior número de túbulos, além de exercer um papel na união com a resina composta. Os autores concluíram enfatizando a necessidade de estudos laboratoriais que possam simular a ocorrência de uma situação clínica, como por exemplo, a utilização de forças de compressão imediatas.

Em 1995, SANO et al. ${ }^{147}$ sugeriram o termo "nanoinfiltração" para descrever a infiltração de íons prata que ocorre na intimidade da interface adesiva em espaços micrométricos e até sub-micrométricos na base da camada híbrida, a qual não foi totalmente preenchida com os monômeros resinosos ou que foram removidos por estarem insuficientes polimerizados. Desta forma, distinguiu-se do termo microinfiltração por ocorrer em espaços de aproximadamente 0,02 $\mu \mathrm{m}$ e por requerer uma técnica de microscopia especial. Nesta técnica os espécimes são mergulhados em uma solução de nitrato de prata, sendo que os íons prata é que migram na intimidade da interface adesiva. Os autores utilizaram neste estudo cinco marcas comerciais de adesivo que foram utilizados para restaurar cavidades classe $V$ na ausência de fendas. Foram observados vários padrões de nanoinfiltração que indicaram a penetração de íons no interior da camada híbrida quando observados em MEV.

Com o intuito de analisar a morfologia da interface adesiva formada com a aplicação de Scotchbond MP, GRIFFITHS; WATSON ${ }^{63}$, em 1995, adicionaram corantes fluorescentes aos diferentes componentes deste sistema adesivo. Para 
isso, os autores selecionaram terceiros molares recém extraídos que receberam preparos cavitários proximais (Figura 2).

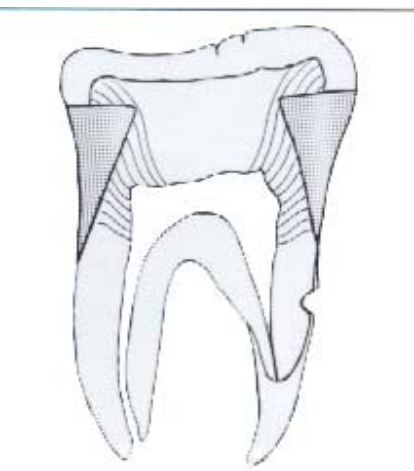
Figura 2 - Preparos cavitários proximais realizados para análise da interface adesiva ${ }^{63}$

O sistema adesivo foi aplicado conforme as instruções do fabricante, sendo que a Rodamina B foi adicionada ao primer e a Fluoresceína ao adesivo. Os autores não especificaram a quantidade de corante fluorescente adicionado, mencionando-se que alguns grânulos foram misturados aos frascos. Utilizou-se de microscopia confocal para análise dos espécimes que foram obtidos após o seccionamento dos mesmos, com um aumento de até 60x. Nas Figuras 3 e 4 observam-se as distribuições do primer e do adesivo quando da utilização do sistema adesivo Scotchbond MP.

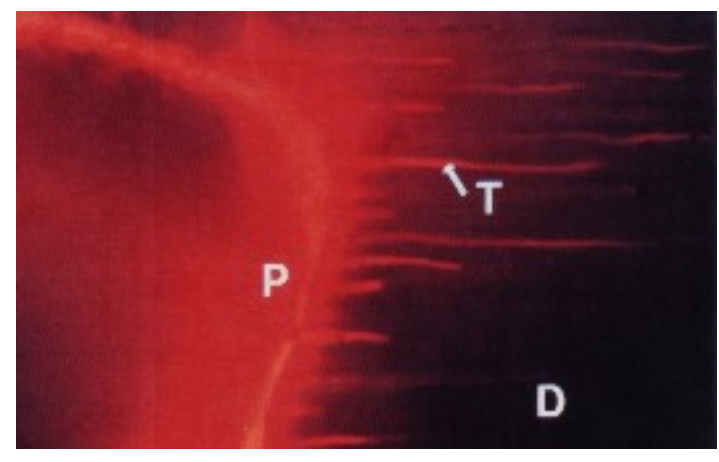

Figura 3- Distribuição dos monômeros do primer $(\mathrm{P})$ do sistema adesivo Scotchbond MP destacado em vermelho $^{63}$ 


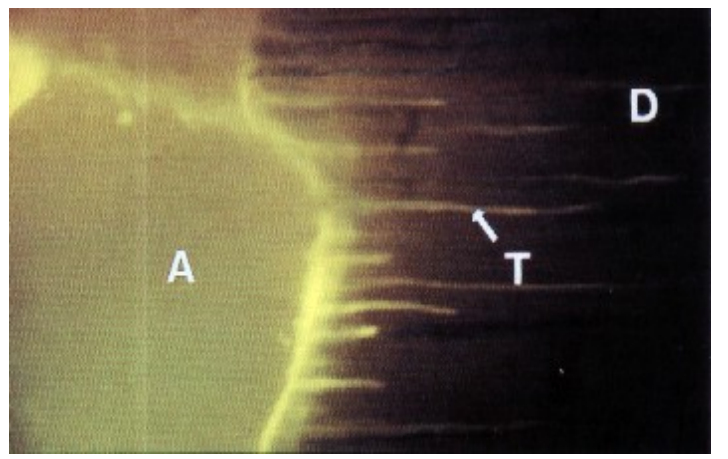

Figura 4- Distribuição dos monômeros do adesivo (A) do Scotchbond MP destacada na cor verde ${ }^{63}$

O primer e o adesivo penetraram nos túbulos dentinários, sendo que uma camada híbrida nítida foi formada com espessura variando de 3 a $4 \mu \mathrm{m}$. Verificou-se que uma fina camada de adesivo estava presente na interface. Entretanto, pode-se verificar que o primer foi algumas vezes removido durante a aplicação do adesivo ou incorporado ao mesmo.

No mesmo ano, TITLEY et al. ${ }^{174}$ propuseram avaliar a composição e a ultraestrutura dos tags de resina formados em dentina condicionada com ácido. Para isso utilizaram dentes humanos e bovinos, sendo que a superfície de dentina foi exposta utilizando-se lixas de granulação 600. Depois disso, aplicaram na dentina várias diluições de soluções aquosas de ácido fosfórico e maleico. O sistema adesivo selecionado foi o Scotchbond MP, sendo que após a sua aplicação foram adicionadas camadas da resina composta Z100. Os dentes foram então submetidos ao teste de resistência adesiva ao cisalhamento e os fragmentos analisados em MEV. Os tags de resina mostraram ser formados por adesivo e por glicosaminoglicanas que preencheram os túbulos dentinários. Baseado nas análises microscópicas, os autores mencionaram que os tags de resina deveriam ser considerados como parte da camada híbrida e não entidades separadas na avaliação da efetividade das uniões adesivas. Os autores concluíram que a eliminação da infiltração marginal está mais baseada na capacidade dos tags de resina em selar efetivamente os túbulos dentinários do que na extensão absoluta dos mesmos.

A determinação da resistência adesiva à dentina e a avaliação da morfologia interfacial pelo MEV de quatro sistemas adesivos de frasco único foram realizadas por PERDIGÃO; RAMOS; LAMBRECHTS ${ }^{115}$, em 1997. Quarenta molares foram desgastados para expor a dentina e aleatoriamente divididos em 4 grupos $(n=10)$ : 
Single Bond (SB), Prime \& Bond 2.1 (PB), Sintac Single-Component (SC), Tenure Quik com flúor (TQ). As superfícies dentinárias foram tratadas de acordo com as instruções dos fabricantes. Após 24 horas em água, os espécimes foram termociclados (500 ciclos, 5 a $55{ }^{\circ} \mathrm{C}, 30$ segundos) e submetidos ao teste de resistência adesiva ao cisalhamento. Adicionalmente, os adesivos foram aplicados em discos de dentina com $600 \mu \mathrm{m}$ de espessura. As interfaces adesivas foram desmineralizadas, desproteinizadas e observadas sob o MEV. Duas características morfológicas foram avaliadas: a profundidade de penetração da resina nos túbulos e a espessura e densidade da zona de interdifusão resina-dentina. Segundo os resultados, o SB mostrou significante maior média de resistência adesiva ao cisalhamento comparado aos demais adesivos. Os espécimes preparados com SC e PB apresentaram valores intermediários, enquanto que os espécimes do TQ exibiram a menor média de resistência adesiva. Todos os materiais penetraram e hibridizaram a dentina. O SB formou uma espessa camada de resina adesiva no topo da área de interdifusão resina-dentina, sem que houvesse rompimento, enquanto que algumas áreas de rompimento adesivo foram observadas no topo das camadas híbridas do PB e SC. O SB apresentou uma área de interdifusão resinadentina de 2,1 a 2,8 $\mu \mathrm{m}$ de espessura, com densa rede de fibrilas de colágeno envolvidas por resina, com completa penetração e hibridização nas ramificações tubulares laterais. Para o adesivo à base de água SC, a zona de interdifusão exibiu um padrão espesso, contendo espaços abertos esparsos entre as fibrilas de colágeno envolvidas por resina. O TQ não infiltrou completamente a zona dentinária desmineralizada, resultando em fendas largas em todos os espécimes. O PB formou os tags de resina mais curtos, enquanto que o SC formou os tags mais longos. Os autores comentaram que variações na espessura da camada híbrida têm pouca influência na resistência adesiva. Talvez, outros fatores apresentem papel mais importante na obtenção de fortes adesões, tais como o grau de impregnação do monômero, a área de dentina intertubular, o diâmetro e número dos túbulos, 0 número e extensão dos túbulos secundários e a área de contato com a dentina normal na base da camada desmineralizada. Concluiu-se que a adesão à dentina permanece incerta utilizando-se sistemas adesivos de frasco único. A química de cada material deve ser mais importante que o tipo de solvente. 
No mesmo ano, WATSON ${ }^{190}$ publicou uma revisão de literatura em que destacou cuidados a serem tomados quando da utilização da microscopia confocal. Este autor mencionou que, idealmente, os corantes fluorescentes deveriam estar bem fixados aos tecidos que estão sendo examinados, pois senão as imagens seriam representativas da distribuição do corante fluorescente e não do material ao qual ele está unido. Destacou-se ainda a possibilidade de haver uma sobreposição das curvas de emissão quando da utilização de mais de um corante, sendo que cuidados devem ser tomados para evitar a ocorrência de resultados falso-positivos. Foram ainda mencionadas algumas vantagens da técnica em que imagens com alta resolução poderiam ser obtidas tanto da superfície como abaixo dela. Para que se obtivesse imagens com maior resolução, sugeriu-se a utilização de uma lente objetiva de imersão com alta abertura numérica (NA). Nesta revisão, o autor já destacava a importância da microscopia de fluorescência como sendo uma excelente técnica de investigação e a evolução do confocal como o Laser de Fóton Duplo.

PIOCH et al. ${ }^{128}$, ainda em 1997, publicaram uma revisão de literatura na qual descreveram as aplicações da técnica de microscopia de fluorescência confocal para avaliação da interface adesiva de restaurações de resina composta. Os autores afirmaram que esta técnica de microscopia possibilitou uma nova forma de avaliação da morfologia da interface. Foi mencionado um estudo no qual os autores compararam o resultado da análise da interface adesiva com MEV e confocal, utilizando-se sete sistemas adesivos comerciais. A microscopia de fluorescência forneceu imagens mais detalhadas da interface devido à técnica não destrutiva e à possibilidade de distinção entre os componentes dos sistemas adesivos. Nas Figuras 5 e 6 observam-se fotomicrografias da interface adesiva analisadas em microscopia confocal. Para a maioria dos sistemas adesivos, a mensuração da espessura da camada híbrida foi possível mesmo quando o corante fluorescente foi somente aplicado ao primer. Quando a Rodamina B foi aplicada em testes de permeabilidade da interface adesiva, os resultados foram correspondentes aos obtidos por SANO et al. ${ }^{147}$, em 1995, que denominaram "nanoinfiltração". Concluíram que a técnica de microscopia confocal pode oferecer uma maior riqueza 
de detalhes a respeito da morfologia e, assim, pode ser utilizada em associação a outros métodos convencionais para que se obtenha o máximo de informação.
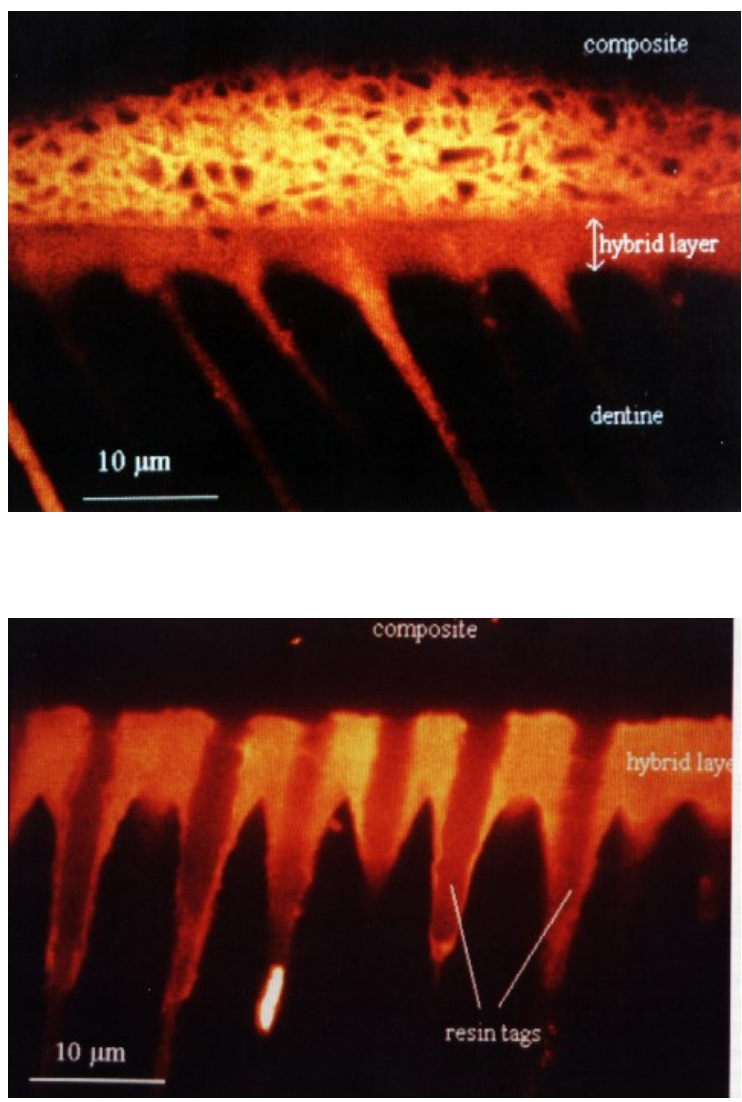

Figura 5-Fotomicrografia mostrando a interface adesiva formada com Syntac, destacada pela adição de Rodamina $B^{128}$

Figura 6-Fotomicrografia mostrando a interface adesiva formada com Gluma CPS, destacada pela adição de Rodamina $\mathrm{B}^{128}$

Os primeiros autores a mencionarem o termo "teste de micropermeabilidade" foram SIDHU; WATSON ${ }^{153}$, em 1998. Este teste compreende a permeabilidade da interface dente/restauração a um corante fluorescente, quando analisado microscopicamente. Neste caso, ocorre o movimento de uma solução contendo corante no sentido dentina/restauração através da interface. Na eventual presença de fendas na interface, haveria o acúmulo de corante, permitindo a análise de possíveis rotas de infiltração na interface. Neste estudo, os autores realizaram preparos cavitários cervicais em dentes extraídos que foram restaurados com diferentes marcas comerciais e tipos de cimento de ionômero de vidro. Aplicou-se o corante fluorescente Rodamina B por 3 horas, em uma concentração de 2,09 x $10^{-5}$ 
$\mathrm{mol} / \mathrm{ml}$ em água deionizada, na câmara pulpar dos dentes restaurados. Os espécimes foram seccionados e analisados em microscopia de fluorescência confocal com aumento de até 60x, utilizando-se lentes de imersão em óleo (NA = $1,4)$. Os autores verificaram que a absorção de corante fluorescente pelos materiais restauradores variou de acordo com o cimento ionomérico utilizado. Atribuiu-se esta área de absorção ao fluxo de água presente na matriz dos cimentos durante o processo de maturação, que variou de acordo com variações na umidade das cavidades e com a comunicação com a polpa dentária nos dentes umidecidos.

No mesmo ano, PIOCH et al. ${ }^{127}$ tentaram correlacionar a espessura da camada híbrida formada e a influência de diferentes tempos de condicionamento ácido na resistência adesiva de restaurações de resina composta. Utilizaram-se cinco marcas comerciais de sistema adesivo (Gluma CPS, Syntac, Scotchbond MP, Single Bond, Prime \& Bond), que foram aplicados na dentina de acordo com as instruções dos fabricantes. Para análise da microscopia confocal, variaram-se os tempos de aplicação do ácido (sem aplicação, 15, 30, 60 e 120 segundos). O corante Rodamina B (isothiocyanate) foi adicionado aos sistemas adesivos. Após a aplicação do sistema adesivo, aplicou-se uma camada de resina composta. Em seguida, os dentes foram seccionados para serem analisados em microscopia confocal. A espessura da camada híbrida foi mensurada medindo-se a distância entre a união dentina/resina composta e o limite da superfície condicionada. Para o teste de resistência adesiva, os dentes foram restaurados da mesma forma, variando-se o tempo de condicionamento (sem ácido, 15, 30, 60, 120 e 180 segundos). A análise dos resultados de microscopia revelou que a camada híbrida foi observada em todos os espécimes que receberam condicionamento ácido. A espessura da camada híbrida formada quando se utilizou o Single Bond variou de $1,79 \mu \mathrm{m}( \pm 0,60)$ para 15 segundos de condicionamento ácido até $5,94 \mu \mathrm{m}( \pm 2,27)$ para 120 segundos de condicionamento. Verificou-se ainda uma correlação exponencial entre os tempos de condicionamento e a espessura da camada híbrida. O teste de resistência adesiva revelou também maiores valores de união quando se utilizou o tempo de condicionamento de 15 segundos, seguido de 30 e 60 segundos. Os valores de resistência adesiva foram significantemente maiores que os observados quando não se aplicou ácido ou quando o tempo de aplicação foi de 120 
e 180 segundos. Os autores não encontraram uma correlação linear entre a espessura da camada híbrida e a resistência adesiva. Na Figura 7, a seguir, observa-se a interface adesiva formada com a aplicação do sistema adesivo Scotchbond MP quando se aplicou o ácido fosfórico por 120 segundos.

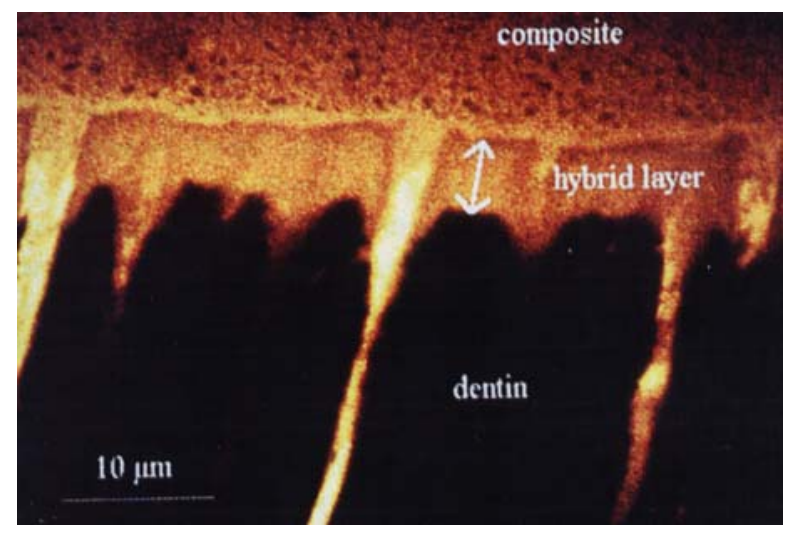

Figura 7-Fotomicrografia mostrando a interface adesiva do adesivo Scotchbond MP, destacada pela adição de Rodamina $\mathrm{B}^{127}$

Em 1999, GRIFFITHS; WATSON; SHERRIFF ${ }^{64}$ avaliaram a influência das propriedades e da aplicação de primers e adesivos na morfologia e micropermeabilidade da camada adesiva, utilizando-se uma técnica de microscopia confocal. Para isso, os autores utilizaram sistemas adesivos experimentais e comerciais que foram aplicados em preparos cavitários proximais. Corantes fluorescentes (Rodamina B e Lucifer Yellow) foram adicionados aos componentes dos adesivos (Optibond, Clearfil Liner Bond 2 e Pertac Universal Bond) para análise da interface adesiva, ou aplicados na câmara pulpar por 3 horas (Rodamina B; 0,5 g em $50 \mathrm{ml}$ ) para que se avaliasse a micropermeabilidade. Os dentes foram seccionados e avaliados em microscopia confocal com um aumento de até 100x com lentes de imersão em óleo $(N A=1,4)$. A Figura 8 corresponde à representação esquemática da avaliação da micropermeabilidade da interface. Os resultados mostraram que todos os primers e adesivos apresentaram uma boa penetração na dentina, com exceção do Pertac Universal Bond, o qual manifestou $100 \%$ de micropermeabilidade por não promover a remoção da smear layer (controle). Os menores valores de micropermeabilidade foram obtidos pelo Clearfil Liner Bond 2, Optibond e por um adesivo experimental de 2 passos. Quando monômeros 
polimerizáveis por luz foram adicionados aos primers, maiores valores de micropermeabilidade foram observados. A associação primer e adesivo foi importante para a minimização da micropermeabilidade, sendo que primers contendo monômeros não fotoativáveis foram melhores no sentido de absorver a resultante das forças de contração devido a uma elasticidade intrínseca, quando comparados ao adesivo com primers fotoativados. Os autores concluíram que a técnica de microscopia confocal foi capaz de fornecer o exame preciso do grau e do local da micropermeabilidade nas interfaces analisadas.

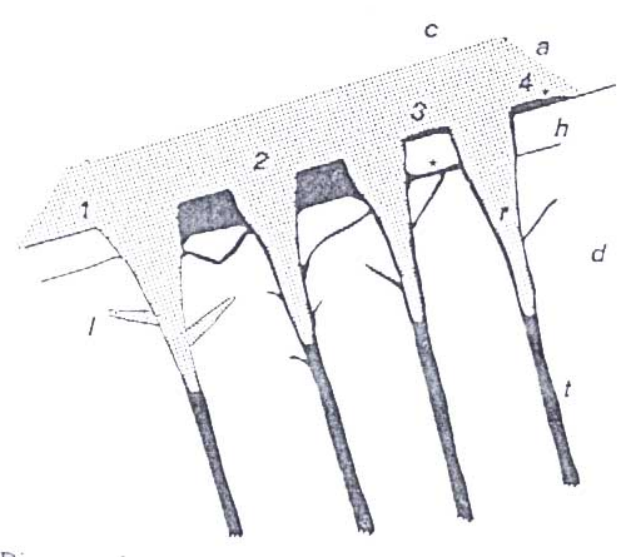
Figura $\begin{aligned} & 8-\text { Diagrama do teste de } \\ & \text { micropermeabilidade: }\end{aligned}$

1- sem micropermeabilidade;

2- micropermeabilidade ao redor dos tags de resina;

3- micropermeabilidade na base da camada híbrida;

4- micropermeabilidade na camada híbrida propriamente dita ${ }^{64}$

PIOCH et al. ${ }^{123}$, em 1999, avaliaram se o tratamento da dentina desmineralizada com hipoclorito de sódio não causaria uma redução na resistência adesiva, mas eliminaria a camada híbrida. Para isso, os autores utilizaram 120 dentes que foram restaurados com resina composta, aplicando-se diferentes sistemas adesivos. A interface formada entre o material restaurador e a dentina foi analisada em MEV e em microscopia confocal. Os dentes foram também utilizados para o teste de resistência adesiva. Setenta e cinco dentes foram tratados com hipoclorito a $10 \%$ após o condicionamento ácido. Os demais foram normalmente 
restaurados e funcionaram como controle. Nas Figuras 9 e 10 observam-se exemplos de imagens obtidas com MEV e com microscopia de fluorescência.
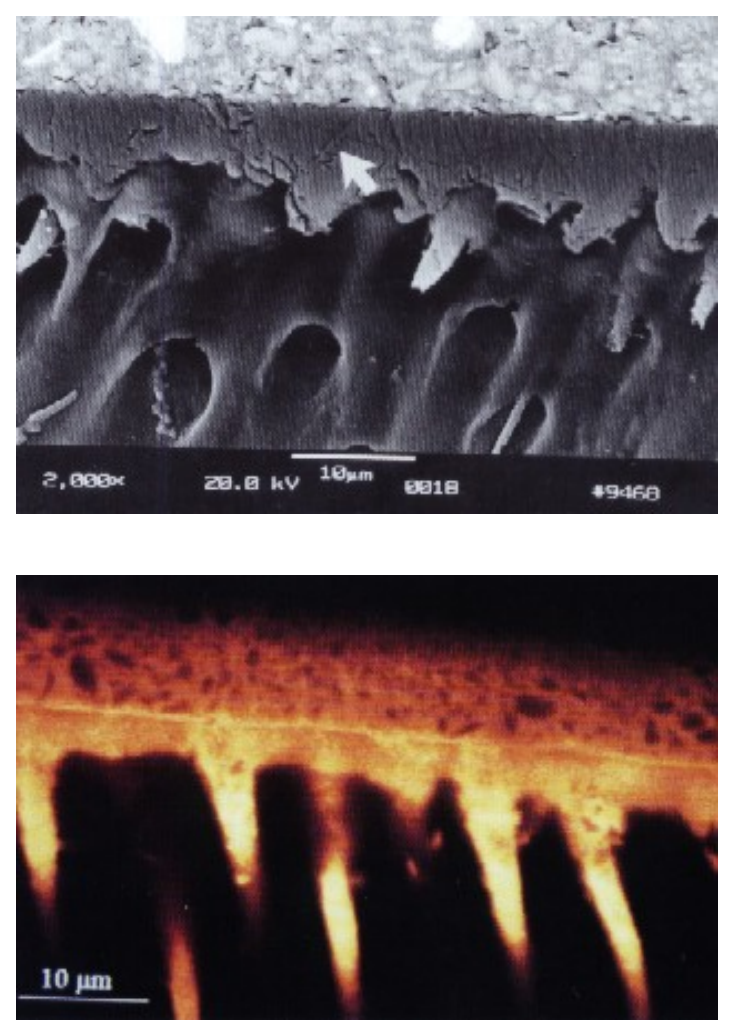

Figura 9 - Fotomicrografia em MEV mostrando a interface adesiva do sistema adesivo Syntac; destaca-se (seta branca) a camada híbrida ${ }^{123}$

Figura 10 - Fotomicrografia em confocal; interface adesiva do Gluma CPS $^{123}$

Os resultados mostraram que os dentes que receberam aplicação de hipoclorito de sódio a camada híbrida não foi visível, mas havia presença de tags de resina nos túbulos dentinários e ramificações laterais. O tratamento com hipoclorito também resultou na redução da resistência adesiva de certos adesivos (Syntac e Gluma CPS), mas em outros promoveu um aumento (Prime \& Bond 2.1). Os autores concluíram que a remoção das fibrilas de colágeno pela aplicação do hipoclorito de sódio pode resultar no aumento ou diminuição dos valores de resistência adesiva, dependendo do sistema adesivo utilizado.

GRIFFITHS et al. ${ }^{62}$, em 1999, afirmaram que os sistemas adesivos são submetidos à resultante das forças de contração de polimerização durante a polimerização da resina composta. Desta forma, os autores propuseram-se a analisar a morfologia e micropermeabilidade da interface adesiva em dentes que receberam diferentes restaurações adesivas com diferentes materiais restauradores. 
Para análise da morfologia desta área, adicionaram-se corantes fluorescentes aos diferentes componentes do sistema adesivo utilizado (Scotchbond MP Plus). Foram realizadas restaurações adesivas a amálgama (Dispersalloy), de resina composta (Z100) fotoativada em alta e baixa intensidade, e ainda restaurações com resina composta quimicamente ativada (Adaptic). Os materiais restauradores foram aplicados em preparos cavitários com 2 e $4 \mathrm{~mm}$ de profundidade, realizados em 55 terceiros molares humanos. Para a análise da micropermeabilidade, 15 dentes receberam preparos cavitários tipo caixa ou tiveram a superfície planificada para a avaliação de diferentes fatores de configuração cavitária. Neste caso, uma solução salina contendo um corante fluorescente (Rodamina B; 0,5 gr em $50 \mathrm{ml}$ ) foi aplicada à câmara pulpar dos mesmos durante 4 horas. Nas Figuras 11 e 12 observam-se os fatores cavitários avaliados neste estudo. Ambas avaliações foram realizadas em microscopia confocal.

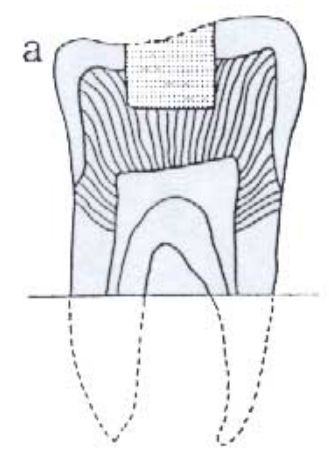

Figura 11 - Preparo cavitário classe I realizado para análise da interface adesiva ${ }^{62}$

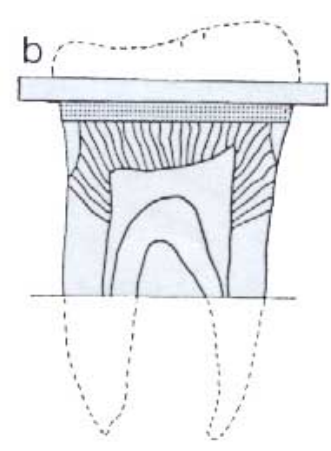

Figura 12 - Superfícies planas de dentina foram restauradas para análise comparativa da interface adesiva ${ }^{62}$ 
A análise da morfologia da interface dente-restauração mostrou que houve uma boa penetração do primer e adesivo na dentina desmineralizada. Observou-se que o primer penetrou cerca de $10 \mu \mathrm{m}$ de profundidade, sendo que a sua presença foi observada como uma área distinta. Verificou-se que as restaurações com Z100 nos preparos tipo caixa apresentaram maior micropermeabilidade comparadas às restaurações a amálgama e Adaptic. Não se observou diferença significante nos resultados de micropermeabilidade quando se compararam alta e baixa intensidade de luz, mas foram observadas evidências de polimerização incompleta na base da restauração quando se utilizou baixa densidade de potência. Quando a alta densidade foi utilizada, verificaram-se ocorrências de falhas coesivas e formações de fendas. Os menores valores de micropermeabilidade com restaurações de Z100 foram observadas quando o material foi aplicado à superfície plana em dentina. Os autores concluíram que a integridade da interface adesiva em cavidades tipo caixa foi dependente da resultante das forças de contração sobre a mesma. Restaurações de resina composta se comportaram melhor quando aplicadas em cavidades rasas e fotoativadas com baixa intensidade de luz.

D'SOUZA et al. ${ }^{42}$, em 1999, utilizaram microscopia confocal para avaliar comparativamente a interface de restaurações adesivas com a microscopia de varredura. Estes autores testaram a hipótese nula de que haveria uma correlação entre as duas técnicas. Selecionaram-se seis sistemas adesivos que foram aplicados à superfície dentinária plana de terceiros molares humanos recém extraídos. Após aplicação dos sistemas adesivos, de acordo com as normas dos respectivos fabricantes, aplicou-se uma camada de resina composta. Para a técnica de microscopia de varredura, desidrataram-se os espécimes em concentrações seqüenciais de etanol por 24 horas. Os espécimes foram então secados utilizandose o método de ponto-crítico e metalizados para análise em microscópio de varredura. Para a técnica de microscopia confocal, adicionou-se o corante fluorescente Rodamina $\mathrm{B}$, que era insolúvel em água (isothiocyanate), numa concentração de 0,1\%. Os espécimes foram analisados a uma magnitude de 100 vezes, selecionando-se $10 \mu \mathrm{m}$ abaixo da superfície. Nas Figuras 13 e 14 podem ser observadas as diferenças de técnica. Os autores verificaram que enquanto a microscopia de varredura forneceu dados, muitas vezes, relacionados a artefatos, a 
microscopia confocal possibilitou novas informações sobre a morfologia da interface, superando algumas das dificuldades e desvantagens associadas a outras técnicas de microscopia. A utilização de corantes fluorescentes forneceu informações importantes, sendo que os autores sugerem a utilização desta técnica em complementação a outras técnicas de microscopia.
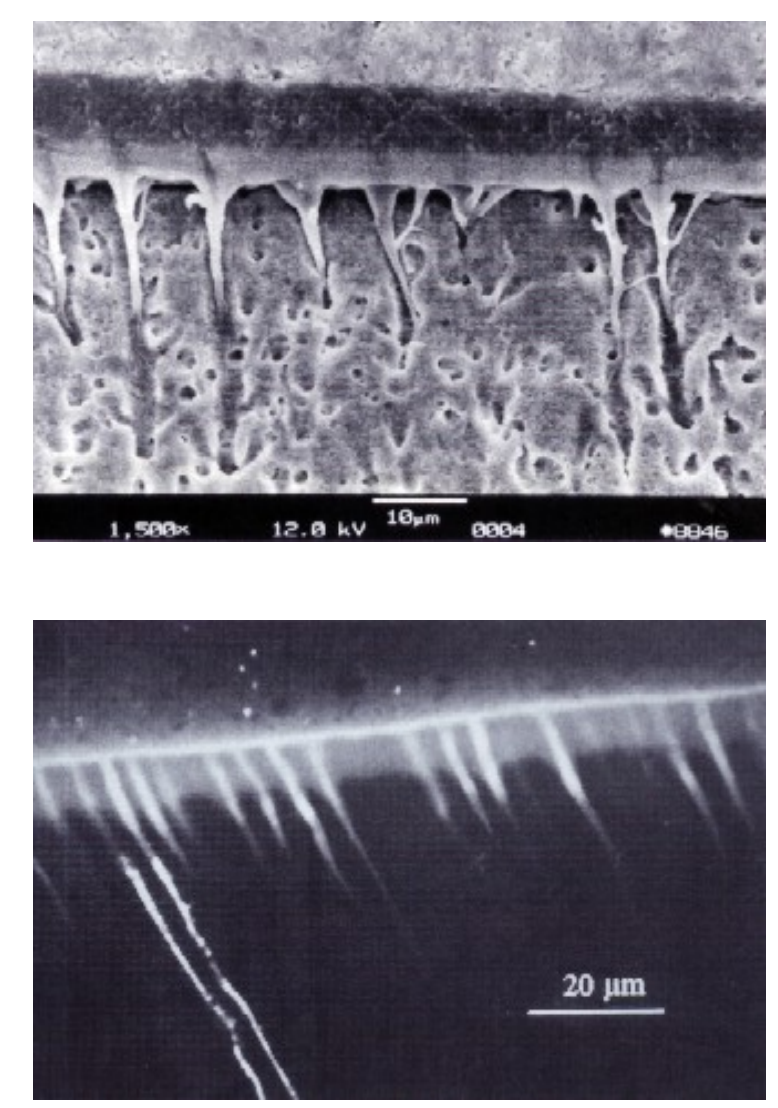

Figura 13 - Fotomicrografia da interface formada pelo sistema adesivo Syntac, observada em MEV ${ }^{42}$

Figura 14 - Fotomicrografia da interface formada pelo sistema adesivo Optibond, observada em confocal $^{42}$

Em 2000, estudando a nanoinfiltração com microscopia confocal, DÖRFER et al. ${ }^{41}$ avaliaram a influência de diferentes sistemas adesivos, da termociclagem e do tempo de condicionamento ácido na integridade da interface adesiva. Os autores propuseram quantificar a nanoinfiltração em espécimes tratados com seis sistemas adesivos. Para um deles, diferentes tempos de condicionamento ácido foram utilizados (Syntac classic) e para dois deles realizou-se termociclagem (Gluma CPS e Syntac classic). Os sistemas adesivos foram aplicados a preparos padronizados de classe $\mathrm{V}(3,0 \times 3,0 \times 2,0 \mathrm{~mm}$ profundidade $)$ com margens cervicais em dentina, os 
quais foram preparados em 165 molares humanos recém extraídos. Os sistemas adesivos avaliados foram: Gluma CPS, Gluma One Bond, Syntac classic, Single Bond, Optibond e Prime\& Bond NT. Depois da aplicação do adesivo e da finalização da restauração com resina composta, os dentes foram imersos em uma solução alcoólica de Rodamina B (isothiocyanate) a $1 \%$ por 24 horas a $20{ }^{\circ} \mathrm{C}$. Os dentes foram incluídos e seccionados paralelamente ao longo eixo dos dentes. Os espécimes foram analisados em microscopia confocal, sendo que se padronizou 10 $\mu \mathrm{m}$ abaixo da superfície. Mediu-se a penetração do corante na interface adesiva, que representou então a quantidade de nanoinfiltração. A Figura 15, a seguir, representa uma fotomicrografia da interface analisada em microscópio confocal.

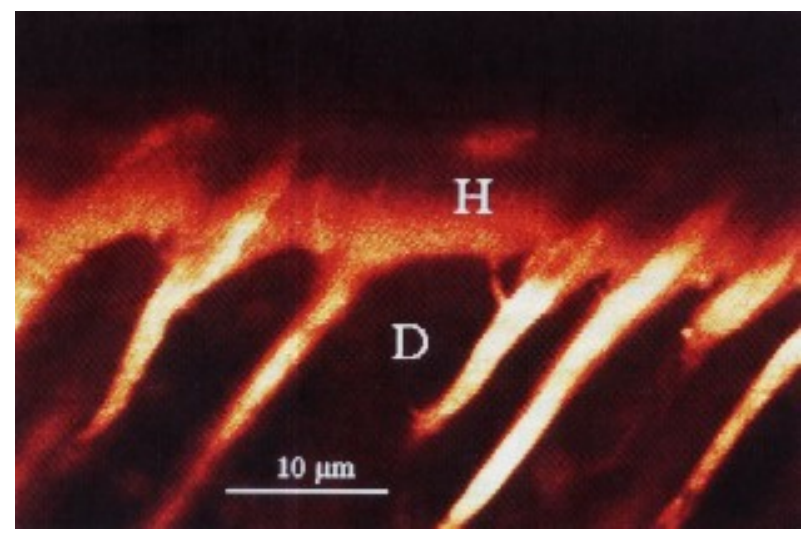

Figura 15 - Fotomicrografia da interface formada quando o Optibond foi aplicado; observada em microscopia confocal $^{41}$

Em todos os materiais testados ocorreu a presença de caminhos de infiltração no interior da camada híbrida, apesar da ausência de fendas. A extensão da infiltração nos materiais avaliados variou de $69 \mu \mathrm{m} \pm 24$ até $469 \mu \mathrm{m} \pm 333$. A termociclagem não produziu efeito significante, mas o tempo de condicionamento de 15 segundos resultou em penetração significantemente menor de corante na interface em comparação a tempos mais longos de condicionamento.

CHOI; CONDON; FERRACANE ${ }^{24}$, em 2000, objetivaram avaliar as alterações na resultante das forças de contração em restaurações adesivas, variando-se a espessura da camada de adesivo, e uma possível correlação entre esses parâmetros, nas margens cavitárias de cavidades classe V. Para isso, avaliou-se a máxima força de contração de uma resina composta (Herculite XRV) em um 
tensilômetro, de acordo com variações na espessura da camada de adesivo (Scotchbond MP) de 20 a $300 \mu \mathrm{m}$. A resina foi aplicada nas cavidades de classe $\mathrm{V}$ preparadas na superfície vestibular de dentes bovinos, as quais também receberam diferentes espessuras de adesivo e foram avaliadas através do teste de microinfiltração com nitrato de prata. Os autores verificaram que a resultante das forças de contração de polimerização diminuiu com o aumento da espessura de adesivo. Ocorreu diminuição significante nas forças de contração quando a espessura da camada de adesivo ultrapassou $100 \mu \mathrm{m}$. Em relação aos resultados do teste de microinfiltração, observou-se que a aplicação de camadas adicionais de adesivo na área marginal promoveu uma redução geral no grau de penetração do corante utilizado. As forças de contração geradas durante a aplicação da resina composta contribuíram significantemente para a infiltração marginal precoce, sendo que as mesmas foram absorvidas e aliviadas pela aplicação de espessuras incrementais de adesivos. Os autores concluíram que o aumento da espessura da camada de adesivo, através da aplicação de camadas adicionais do mesmo, deve levar a uma melhor integridade marginal e, como conseqüência, a uma maior longevidade das restaurações adesivas.

Ainda em 2000, DIASPRO; ROBELLO ${ }^{40}$ publicaram uma revisão de literatura na qual descreveram a utilização da técnica de microscopia de fluorescência com Laser de Fóton Duplo (TPE) para análise tridimensional de estruturas biológicas. Destacou-se que esta técnica é, comparativamente, uma nova forma de microscopia que utiliza um laser que opera no comprimento de onda de 640 a $1.000 \mathrm{~nm}$, em uma altíssima freqüência $(100 \mathrm{MHz})$ e com pulsos de 100 fentosegundos $\left(100 \times 10^{-15}\right.$ segundos). Os autores afirmaram ainda que a microscopia confocal convencional apresenta uma importante desvantagem em relação ao photobleaching, processo pelo qual há destruição dos corantes fluorescentes, e em relação à fototoxicidade do laser que atinge os espécimes durante a análise microscópica. Esta situação é dramaticamente atenuada no caso do TPE, que permite um mínimo volume de excitação com comprimento de onda de menor energia (far red-field). Devido ao processo físico que ocorre, os corantes fluorescentes são excitados simultaneamente por dois fótons, sendo que agindo de forma sinérgica (para o mesmo corante, ao mesmo tempo) fornecem energia suficiente para que a 
fluorescência ocorra. Na Figura 16 está representado esquematicamente o processo de excitação, utilizando-se o confocal convencional $\left(\lambda_{1}\right)$ e o Laser de Fóton Duplo $\left(\lambda_{A}\right.$ $\left.e_{B}\right)$.

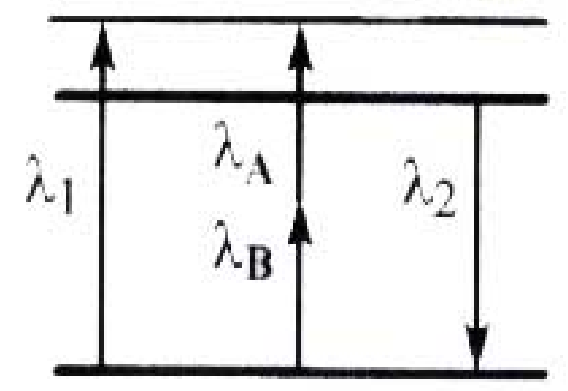

Figura 16 - Representação esquemática do processo de excitação de um corante fluorescente com Confocal convencional $\left(\lambda_{1}\right)$ e com Laser de Fóton Duplo $\left(\lambda_{\mathrm{A}} \mathrm{e}_{\mathrm{B}}\right)^{40}$

Em 2001, PIOCH et al. ${ }^{124}$ publicaram uma revisão de literatura a respeito da nanoinfiltração na interface dente/restauração. Estes autores mencionaram que o termo nanoinfiltração foi introduzido para descrever um tipo específico de infiltração no interior das margens das restaurações. Afirmaram ainda que a nanoinfiltração ocorre em conseqüência do condicionamento ácido, que favorece a penetração de fluidos pulpares ou orais no interior das porosidades adjacentes ou no interior da camada híbrida, sendo independente da microinfiltração. A quantidade de penetração depende do tipo de sistema adesivo utilizado e também dos diferentes parâmetros da técnica de aplicação (ex.: tempo de condicionamento, umidade da dentina, etc.). Mencionou-se ainda que a nanoinfiltração é menos extensa que a microinfiltração e que, provavelmente, não tem significância clínica a curto prazo. A estabilidade a longo prazo, entretanto, parece ser negativamente afetada. Apesar disso, os autores recomendam que a aplicação de ácido, antes do sistema adesivo, ainda deva ser realizada.

Em 2002, BESTVATER et al. ${ }^{9}$, estudando corantes fluorescentes, avaliaram se havia alteração nas curvas de emissão quando se utilizava o Laser de Fóton Duplo, já que os mesmos são excitados por um comprimento de onda além da região de luz vermelha do espectro de luz visível (far red-field). Sendo assim, uma 
série de corantes fluorescentes foram selecionados, dentre os quais Rodamina B e Fluoresceína. Os autores verificaram que a maioria dos corantes não revelou discrepâncias significantes nas curvas de emissão quando se comparou com as curvas obtidas com o confocal convencional. Nas Figuras 17 e 18 observam-se as curvas de excitação e emissão dos corantes Rodamina B e Fluoresceína, quando excitados com Laser de Dois Fótons em dois comprimentos de onda diferentes.

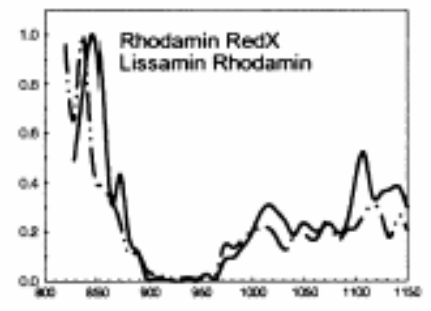

(A) Absorção (nm)

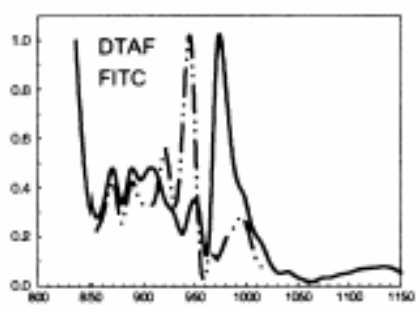

(A) Absorção (nm)

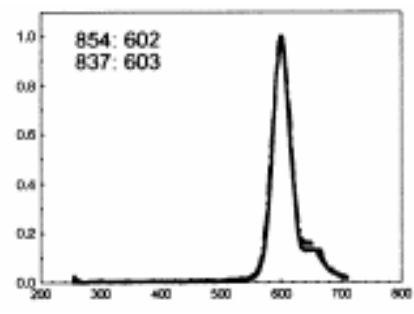

(B) Emissão (nm)

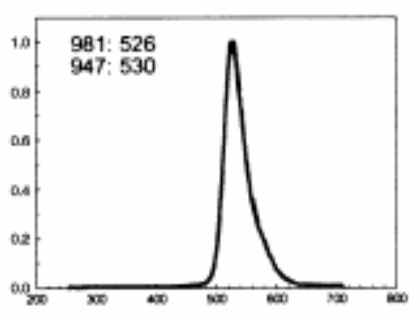

(B) Emissão (nm)
Figura 17 - Curvas de absorção (A) e emissão (B) da Rodamina B em Laser de Fóton Duplo ${ }^{9}$

Figura 18 - Curvas de absorção (A) e emissão (B) da Fluoresceína em Laser de Fóton Duplo ${ }^{9}$

Observou-se que não houve alteração no pico de emissão com o Laser de Fóton Duplo, já que as curvas são bastante similares às obtidas com o microscópio confocal convencional.

Objetivando avaliar o grau de nanoinfiltração em cavidades classe V, PIOCH et al. ${ }^{126}$, em 2002 , utilizaram três sistemas adesivos comerciais que foram aplicados à dentina úmida e seca. Para isso, os autores selecionaram 66 molares recém extraídos que receberam preparos cavitários medindo $3,0 \times 3,0 \times 2,0 \mathrm{~mm}$ de profundidade. Os sistemas adesivos utilizados foram Single Bond, Gluma CPS e Prime \& Bond NT. Os preparos foram restaurados com resina composta e os dentes foram então submersos em uma solução alcoólica a $50 \%$, contendo $1 \%$ em peso de Rodamina B (isothiocyanate), por 24 horas a $20{ }^{\circ} \mathrm{C}$. Os dentes foram lavados, 
incluídos e seccionados paralelamente ao longo eixo do dente, separando-os em duas metades. Os espécimes foram analisados em microscopia confocal, sendo que se padronizou uma profundidade de $10 \mu \mathrm{m}$. A extensão de penetração do corante na interface adesiva foi avaliada, representando a quantidade de nanoinfiltração. Os resultados mostraram que houve diferença estatisticamente significante entre os materiais avaliados. O ressecamento da dentina produziu efeitos negativos tanto no adesivo à base de acetona (Prime \& Bond NT) como no adesivo à base de álcool (Single Bond), porém não para o à base de água (Gluma CPS). Na Figura 19 observa-se a fotomicrografia da interface formada com a utilização do Prime \& Bond NT realizado em dentina úmida.

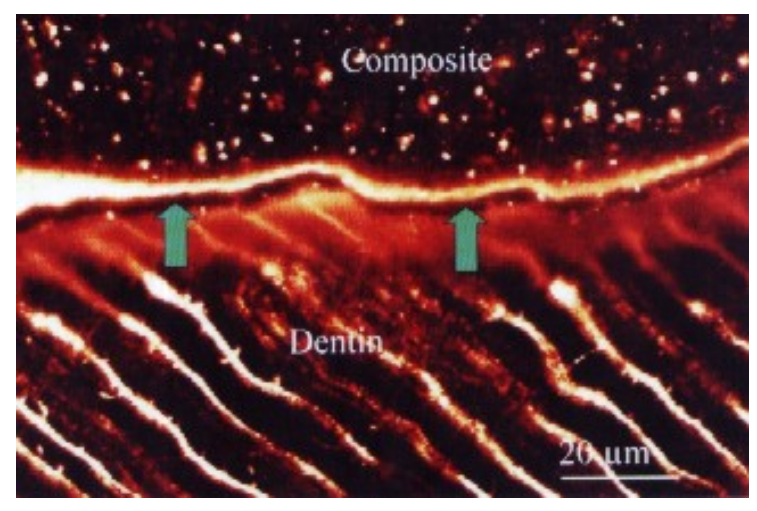

Figura 19 - Fotomicrografia da interface formada quando Prime \& Bond NT foi aplicado; observada em microscopia confocal ${ }^{126}$

Os autores afirmaram que o ressecamento da dentina deve ter influência na nanoinfiltração, dependendo da própria natureza do sistema adesivo aplicado. Concluíram que não somente o tipo de solvente contido no primer dos sistemas adesivos deve ser levado em consideração em relação à nanoinfiltração, mas também outros fatores como o tipo de monômero resinoso contido nos mesmos.

Em 2002, ABDALLA; GARCIA-GODOY ${ }^{1}$ avaliaram in vivo a interface adesiva formada quando da aplicação de quatro sistemas adesivos de frasco único. Os sistemas adesivos selecionados foram: Scotchbond 1, Syntac SC, One-Step e Prime \& Bond 2.1. Estes materiais foram aplicados na superfície plana dentinária de dentes anteriores humanos, os quais foram extraídos por razões protéticas. Um sistema adesivo convencional de três passos (Scotchbond MP) foi utilizado como controle. 
Após a aplicação do sistema adesivo, uma fina camada de resina composta foi aplicada, sendo o dente então imediatamente extraído. Todos os espécimes foram seccionados no longo eixo, sendo que em uma metade foram desproteinizados e descalcificados na interface com o intuito de visualizar a camada híbrida. As outras metades foram completamente dissolvidas para que se observassem os tags de resina. Os espécimes foram analisados em MEV em uma magnitude de 2.000x. Os autores observaram que todos sistemas adesivos analisados produziram camada híbrida e tags de resina na interface adesiva. O sistema adesivo controle apresentou imagens semelhantes, porém com uma camada híbrida mais espessa e com tags de resina mais longos. A espessura da camada híbrida quando se utilizou o Scotchbond 1 variou de 3 a $5 \mu \mathrm{m}$ e os tags de resina de 20 a $60 \mu \mathrm{m}$.

Ainda em 2002, D'ALPINO et al. ${ }^{25}$ avaliaram em MEV a adaptação interna de restaurações de resina composta às paredes cavitárias, as quais foram polimerizadas mediante à utilização de três diferentes técnicas de fotoativação. Cavidades classe $V$ foram preparadas nas faces vestibulares e linguais de 24 terceiros molares humanos, com margens localizadas acima e abaixo da junção amelo-cementária. As resinas compostas foram aplicadas em incremento único, sendo que os sistemas restauradores Single Bond/ Filtek A110 (3M) e Single Bond/ Z250 (3M) foram utilizados aleatoriamente nas faces vestibular e lingual no mesmo dente. As resinas compostas foram fotoativadas por meio de três técnicas: grupo 1convencional (600 mW/cm / 60 segundos); grupo 2- soft-start $\left(200 \mathrm{~mW} / \mathrm{cm}^{2} / 20\right.$ segundos + $600 \mathrm{~mW} / \mathrm{cm}^{2} / 40$ segundos); grupo 3- ativação por pulso $\left(200 \mathrm{~mW} / \mathrm{cm}^{2} /\right.$ 3 segundos +3 minutos espera $+600 \mathrm{~mW} / \mathrm{cm}^{2} / 47$ segundos). Foram feitas comparações dos resultados entre as resinas compostas utilizadas. As secções vestíbulo-linguais foram polidas, moldadas e replicadas, sendo os espécimes analisados em MEV, com um aumento de 1.000 vezes. A avaliação foi feita por escores, de acordo com a presença ou ausência de fendas. Nas Figuras 20 e 21 observa-se a presença de fendas na parede axial dos preparos. Da análise dos resultados, observou-se que não houve diferença significante entre os grupos avaliados. Os autores concluíram que a técnica de fotoativação e o tipo de resina utilizada não influenciaram na adaptação interna às paredes cavitárias. 

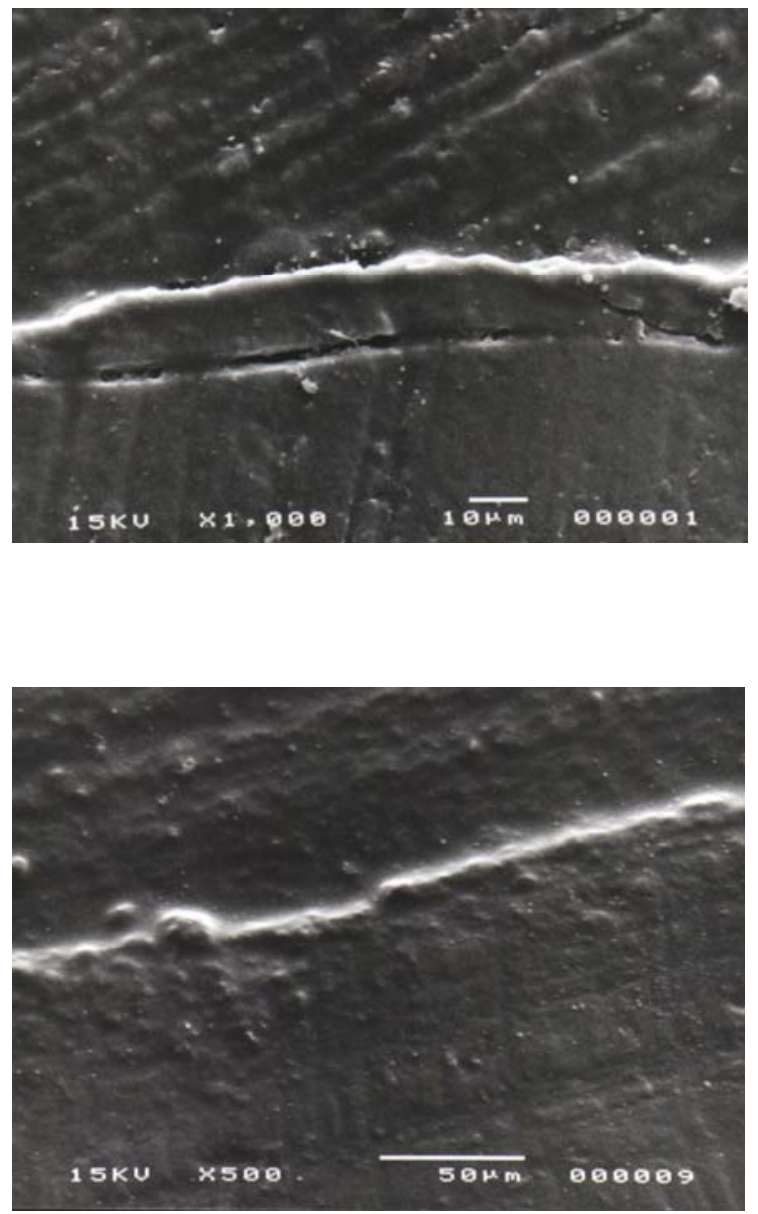

Figura 20 - Fotomicrografia em MEV da interface formada com fenda presente na parede axial quando Single Bond/Filtek A110 foram aplicados $^{25}$

Figura 21 - Fotomicrografia em MEV da interface livre de fenda na parede axial quando Single Bond/Filtek Z250 foram aplicados $^{25}$

ARRAIS; GIANNINI ${ }^{4}$, no mesmo ano, avaliaram a micromorfologia e a espessura da camada híbrida formada por diferentes sistemas adesivos utilizando MEV. Estes autores afirmaram que a formação da camada híbrida representa o principal mecanismo de união dos sistemas adesivos odontológicos. Os adesivos foram aplicados em superfícies planificadas de dentina na região oclusal de terceiros molares humanos, de acordo com as instruções dos fabricantes. Camadas de resina composta Z100 foram então inseridas sobre o sistema adesivo. Os dentes restaurados foram armazenados por um período de 24 horas a $37^{\circ} \mathrm{C}$. Os espécimes foram preparados e analisados em MEV em uma magnitude de 2.000x. Os sistemas adesivos mostraram formação de diferentes espessuras de camada híbrida ( $p$ < $0,05)$ e suas médias foram: Scotchbond MP Plus (SM), 7,41 $\mu \mathrm{m} \pm 1,24$; Single Bond 
(SB), 5,55 $\mu \mathrm{m} \pm$ 0,82; Etch \& Prime 3.0 (EP), 3,86 $\mu \mathrm{m} \pm 1,17$ e Clearfil SE Bond (CB), 1,22 $\mu \mathrm{m} \pm 0,45$. Na Figura 22, a seguir, observa-se a camada híbrida formada pela utilização do sistema adesivo Single Bond e a respectiva mensuração. Os resultados sugeriram que o adesivo convencional (SM), seguido do adesivo de frasco único (SB), mostraram a formação de camadas híbridas com maior espessura, enquanto os adesivos autocondicionantes EP e CB formaram camadas mais delgadas.

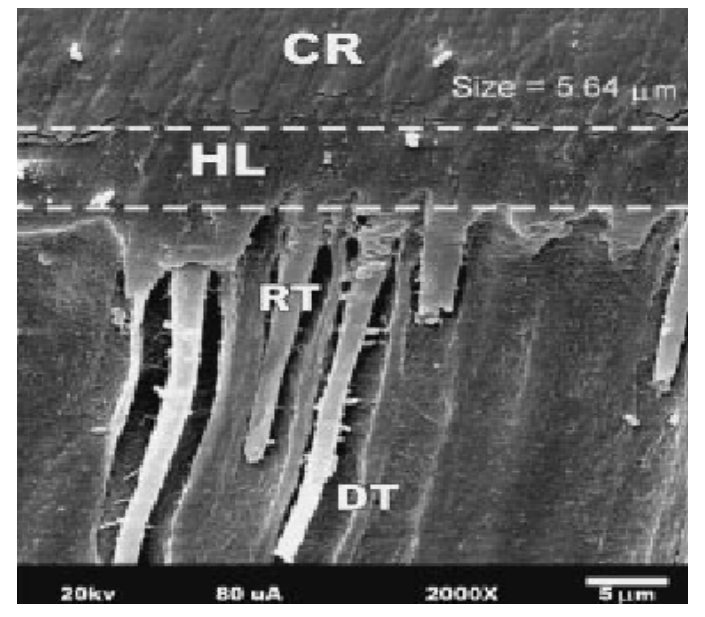

Figura 22 - Fotomicrografia da interface formada com Single Bond em MEV; destaca-se a espessura da camada híbrida ${ }^{4}$

Em 2003, PIOCH et al. ${ }^{122}$ avaliaram o efeito da aplicação de ácido hidrofluorídrico (HF) nas características morfológicas superficiais da dentina comparado à aplicação de ácido fosfórico (HP). Cinco grupos foram então compostos: (i) sem aplicação de ácido; (ii) HF 15 segundos, (iii) HP 15 segundos; (iv) HF 15 segundos seguido de HP 15 segundos; (v) HP 15 segundos seguido de HF 15 segundos. O sistema adesivo Optibond foi então aplicado sobre a dentina condicionada. Os dentes foram analisados em microscopia confocal através da adição de corante fluorescente (Rodamina B isothiocyanate; 0,1 \%) em uma magnitude de até 60x. Em relação aos túbulos dentinário, utilizou-se um MEV equipado com um aparelho de raios $X$ de energia dispersiva. A microscopia confocal mostrou que uma nítida camada híbrida pode ser observada somente no grupo iii. No grupo $\mathrm{v}$, a camada híbrida estava menos organizada comparada com o grupo iii. Nos grupos i, ii e iv não 
se encontraram formação de dentina hibridizada. Na Figura 23 observa-se nitidamente a formação da camada híbrida em microscopia confocal.

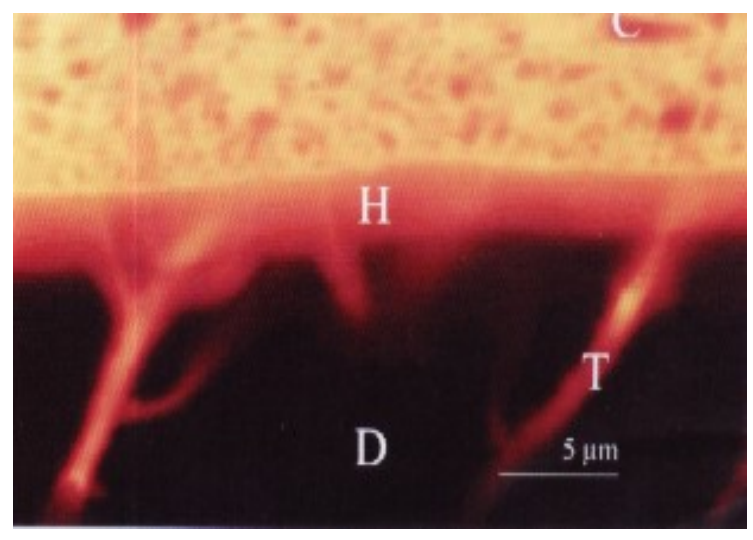

Figura 23 - Fotomicrografia da interface adesiva formada em microscopia confocal; destacam-se a presença da camada híbrida e de tags de resina $^{122}$

Da análise dos resultados em MEV, verificou-se que não haviam túbulos dentinários abertos nos grupos i, ii e iv. No grupo v somente alguns túbulos permaneceram abertos e, no grupo iii, a smear layer foi completamente removida e os túbulos ficaram abertos. A análise de raios $X$ mostrou que o fluoreto foi incorporado na superfície da dentina quando HF foi utilizado. Os autores concluíram que a aplicação de HF favorece a habilidade de ocluir os túbulos dentinários que foram abertos durante a aplicação de HP e que este ácido não é capaz de dissolver a smear layer.

Com o intuito de avaliar a capacidade de selamento dos túbulos dentinários pelos monômeros resinosos que permeiam as fibrilas de colágeno, WANG; SPENCER ${ }^{187}$, em 2003, avaliaram a qualidade e a estrutura molecular da interface dentina/adesivo formada em substrato dentinário úmido. Selecionaram-se seis terceiros molares, os quais foram desmineralizados, desidratados para, em seguida, receberem a aplicação do sistema adesivo Single Bond em condições consideradas ótimas. Parte dos espécimes recebeu a aplicação do mesmo sistema adesivo, porém em substrato umidecido. As interfaces adesivas foram coradas com o corante tricrômio de Goldner e foram analisadas em microscopia ótica e em espectroscopia Raman. Os resultados da histomorfologia e a espectroscopia da interface formada sugeriram que, quando o substrato era mantido úmido, a interface adesiva era 
formada por uma rede de fibrilas de colágeno porosa, infiltrada principalmente por monômeros HEMA que são instáveis na presença de água. A rede de colágeno e polímero formada não era impermeável e a composição desta rede era basicamente HEMA e fibrilas de colágeno, com uma menor contribuição do componente BisGMA. Os resultados sugeriram que o componente crítico BisGMA, que contribui para a formação de um maior número de ligações cruzadas, infiltrou apenas em uma parte da dentina intertubular desmineralizada que foi mantida úmida.

REIS et al. ${ }^{134}$, em 2004, avaliaram os efeitos de diferentes graus de umidade de superfície na durabilidade da adesão à dentina quando aplicados três sistemas adesivos compostos por diferentes solventes. Foram selecionados 45 terceiros molares humanos cujas superfícies dentinárias foram expostas e planificadas por abrasão. Após a delimitação da área de adesão $\left(52 \mathrm{~mm}^{2}\right)$, as superfícies foram condicionadas, lavadas e extensivamente secas com jatos de ar por 30s. Sistemas adesivos à base de etanol/ água (Single Bond - SB), acetona (One-Step - OS) e água (Syntac Single Component - SC) foram utilizados. Os mesmos foram aplicados sobre a superfície dentinária tanto seca ( $0 \mu$ de água) quanto re-umidecida com diferentes quantidades de água destilada $(2,5$ ou $4 \mu \mathrm{l})$, por $10 \mathrm{~s}$. Os adesivos foram fotoativados e a resina composta inserida em incrementos de $1 \mathrm{~mm}$. Após o armazenamento em água a $37^{\circ} \mathrm{C}$ por 24 horas, os dentes foram seccionados para a obtenção de palitos com $0,8 \mathrm{~mm}^{2}$. Os espécimes de cada dente foram divididos, armazenados em água a $37{ }^{\circ} \mathrm{C}$ e testes de resistência adesiva foram realizados imediatamente ou após 6 meses. A análise estatística revelou valores significantes para o grau de umidade, tempo de armazenamento e interações entre essas variáveis. Enquanto o SB e SC atingiram altos valores de resistência adesiva com 0 $\mu \mathrm{l}$ e 2,5 $\mu \mathrm{l}$ de água, o OS mostrou os maiores valores com $4 \mu \mathrm{l}$ de água. Independente do grau de umidade utilizado, foi observado redução nos valores de resistência adesiva após 6 meses de armazenamento do SB e OS, porém não do SC. Não foram observadas diferenças na resistência adesiva entre os espécimes armazenados por 24 horas e 6 meses, quando a umidade foi estabelecida nas condições extremas. Quando 2,5 $\mu \mathrm{l}$ de água foi utilizado, reduções significantes nos valores de resistência adesiva foram observados. Os autores concluíram que a resistência adesiva de sistemas adesivos compostos por diferentes solventes 
diminuiu gradualmente em função do tempo, independente do padrão de umidade utilizado no procedimento adesivo. Comentou-se que a utilização de monômeros relativamente mais hidrofóbicos na formulação dos sistemas adesivos poderia reduzir a degradação dos mesmos a longo prazo.

No mesmo ano, TAY et al. ${ }^{167}$ propuseram avaliar in vivo a efetividade de sistemas adesivos de frasco único em reduzir a permeabilidade dentinária. Os autores realizaram preparos cavitários em dentes humanos vitais que foram anestesiados como parte de um plano de tratamento para reabilitação oral. Selecionaram-se 4 adesivos: Single Bond, Excite DSC, Prime \& Bond NT e OneStep. Estes materiais foram aplicados na dentina após o condicionamento ácido. Antes e depois da aplicação do sistema adesivo foram realizadas moldagens com silicona. As moldagens foram metalizadas e analisadas em MEV para avaliar a transudação de fluido dentinário antes, imediatamente depois e após os procedimentos adesivos. Os autores verificaram que houve transudação na região próxima à polpa, independente do sistema adesivo utilizado. A transudação que ocorreu no controle, em que não se removeu a smear layer, foi comparativamente suave em comparação à que ocorreu nos dentes tratados com ácido e sistemas adesivos. Nas Figuras 24 e 25 observam-se fotomicrografias da análise da superfície da dentina em MEV, onde foi aplicado o Single Bond. Na Figura 24 observa-se o controle, sem a remoção da smear layer com presenças esparsas de gotículas (droplets) de transudado. Na Figura 25 observa-se a formação de gotículas de transudado em maior magnitude, mostrando que não houve completo selamento pela aplicação do adesivo. Os autores concluíram que os adesivos de frasco único, devido à falta de uma camada de adesivo mais hidrofóbica, se comportaram como membranas permeáveis após a polimerização. Eles permitiram a transudação contínua de fluido dentinário e não promoveram o vedamento hermético da dentina. Apesar de haver um fluxo relativamente lento de fluido dentinário, ele deve interferir na ótima polimerização do cimento resinoso dual ou químico utilizado para a cimentação das próteses. 


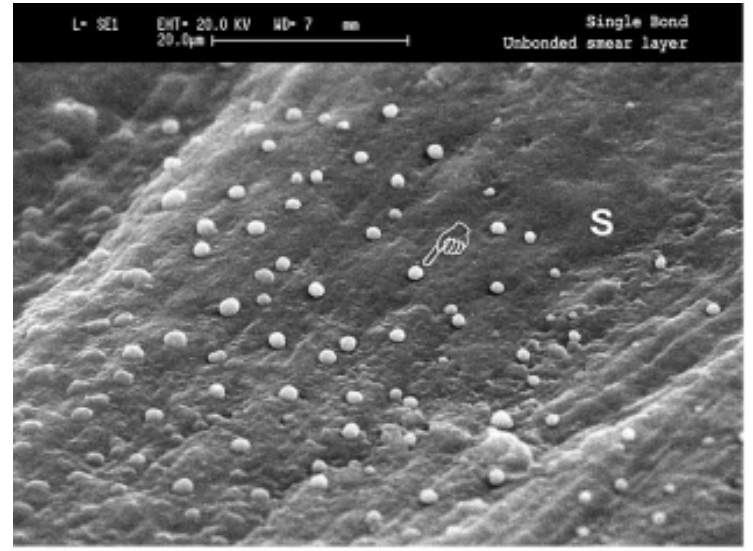

A

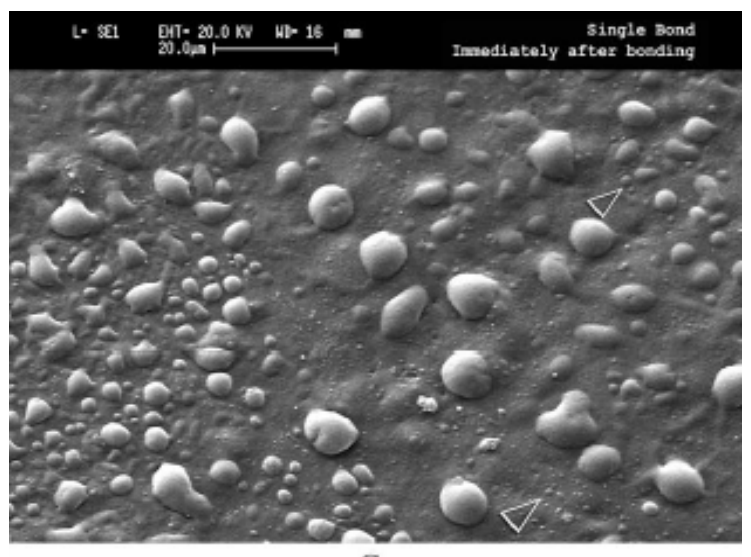

C
Figura 24 - Fotomicrografia em MEV da superfície de dentina sem remoção da smear layer ${ }^{16}$
Figura 25 - Fotomicrografia em MEV mostrando gotículas de transudato na dentina condicionada com ácido fosfórico/ aplicação Single Bond $^{167}$

PEUTZFELDT; ASMUSSEN ${ }^{119}$, em 2004, investigaram a influência da contração de polimerização, módulo de elasticidade, escoamento (viscosidade) e resistência adesiva na formação de fendas marginais em restaurações de resina composta in vitro. Neste trabalho, discutiu-se também o mecanismo da formação de fenda e a relação com a resultante das forças de contração de polimerização. Na Figura 26 está representada esquematicamente esta relação.

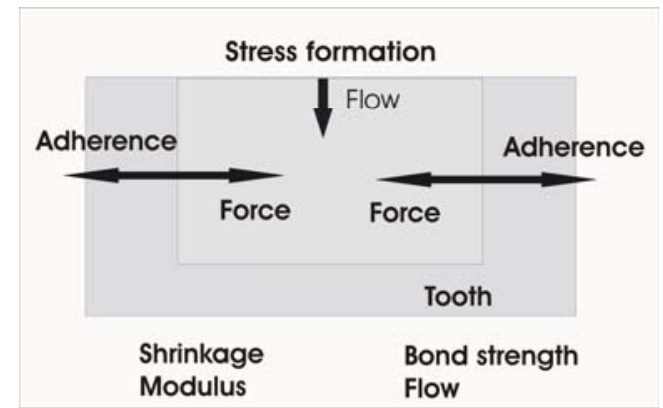

Figura 26 - Representação esquemática do mecanismo de formação de fendas devido à ação das forças de contração de polimerização ${ }^{119}$ 
Selecionaram-se onze resinas compostas comerciais. A formação de fendas em dentina foi mensurada com o auxílio de um microscópio ótico ao longo da margem de preparos cavitários cilíndricos (3,0 mm diâmetro $-1,5 \mathrm{~mm}$ profundidade), os quais receberam aplicação de um sistema adesivo e das diferentes resinas compostas. Os valores foram expressos em porcentagem de extensão em relação ao diâmetro da cavidade. Compararam-se os resultados dos testes mecânicos com a presença de fendas na interface dente/restauração. Diferenças significantes foram observadas quando se compararam os diferentes parâmetros. Foi observada uma correlação linear entre a capacidade de escoamento e a formação de fendas. A análise de regressão tri-dimensional demonstrou uma correlação significante entre contração de polimerização, viscosidade e formação de fendas. O maior coeficiente de correlação foi observado quando a primeira parte da contração de polimerização (de 0 a 10 segundos) foi descartada. Em outras palavras, o desenvolvimento da contração de polimerização ocorre com o tempo, ou seja, 10 segundos a 20 minutos após o início da fotoativação, que compreende a última parte da contração que ocorre depois de atingir o ponto gel (Figura 27).

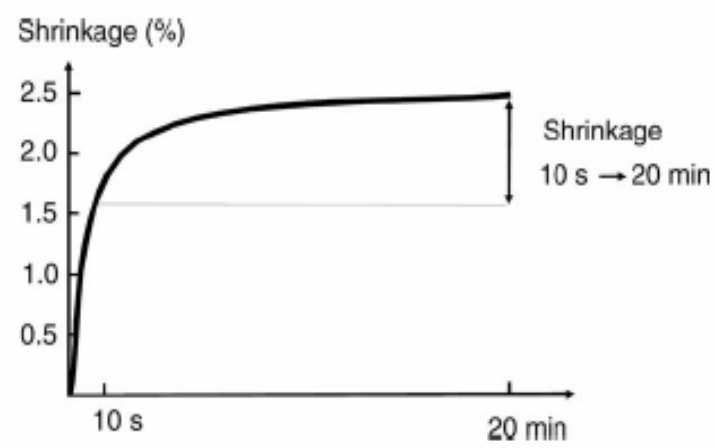

Figura 27 - Curva mostrando a relação contração $x$ tempo, demonstrando que a última parte da contração pós-gel é a que causa a formação de fendas ${ }^{119}$

Afirmou-se ainda que uma resina composta com um maior módulo de elasticidade deve causar uma maior resultante de forças e, assim, uma maior extensão de fendas comparada a uma resina com um menor módulo de elasticidade. Entretanto, neste estudo os autores não observaram influência do módulo flexural como um fator determinante da formação de fendas. O fato de não se encontrar correlação entre a 
resistência adesiva e a formação de fendas deveu-se à pequena variação nos valores do teste de cisalhamento. Os autores concluíram que os maiores determinantes para a formação de fendas em restaurações adesivas foram a contração de polimerização e a viscosidade das resinas compostas avaliadas.

Ainda em 2004, GIACHETTI et al. ${ }^{58}$ propuseram avaliar e revisar a interpretação atual dos tags de resina através de análise com MEV. Os autores afirmaram que os fundamentos da formação da camada híbrida dentina/sistema adesivo está bem estabelecida, porém a infiltração e permeação dos monômeros resinosos nos túbulos dentinários, que foram condicionados com ácido, permanece controverso. Para este estudo, os autores selecionaram oito terceiros molares hígidos que foram seccionados para a obtenção de uma superfície de dentina média a profunda. Os dentes foram condicionados com ácido fosfórico a $37 \%$ na forma de gel por 10 segundos e então lavados por 20 segundos. Aplicou-se o sistema adesivo Single Bond e fotoativou-se por 20 segundos. Em seguida, aplicou-se uma camada de resina flow (cerca de 0,5 mm) e também duas camadas ( $2 \mathrm{~mm}$ cada) de resina composta Z250 que foram fotoativadas. Os dentes foram seccionados longitudinalmente e divididos em 4 grupos de acordo com o tratamento de superfície: EA- aplicação do ácido etilenodiamino tetra-acético; PA3- ácido fosfórico; PA120ácido fosfórico mais hipoclorito de sódio; CA- ácido clorídrico e hipoclorito de sódio; CO- controle. Todos os espécimes foram analisados em MEV. Da análise da microscopia, observou-se que em todos os grupos ocorreram estruturas filamentosas com dezenas de $\mu \mathrm{m}$ de extensão. Alguns filamentos apresentaram terminações bifurcadas com estruturas ocas e paredes delgadas. Outros mostraram formato de $U$, indicando que eram amolecidos e flexíveis. Os resultados confirmaram a dificuldade na definição da natureza dos tags de resina utilizando-se as técnicas de preparos de espécimes atualmente empregadas. Os autores concluíram que as técnicas convencionais de microscopia eletrônica, que são usualmente utilizadas para detectar tags de resina, na verdade detectam estruturas filamentosas orgânicas, supostamente glicosaminoglicanas, que foram resistentes quando se utilizou uma técnica de preparo convencional para análise dos espécimes. 0 componente orgânico mostrou ser compatível com uma estrutura contida no interior dos túbulos dentinários (lamina limitans). Os resultados deste estudo não 
comprovaram que os tags de resina são totalmente formados de glicosaminoglicanas, sendo que também não há evidências de que são totalmente constituídos de adesivo.

\section{3- Resistência de União Adesiva}

FUSAYAMA et al. ${ }^{56}$, em 1979, avaliaram a resistência adesiva ao esmalte dentário, à dentina normal e à dentina afetada por cárie através da aplicação de sistemas adesivos com ou sem condicionamento ácido prévio destas superfícies. Selecionaram-se incisivos para avaliação em esmalte e molares para avaliação em dentina. As superfícies foram condicionadas com ácido fosfórico (40 \%) por 60 segundos, lavadas e secas. Após o condicionamento, aplicou-se o sistema adesivo Clearfil Bond System-F em associação com as resinas Clearfil, Adaptic, Concise e Palakav. O teste de resistência adesiva utilizado foi de tração em um dispositivo desenvolvido pelos autores. Da análise dos resultados, observou-se que a resistência adesiva ao esmalte que recebeu o condicionamento ácido subiu de 26,3 $\mathrm{Kg} / \mathrm{cm}^{2}$ para $111,5 \mathrm{Kg} / \mathrm{cm}^{2}$. Em relação à dentina, houve um aumento que passou de $16,8 \mathrm{Kg} / \mathrm{cm}^{2}$ para $62,3 \mathrm{Kg} / \mathrm{cm}^{2}$. Demonstrou-se, desta forma, que a resistência adesiva dos materiais restauradores aos substratos dentários poderia ser aumentada significativamente pela utilização do condicionamento ácido da superfície.

DAVIDSON; DE GEE; FEILZER ${ }^{31}$, em 1984, estudaram a influência das forças produzidas pela contração de polimerização em duas resinas compostas em função do tempo de polimerização e da adesão à dentina. Para isso, utilizaram as resinas Silar e Silux que foram aplicadas em superfícies retangulares planas de dentina de dentes bovinos. O sistema adesivo aplicado foi o Scotchbond e os dentes foram então submetidos ao teste de resistência adesiva. Ainda, durante a aplicação da resina composta, a mesma foi posicionada em um tensilômetro com o intuito de mensurar as forças de contração de polimerização. Além disso, a resistência adesiva foi mensurada em diferentes tempos após o início da polimerização do material. Os valores de resistência adesiva variaram de 0 a 7,8 MPa, comparados aos valores de contração que foram de 0 a 2,4 MPa. Adicionalmente, os autores avaliaram a 
microinfiltração marginal em cavidades de classe $V$, as quais foram também preparadas em dentes bovinos. As mesmas resinas compostas foram aplicadas nesses preparos e os espécimes foram imersos em azul de metileno por dez minutos. Verificou-se que nas margens de esmalte a infiltração foi mínima, diferente do que ocorreu em dentina, onde a maioria das paredes apresentou-se infiltrada. Afirmou-se que, quando a contração é restrita somente a uma direção, a adesão é efetiva, mas como se trata de uma cavidade tridimensional, a resultante das forças deve se compensada, de certa forma, pelo escoamento do material. No caso de cavidades classe $\mathrm{V}$ verificou-se que $2 / 3$ da restauração estava em contato com a estrutura dentária e que, devido a este fato, poderiam ser desenvolvidas forças de contração com uma magnitude de $20 \mathrm{MPa}$. Desta forma, os autores afirmaram que a aplicação de uma resina composta em uma superfície plana ou em cavidades rasas seria mais favorável para se obter uma união durável à dentina. Concluíram que, idealmente em dentina, resinas compostas com baixa contração e cavidades menos complexas seriam ideais para a obtenção de um selamento marginal duradouro e altos valores de resistência adesiva.

Com o objetivo de avaliar a resistência adesiva à dentina em diferentes profundidades dentinárias e tratamentos superficiais, TAO; PASHLEY ${ }^{165}$, em 1988, selecionaram terceiros molares hígidos e não irrompidos que foram seccionados perpendicularmente ao longo eixo, objetivando eliminar o esmalte e expor a superfície dentinária. Criou-se então uma smear layer em dentina através de lixas de papel (A) ou com brocas cone-invertido (B). Desta forma, obtiveram-se 5 grupos experimentais: 1- água por um minuto; 2- tratamento com ultra-som por 1 hora; 3tratamento com solução de EDTA a 0,2 \% por 1 minuto; 4- solução de ácido cítrico a $6 \%$ por 1 minuto e 5 - ácido fosfórico a $37 \%$ por 15 segundos. Após o tratamento de superfície, os dentes foram lavados com água e secos com jatos de ar por 5 segundos. Aplicou-se o sistema adesivo Scotchbond e duas camadas da resina composta Silux. Avaliou-se então a resistência adesiva ao cisalhamento. Da análise dos resultados, verificou-se que nos casos em que a smear layer foi criada com lixa os valores de resistência adesiva foram significantemente maiores que as criadas por brocas. Os maiores valores de resistência foram encontrados no grupo 1 (5,7 
$\mathrm{MNm}$ ). Os demais grupos apresentaram valores significantemente menores (de 1,0 a 4,2 MNm).

Em 1992, KANCA ${ }^{86}$ avaliou a resistência adesiva à dentina utilizando condicionamento com diferentes ácidos e umidades de superfície. Selecionaram-se 60 molares humanos que foram desgastados com lixa de granulação 320 . Os dentes receberam três tipos de tratamento: 1- aplicação do primer, aplicação do sistema adesivo (All Bond 2) e resina composta sem remoção da smear layer; 2condicionamento com ácido fosfórico a 10 \% por 30 segundos, aplicação do All Bond 2 e resina composta; 3- condicionamento com ácido fosfórico a $32 \%$ por 20 segundos, aplicação do All Bond 2 e resina composta. Em relação à umidade da dentina, repetiram-se os grupos utilizando-se dentina seca e úmida. Avaliou-se a resistência adesiva ao cisalhamento. Os maiores valores de resistência foram observados em dentina úmida e após o condicionamento ácido (34,3 e 36,5 MPa). Os menores valores foram encontrados em dentina seca e na ausência de condicionamento ácido (11,7 MPa).

Por sua vez, FINGER; INOUE; ASMUSSEN ${ }^{54}$, em 1994, objetivaram avaliar a espessura da camada híbrida e a relação com a resistência adesiva decorrente do tratamento dentinário com soluções ácidas de diferentes $\mathrm{pH}$. Para isso, selecionaram dentes humanos que tiveram a face proximal exposta pelo desgaste realizado com lixas de granulação variando de 240 a 600. A superfície dentinária foi condicionada com Gluma 2000-1 (ácido oxálico; pH 1,25, com nitrato de alumínio e glicina), com uma solução experimental (ácido oxálico; $\mathrm{pH} 3,6$, com nitrato de alumínio e glicina) e com Gluma 2 Cleanser (EDTA; pH 7,4). Após o tratamento da superfície, lavou-se e secou-se a dentina previamente à aplicação dos sistemas adesivos e da resina composta. Realizou-se então o teste de resistência adesiva ao cisalhamento que foi medido em MPa. Verificou-se, através da análise dos resultados, que não houve diferença significante em relação aos tratamentos da dentina quando se utilizaram as soluções ácidas com diferente pH. Verificou-se ainda uma correlação entre a espessura da camada híbrida formada e a resistência adesiva. Foi também observado que a espessura da camada híbrida está relacionada com o grau de descalcificação da dentina, que por sua vez deve favorecer a infiltração do adesivo nesta área. 
Um estudo objetivando testar a hipótese de que não havia relação entre a área de superfície aderida e a resistência de união à dentina foi realizado por SANO et al. ${ }^{146}$, em 1994. Os autores utilizaram terceiros molares humanos que tiveram o esmalte oclusal removido e a superfície dentinária exposta. Foram realizados os procedimentos adesivos em dentina com a aplicação de camadas de resina composta sobre o adesivo. Os dentes foram seccionados obtendo-se espécimes com a mesma extensão de dentina e resina composta. Estes espécimes foram desgastados na região da interface adesiva para que se obtivessem regiões de interface com dimensões reduzidas. Realizaram-se então os testes de tração nestes espécimes. Os resultados demonstraram que os valores de resistência adesiva foram inversamente proporcionais à área aderida. Para uma área de $0,4 \mathrm{~mm}^{2}$, o sistema adesivo Clearfil Liner Bond apresentou valores médios de resistência de 55 MPa, para o sistema adesivo Scotchbond MP, 38 MPa e para o ionômero de vidro Vitremer, $20 \mathrm{MPa}$. Os autores observaram ainda que, utilizando pequenas áreas adesivas, todas as fraturas aconteceram na interface adesiva. Como conclusão, descreveu-se que esse novo método, denominado microtração, permitia medir os valores reais de resistência adesiva sem que houvesse falhas coesivas em dentina, além de possibilitar a realização de múltiplas avaliações no mesmo dente.

Em 1995, PASHLEY et al. ${ }^{112}$ avaliaram os testes de resistência adesiva e a validade dos valores obtidos nos mesmos. Relatou-se que na maioria dos testes de resistência, devido ao fato dos valores serem na ordem de 20 a $30 \mathrm{MPa}$, a resultante das forças muitas vezes não ocorre na interface adesiva, sendo que falhas coesivas podem acontecer em dentina ou em resina composta. Desta forma, destacou-se a importância da realização do teste de microtração que fornecia valores de união de até $70 \mathrm{MPa}$ e uma maior porcentagem de falhas na área adesiva. Dentre as vantagens do teste de microtração, os autores destacaram: possibilidade da avaliação da resistência adesiva em várias regiões, possibilidade de se obter valores a partir de vários espécimes de um mesmo dente; maior porcentagem de falhas adesivas do que coesivas; obtenção de maiores valores de resistência, comparados aos testes tradicionais; e a possibilidade de se avaliar a área aderida em MEV. Os autores mencionaram ainda algumas desvantagens da técnica: necessidade de equipamentos especiais; dificuldade da preparação dos espécimes; dificuldade da 
mensuração dos valores quando inferiores a $5 \mathrm{MPa}$, além da possibilidade de desidratação dos espécimes.

YOSHIKAWA et al. ${ }^{197}$, em 1999, testaram a hipótese de que a resistência de união da resina composta em cavidades tipo caixa (Classe I) seria reduzida em função da configuração cavitária e da profundidade dentinária, utilizando o teste de microtração. Em um grupo foram utilizados terceiros molares, nos quais um corte ao nível do esmalte oclusal objetivou a remoção do mesmo e a exposição de dentina superficial $(C=1)$. Em outro grupo, cavidades de $3 \mathrm{~mm}$ de comprimento por $4 \mathrm{~mm}$ de largura foram preparadas com uma profundidade de $2 \mathrm{~mm}$ abaixo da superfície planificada $(\mathrm{C}=3)$. Para realizar a adesão em dentina profunda sem paredes, ou seja, em dentina plana $(C=1)$, as paredes cavitárias de outro grupo foram removidas, pela secção das paredes verticais da Classe I simulada. Os adesivos utilizados foram o Clearfil Liner Bond II System (LBII), One-Step (OS) e Super-Bonded D Liner (DL), seguidos das restaurações com a resina composta (Clearfil Photo Posterior). Após o armazenamento em água por 24 horas, os dentes foram seccionados em fatias verticais $(0,7 \mathrm{~mm}$ de espessura), paralelas ao longo eixo do dente e, em seguida, montadas no aparelho de teste para serem submetidas à tração de $1 \mathrm{~mm} / \mathrm{min}$. na máquina de teste universal. De acordo com os resultados, pôde-se observar que todos os grupos apresentaram alta resistência de união em dentina superficial, mas o OS e DL apresentaram uma significante queda na resistência em dentina profunda com $C=1$. Quando o fator $C$ foi aumentado para 3, houve uma queda na resistência de união para todos os materiais (21 a $35 \%$ ), mas estatisticamente significante somente para o DL. Concluíram que alguns sistemas adesivos não se aderem adequadamente em dentina profunda, sendo mais susceptíveis às tensões de contração desenvolvidas em cavidades que apresentam alto fator $C$.

Em 1999, com o intuito de observar se havia relação entre a resistência adesiva e a nanoinfiltração, PAUL et al. ${ }^{114}$ selecionaram nove terceiros molares que tiveram o esmalte oclusal removido para que se expusesse a dentina superficial. Esta foi condicionada com ácido fosfórico a $35 \%$, utilizando-se diferentes tempos de aplicação (15, 30, 60 segundos). O sistema adesivo Single Bond foi aplicado de acordo com instruções do fabricante e a resina composta Z100 inserida em camadas. Os dentes foram armazenados por 24 horas e seccionados para que se 
obtivessem espécimes com 0,7 $\mathrm{mm}$ de espessura. Alguns espécimes foram selecionados para serem armazenados em ambiente seco, outros em ambiente úmido e outros, ainda, para serem imersos em nitrato de prata a $50 \%$ por 1 hora. Todos os espécimes foram analisados em MEV. Os resultados mostraram que, aumentando-se o tempo de aplicação do ácido fosfórico, houve uma redução na resistência adesiva quando os espécimes foram armazenados em ambiente úmido, mas valores semelhantes quando corados com nitrato de prata. Houve aumento da deposição de prata quando se utilizaram tempos maiores de condicionamento. Os resultados sugeriram que um sobre condicionamento não mostrou, a curto prazo, um efeito negativo em termos de resistência para o adesivo Single Bond. Entretanto, a deposição de prata, dependendo do tempo de condicionamento, deve causar preocupação em termos de estabilidade das uniões adesivas a longo prazo.

Por sua vez, PRICE et al. ${ }^{132}$, em 2000 , compararam os resultados de resistência adesiva quando utilizadas a fotoativação convencional e com modulação da intensidade inicial da luz para fotoativar a resina composta após 10 minutos e 24 horas. Na forma contínua, a resina composta foi polimerizada por 60 segundos com densidade de potência de $640 \mathrm{~mW} / \mathrm{cm}^{2}$, enquanto que com modulação a resina foi polimerizada por 10 segundos a $120 \mathrm{~mW} / \mathrm{cm}^{2}$ e 50 segundos a $640 \mathrm{~mW} / \mathrm{cm}^{2}$. Foram utilizados três sistemas adesivos comerciais: Single Bond (SB), Prime \& Bond 2.1 (P\&B) e EBS. Após a aplicação dos mesmos, camadas de resina composta foram inseridas para posterior avaliação da resistência adesiva ao cisalhamento. Os resultados mostraram que, quando se utilizou alta densidade de potência, os valores foram significantemente maiores comparados aos obtidos com a modulação da intensidade inicial. Os resultados após 24 horas foram significantemente maiores quando comparados aos valores após 10 minutos. Ainda, verificou-se que os valores apresentados quando se utilizaram os adesivos SB e P\&B foram significantemente maiores que os apresentados pelo EBS. Os autores concluíram que a utilização de baixa intensidade de luz por 10s, seguida pela alta intensidade por 50s, não apresentou efeito benéfico em relação à resistência adesiva ao cisalhamento.

Com o intuito de avaliar se havia uma correlação entre a resistência adesiva e a nanoinfiltração, PEREIRA et al. ${ }^{116}$, em 2001, utilizaram sistemas adesivos totaletch e primers com monômeros acídicos. Os autores selecionaram dez terceiros 
molares que tiveram o esmalte superficial removido para que se expusesse a dentina superficial plana, que, por sua vez, foi polida com lixa de granulação 600 em água corrente. Os sistemas adesivos selecionados foram o Clearfil Liner Bond $2 \mathrm{~V}$ e o Single Bond, os quais foram aplicados à superfície dentinária de acordo com instruções dos fabricantes. Em seguida, aplicaram-se camadas da resina composta Clearfil AP-X, sendo os espécimes armazenados por 24 horas a $37^{\circ} \mathrm{C}$. Os dentes foram seccionados para que se obtivessem espécimes com $7 \mathrm{~mm}$ de espessura, os quais foram avaliados pelo teste de microtração. Selecionaram-se aleatoriamente espécimes para serem imersos em nitrato de prata a $50 \%$ por uma hora, a fim de que se analisasse a nanoinfiltração. Os espécimes fraturados foram avaliados em microscopia confocal e, posteriormente, analisados em MEV. Os resultados mostraram que não houve diferença significante entre os valores apresentados de resistência adesiva quando se utilizaram os diferentes adesivos. No entanto, a resistência adesiva dos espécimes que foram imersos em nitrato de prata foi significantemente maior. Os autores atribuíram este aumento ao baixo $\mathrm{pH}$ apresentado pela solução de nitrato de prata, que causou uma redução no módulo de elasticidade dos espécimes. Sendo assim, uma maior força foi necessária para se promover a fratura. Não se observou correlação entre a resistência adesiva e a nanoinfiltração em ambos os adesivos.

A contração das resinas compostas ocorre durante a polimerização, afetando suas propriedades físicas e a integridade marginal. Considerando que a fotoativação gradual parece minimizar a contração desses materiais, CALDWELL; KULKARNI; TITLEY $^{16}$, em 2001, compararam a resistência adesiva ao cisalhamento de várias espessuras de resina composta polimerizadas através de duas diferentes técnicas de fotoativação. Terceiros molares foram incluídos em moldes e dois sistemas adesivos (Scotchbond MP ou Single Bond) foram aplicados, de modo que espécimes de 1,5; 3,0 e 4,5 $\mathrm{mm}$ de resina composta (Z100) foram confeccionados para cada sistema adesivo. Também, foram utilizados diferentes métodos de fotoativação para cada espessura de material com o aparelho Elipar Highlight (ESPE): 10 segundos a $150 \mathrm{~mW} / \mathrm{cm}^{2}+30$ segundos a $700 \mathrm{~mW} / \mathrm{cm}^{2}$ ou 40 segundos a $700 \mathrm{~mW} / \mathrm{cm}^{2}$. Posteriormente às restaurações, os dentes foram armazenados em água a $37{ }^{\circ} \mathrm{C}$ por 7 dias. Então, o teste de resistência adesiva ao cisalhamento foi realizado e revelou 
que as diferentes espessuras de resina composta e métodos de fotoativação não mostraram diferença significante, para ambos os sistemas adesivos utilizados. Exceção foi observada com 4,5 mm de espessura da resina composta, associada ao Single Bond, a qual apresentou significante menor resistência adesiva. Os resultados revelaram que, com maiores espessuras de resina composta, existe uma maior tendência a ocorrer falhas adesivas/coesivas. Também, não foram verificadas diferenças na resistência adesiva quando espessuras de 1,5 mm e 3,0 mm foram fotoativadas por ambos os métodos. Os autores concluíram que a fotoativação do material através a técnica gradual parece não oferecer vantagens sobre a técnica convencional e que os incrementos podem ser fotoativados por ambas as técnicas, desde que não ultrapassem 2,0 mm de espessura.

Ainda no mesmo ano, ÖESTERLE et al. ${ }^{104}$ compararam a resistência adesiva de brackets ortodônticos à superfície do esmalte utilizando fontes de luz PAC e QTH para fotoativar diferentes sistemas adesivos. As fontes de luz utilizadas foram: Apollo 95E (PAC) e Optilux 401 Light (QTH). Três sistemas adesivos foram utilizados para fixar os brackets ao esmalte de dentes bovinos, os quais foram fotoativados por 40 segundos com QTH e por 3, 6 e 9 segundos com PAC, sendo que a resistência adesiva foi avaliada após 30 minutos e 24 horas. Os resultados mostraram que os valores de resistência adesiva foram melhores quando maiores tempos de exposição foram utilizados pelo PAC para fotoativar os sistemas adesivos. Apesar disso, não se observou diferença estatística nos valores de resistência adesiva quando se utilizou PAC e QTH, independente do tempo de avaliação.

Ainda em 2001, NUNES; SWIFT JR; PERDIGÃO ${ }^{103}$ avaliaram a influência da composição do adesivo (solvente e partículas de carga) na resistência adesiva à dentina, através do teste de microtração. Utilizaram-se 15 terceiros molares, os quais foram desgastados para exposição da dentina superficial e polidos com lixas de granulação 600. A dentina foi condicionada com ácido fosfórico a $37 \%$ por 15 segundos, lavada e seca com papel absorvente. Os seguintes adesivos foram aplicados segundo as instruções dos fabricantes: Single Bond (SB), Single Bond com carga (SBE) Prime \& Bond NT (NT), Prime \& Bond NT sem carga (NTE), e One Coat Bond com carga (OC). Cada sistema adesivo foi aplicado em 3 dentes com posterior confecção de um cilindro de resina composta (Tetric Ceram) na superfície 
oclusal. Após 24 horas de armazenamento em água a $37{ }^{\circ} \mathrm{C}$, cada dente foi seccionado para a obtenção de espécimes com 0,35 a $0,45 \mathrm{~mm}^{2}$, os quais foram submetidos ao teste de microtração. Os resultados revelaram que para os adesivos com carga, a média de resistência adesiva variou de 48,2 MPa (NT) a 57,9 MPa (SBE). A média dos valores de resistência adesiva foi de 75,9 MPa e 38,7 MPa para os adesivos sem carga SB e NTE, respectivamente. O SB sem carga teve média significantemente maior de resistência adesiva comparado a sua versão experimental com carga. O sistema adesivo à base de etanol (SB) apresentou média significantemente maior de resistência adesiva que o OC (à base de solvente não volátil) e o NT (à base de acetona). Segundo os autores, o SB contém água, o que deve ter facilitado a penetração da resina nas fibrilas de colágeno, independente da condição de umidade da dentina. O SB também apresentou maior número de falhas coesivas na resina composta comparado aos demais adesivos. Segundo os autores, os sistemas adesivos de frasco único testados não propiciaram maiores valores de resistência adesiva com a adição de partículas de carga. O adesivo à base de etanol pode ser relativamente menos sensível ao grau de umidade da superfície dentinária.

A avaliação da resistência adesiva formada quando da aplicação de quatro sistemas adesivos com diferentes composições foi realizada por CARRILHO et al. ${ }^{17}$, em 2002, por meio do teste de microtração. Selecionaram-se 12 terceiros molares humanos, os quais tiveram o esmalte oclusal removido para exposição de uma superfície plana de dentina. Os dentes foram aleatoriamente divididos em 4 grupos, de acordo com o sistema adesivo e a resina composta empregados: G1- Single Bond + P60 (SB); G2- Bond 1 + Surefil (B1); G3- Prime \& Bond NT + Alert (NT); G4Prime \& Bond $2.1+\mathrm{TPH}(\mathrm{PB})$. Após o armazenamento em água destilada por 24 horas a $37{ }^{\circ} \mathrm{C}$, os dentes foram seccionados para obtenção de espécimes com 0,8 $\mathrm{mm}^{2}$ de área e $10 \mathrm{~mm}$ de comprimento. Os mesmos foram submetidos ao teste de microtração. Os resultados demonstraram não haver diferença significante entre os valores médios de resistência obtidos pelos quatro adesivos: SB (35,6 MPa \pm 15$)$, B1 $(33,3 \mathrm{MPa} \pm 11,6)$, NT $(28,0 \mathrm{MPa} \pm 8,50)$, PB $(34,8 \mathrm{MPa} \pm 12,4)$. Com relação ao percentual de espécimes fraturados, o SB foi significantemente melhor, com apenas $8 \%$ de falhas precoces, seguido do B1 (64\%), NT (52 \%) e PB (44\%). Considerando-se todos os espécimes, o modo de fratura predominante foi adesivo 
(63\%), seguido do misto (34\%), coesivo em resina (2\%) e coesivo em dentina (1 $\%)$. Os autores concluíram que o SB demonstrou, nas condições do estudo, menor sensibilidade por apresentar baixo percentual de espécimes fraturados precocemente, embora a resistência observada tenha sido semelhante para todos os sistemas adesivos.

TAKAHASHI et al. ${ }^{162}$, em 2002, propuseram avaliar se havia uma relação entre a resistência adesiva à dentina e as propriedades mecânicas dos sistemas adesivos polimerizados. Para isso, selecionaram-se 20 terceiros molares recém extraídos que tiveram o esmalte coronário removido, expondo-se a dentina que, por sua vez, foi polida com lixa de granulação 600 . Selecionaram-se quatro marcas comerciais de sistema adesivo (Clearfil SE Bond; UniFil Bond; Tokuso Mac-Bond II; e Imperva Fluoro Bond) que foram aplicados à dentina seguindo-se as instruções dos fabricantes. Em seguida, camadas de resina composta foram inseridas e os espécimes armazenados em água a $37{ }^{\circ} \mathrm{C}$ por 24 horas. Posteriormente, os mesmos foram seccionados e submetidos ao teste de microtração, sendo que as superfícies foram analisadas em MEV. Para o teste de propriedades mecânicas, prepararam-se espécimes polimerizados dos diferentes adesivos com $7 \mathrm{~mm}$ de espessura, sendo então avaliada a resistência adesiva máxima. Foram ainda avaliados a nano-dureza e o módulo de Young. Da análise dos resultados, verificouse que não houve diferença significante em relação à resistência adesiva e à resistência adesiva máxima quando se compararam os diferentes adesivos utilizados. Entretanto, a nano-dureza e o módulo de Young dos adesivos Clearfil SE Bond e Imperva Fluoro Bond foram significantemente maiores do que os apresentados pelos adesivos UniFil Bond e Tokuso Mac-Bond II. Houve uma forte correlação entre resistência adesiva e a resistência adesiva máxima dos adesivos $\left(R^{2}=0,77\right)$, mas não se observou correlação com a nano-dureza ou com o módulo de Young. As imagens obtidas em MEV mostraram fraturas mistas com a combinação de fraturas coesivas e de interface. Os autores concluíram que para os quatro sistemas adesivos avaliados os resultados de resistência adesiva foram similares e se correlacionaram com a resistência adesiva máxima dos mesmos.

Em 2002, NIKAIDO et al. $^{99}$ propuseram avaliar a resistência adesiva à dentina aplicando-se diferentes sistemas adesivos em cavidades classe I que 
receberam aplicação de carga oclusal e ciclagem térmica. Selecionaram-se 12 terceiros molares que receberam preparos cavitários classe I $(4,0 \times 2,0 \times 3,0 \mathrm{~mm}$ de profundidade). Foram utilizadas duas marcas comerciais de sistema adesivo: Clearfil SE Bond (SE) e Single Bond (SB), os quais foram aplicados de acordo com instruções dos fabricantes. Os dentes foram restaurados e armazenados por uma semana, sendo que alguns dentes foram sujeitos a compressão por 50.000 ciclos e ciclagem térmica de 5 a $55{ }^{\circ} \mathrm{C}$ por 625 ciclos. Realizou-se o teste de resistência adesiva à microtração. Os resultados mostraram que os valores de resistência adesiva foram influenciados pelo tipo de sistema adesivo aplicado e não pela ciclagem de carga. Os valores apresentados pelo adesivo SE $(30,5 \mathrm{MPa} \pm 12,8$ no controle) foram significantemente maiores que os do SB (5,1 MPa $\pm 9,2$ no controle). Metade dos espécimes de SB descolou durante o preparo dos espécimes para microtração, sendo que microscopicamente observaram-se estruturas encapsuladas sugerindo que o fenômeno de over-wet ocorreu no assoalho da cavidade. Os autores concluíram que SE mostrou excelente resistência adesiva, a qual foi muito maior que os valores apresentados pelo SB, que mostrou maior sensibilidade da técnica de aplicação.

Com o objetivo de avaliar a resistência adesiva à dentina superficial e profunda, TOLEDANO et al. ${ }^{175}$, em 2003 , utilizaram diferentes tipos de sistemas adesivos. Foram selecionados terceiros molares humanos cujas coroas foram seccionadas tanto perto da junção amelo-dentinária quanto próximo à polpa, com o intuito de expor as superfícies dentinárias superficiais ou profundas. Os dentes foram divididos em 5 grupos de 10, sendo que cinco sistemas adesivos foram utilizados segundo as instruções dos fabricantes: Single Bond/ sem carga (SB), Prime \& Bond NT/ com carga (NT), Excite/ com carga (EX); Clearfil SE Bond/ com carga (CSE) e Etch \& Prime 3.0/ sem carga (EP). Em seguida, a resina composta Z 250 foi inserida em incrementos. Após o armazenamento em água por 24 horas a $37^{\circ} \mathrm{C}$, os dentes foram seccionados para a obtenção de espécimes com $1 \mathrm{~mm}^{2}$, os quais foram submetidos ao teste de microtração. As interfaces adesivas também foram examinadas pelo MET e a nanoinfiltração pela deposição de íons prata. A análise dos resultados revelou que o SB, NT e CSE comportaram-se de forma similar quando aplicados à dentina superficial; o valor mais baixo foi obtido com o EP. Na 
dentina profunda, os maiores valores de resistência adesiva foram observados com o CSE e NT. Os valores de resistência adesiva do NT e EX foram significantemente maiores na dentina profunda quando comparada à dentina superficial. Os adesivos SB, CSE e EP mostraram resistência adesiva similar em ambas profundidades dentinárias. O sistema adesivo Single Bond apresentou valores de resistência adesiva em torno de $41 \mathrm{MPa}$ tanto em dentina superficial quanto em profunda. A extensa nanoinfiltração observada no SB pode ter ocorrido devido à incompleta infiltração da resina. A água residual pode ter impedido a polimerização do adesivo ou formado hidrogéis porosos, com água, juntamente com os componentes do HEMA. A nanoinfiltração manifestou-se de forma variável dentro de todas as camadas híbridas examinadas. Os autores concluíram que a resistência adesiva à dentina é dependente tanto do substrato quanto do adesivo. Os sistemas autocondicionantes mostraram comportamentos similares em ambas profundidades dentinárias. Evidenciou-se a eficiência dos adesivos com carga quando aplicados em dentina profunda. Contudo, estudos clínicos a longo prazo são recomendados para avaliações adicionais da eficiência de tais adesivos em dentina sadia e cariada.

Em 2004, VERSLUIS et al. ${ }^{184}$ realizaram um estudo utilizando metodologia com elemento finito tridimensional, no qual propuseram calcular a resultante de forças da contração de polimerização que é transmitida ao dente e às margens cavitárias em diferentes configurações de cavidade. Para isso, simularam três configurações de cavidade em molares, sendo que a propriedade e comportamento de certas resinas compostas comerciais foram previamente determinadas durante 0 processo de polimerização das mesmas. Os padrões de deformação oclusal e a tensão residual no dente, na restauração e na interface dente/restauração foram calculados utilizando-se um modelo de polimerização baseado no conceito da contração pós-gel. Na Figura 28 observa-se um comparativo dos resultados de tensão na interface adesiva nas diferentes configurações cavitárias. Da análise dos resultados, verificou-se que a resultante da contração variou com a configuração e com o tamanho das cavidades. Restaurações mais amplas resultaram em menores níveis de tensão na restauração e na interface, mas em maiores níveis na estrutura dentária. As cavidades de classe I, de forma geral, mostraram uma maior área de tensão na interface dente/restauração quando comparadas às cavidades de classe 
II. De forma geral, verificou-se que a tensão resultante da contração na estrutura dentária aumentou com o aumento do tamanho da cavidade, enquanto que no material restaurador e na interface a tensão diminuiu. As cavidades classe I conservativas apresentaram comparativamente maiores valores de tensão na interface.
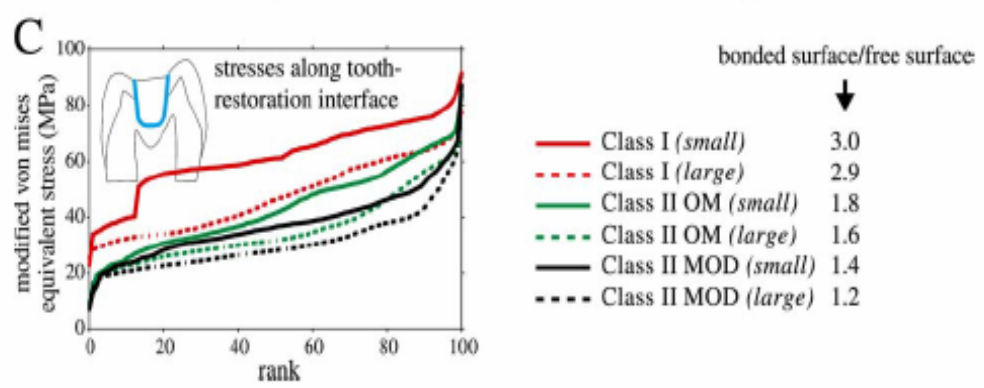
Figura 28 - Comparativo das curvas de tensão resultante de diferentes configurações cavitárias avaliadas $^{184}$

O alto fator de configuração cavitária de cavidades classe I profundas favorece o desenvolvimento de uma maior resultante de forças de contração de polimerização das resinas compostas. Através do teste de microtração, NIKOLAENKO et al. ${ }^{100}$, em 2004, avaliaram a influência do fator $C$ e das diferentes técnicas incrementais de inserção da resina composta na resistência adesiva à dentina (Figura 29), utilizando-se três sistemas adesivos.

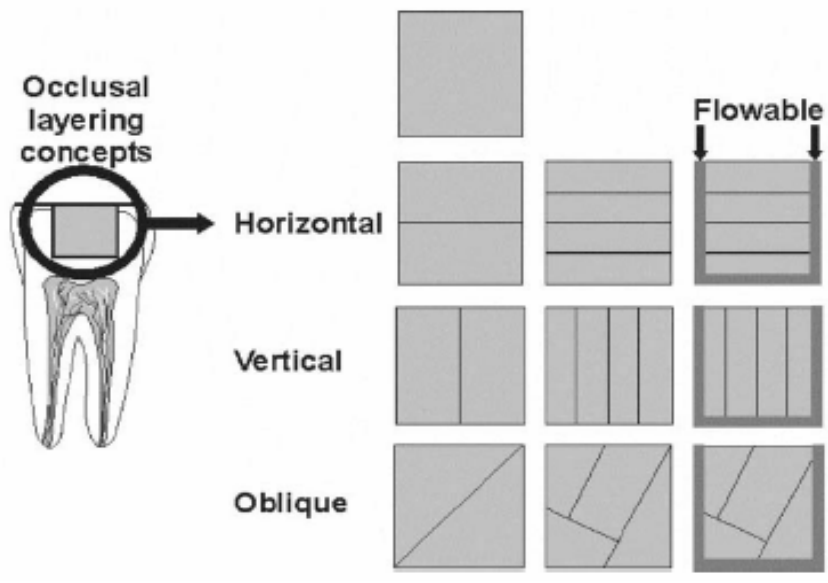

Figura 29 - Diferentes formas de aplicação da resina composta utilizada no estudo ${ }^{100}$ 
A avaliação da resistência adesiva da resina composta Z250 aderida ao Optibond FL (OP), Single Bond (SB) e One Up Bond F (OF) foram realizadas em superfícies dentinárias planas sem a presença de paredes cavitárias e na parede pulpar de cavidades classe I. Na primeira situação, os dentes foram reconstruídos com quatro incrementos de resina composta de $1 \mathrm{~mm}$ de espessura. Já os preparos foram restaurados de 10 diferentes maneiras, cujos incrementos de resina composta foram aplicados horizontalmente, verticalmente e obliquamente, com ou sem aplicação de resina flow em todas as paredes do preparo. Os espécimes foram armazenados em água a $37^{\circ} \mathrm{C}$ por 24 horas e submetidos ao teste de microtração. Segundo os resultados, os valores de resistência adesiva nas superfícies planas foram significantemente maiores comparados aos valores encontrados nos preparos cavitários. Dentro dos grupos com cavidades, não houve diferença significante entre OP e SB, no entanto, os resultados foram superiores aos encontrados com o OF. Dentro dos grupos de cada sistema adesivo, foram detectadas diferenças entre as diferentes formas de inserção das camadas de resina composta. A inserção em um único incremento resultou em baixa adesão na parede pulpar do preparo, sendo que SB e OF apresentaram resultados superiores. Camadas horizontais resultaram em valores de resistência adesiva significantemente maiores que as camadas verticais ou oblíquas. Na Figura 30 observam-se os resultados da aplicação do sistema adesivo Single Bond (SB), sendo que quando a resina foi aplicada em incremento único, os menores valores de resistência adesiva foram observados.

\begin{tabular}{|c|c|c|c|c|c|c|c|c|c|c|}
\hline & \multicolumn{10}{|c|}{$\mu \cdot T B S$ to floors of Class I cavities (MPa) (SD) } \\
\hline & \multirow[t]{2}{*}{ Bulk } & \multicolumn{3}{|c|}{ Horizontal layers } & \multicolumn{3}{|c|}{ Vertical layers } & \multicolumn{3}{|c|}{ Oblique layers } \\
\hline & & 2 & 4 & $4^{3}$ & 2 & 4 & $4^{3}$ & 2 & 4 & $4^{3}$ \\
\hline SB & $\begin{array}{c}8.7^{*} \\
(10.9)\end{array}$ & $\begin{array}{l}12.7 t^{\text {the }} \\
(13.5)\end{array}$ & $\begin{array}{l}29.9^{A} \\
(8.1)\end{array}$ & $\begin{array}{l}30.5^{A} \\
(10.2)\end{array}$ & $\begin{array}{c}8.6^{6} \\
(12.3)\end{array}$ & $\begin{array}{c}9.8^{6} \\
(14.0)\end{array}$ & $\begin{array}{l}18.8^{\mathrm{B}} \\
(8.0)\end{array}$ & $\begin{array}{l}10.7 t^{7 t .} \\
(12.7)\end{array}$ & $\begin{array}{l}15.6^{\natural} \\
(15.9)\end{array}$ & $\begin{array}{l}19.5^{8} \\
(10.0)\end{array}$ \\
\hline
\end{tabular}

Figura 30 - Valores de resistência adesiva Single Bond $x$ forma de aplicação da resina composta $^{100}$

A aplicação da resina flow não propiciou melhor resistência adesiva para o OP. Para os demais adesivos, a utilização da resina flow resultou em melhores 
valores de adesão quando camadas verticais e oblíquas foram realizadas, enquanto que para os incrementos horizontais nenhum efeito foi evidente. De forma geral, o SB e OP mostraram melhores valores de adesão que o OF (adesivo self-etching). Os autores concluíram que o fator $C$ é um fator de influência em termos de adesão dentinária. Em cavidades classe I profundas, a aplicação da resina em camadas horizontais é uma forma de se obter boa adesão à parede pulpar. 


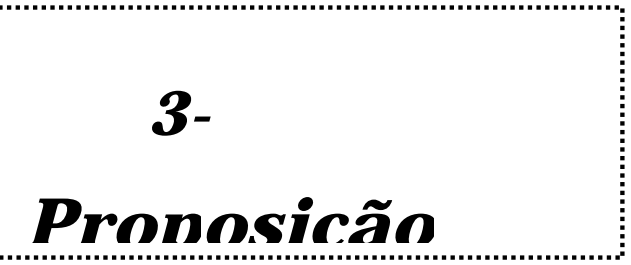




\section{3-Proposição}

Essa pesquisa tem o objetivo de avaliar, in vitro, a resistência de união e a micromorfologia da interface de restaurações adesivas de resina composta, em preparos cavitários de classe I, empregando-se diferentes combinações de fontes de luz fotoativadora. Propõe, ainda, avaliar a cinética da conversão de monômeros resinosos nos materiais restauradores polimerizados com os mesmos aparelhos fotoativadores.

As hipóteses nulas a serem testadas nos diferentes grupos experimentais quando se polimerizam os materiais restauradores com diferentes fontes de luz são:

1. Não há diferença entre os parâmetros de cinética de conversão no sistema adesivo;

2. Não há diferença entre os parâmetros de cinética de conversão na resina composta (base);

3. Não há diferença na espessura da camada de adesivo resultante;

4. Não há diferença na qualidade e espessura da camada híbrida formada;

5. Não há diferença na qualidade e habilidade de selamento dos tags de resina;

6. Não há diferença no padrão de micropermeabilidade;

7. Não há diferença na extensão e localização de fendas formadas;

8. Não há diferença na resistência de união adesiva;

9. Não há diferença quando se compararam combinações de mesma fonte de luz (QTH/QTH, LED/LED e PAC/PAC) 


\section{4- Material e}

Mótodnc 


\section{4- Material e Métodos}

A metodologia descrita, a seguir, divide-se em três partes e baseia-se na utilização de diferentes fontes de luz fotoativadora para polimerizar tanto o sistema adesivo quanto a resina composta. A primeira delas compreende a avaliação da cinética da conversão de monômeros em polímeros. A segunda parte compreende a avaliação da interface adesiva formada na parede pulpar de restaurações adesivas de classe I empregando-se microscopia de fluorescência. Finalmente analisou-se, da resistência de união adesiva nos mesmos grupos experimentais.

\section{1- Materiais restauradores utilizados}

Nas três etapas da metodologia aplicada foram utilizados tanto o sistema adesivo convencional de dois passos, Adper Single Bond, como a resina composta micro-híbrida, Filtek Z250. Ambos são produzidos pelo fabricante 3M ESPE Produtos Odontológicos $\mathrm{Ltda}^{\mathrm{a}}$ que forneceu os produtos para que se realizasse o presente estudo. Estes materiais restauradores foram selecionados por serem de mesmo fabricante, possibilitando compatibilidade entre sistema adesivo e resina composta. Na Tabela 1 são apresentadas as características básicas dos materiais utilizados. Os materiais restauradores são ainda apresentados na Figura 31 (de A a D). Foram obtidos materiais de mesmo número de lote em quantidade suficiente para que fossem utilizados nas diferentes fases da pesquisa.

\footnotetext{
a3M ESPE Dental Products, St Paul, Minnesota, Estados Unidos
} 
Tabela 1 - Características dos materiais restauradores utilizados

\begin{tabular}{|c|c|c|}
\hline $\begin{array}{c}\text { Material } \\
\text { Restaurador }\end{array}$ & Adper Single Bond & Filtek Z250 \\
\hline Características & $\begin{array}{l}\text { Sistema adesivo dental } \\
\text { de frasco único, } \\
\text { fotopolimerizável, à base } \\
\text { de HEMA, BisGMA, } \\
\text { dimetacrilatos, } \\
\text { canforoquinona; } \\
\text { solventes: água e etanol; } \\
\text { copolímeros dos ácidos } \\
\text { poliacrílico e itacônico; } \\
\text { Lote número 4JR }\end{array}$ & $\begin{array}{c}\text { Resina composta direta, } \\
\text { micro-híbrida, } \\
\text { fotopolimerizável, a base de } \\
\text { TEGDMA, UDMA, Bis-EMA, } \\
\text { canforoquinona; } \\
\text { em forma de "compules" de } 2 \\
\text { gramas; cor A2; } 60 \% \text { carga } \\
\text { inorgânica em volume, de } \\
\text { sílica e zircônia; } \\
\text { Lote número 4AU }\end{array}$ \\
\hline
\end{tabular}
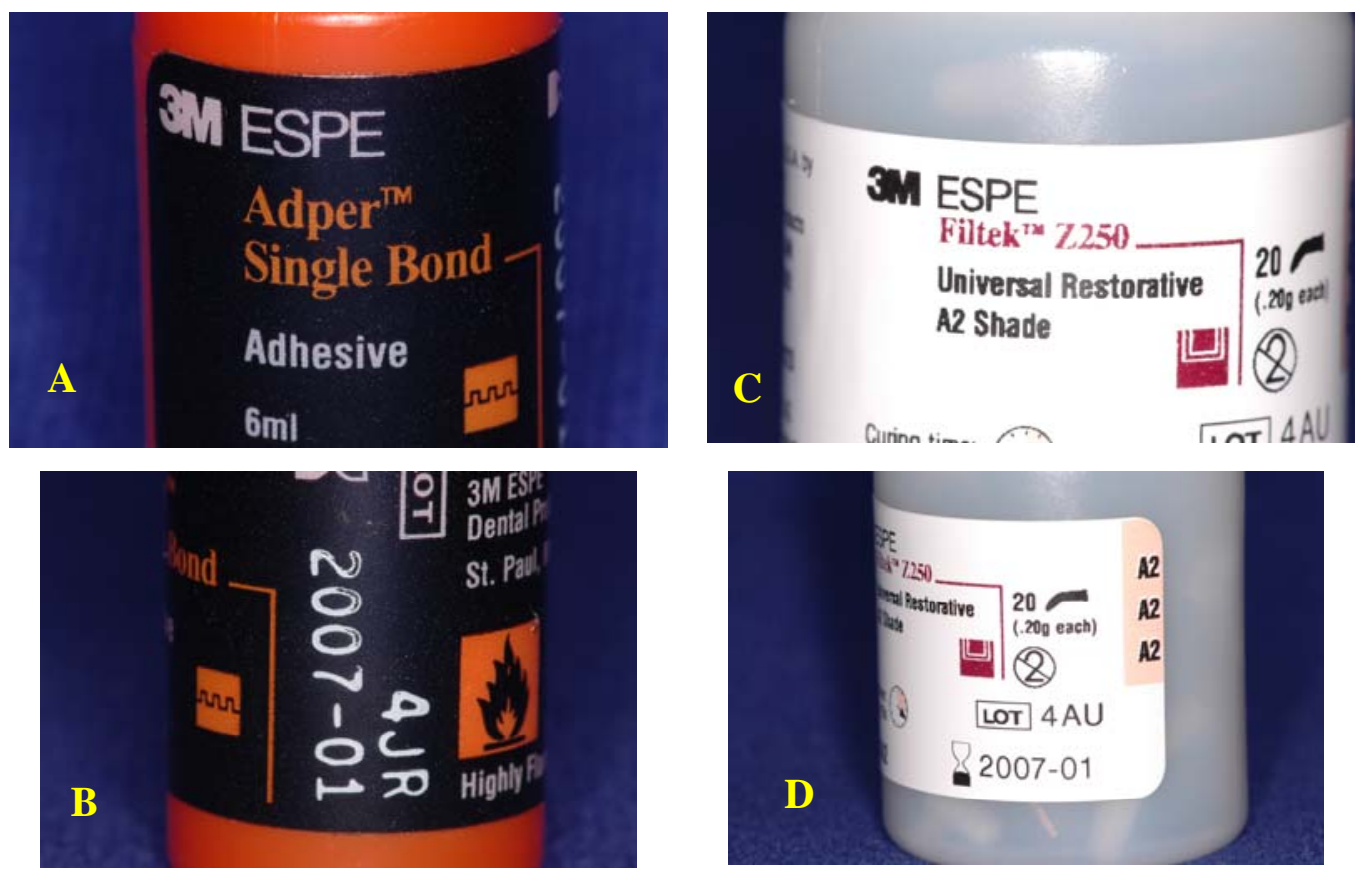

Figura 31 - Sistema adesivo Adper Single Figura 32 - Resina composta Filtek Z250 Bond (A); número de lote no (C); em destaque o número de destaque $(B)$ lote (D) 
4.2- Aparelhos de luz fotoativadora utilizados

Em todas as etapas da metodologia citada foram utilizadas diferentes fontes de luz para polimerizar ambos o sistema adesivo e a resina composta. As características dos aparelhos utilizados no presente estudo estão descritas na Tabela 2.

Tabela 2 - Aparelhos de luz fotoativadora utilizados no estudo

\begin{tabular}{|c|c|c|c|c|}
\hline $\begin{array}{l}\text { Tipo de Luz } \\
\text { Fotoativadora }\end{array}$ & $\begin{array}{c}\text { Marca } \\
\text { Comercial }\end{array}$ & Fabricante & $\begin{array}{l}\text { Densidade } \\
\text { de potência } \\
\left(\mathrm{mW} / \mathrm{cm}^{2}\right)\end{array}$ & $\begin{array}{c}\text { Diâmetro } \\
\text { da ponta } \\
\text { ativa } \\
(\mathrm{mm})\end{array}$ \\
\hline $\begin{array}{c}\text { Halógena } \\
(Q T H)\end{array}$ & XL 3000 & $3 M$ ESPE $^{b}$ & 540 & 6,8 \\
\hline $\begin{array}{l}\text { Diodo Emissor } \\
\text { de Luz (LED) }\end{array}$ & $\begin{array}{c}\text { FREELIGHT } \\
\text { ELIPAR } 2\end{array}$ & 3M ESPE & 750 & 7,3 \\
\hline $\begin{array}{c}\text { Arco de Plasma } \\
\text { (PAC) }\end{array}$ & ARC II M & $\begin{array}{c}\text { AIR } \\
\text { TECHNIQUES }^{c}\end{array}$ & 2.130 & 6,8 \\
\hline
\end{tabular}

Os diferentes aparelhos utilizados possuem características próprias de intensidade de luz (densidade de potência), do tipo de lâmpada ou dispositivo para emissão de luz, e ainda de espectro de irradiância. Na Figura 33 observam-se os espectros de irradiância dos diferentes aparelhos utilizados no presente estudo. $O$ espectro de irradiância e a densidade de potência dos aparelhos de luz utilizados no

\footnotetext{
${ }^{\text {b } 3 M}$ ESPE Dental Products, St. Paul, MN, Estados Unidos

${ }^{c}$ Air Techniques, Inc., Hicksville, NY, Estados Unidos
} 
presente estudo foram mensurados com o auxílio de um radiômetro ${ }^{d}$. A densidade de potência final dos aparelhos foi obtida dividindo-se a área do espectro de irradiância obtido (potência em $\mathrm{mW}$ ) pela área da ponta ativa dos aparelhos fotoativadores (em centímetros quadrados).

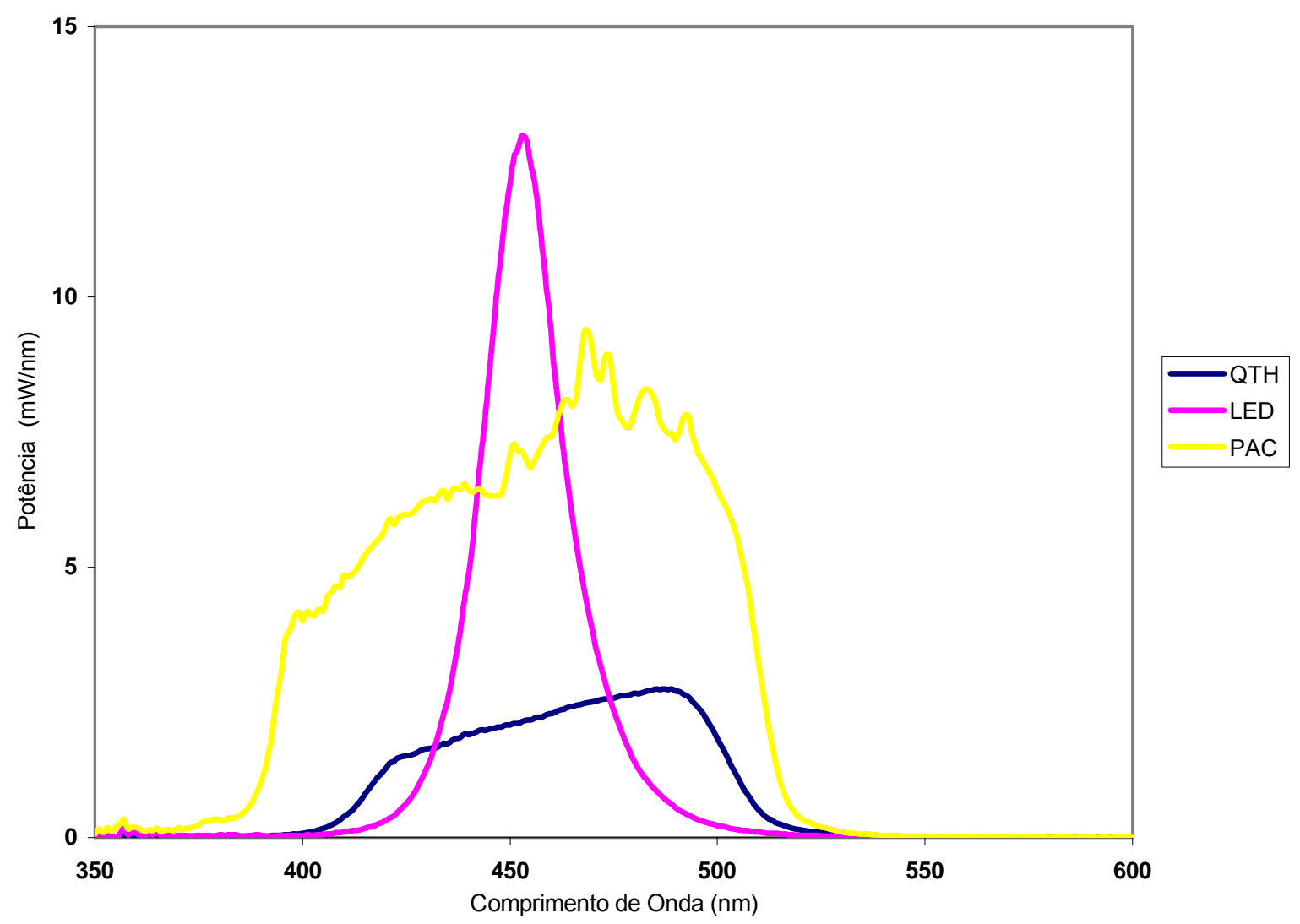

Figura 33 - Espectro de irradiância dos aparelhos fotoativadores utilizados

Ambos os aparelhos QTH e LED foram produzidos pelo mesmo fabricante do sistema adesivo restaurador adesivo, utilizado nessa pesquisa (3M ESPE). Como forma ainda de comparação, utilizou-se de um aparelho de luz de arco de plasma (PAC). Este tipo de aparelho se caracteriza por possuir uma lâmpada na qual o bulbo contém dois eletrodos de tungstênio entre os quais é criada uma alta energia potencial. Esta energia é direcionada para produzir um gás condutor (xenônio), transforma a energia em emissão de luz. Este aparelho possui uma grande densidade de potência, comparado aos demais tipos de aparelho. A emissão de luz

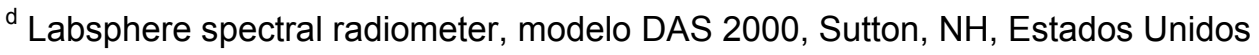


neste tipo de aparelho envolve um amplo espectro, inclusive na região de ultravioleta e de infravermelho. Assim, filtros especiais são aplicados para que estes comprimentos de onda sejam eliminados, evitando-se riscos aos profissionais e aos pacientes. A 3M ESPE não fabrica este tipo de aparelho, e por isso, um aparelho PAC de outro fabricante foi utilizado. O aparelho selecionado para o presente estudo é fabricado pela Air Techniques sendo escolhido pelo espectro de irradiância e por estar ainda sendo comercializado. Na Figura 34 (A, B e C) podem ser vistos os aparelhos de luz fotoativadora de diferentes marcas comerciais utilizados no presente estudo.

O tempo de exposição utilizado com as diferentes fontes de luz foi de acordo com recomendações do fabricante do sistema restaurador empregado: para a resina composta - 20 segundos para QTH e de 10 segundos para LED e PAC; para o sistema adesivo - 10 segundos, independente do aparelho fotoativador utilizado. Os aparelhos foram ainda monitorados constantemente para que a densidade de potência fosse constante durante todo o experimento.

\footnotetext{
e Correspondência eletrônica enviada pela Sra. Mary C. Doruff, 3M ESPE Technical Service, St. Paul,
} MN, Estados Unidos 

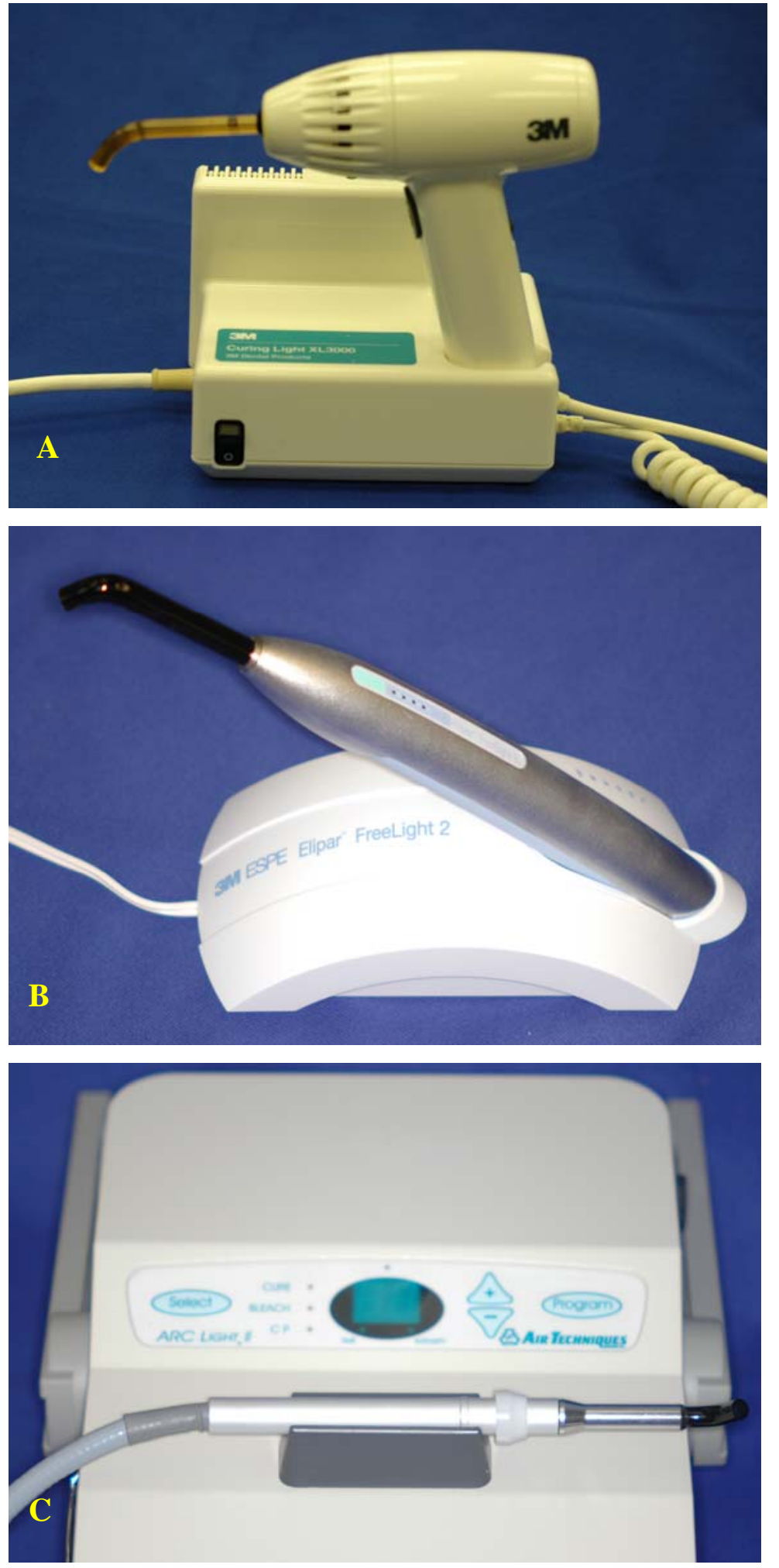

Figura 34 - Aparelhos de luz fotoativadora utilizados no estudo A - QTH; B- LED; C - PAC 


\section{3- Grupos experimentais}

Para a primeira parte do estudo, os diferentes aparelhos com luz fotoativadora foram utilizados para a avaliação da cinética da conversão de monômeros do sistema adesivo, da resina composta (topo e base). Avaliações foram realizadas para cada condição experimental, sendo que somente as variações entre fontes de luz foram consideradas.

Tabela 3- Avaliações realizadas na primeira fase da metodologia

\begin{tabular}{c|c}
\hline Fonte de luz & Condição experimental \\
\hline QTH & Sistema Adesivo \\
LED & Resina composta (Base) \\
PAC & \\
\hline
\end{tabular}

Para ambos, microscopia de fluorescência e teste de resistência de união adesiva, foram utilizadas diferentes fontes de luz fotoativadora para polimerizar tanto o sistema adesivo bem como a resina composta. Para estes testes, os diferentes grupos experimentais serão referidos ao longo da descrição da metodologia, e demais sub-itens, como combinações de luz fotoativadora. Assim, ao se fotoativar o sistema adesivo com QTH e a resina composta com LED, será referido como combinação QTH/LED. Desta forma, as diferentes combinações de fontes de luz para fotoativar o sistema restaurador utilizado no presente estudo forneceram 9 grupos experimentais (Tabela 4). 
Tabela 4 - Grupos experimentais

\begin{tabular}{|c|c|}
\hline \multicolumn{1}{|c|}{$\begin{array}{c}\text { SISTEMA } \\
\text { ADESIVO }\end{array}$} & $\begin{array}{c}\text { RESINA } \\
\text { COMPOSTA }\end{array}$ \\
\hline QTH & QTH \\
\hline QTH & LED \\
\hline QTH & PAC \\
\hline LED & LED \\
\hline LED & QTH \\
\hline LED & PAC \\
\hline PAC & PAC \\
\hline PAC & QTH \\
\hline PAC & LED \\
\hline
\end{tabular}




\section{4- Avaliação da Cinética da Conversão de Monômeros}

A avaliação da cinética de conversões dos materiais estudados foi realizada em espectrofotômetro de raios infravermelhos $(F T-I R)^{f}$. Este aparelho possui um elemento de refletância total atenuada $(A T R)^{g}$, que corresponde a uma "mesa" acoplada ao espectrofotômetro, o qual contém um cristal localizado no centro da mesma que funciona como substrato ativo para raios infravermelhos (Figura $35 \mathrm{~A} \mathrm{e}$ B). O FT-IR emite a radiação infravermelha, que é guiada em direção a um interferômetro, onde interagem com um espelho fixo e um espelho móvel. Os feixes de radiação infravermelhos são então direcionados aos espécimes a serem analisados no ATR. A radiação é, então, forçada em direção ao material experimental que é colocado sobre o cristal. A radiação resultante volta para o espectrofotômetro, e é lida por um detector.
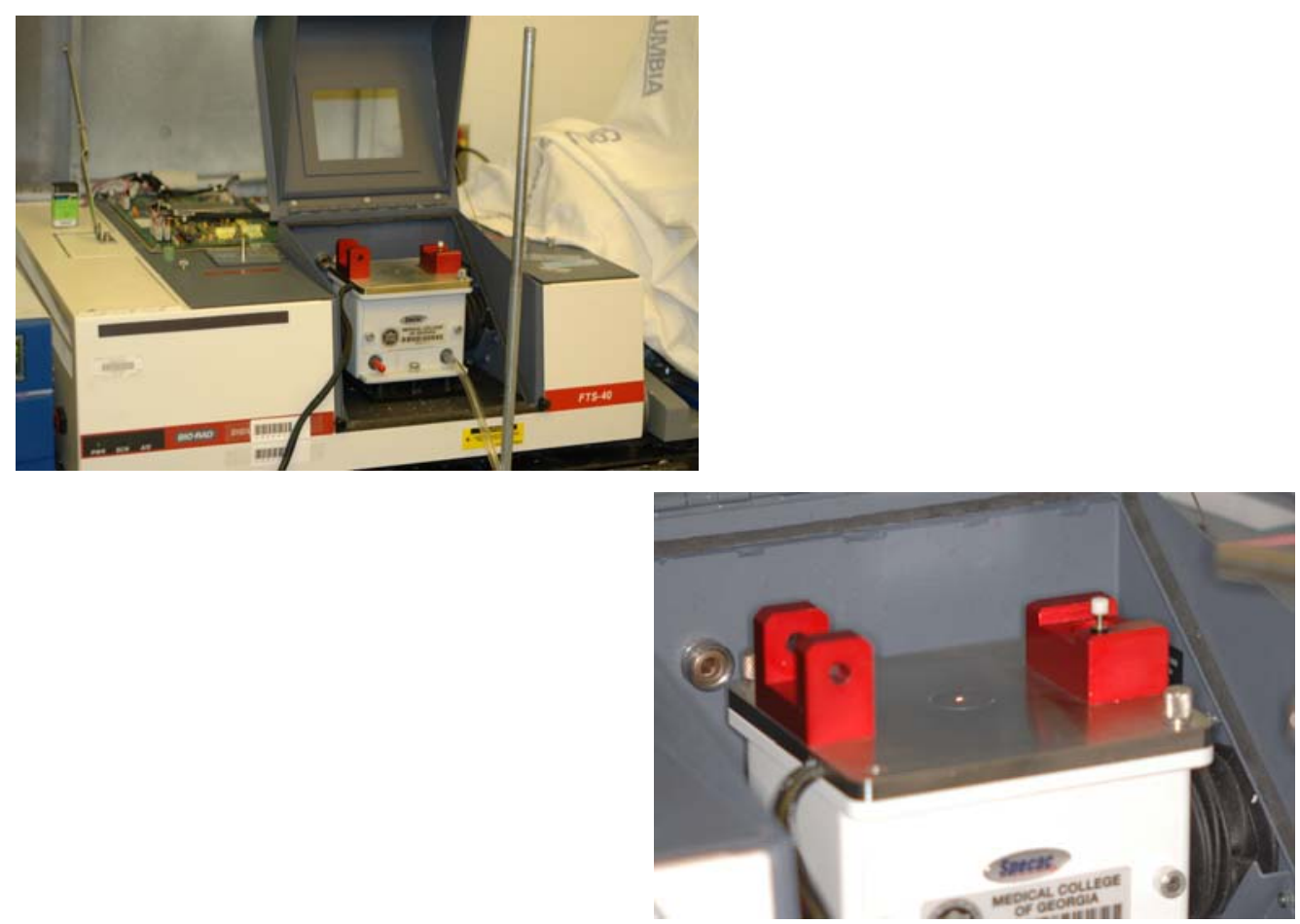

Figura 35 - A: Aparelho espectrofotômetro de raios infravermelhos (FT-IR)

B: Detalhe da mesa ATR

\footnotetext{
${ }^{f}$ FTS-40, Fourier Transform Infrared spectrometer, BioRad Digilab, Cambridge, MA, Estados Unidos ${ }^{g}$ Golden Gate diamond Atenuated Total Reflectance Element MkII, SPECAC Inc., Smyrna, GA, Estados Unidos
} 
Os materiais restauradores foram aplicados sobre este cristal, de acordo com as especificações do fabricante e, então, a luz fotoativadora era ligada. Parâmetros pré-estabelecidos foram utilizados para as análises da cinética de conversão de monômeros no espectrofotômetro ${ }^{141}$. Basicamente, estes métodos monitoram a alteração no pico de absorbância de duplas ligações de moléculas de carbono da cadeia alifática em tempo real. A relação entre a proporção entre o pico de absorção da cadeia alifática a $1.636 \mathrm{~cm}^{-1}$ com respeito ao pico de absorção das duplas ligações de carbono nas cadeias aromáticas a $1.608 \mathrm{~cm}^{-1}$ nos estados polimerizados e não polimerizados foram utilizados para o cálculo do grau de conversão de cada espécime. Os resultados foram expressos como porcentagem de duplas ligações alifáticas remanescentes após o tempo de polimerização em relação às duplas ligações disponíveis quando no estado não fotopolimerizado. Foi utilizada uma resolução de $2 \mathrm{~cm}^{-1}$, entre 1.680 e $1.550 \mathrm{~cm}^{-1}$.

O espectrofotômetro era acionado e então, os raios infravermelhos eram emitidos ao cristal que "varriam", a cada segundo, cerca de $30 \mu \mathrm{m}$ da base do material restaurador que era fotopolimerizado. A cinética de conversão foi avaliada durante 305 segundos. Os cincos primeiros segundos da ativação do espectrofotômetro eram descartados (background) e então o aparelho de luz fotoativadora era acionado e mantido ligado de acordo com o tempo de exposição determinado para cada material restaurador e fonte de luz fotoativadora. Na Figura 36 observa-se uma representação esquemática do cristal localizado ao centro do ATR onde incidem os raios infravermelhos sobre o material em análise. Conforme ocorriam quebras de duplas ligações para a formação da(s) cadeia(s) polimérica(s), o pico das cadeias alifáticas ao longo do tempo de 300 segundos de avaliação se reduzia de acordo com a luz fotoativadora utilizada. A Figura 37 (A e B) demonstra a alteração do pico de absorbância das duplas ligações de carbono que ocorreram nas cadeias alifáticas, antes e depois dos 300 segundos de avaliação. Foram realizadas cinco medições para cada condição material restaurador/lâmpada fotoativadora. Inicialmente delimitou-se a área ao redor do cristal, para que se padronizasse a quantidade de adesivo a ser aplicado. Para tanto, utilizou-se uma fita adesiva com espessura de $170 \mu \mathrm{m}$ e com um orifício de $7 \mathrm{~mm}$ de diâmetro ao centro, aplicada sobre a mesa ATR acoplada ao espectrofotômetro. Duas camadas 


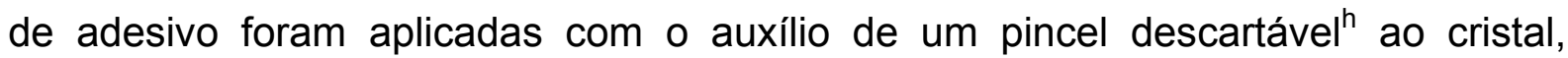
delimitado pela fita adesiva. Em seguida, um jato de ar moderado era aplicado por cerca de 3 segundos para a volatilização dos solventes. Uma tira de poliéster foi aplicada sobre o adesivo e então fotoativado com as diferentes lâmpadas por 10 segundos.

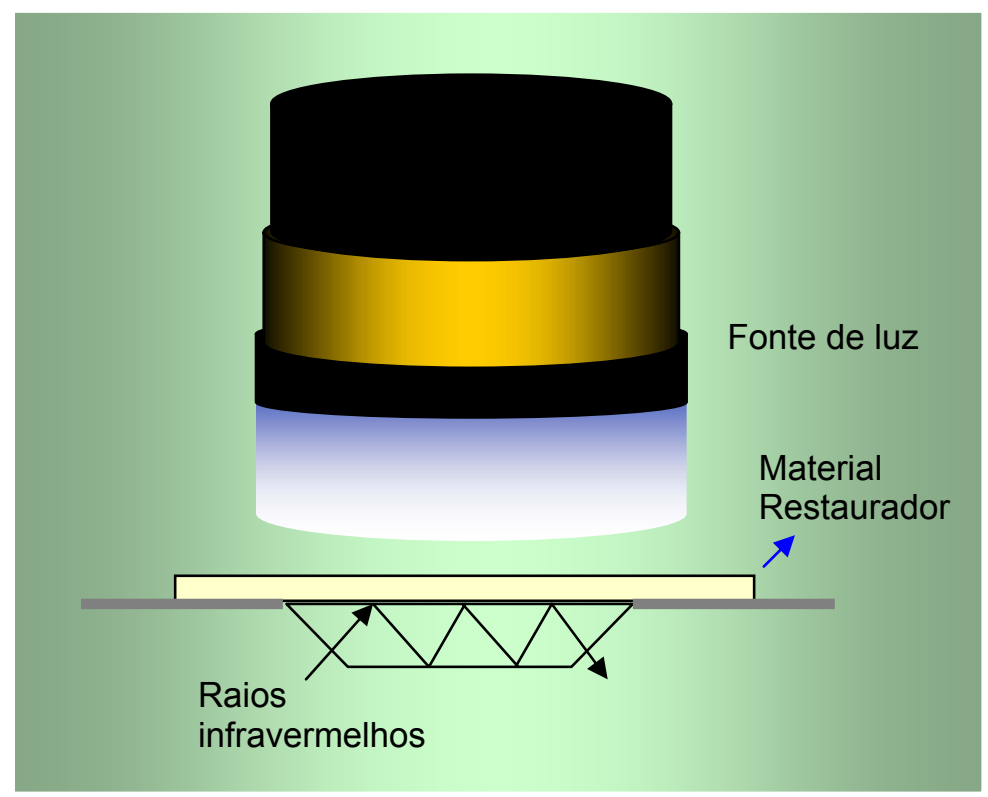

Figura 36 - Representação esquemática dos raios infravermelhos incidentes no cristal localizado no centro do ATR e a reflexão dos mesmos no interior do cristal

Para a resina composta Filtek Z250, utilizou-se um tempo de polimerização de 20 segundos para a QTH e de 10 segundos quando se utilizaram os aparelhos LED e PAC. Foram utilizados anéis cilíndricos de latão com espessura de $2,5 \mathrm{~mm}$ e $5 \mathrm{~mm}$ de diâmetro, nos quais era inserida a resina composta, simulando-se a cinética de conversão na parede pulpar de uma restauração. Segundo o fabricante, o limite para a utilização de incrementos únicos é de $2,5 \mathrm{~mm}$ de espessura. Por esta razão, estabeleceram-se as dimensões do anel para comportar um único incremento de material com esta espessura.

\footnotetext{
${ }^{\mathrm{h}}$ Microbrush Applicators, Grafton, WI, Estados Unidos
} 


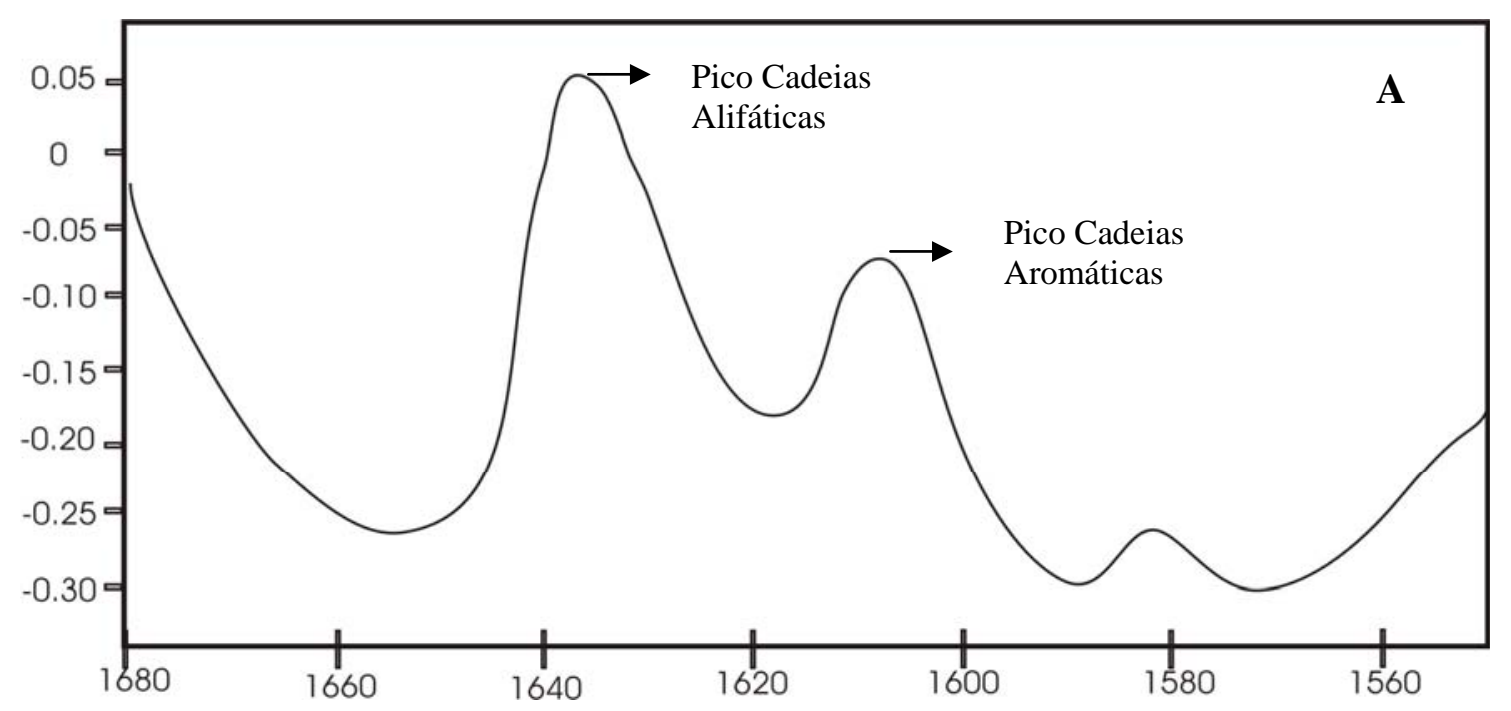

B

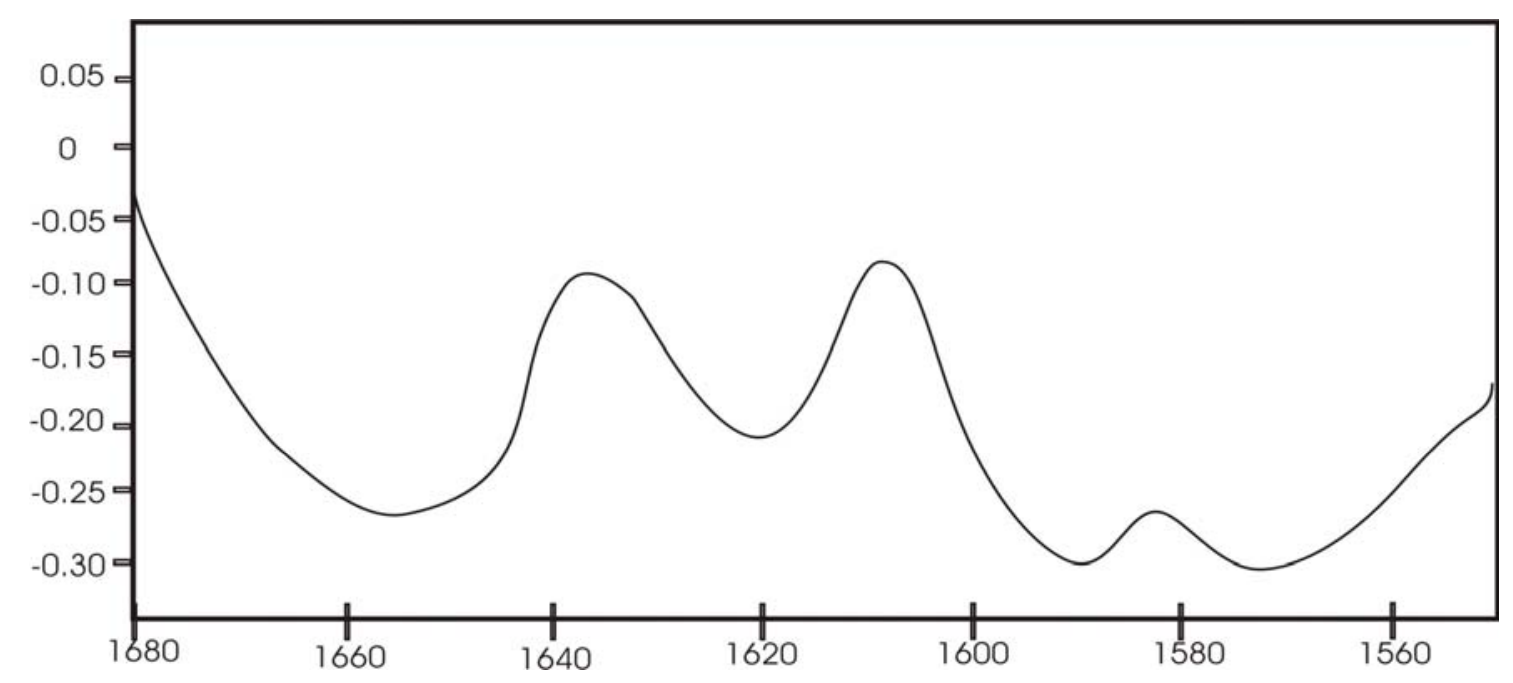

Figura 37 - Curvas de absorção das duplas ligações de carbono nas cadeias alifáticas antes (A) e depois $(B)$ do processo de fotoativação; após 300 segundos, verifica-se a redução no pico de absorção no comprimento de onda de $-1.636 \mathrm{~cm}^{-1}$

Os anéis contendo resina eram posicionados sobre o cristal e as pontas ativas dos aparelhos fotoativadores eram posicionadas a $1 \mathrm{~mm}$ de distância da superfície. Como comparação, simulando a conversão no topo da restauração, foram aplicados pequenos incrementos de resina composta na superfície do cristal no espectrofotômetro. Estes pequenos incrementos eram pressionados com 0 auxílio de um cilindro de aço contra a superfície do cristal, para que uma espessura 
fina de material fosse obtida. Da mesma forma, a ponta ativa dos aparelhos fotopolimerizadores foi mantida a $1 \mathrm{~mm}$ de distância e em ambos os casos fotoativados de acordo com os tempos de exposição acima mencionados. Após o tempo total de análise por espectroscopia, eram realizados cálculos através de um programa de computador.

Os parâmetros da cinética da conversão de monômeros em polímeros analisados foram:

- Conversão total de monômeros em polímeros (\%) ;

- Taxa máxima de conversão (\% / s);

- Tempo em que ocorreu a máxima taxa de conversão (s);

- Conversão de monômeros na máxima taxa (\%);

- Relação conversão na máxima taxa e conversão total (\%).

Os cálculos finais de cada parâmetro foram feitos segundo a segundo até que se atingisse o tempo final de análise. Após a análise da conversão de ambos os materiais fotoativados com as diferentes lâmpadas e tempos de exposição, foram obtidas as médias e desvios-padrão dos cinco corpos de prova para cada condição avaliada e, então, analisados estatisticamente. O teste estatístico utilizado foi o ANOVA a um critério e eventuais diferenças intergrupos analisadas pelo teste de Tukey, a uma significância de $5 \%$. 


\section{5- Procedimentos Restauradores}

Os mesmos prodecimentos restauradores foram realizados tanto para avaliar a micromorfologia da interface adesiva com microscopia de fluorescência como para resistência de união adesiva. Terceiros molares superiores e inferiores recém extraídos foram selecionados para a amostra e mantidos em solução aquosa de timol em uma concentração de 0,1 \% por um período de até três meses. Os dentes foram selecionados de acordo com a aprovação do comitê de ética da Faculdade de Odontologia de Bauru, da Universidade de São Paulo' e do Human Assurance Committee da Faculdade de Odontologia da Medical College of Georgia'. Os dentes foram raspados e polidos e então mantidos em soro fisiológico até que os testes fossem realizados. Os dentes tiveram a superfície oclusal planificada, através do uso de lixa de papel $^{k}$ (granulação 320) montada em uma politriz', utilizando-se, como referência, o sulco intercuspídeo ocluso-vestibular (Figura 37, A e B). À superfície oclusal era então aplicada uma lixa com granulação 600 e, então, de 1.200 para polimento da superfície. Todos os espécimes receberam preparos cavitários de classe I, realizados com brocas do tipo carbide, montadas em turbina de alta rotaçãom.

Os preparos cavitários foram realizados com broca n. ${ }^{\circ} 245^{\mathrm{n}}$ e possuíam as seguintes dimensões: 6,0 mm de extensão; 4,5 mm de largura; 2,5 mm de profundidade (Figura 38, A e B). Essa profundidade correspondia àquela empregada na avaliação com espectrofotômetro de raios infravermelho. O fator "C" era 2,9. A ponta ativa da broca era posicionada em um ângulo de 45 graus com a superfície oclusal. A turbina de alta rotação era acionada e a broca aplicada sobre o esmalte superficial com uma leve pressão. Após a remoção do esmalte superficial, a broca era posicionada na posição vertical e, então, o preparo era realizado cuidadosamente.

\footnotetext{
${ }^{\mathrm{i}}$ Data aprovação: $18 / 10 / 2001$

j HAC file number: 04-03-334/2003, Medical College of Georgia (MCG), Augusta, GA, Estados Unidos

k 320; 600; 1.200 grit SiC, PACE Technologies, Tucson, AZ, Estados Unidos

' Politriz, Modelo DP-10 Struers Inc., Westlake, OH, Estados Unidos

${ }^{\mathrm{m}}$ Kavo, Joinville, Santa Catarina, Brasil

${ }^{n}$ Brasseler Dental Rotary Products, Savannah, GA, Estados Unidos
} 

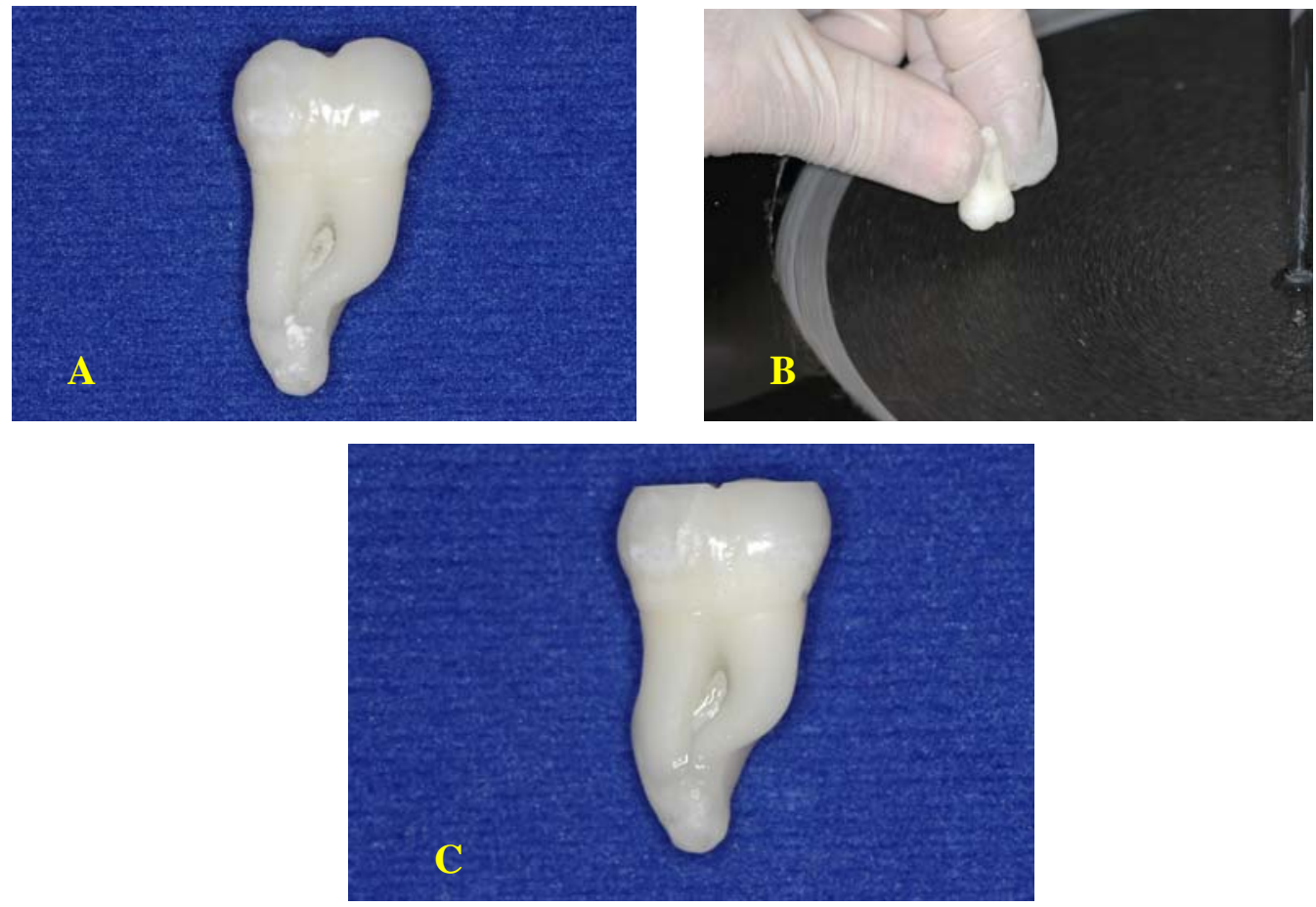

Figura 38 - Terceiro Molar hígido utilizado na amostra (A); redução das cúspides (B) até o sulco intercuspídeo ocluso-vestibular (C)
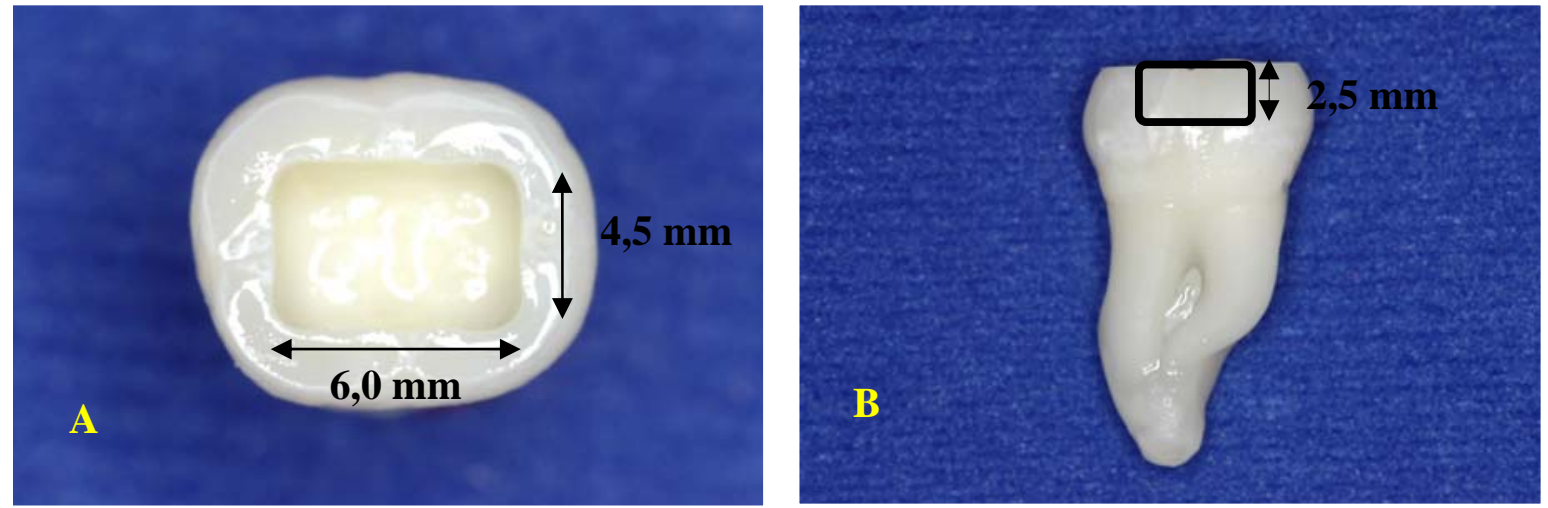

Figura 39 - Dimensões do preparo cavitário, por oclusal (A) e por "vestibular" (B) 
As dimensões dos preparos cavitários foram monitoradas com o auxílio de um paquímetro digital ${ }^{\circ}$. O acabamento dos preparos foi realizado com pontas diamantadas cilíndricas n. ${ }^{\circ} 836-012^{10}$ sendo então lavados com abundante irrigação com água. Todas as margens das cavidades encontravam-se em esmalte dentário. Os ângulos internos da cavidade eram arredondados. Todos os preparos cavitários receberam o sistema restaurador Adper Single Bond e Filtek Z250. Os mesmos materiais restauradores e de mesmo lote acima mencionados foram utilizados.

Para a realização dos procedimentos restauradores, aplicou-se inicialmente ácido fosfórico $^{p}$ na forma de gel, em uma concentração de $35 \%$, em todas as paredes da cavidade por 15 segundos, sendo então lavadas com abundante irrigação com seringa água-ar por pelo menos o mesmo tempo de condicionamento ácido. A superfície interna do preparo foi mantida úmida com o auxílio de papel absorvente, que era inserido no interior do preparo após remoção do agente ácido. O sistema adesivo foi então aplicado seguindo-se as especificações do fabricante. Com o auxílio de um pincel descartável, duas camadas de Adper Single Bond foram aplicadas em todas as paredes da cavidade e então, um jato de ar moderado foi aplicado por cerca de 3 segundos. O adesivo foi fotoativado com um aparelho de luz de acordo com os grupos experimentais estudados. A resina composta Filtek Z250 (cor A2) foi, em seguida, aplicada à cavidade com o auxílio de uma espátula ${ }^{q}$ em camadas e, então, fotoativada somente após o completo preenchimento da cavidade. Inicialmente foi inserida uma camada de cerca de um milímetro sobre a parede pulpar e então mais dois incrementos até que a cavidade fosse totalmente preenchida. O material restaurador foi então fotoativado com a ponta da unidade fotoativadora mantida a $1 \mathrm{~mm}$ de distância, como nos testes com FT-IR. Os dentes foram então armazenados em água destilada por 24 horas para que, então, se realizassem os experimentos.

\footnotetext{
${ }^{\circ}$ Modelo CD-6BS, Mitutoyo, Tókio, Japão

${ }^{\mathrm{p}}$ Scotchbond Etchant, 3M ESPE, St. Paul, MN, Estados Unidos

${ }^{q}$ Mini 3, Hu Friedy Manufacturing Company, Inc., Chicago, IL., Estados Unidos
} 


\section{6- Análise da Micromorfologia da Interface Adesiva}

Os grupos experimentais listados na Tabela 4 foram obtidos para análise da micromorfologia da camada híbrida e das estruturas circunvizinhas. Cinco dentes terceiros molares foram selecionados para cada grupo, totalizando-se uma amostra de 45 dentes. Para que a camada híbrida fosse detectada em microscopia de fluorescência, adicionou-se o corante fluorescente Rodamina $\mathrm{B}^{r}$ ao sistema adesivo Adper Single Bond (Figura 40). Este corante fluoresce na cor vermelho intenso e foi adicionado diretamente ao frasco do adesivo dentinário e mantido em uma máquina agitadoras $^{\text {s }}$ por cerca de 2 horas para a completa dissolução do corante. A adição de $0,16 \mathrm{mg} / \mathrm{ml}$ foi escolhida porque resultados de testes preliminares revelaram que esta concentração não interfere na conversão de monômeros bem como fornece um sinal suficiente em termos de microscopia.

Realizados os preparos cavitários, aplicou-se o sistema adesivo normalmente de acordo com as recomendações do fabricante, como previamente descrito, bem como a aplicação da resina composta na cavidade. Finalizados os procedimentos restauradores (Figura 41), os dentes foram mantidos em água destilada em estufa calibrada a uma temperatura de $37^{\circ} \mathrm{C}$ por 24 horas. Em seguida, os dentes tiveram a(s) raiz(es) removida(s) com o auxílio de um disco diamantado dupla-face fino com refrigeração abundante. A câmara pulpar destes dentes foi então aberta pelo lado radicular com uma broca carbide esférica número $3^{t}$ e o tecido pulpar removido com o auxílio de cureta para dentina e também com um instrumento endodôntico (lima). Após lavagem da câmara pulpar com soro fisiológico, os dentes eram posicionados com a face oclusal voltada para baixo e fixados com o auxílio de cera pegajosa em um reservatório. Os dentes eram, então, imersos em água destilada evitando-se, assim, a desidratação dos mesmos. Para a aplicação do corante, removeu-se parte da água destilada até que o nível estivesse abaixo da margem da câmara pulpar ou da margem radicular remanescente. Com o auxílio de uma pipeta, removia-se a água contida no interior da câmara pulpar, porém sem ressecá-la completamente.

\footnotetext{
${ }^{r}$ Rhodamine B, R6626, batch \#121K3688, Sigma, St. Louis, MO, Estados Unidos

${ }^{s}$ Vortex Machine, Scientific Industries, Inc., New York, NY, Estados Unidos

${ }^{t}$ Brasseler Dental Rotary Products, Savannah, GA, Estados Unidos
} 
Uma solução aquosa contendo o corante fluorescente verde Fluoresceína", em uma concentração de $0,1 \%$, foi aplicado na câmara pulpar (Figura 42) com o auxílio de uma pipeta. A utilização do corante fluorescente Fluoresceína conjugado a um polissacarídeo (Dextran) permitia a obtenção de uma solução aquosa mais homogênea e desta forma fornecer resultados mais confiáveis. O peso molecular nominal da Fluoresceína conjugada era 10.000 (real $=3.000$ ). Os dentes foram mantidos no reservatório por pelo menos 4 horas $^{62}$ para que a solução contendo o corante fluorescente verde atingisse a interface adesiva. Após este período, os dentes foram lavados em água corrente durante um minuto e então secos com papel absorvente. Os dentes foram incluídos em resina epóxicav e mantidos livres de movimentação até que houvesse a completa polimerização da resina.

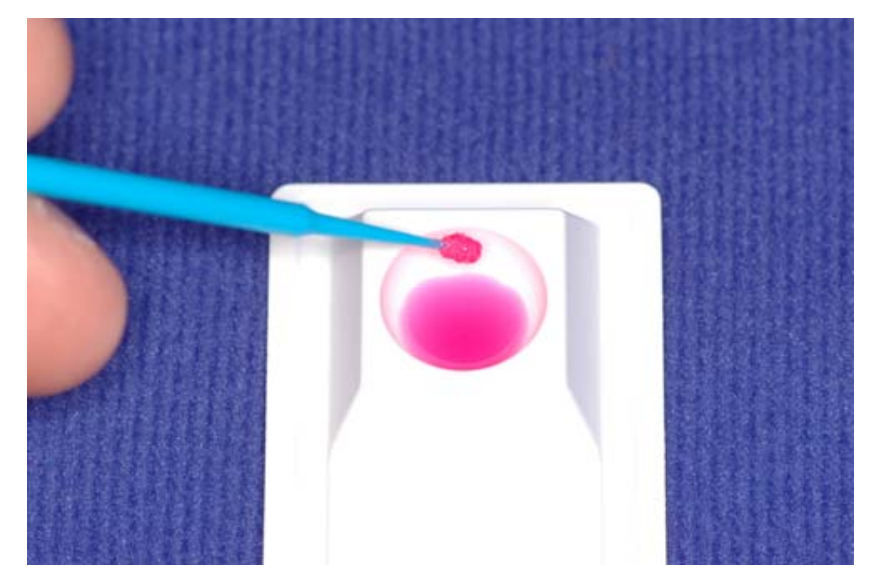

Figura 40 - Sistema adesivo com adição de corante fluorescente Rodamina B; o corante fluoresce quando excitado no comprimento de onda adequado, destaca a distribuição do sistema adesivo na dentina desmineralizada

\footnotetext{
${ }^{\text {u }}$ Fluorescein-Isothiocyanate-Dextran, FD10, batch \#123K0723, Sigma, St. Louis, MO, Estados Unidos

${ }^{\vee}$ Castin'Craft Clear Liquid Plastic, Environmental Technology Inc., Fields Landing, CA, Estados Unidos
} 


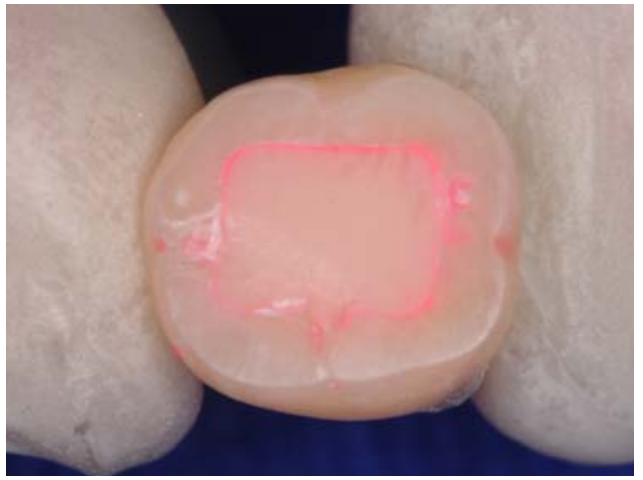

Figura 41 - Aspecto final dos dentes restaurados após a adição de corante fluorescente vermelho ao sistema adesivo estudado
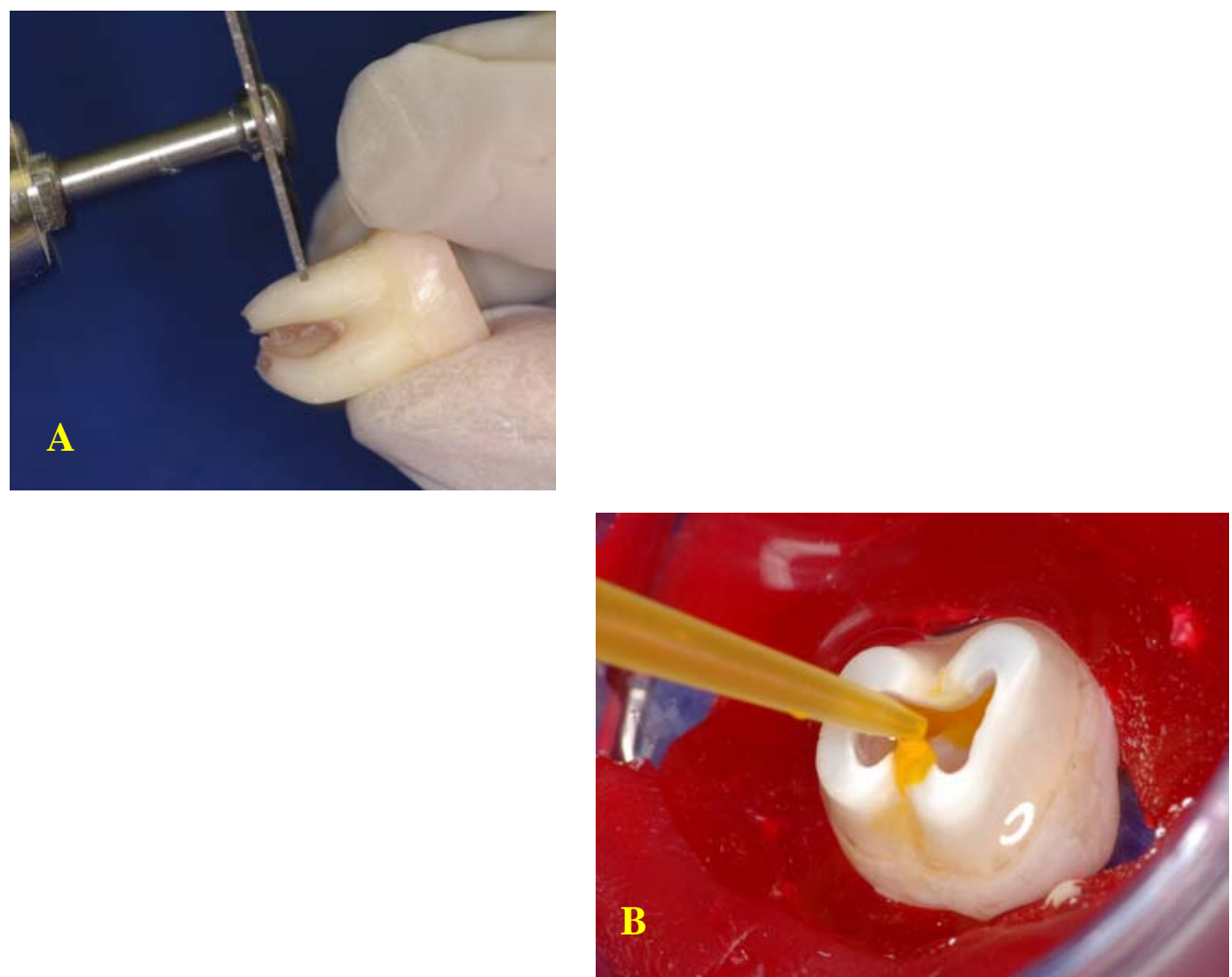

Figura 42 - Aplicação do corante fluorescente Fluoresceína à câmara pulpar (B), depois do seccionamento $(A)$ e correto posicionamento do espécime 
Os dentes incluídos em resina epóxica foram, então, seccionados no sentido vestíbulo-lingual (palatino), com um disco de diamantes, em uma máquina de corte ${ }^{\mathrm{w}}$ refrigerada com óleo vegetal ${ }^{\mathrm{x}}$. Selecionou-se esta forma de refrigeração porque testes preliminares mostraram que a Fluoresceína é insolúvel em óleo vegetal. Além disso, a utilização de água destilada poderia promover a disseminação deste corante em outras áreas durante o processo de seccionamento, o que resultaria em resultados falso-positivos. Foram obtidas secções de cerca de $0,5 \mathrm{~mm}$ de espessura. Duas secções foram aleatoriamente selecionadas e então afixadas em lâminas de vidro para microscopia ${ }^{y}$ com uma gota de "cola" a base de resina acrílica de baixa viscosidade $^{z}$, que permite uma visualização dos mesmos sem que houvesse alteração no espécime e no comprimento de onda excitador dos corantes utilizados (Figura 43, A e B).

As secções montadas em lâmina foram mantidas protegidas da luz ambiente e da desidratação em um reservatório lacrado e escuro. Aplicou-se às secções, ainda, óleo de imersão para microscopia, para que se evitasse a desidratação dos mesmos. Os espécimes foram imediatamente analisados em microscópio de fluorescência com Laser de Dois Fótons ${ }^{\text {aa }}$. Através de testes pilotos realizou-se previamente a calibração do microscópio de fluorescência. Para isso, controles negativos sem a presença de corante foram analisados para que se subtraísse uma possível fluorescência dos tecidos dentários e da resina composta (background). Também foram produzidos controles com somente um dos dois corantes, ou seja, espécimes somente com Rodamina B ou espécimes somente com Fluoresceína. Assim, com o auxílio destes controles, calibrou-se o microscópio a fim de que não houvesse resultados falso-positivos, já que há uma sobreposição das curvas de emissão dos corantes fluorescentes utilizados. As curvas de emissão de fluorescência de ambos corantes fluorescentes estão contidas na Figura 44.

Foram utilizadas lentes objetivas de imersão em água com aumento de até 40x. Sobre as secções afixadas nas lâminas de microscópio foi aplicada uma lamínula de vidro, com uma espessura de $170 \mu \mathrm{m}$. Entre a lente objetiva e a

\footnotetext{
${ }^{\mathrm{w}}$ Isomet, Buehler Ltd., Evanston, Illinois, Estados Unidos

${ }^{x}$ Great Value, Wal-Mart, Bentonville, AR, Estados Unidos

${ }^{y}$ Fisher Scientific, Pittsburgh, PA, Estados Unidos

${ }^{z}$ Cytoseal XYL, Stephens Scientific, Riverdale, NJ, Estados Unidos

${ }^{a a}$ Zeiss LSM 510 Meta Confocal Microscope, Göttingen, Alemanha
} 
lamínula era aplicada água destilada (NA = 1,2). Foi utilizado um laser de TitânioSafira, operado com uma potência de pelo menos $700 \mathrm{~W}$, que emitia um comprimento de onda de excitação de $780 \mathrm{~nm}$, em altíssima freqüência. O pico de emissão de fluorescência foi obtido em espectrofotômetro de fluorescência ${ }^{\text {bb }}$ sendo que o da Rodamina B foi em 585 nm e o da Fluoresceína em 544 nm. Filtros foram utilizados para que se separassem as sobreposições de curva de emissão (overlapping) evitando-se resultados falso-positivos.

Os espécimes foram analisados no microscópio de fluorescência e seguiam um protocolo pré-estabelecido. Ao se iniciar uma nova análise, o mesmo protocolo era reutilizado (Re-use tool). Através de um programa de computador acoplado ao microscópio realizavam-se os processamentos das imagens. Foram utilizados inicialmente filtros pré-estabelecidos e então removida a fluorescência das estruturas dentárias, bem como a fluorescência da resina composta (brightfield). As imagens eram então finalizadas e catalogadas de acordo com o grupo experimental.

Um exemplo de imagem da interface adesiva pode ser vista na Figura 45. Nesta imagem vêem se claramente a camada híbrida e estruturas anexas destacadas em vermelho. Também se vê o corante verde que foi aplicado na câmara pulpar que, através dos túbulos dentinários, se dirigiu à interface. O exemplo exposto nesta figura apresenta uma camada híbrida homogênea e nítida, com uma camada de adesivo evidente (vermelho intenso), com tags de resina uniformes e túbulos dentinários aparentemente selados. As análises quantitativas e qualitativas foram realizadas através de um programa de computador processador de imagens de fluorescência ${ }^{c c}$ que possibilitava a visualização dos diferentes corantes fluorescentes individualmente ou simultaneamente. Somente a parede pulpar dos preparos cavitários foi analisada. Cerca de 10 imagens da parede pulpar de cada secção foi obtida, totalizando cerca de 100 imagens por grupo experimental. Imagens de áreas de ângulo das cavidades foram desprezadas. As imagens de cada área avaliada possuíam $230 \mu \mathrm{m}$ de extensão (fieldwidth) e a camada híbrida era enquadrada na posição horizontal e mediana das mesmas.

\footnotetext{
${ }^{\mathrm{bb}} \mathrm{F} 2500$, Fluorescence Spectrophotometer, Hitachi High-Technologies Corporation, Tókio, Japão

${ }^{c c}$ Zeiss LSM Image Browser, versão 3.2, Göttingen, Alemanha
} 

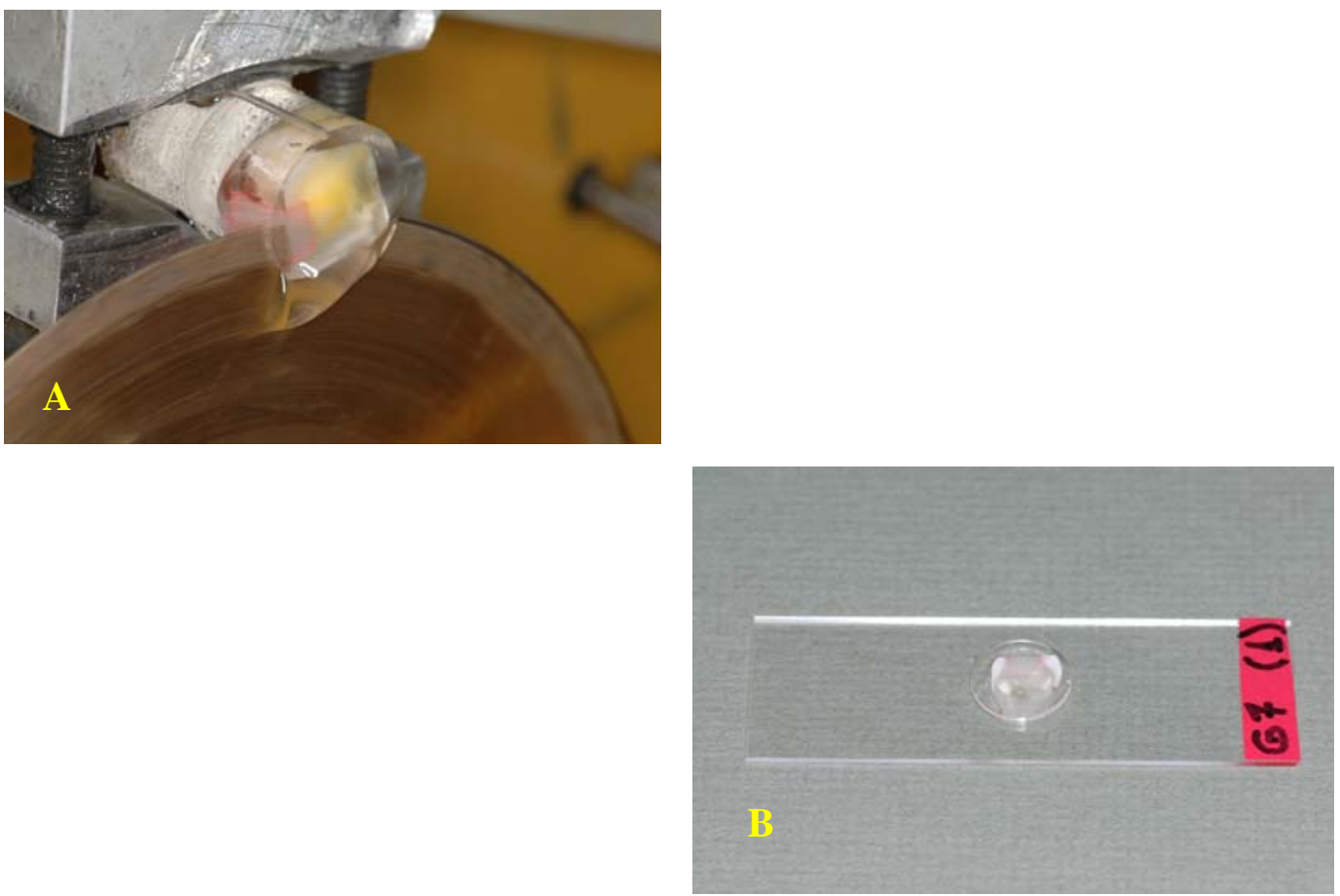

Figura 43 - Seccionamento dos dentes em máquina de corte (A); fixação dos espécimes em lâmina de vidro para microscopia (B)

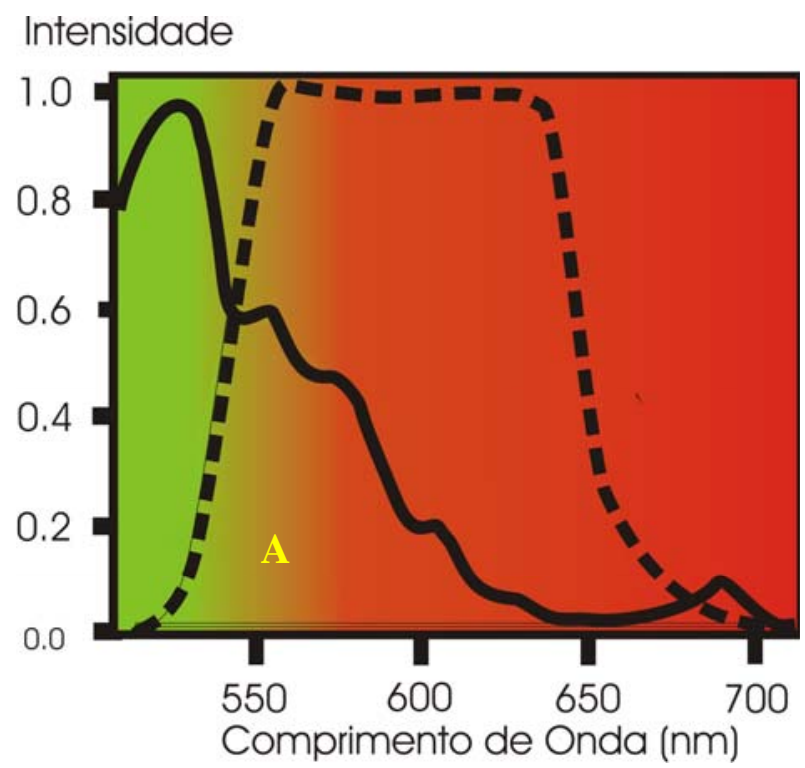

Figura 44 - Sobreposição de curvas de emissão de fluorescência dos corantes Rodamina B (linha tracejada) e Fluoresceína (linha contínua); filtros removiam a área de overlapping ( A ), evitando-se resultados falso-positivos 
Foram obtidas imagens da subsuperfície em todos os espécimes até uma profundidade de pelo menos $10 \mu \mathrm{m}$, em intervalos de $2 \mu \mathrm{m}$ entre cada camada. Padronizou-se uma profundidade de $6 \mu \mathrm{m}$ para as análises da camada híbrida e estruturas adjacentes. Eventuais dúvidas eram resolvidas avaliando-se imagens a 4 $\mu \mathrm{m}$ ou a $8 \mu \mathrm{m}$ de profundidade.

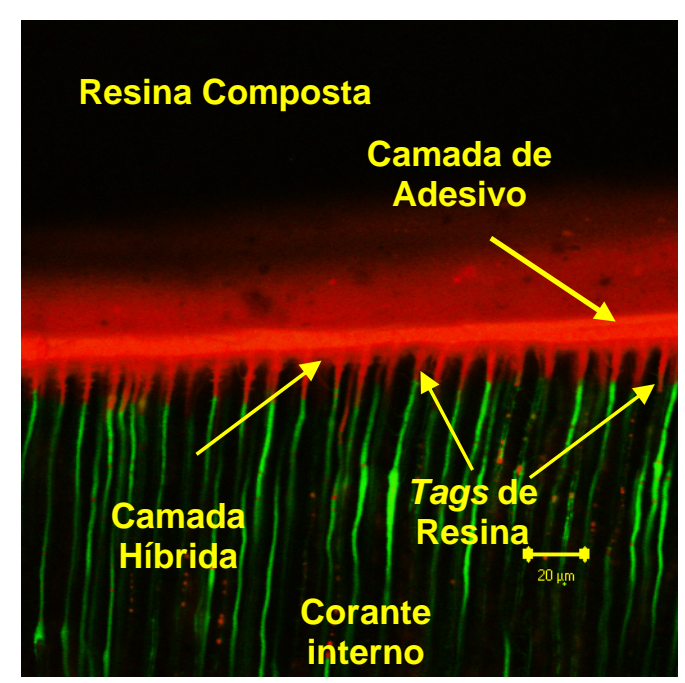

Figura 45 - Fotomicrografia da interface adesiva e estruturas adjacentes

As análises qualitativas e quantitativas realizadas foram:

- Espessura da camada de adesivo;

- Espessura e Qualidade da camada híbrida;

- Teste de Micropermeabilidade

- Habilidade de selamento e qualidade dos tags de resina;

- Localização de fendas e;

- Extensão de fendas. 
A espessura de camada híbrida e de adesivo foi feita em $\mu \mathrm{m}$. Padronizou-se a obtenção das medidas na região central e no terço médio das extremidades das imagens. Os resultados dos diferentes grupos experimentais em relação a estas mensurações foram analisados com o teste estatístico ANOVA, a dois critérios e as possíveis diferenças intergrupos detectadas com teste Tukey, a um nível de significância de $5 \%$.

Os escores para qualidade de camada híbrida foram realizados com a observação somente do corante fluorescente vermelho, que foi adicionado ao sistema adesivo. Assim, os escores ficaram determinados:

- Escore 1 - camada híbrida nítida, bem organizada, possibilidade de mensuração ("alta" qualidade);

- Escore 2 - camada híbrida nítida, parcialmente organizada, possibilidade de mensuração ("média" qualidade);

Escore 3 - camada híbrida desorganizada, sem nitidez, impossível de ser mensurada ("baixa" qualidade).

O padrão de micropermeabilidade foi avaliado de acordo com a penetração da Fluoresceína (corante fluorescente verde) no sentido base da camada híbridaresina composta. Na Figura 46 estão representados esquematicamente os diferentes escores para micropermeabilidade, assim determinados:

- Escore 1 - corante verde até a extremidade dos tags de resina, sem penetração lateral;

- Escore 2 - corante verde penetrando lateralmente o tag de resina, até a base da camada híbrida;

- Escore 3 - corante verde penetrando a camada híbrida, sem atingir a camada de adesivo;

- Escore 4 - corante verde presente entre a camada híbrida e a camada de adesivo ou internamente na camada de adesivo;

- Escore 5 - corante verde ultrapassando a camada de adesivo, presente em resina composta. 


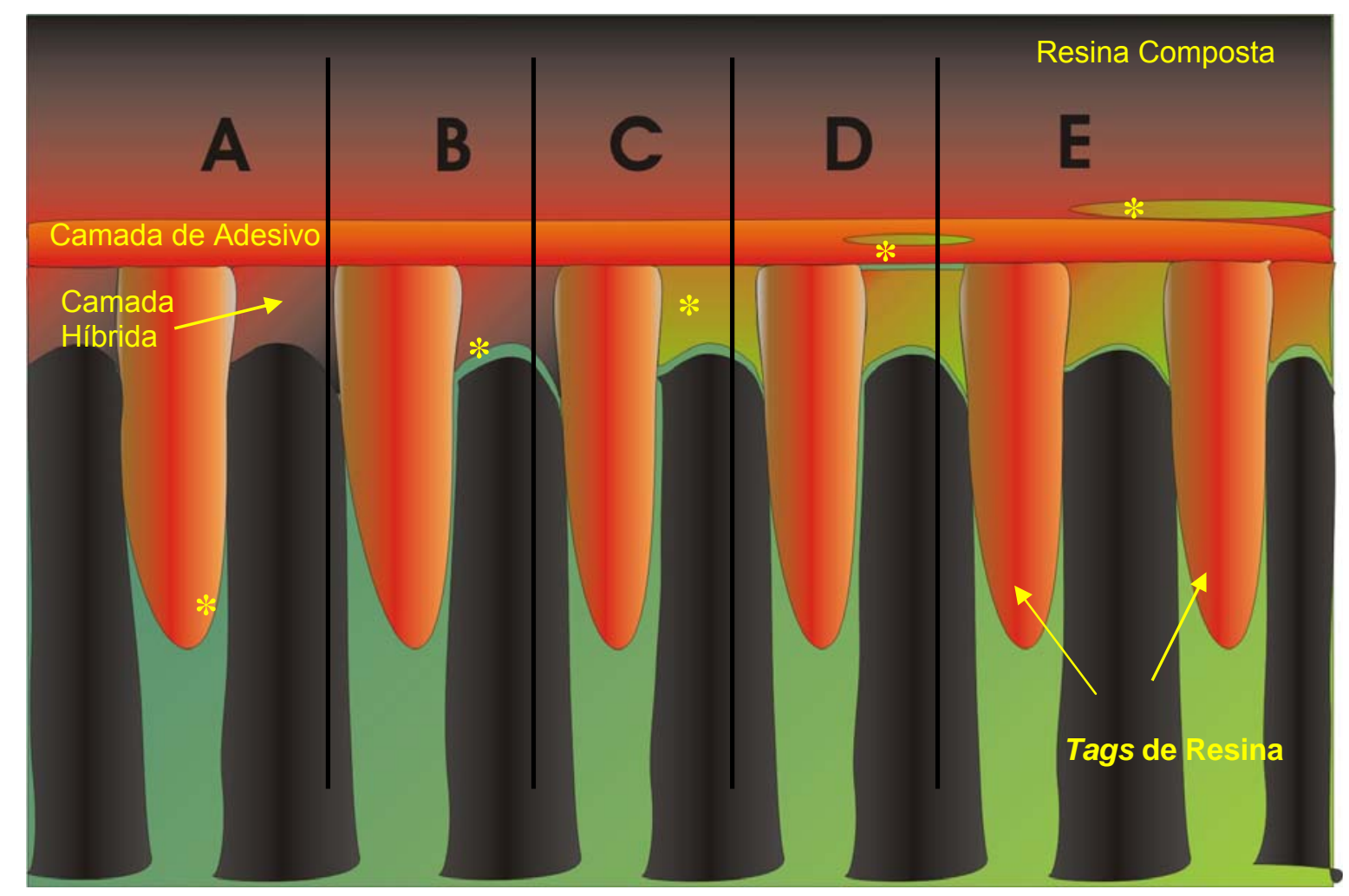

Figura 46 - Representação esquemática da análise da micropermeabilidade $\left({ }^{*}\right)$ : (A) Selamento "perfeito"; (B) Penetração do corante até a base da camada híbrida; (C) Penetração do corante na camada híbrida; (D) Penetração do corante entre a camada híbrida e a camada de adesivo e/ou na camada de adesivo; (E) Penetração do corante entre a camada de adesivo e a resina composta

A avaliação qualitativa da micropermeabilidade era feita atribuindo-se escores a cada $20 \mu \mathrm{m}$ em cada imagem analisada, totalizando-se 10 diferentes áreas. A média final para cada imagem era calculada e então a média por secção obtida. Finalmente eram obtidas médias dos valores médios das duas secções que correspondiam a um espécime (dente).

A qualidade dos tags de resina foi avaliada, sendo que os seguintes escores foram aplicados:

- Escore 1 - Nítidos, bem organizados;

- Escore 2 - Visíveis, parcialmente organizados;

- Escore 3 - Quase que totalmente desorganizados, sem nitidez

A habilidade de selamento dos tags de resina foi analisada atribuindo-se os seguintes escores: 
- Escore 1 - Maioria selados (>2/3)

- Escore 2 - Parcialmente selados

- Escore 3 - Maioria não selados $(<1 / 3)$

Os escores para localização de fendas foram estabelecidos em relação à presença ou não de corante fluorescente verde. Assim, foram considerados escores mais severos quando houvesse a presença deste corante no interior das fendas. A avaliação qualitativa da localização de fendas ficou assim definida:

- Escore 1 - Ausência de fendas;

- Escore 2 - Presença de fenda(s) entre a camada de adesivo e a resina composta, SEM a presença de corante verde;

- Escore 3 - Presença de fenda(s) na camada de adesivo SEM a presença de corante verde;

- Escore 4- Presença de fenda(s) entre a camada híbrida e a de adesivo, SEM a presença de corante verde;

- Escore 5- Presença de fenda(s) entre a camada híbrida e a de adesivo, COM a presença de corante verde;

- Escore 6 - Presença de fenda(s) na camada de adesivo, COM a presença de corante verde;

- Escore 7 - Presença de fenda(s) entre a camada de adesivo e a resina composta, COM a presença de corante verde.

Para a avaliação qualitativa de localização de fendas, padronizou-se determinar somente um escore por imagem. Os escores de presença e localização de fendas foram atribuídos quando os escores 1 e 2 para qualidade de camada híbrida eram aplicados. Quando a camada híbrida recebia o escore 3 para qualidade ("baixa" qualidade), os escores 1, 4 e 5 para presença e localização de fendas não eram atribuídos. As avaliações qualitativas da camada híbrida e dos tags de resina, bem como localização das fendas, foram estatisticamente analisados com o teste Kruskal-Wallis e teste de Dunnet para se detectar possíveis diferenças intergrupos, a um nível de significância de $5 \%$. Quanto à extensão das fendas, após a mensuração da extensão das mesmas, realizava-se a porcentagem em relação à 
extensão total da imagem $(230 \mu \mathrm{m})$. Para a análise dos resultados foi realizado o teste estatístico ANOVA, a dois critérios, além do teste Tukey para diferenças intergrupos, a uma significância de 5 \%. Em todas as avaliações quantitativas e qualitativas dos grupos experimentais também foram considerados os fatores fotoativação do sistema adesivo e fotoativação da resina composta de forma independente. 


\section{7- Resistência de União Adesiva}

Após o período de armazenamento em água destilada por 24 horas a $37^{\circ} \mathrm{C}$, vinte e sete dentes terceiros molares restaurados receberam três camadas de resina composta, cada uma delas com $1 \mathrm{~mm}$ de espessura, sobre a superfície da restauração final. Realizou-se este procedimento a fim de que se obtivessem espécimes com a mesma extensão de material restaurador e de dentina quando da realização do teste de microtração. Para isso, uma lixa de papel (granulação 600) foi aplicada à superfície das restaurações com o intuito de tornar a superfície rugosa. Sobre esta superfície do material restaurador foi, então, aplicado o ácido fosfórico em gel (35 \%) e o sistema adesivo como previamente especificado. Cada incremento de resina composta que foi acrescentado sobre a superfície da restauração foi fotopolimerizado por 20 segundos, utilizando-se QTH. Após a inserção de resina composta sobre as restaurações finais (Figura 47), os dentes foram seccionados em uma máquina de corte ${ }^{\text {dd }}$ refrigerada com água destilada. Os dentes foram seccionados no sentido mésio-distal e então, no sentido vestíbulolingual (ou vestíbulo-palatino) para que se obtivessem "palitos" de cerca de 0,90 $\mathrm{mm}^{2}$. Espécimes que envolviam áreas de ângulos das cavidades, bem como de câmara pulpar foram desprezados. Os "palitos" foram mantidos em água destilada até que fossem avaliados, o mais rápido possível, em uma máquina de testes universal $^{\mathrm{ee}}$. Para o teste de resistência adesiva propriamente dito, os espécimes foram afixados ao dispositivo de Chiucchi (Figura 48), acoplado à máquina de testes, através da utilização de uma cola à base de cianoacrilato ${ }^{\mathrm{ff}}$. Após o aguardo do tempo de reação do ativador com o líquido base da cola aplicada, a máquina era acionada e os espécimes testados na forma de tração, com uma célula de carga de $10 \mathrm{Kg}$, a uma velocidade de $1 \mathrm{~mm} / \mathrm{min}$, até que houvesse o rompimento da união adesiva. Cerca de três dentes foram testados por grupos, sendo que cada um deles produziu por volta de seis "palitos".

\footnotetext{
dd Isomet, Buehler Ltd., Evanston, Illinois, Estados Unidos

ee Chatillon Vitrodyne V1000, Liveco Inc, Burlington, VT, Estados Unidos

ff Zapit, DVA Inc., Corona, CA, Estados Unidos
} 


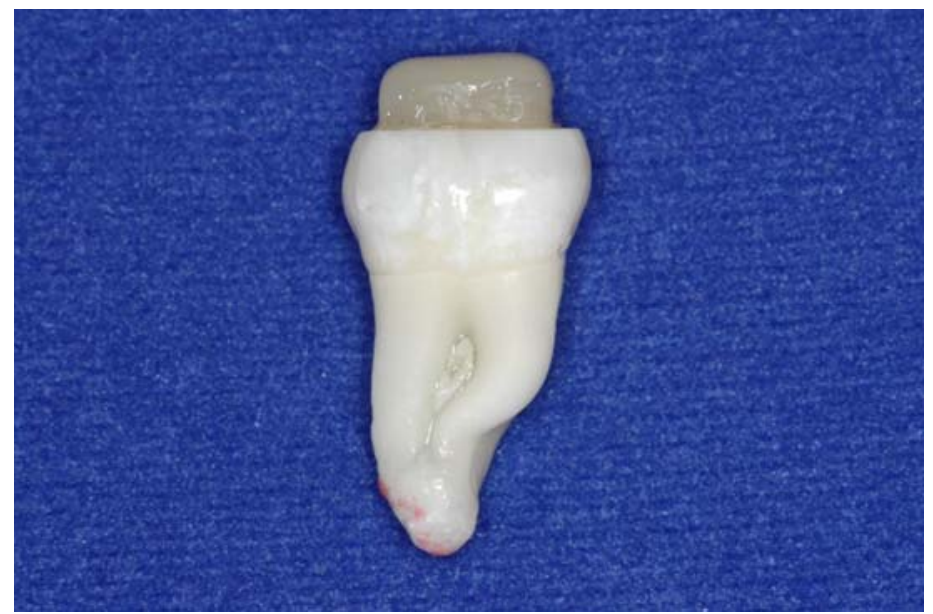

Figura 47 - Aspecto final do dente após adição de resina composta sobre a restauração final para o teste de microtração

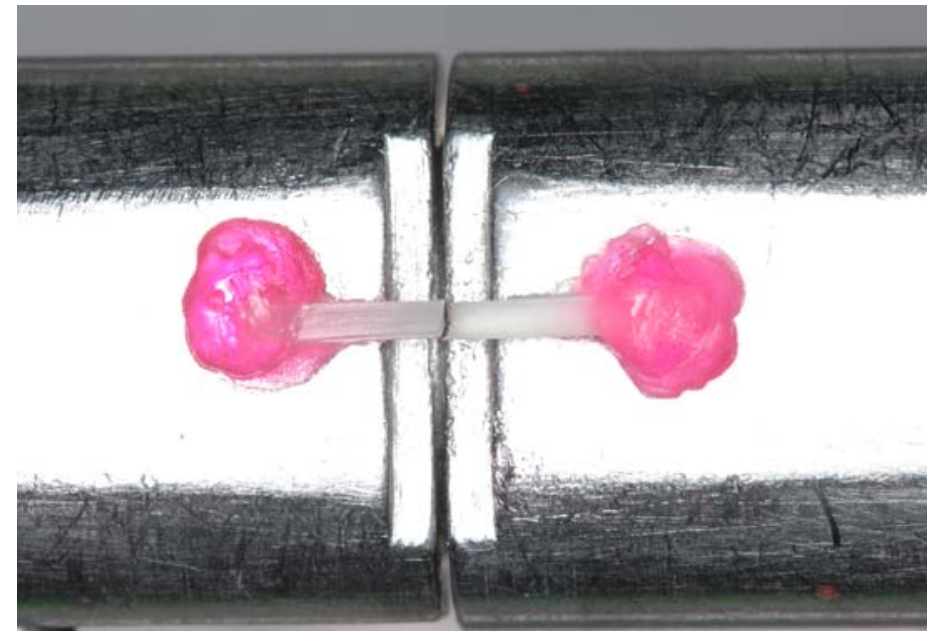

Figura 48 - Espécime colocado no dispositivo para a realização do teste de resistência adesiva; as extremidades são afixadas com cola com a interface adesiva perpendicular à direção da ação das forças de tração 
Através do auxílio de um programa de computador acoplado a máquina de testes, valores de resistência adesiva eram obtidos e calculados de acordo com a seguinte fórmula:

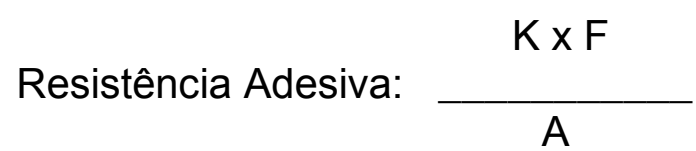

onde $K$ significa carga em quilograma $(\mathrm{kg}), F$ a constante de aceleração da gravidade $\left(\mathrm{g}=9,8 \mathrm{~m} / \mathrm{s}^{2}\right.$ ) e $A$ significa a área aderida em milímetros quadrados. Os valores finais de resistência adesiva eram obtidos em MPa. As médias e desviospadrão de resistência adesiva de cada grupo experimental foram obtidos e os resultados analisados estatisticamente através do teste ANOVA, a dois critérios. Além disso, os fatores de interação fotopolimerização para resina composta e para sistema adesivo foram incluídos em cada modelo de análise. A distribuição dos dentes utilizados nos grupos experimentais foi considerada aleatória. As comparações intergrupos foram realizadas com o teste Tukey a um nível de significância de $5 \%$. 


$$
\text { 5- }
$$

Rociultadnc 


\section{5- Resultados}

\section{1- Cinética de conversão de monômeros}

No Anexo 1 encontram-se reunidos os resultados para os diferentes parâmetros utilizados para a avaliação da cinética da conversão dos monômeros para Adper Single Bond. No Anexo 2 encontram-se reunidos os resultados para os diferentes parâmetros utilizados para a avaliação da cinética de conversão monômeros para base da resina composta Filtek Z250 nos corpos de prova avaliados com espectrofotometria. No Anexo 3 encontram-se os resultados da cinética de conversão para os valores de topo, como termo de comparação.

\subsection{1- Conversão total de monômeros}

$\mathrm{Na}$ tabela a seguir (Tabela 5) estão contidos os resultados, bem como a análise estatística (ANOVA, a um critério), para porcentagem da conversão de monômeros em polímeros após o tempo de 300 segundos. Os resultados foram comparados levando-se em consideração as diferentes fontes de luz fotoativadora.

Tabela 5 - Porcentagem de conversão de monômeros após 300 segundos (Tukey; $p<0,05$ )

\begin{tabular}{|c|c|c|}
\hline Fonte de Luz & Adper Single Bond & Filtek Z250 Base \\
\hline $\begin{array}{c}\text { QTH } \\
\left(540 \mathrm{~mW} / \mathrm{cm}^{2}\right)\end{array}$ & $98,1(2,0)^{\mathrm{a}, \mathrm{c}}$ & $44,3(0,7)^{\mathrm{a}}$ \\
\hline $\begin{array}{c}\text { LED } \\
\left(750 \mathrm{~mW} / \mathrm{cm}^{2}\right)\end{array}$ & $93,8(3,0)^{\mathrm{c}, \mathrm{d}}$ & $45,5(1,1)^{\mathrm{a}}$ \\
\hline $\begin{array}{c}\text { PAC } \\
\left(2.130 \mathrm{~mW} / \mathrm{cm}^{2}\right)\end{array}$ & $92,2(3,9)^{\mathrm{b}, \quad \mathrm{d}}$ & $49,2(0,7)^{\mathrm{b}}$ \\
\hline $\begin{array}{c}\mathrm{n}=5 \\
\text { Letras sobrescritas diferentes }(a) \mathrm{e}(\mathrm{b})=\text { diferença significante }(p<0,05)\end{array}$
\end{tabular}

Pela análise da Tabela 5 verificou-se que a porcentagem de conversão de monômeros na resina para QTH e LED foi significantemente menor que os valores 
apresentados para PAC. Em relação ao sistema adesivo, QTH apresentou os maiores valores de conversão, sendo significantemente maiores que os apresentados quando se utilizou PAC.

Na Figura 49 são apresentados os resultados para sistema adesivo e para resina composta (base), possibilitando a observação da relação dos valores de conversão com a densidade de potência das unidades de luz fotoativadora. Observa-se que houve uma relação inversa entre a densidade de potência dos aparelhos e a conversão de monômeros no sistema adesivo. Utilizando-se PAC, a conversão foi menor, havendo diferença estatística em relação ao QTH que apresentou maiores valores de conversão. Já em relação à resina composta na base, houve uma relação direta. Quanto maior a densidade de potência, maior foi a conversão, havendo diferença significante entre os valores de PAC e os de QTH e LED, que foram significantemente menores.

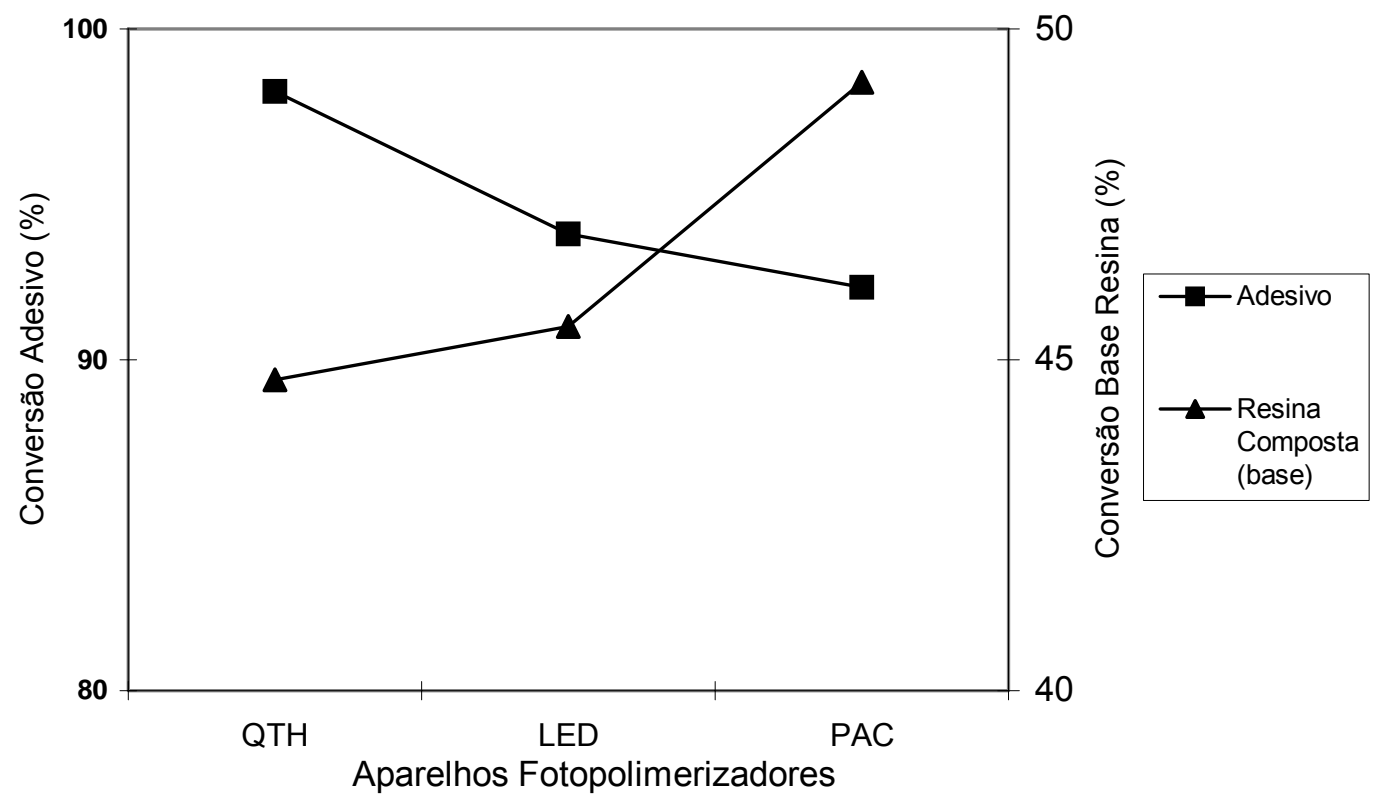

Figura 49 - Influência da luz fotoativadora na conversão de monômeros do sistema adesivo e da resina composta (base) 


\subsection{2- Taxa máxima de conversão}

Na Tabela 6 observam-se os valores para taxa máxima de conversão, em porcentagem por segundo, bem como a análise estatística. Para o sistema adesivo e para a resina composta (base) houve uma relação direta entre a densidade de potência e a taxa de conversão. Quanto maior a densidade de potência dos aparelhos de luz, maior a velocidade com que os monômeros se transformam em polímeros. No sistema adesivo, os valores de PAC foram significantemente maiores que os de LED e QTH ( $p<0,05)$. Na resina composta (base), os valores de PAC foram significantemente maiores que os do LED, que por sua vez foram significantemente maiores que os de QTH $(p<0,05)$.

Tabela 6 - Taxa máxima de conversão em porcentagem por segundo (Tukey, $p<0,05$ )

\begin{tabular}{|c|c|c|}
\hline Fonte de Luz & Adper Single Bond & Filtek Z250 Base \\
\hline $\begin{array}{c}\text { QTH } \\
\left(540 \mathrm{~mW} / \mathrm{cm}^{2}\right)\end{array}$ & $14,6(0,8)^{\mathrm{a}}$ & $5,3(0,5)^{\mathrm{d}}$ \\
\hline $\begin{array}{c}\text { LED } \\
\left(750 \mathrm{~mW} / \mathrm{cm}^{2}\right)\end{array}$ & $14,9(0,9)^{\mathrm{a}}$ & $6,8(0,9)^{\mathrm{e}}$ \\
\hline $\begin{array}{c}\mathrm{PAC} \\
\left(2.130 \mathrm{~mW} / \mathrm{cm}^{2}\right)\end{array}$ & $16,6(1,3)^{\mathrm{b}}$ & $9,8(1,1)^{\mathrm{f}}$ \\
\hline $\begin{array}{c}\mathrm{n}=5 \\
\text { Diferentes letras sobrescritas: diferença significante }\end{array}$ \\
\hline
\end{tabular}

5.1.3- Tempo em que ocorreu a máxima taxa de conversão

Na Tabela 7 observa-se o tempo em que ocorreu a taxa máxima de conversão de acordo com a fonte de luz utilizada, em segundos, bem como a análise estatística. 
Tabela 7 - Tempo em que ocorreu a máxima taxa de conversão em segundos (Tukey; $p<$ $0,05)$

\begin{tabular}{|c|c|c|}
\hline Fonte de Luz & Adper Single Bond & Filtek Z250 Base \\
\hline \begin{tabular}{c|c|}
\hline QTH \\
$\left(540 \mathrm{~mW} / \mathrm{cm}^{2}\right)$
\end{tabular} & $6,0(0,7)^{\mathrm{a}, \mathrm{c}}$ & $5,6(0,5)^{\mathrm{a}}$ \\
\hline $\begin{array}{c}\text { LED } \\
\left(750 \mathrm{~mW} / \mathrm{cm}^{2}\right)\end{array}$ & $5,4(0,9)^{\mathrm{c}, \mathrm{d}}$ & $4,2(0,8)^{\mathrm{b}}$ \\
\hline $\begin{array}{c}\mathrm{PAC} \\
\left(2.130 \mathrm{~mW} / \mathrm{cm}^{2}\right)\end{array}$ & $4,0(1,0)^{\mathrm{b}, \quad d}$ & $3,2(0,4)^{\mathrm{b}}$ \\
\hline $\begin{array}{c}\mathrm{n}=5 \\
\text { Diferentes letras sobrescritas (a) e (b): diferença significante }\end{array}$
\end{tabular}

Para resina composta (base), o tempo em que ocorreu a taxa máxima de conversão foi significantemente maior para QTH quando comparado a LED e PAC. Quando se comparou o tempo em ocorreu a taxa máxima de conversão para o sistema adesivo, os valores de PAC foram significantemente menores que para QTH.

\subsection{4- Conversão de monômeros na máxima taxa}

Na tabela a seguir (Tabela 8) estão contidos os valores para conversão de monômeros na máxima taxa. De acordo com a análise estatística realizada, verificou-se que não houve diferença estatisticamente significante para as diferentes condições experimentais. Independente da fonte de luz utilizada, não houve diferença na conversão na máxima taxa para os materiais utilizados. 
Tabela 8 - Conversão de monômeros na máxima taxa em porcentagem

\begin{tabular}{|c|c|c|}
\hline Fonte de Luz & Adper Single Bond & Filtek Z250 Base \\
\hline $\begin{array}{c}\text { QTH } \\
\left(540 \mathrm{~mW} / \mathrm{cm}^{2}\right)\end{array}$ & $44,8(7,7)^{\mathrm{a}}$ & $11,3(3,2)^{\mathrm{b}}$ \\
\hline $\begin{array}{c}\mathrm{LED} \\
\left(750 \mathrm{~mW} / \mathrm{cm}^{2}\right)\end{array}$ & $45,4(10,5)^{\mathrm{a}}$ & $12,9(2,1)^{\mathrm{b}}$ \\
\hline $\begin{array}{c}\mathrm{PAC} \\
\left(2.130 \mathrm{~mW} / \mathrm{cm}^{2}\right)\end{array}$ & $34,4(4,7)^{\mathrm{a}}$ & $11,9(3,4)^{\mathrm{b}}$ \\
\hline $\begin{array}{c}\mathrm{n}=5 \\
\text { Letras sobrescritas iguais= diferença não significante }(\mathrm{p}>0,05)\end{array}$ \\
\hline
\end{tabular}

\subsection{5- Relação conversão na máxima taxa e conversão total}

Para que se obtivessem os valores contidos na tabela a seguir, dividiram-se os valores obtidos na porcentagem de conversão que ocorre na máxima taxa pelos valores de conversão total após 300 segundos. Estes valores constituíram importante parâmetro de comparação entre as condições experimentais. Os resultados destes cálculos estão contidos na Tabela 9. Para o sistema adesivo e a resina composta (base), os valores foram maiores para o aparelho LED, sendo que quando se utilizou o aparelho PAC, os valores foram os menores, comparados a QTH e LED.

Tabela 9 - Influência da fonte de luz fotoativadora na relação conversão na máxima taxa e a conversão total em porcentagem

\begin{tabular}{|c|c|c|}
\hline Fonte de Luz & Adper Single Bond & Filtek Z250 Base \\
\hline $\begin{array}{c}\text { QTH } \\
\left(540 \mathrm{~mW} / \mathrm{cm}^{2}\right)\end{array}$ & 45,6 & 25,3 \\
\hline $\begin{array}{c}\text { LED } \\
\left(750 \mathrm{~mW} / \mathrm{cm}^{2}\right)\end{array}$ & 48,4 & 28,3 \\
\hline $\begin{array}{c}\text { PAC } \\
\left(2.130 \mathrm{~mW} / \mathrm{cm}^{2}\right)\end{array}$ & 37,3 & 24,2 \\
\hline
\end{tabular}


A Figura 50 apresenta os valores de conversão de acordo com a fonte de luz utilizada para materiais. Desta forma pode-se verificar a interação das combinações de fontes de luz. Utilizando-se do LED para ambos o sistema adesivo e para resina composta (base) verificou-se uma maior conversão de monômeros na máxima taxa com relação à conversão total. PAC apresentou os menores resultados para ambos.

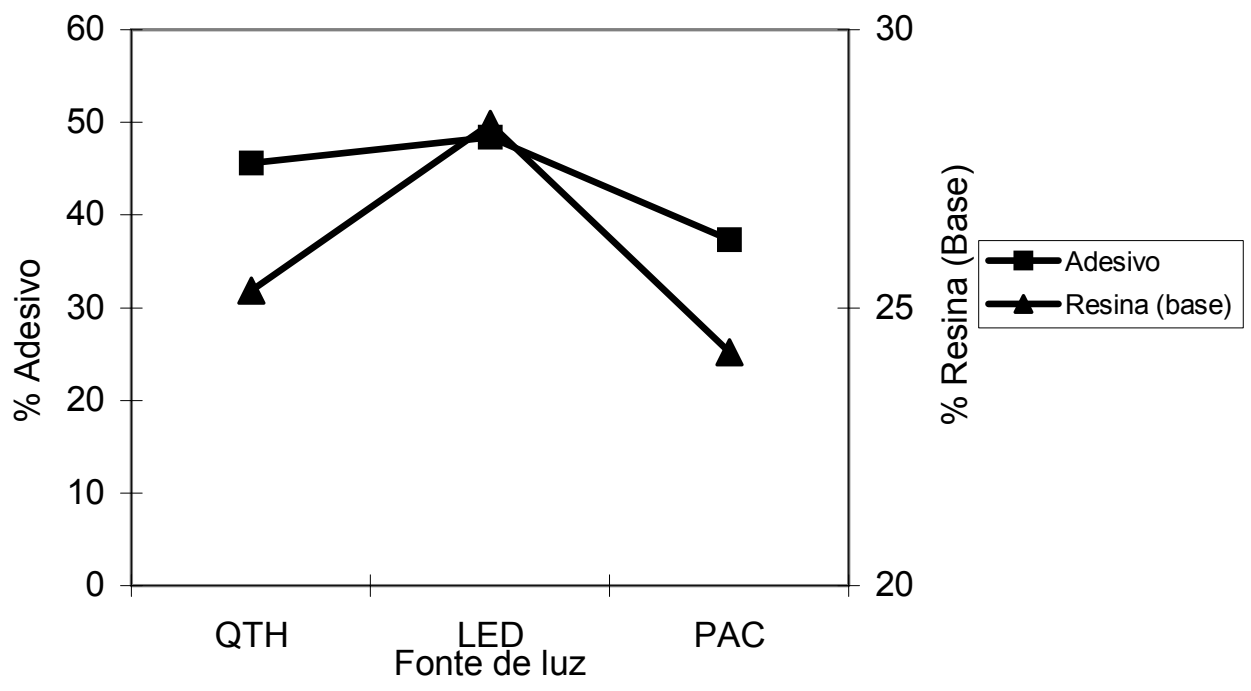

Figura 50 - Influência da fonte de luz fotoativadora na relação conversão na máxima taxa e a conversão total em porcentagem 
5.2- Análise da Interface Adesiva com Microscopia de Fluorescência

\subsection{1- Espessura de Camada de Adesivo}

$\mathrm{Na}$ tabela a seguir (Tabela 10), estão contidos os valores médios de espessura, em $\mu \mathrm{m}$, de camada de adesivo nos diferentes grupos experimentais. Os valores médios foram também analisados estatisticamente.

Tabela 10 - Valores de espessura da camada de adesivo e comparações estatísticas entre os diferentes grupos experimentais

\begin{tabular}{|c|c|}
\hline Grupo & $\begin{array}{c}\text { Espessura da Camada } \\
\text { de Adesivo } \\
(\text { em } \mu \mathrm{m})\end{array}$ \\
\hline QTH / QTH & $5,07(2,26)^{\mathrm{a}, \mathrm{c}}$ \\
\hline QTH / LED & $6,08(4,56)^{\mathrm{a}, \mathrm{c}}$ \\
\hline QTH / PAC & $8,64(3,77)^{\mathrm{c}, \mathrm{d}}$ \\
\hline LED / LED & $5,27(2,63)^{\mathrm{a}, \mathrm{c}}$ \\
\hline LED / QTH & $6,90(1,68)^{\mathrm{c}, \mathrm{d}}$ \\
\hline \hline LED / PAC & $7,87(2,79)^{\mathrm{c}, \mathrm{d}}$ \\
\hline PAC / PAC & $9,78(3,61)^{\mathrm{c}, \mathrm{d}}$ \\
\hline PAC / QTH & $11,91(3,59)^{\mathrm{b}, \mathrm{d}}$ \\
\hline PAC / LED & $8,97(2,61)^{\mathrm{c}, \mathrm{d}}$ \\
\hline
\end{tabular}

Valores em parêntesis: desvio-padrão

Letras sobrescritas diferentes (a) e (b): diferença significante $(p<0,05)$

A combinação PAC/QTH apresentou os maiores valores de espessura de camada de adesivo, sendo estatisticamente significante em comparação às combinações QTH/QTH, QTH/LED e LED/LED.

$\mathrm{Na}$ Tabela 11 observa-se a influência das diferentes fontes de luz fotoativadoras nos dois materiais testados de forma independente. Da análise dos 
resultados, pode-se verificar que houve valores significantemente maiores de espessura da camada de adesivo quando se utilizou PAC para o sistema adesivo $(p<0,05)$ comparado aos de LED e QTH. Diferentemente do sistema adesivo, verificou-se que não houve influência da fonte de luz fotoativadora da resina composta sobre a espessura da camada de adesivo formada.

Tabela 11 - Influência da fonte de luz fotoativadora sobre a espessura da camada de adesivo

\begin{tabular}{|c|c|c|c|c|c|c|}
\hline \multirow{2}{*}{$\begin{array}{l}\text { Fonte } \\
\text { de Luz }\end{array}$} & \multicolumn{2}{|c|}{ QTH } & \multicolumn{2}{|c|}{ LED } & \multicolumn{2}{|c|}{ PAC } \\
\hline & $\begin{array}{l}\text { Sistema } \\
\text { Adesivo }\end{array}$ & $\begin{array}{c}\text { Resina } \\
\text { Composta }\end{array}$ & $\begin{array}{l}\text { Sistema } \\
\text { Adesivo }\end{array}$ & $\begin{array}{c}\text { Resina } \\
\text { Composta }\end{array}$ & $\begin{array}{l}\text { Sistema } \\
\text { Adesivo }\end{array}$ & $\begin{array}{c}\text { Resina } \\
\text { Composta }\end{array}$ \\
\hline QTH & & & 0,9943 & 0,3838 & & \\
\hline LED & & & & & $0,0009^{*}$ & 0,0774 \\
\hline PAC & $0,0006^{*}$ & 0,6405 & & & & \\
\hline
\end{tabular}

${ }^{*}$ significante $(p<0,05)$

\subsection{2- Espessura de Camada Híbrida}

$\mathrm{Na}$ tabela a seguir (Tabela 12), estão contidos os valores médios de espessura, em $\mu \mathrm{m}$, de camada híbrida nos diferentes grupos experimentais assim como as comparações estatísticas entre eles. A análise de variância a dois critérios aplicada aos valores abaixo mostrou não haver diferença estatisticamente significante na espessura de camada híbrida entre os grupos experimentais. Quando se avaliou a influência da fonte de luz sobre a espessura de camada híbrida de forma independente, verificou-se que não houve influência da fonte de luz fotoativadora sobre os materiais restauradores avaliados (Tabela 13). 
Tabela 12 - Valores de espessura de camada híbrida e comparações estatísticas entre diferentes grupos experimentais

\begin{tabular}{|c|c|}
\hline Grupo & $\begin{array}{c}\text { Espessura de Camada } \\
\text { Híbrida } \\
(\mathrm{em} \mu \mathrm{m})\end{array}$ \\
\hline QTH / QTH & $4,02(0,58)$ \\
\hline QTH / LED & $4,70(0,72)$ \\
\hline QTH / PAC & $4,58(1,16)$ \\
\hline LED / LED & $3,81(0,67)$ \\
\hline LED / QTH & $3,92(0,97)$ \\
\hline LED / PAC & $3,66(0,56)$ \\
\hline PAC / PAC & $4,22(0,75)$ \\
\hline PAC / QTH & $3,84(0,91)$ \\
\hline PAC / LED & $3,98(0,81)$ \\
\hline
\end{tabular}

Valores em parêntesis desvio-padrão

Diferença não significante $(p>0,05)$

Tabela 13 - Influência da fonte de luz fotoativadora sobre a espessura da camada híbrida

\begin{tabular}{|c|c|c|c|c|c|c|}
\hline \multirow{2}{*}{$\begin{array}{c}\text { Fonte } \\
\text { de Luz }\end{array}$} & \multicolumn{2}{|c|}{ QTH } & \multicolumn{2}{c|}{ LED } & \multicolumn{2}{c|}{ PAC } \\
\cline { 2 - 7 } & Adesivo & $\begin{array}{c}\text { Resina } \\
\text { Composta }\end{array}$ & $\begin{array}{c}\text { Sistema } \\
\text { Adesivo }\end{array}$ & $\begin{array}{c}\text { Resina } \\
\text { Composta }\end{array}$ & $\begin{array}{c}\text { Sistema } \\
\text { Adesivo }\end{array}$ & $\begin{array}{c}\text { Resina } \\
\text { Composta }\end{array}$ \\
\hline QTH & & & 0,2843 & 0,5222 & & 0,7794 \\
\hline LED & & & & & 0,9756 & \\
\hline PAC & 0,3886 & 0,9068 & & & & \\
\hline
\end{tabular}




\subsection{3- Qualidade da Camada Híbrida}

Na Tabela 14 estão descritos os resultados da avaliação da qualidade da camada híbrida nos diferentes grupos experimentais, de acordo com os escores préestabelecidos. Os valores contidos na tabela correspondem à média e foram estatisticamente analisados com o teste não-paramétrico Kruskal-Wallis.

Tabela 14 - Escores de qualidade de camada híbrida e comparações estatísticas entre os diferentes grupos experimentais

\begin{tabular}{|c|c|}
\hline Grupo & $\begin{array}{c}\text { Qualidade da } \\
\text { Camada Híbrida } \\
\text { (Média) }\end{array}$ \\
\hline QTH / QTH & $1,7(0,4)^{\mathrm{a}}$ \\
\hline QTH / LED & $1,6(0,3)^{\mathrm{a}}$ \\
\hline QTH / PAC & $1,6(0,3)^{\mathrm{a}}$ \\
\hline LED / LED & $1,7(0,4)^{\mathrm{a}}$ \\
\hline LED / QTH & $2,0(0,5)^{\mathrm{a}}$ \\
\hline LED / PAC & $2,0(0,4)^{\mathrm{a}}$ \\
\hline PAC / PAC & $1,9(0,8)^{\mathrm{a}}$ \\
\hline PAC / QTH & $2,0(0,4)^{\mathrm{a}}$ \\
\hline PAC / LED & $1,8(0,8)^{\mathrm{a}}$ \\
\hline
\end{tabular}

Valores em parêntesis: desvio-padrão

Letras sobrescritas iguais: diferença não significante $(p>0,05)$

Verificou-se que não houve diferença estatisticamente significante quando se compararam os valores de qualidade de camada híbrida. Verificou-se ainda que não houve influência da fonte de luz fotoativadora do sistema adesivo ou da resina composta de forma independente sobre a qualidade da camada híbrida formada (Tabela 15). 
Tabela 15 - Influência da fonte de luz fotoativadora sobre a qualidade da camada híbrida

\begin{tabular}{|c|c|c|c|c|c|c|}
\hline \multirow{2}{*}{$\begin{array}{c}\text { Fonte } \\
\text { de Luz }\end{array}$} & $\begin{array}{c}\text { QTH } \\
\text { Sistema } \\
\text { Adesivo }\end{array}$ & $\begin{array}{c}\text { Resina } \\
\text { Composta }\end{array}$ & $\begin{array}{c}\text { Sistema } \\
\text { Adesivo }\end{array}$ & $\begin{array}{c}\text { Resina } \\
\text { Composta }\end{array}$ & $\begin{array}{c}\text { Sistema } \\
\text { Adesivo }\end{array}$ & $\begin{array}{c}\text { Resina } \\
\text { Composta }\end{array}$ \\
\hline QTH & & & 0,2843 & 0,5222 & & \\
\hline LED & & & & 0,9756 & 0,7794 \\
\hline PAC & 0,3886 & 0,9068 & & & & \\
\hline
\end{tabular}

Na Tabela 16 estão distribuídas as porcentagens dos escores de qualidade de camada híbrida nos diferentes grupos experimentais.

Tabela 16 - Distribuição comparativa da porcentagem dos escores de qualidade de camada híbrida nos diferentes grupos experimentais

\begin{tabular}{|c|c|c|c|}
\hline Grupos & $\begin{array}{c}\text { Escore 1 } \\
\text { "alta" }\end{array}$ & $\begin{array}{l}\text { Escore 2 } \\
\text { "média" }\end{array}$ & $\begin{array}{l}\text { Escore 3 } \\
\text { "baixa" }\end{array}$ \\
\hline QTH/QTH & 34,5 & 49,1 & 16,4 \\
\hline \hline QTH/LED & 45,5 & 49,1 & 5,4 \\
\hline \hline QTH/PAC & 48,4 & 45,2 & 6,4 \\
\hline \hline LED/LED & 44,1 & 41,2 & 14,7 \\
\hline LED/QTH & 27,8 & 44,5 & 27,7 \\
\hline LED/PAC & 24,2 & 40,3 & 35,5 \\
\hline PAC/PAC & 54,7 & 17,2 & 28,1 \\
\hline PAC/QTH & 44,3 & 31,7 & 24,0 \\
\hline PAC/LED & 44,9 & 27,5 & 27,6 \\
\hline
\end{tabular}


Pela análise da tabela acima, observa-se que a combinação PAC/PAC apresentou a maior porcentagem de escores de alta qualidade. A combinação LED/PAC, por sua vez, apresentou a maior porcentagem de piores escores ("baixa" qualidade). Na Figura $\mathbf{5 1}$ está a distribuição dos escores de alta qualidade de camada híbrida em ordem decrescente. Na Figura 52 observa-se a distribuição dos escores de baixa qualidade de camada híbrida em ordem decrescente. LED/QTH e LED/PAC apresentaram as menores porcentagens de alta qualidade, sendo que PAC/PAC e QTH/PAC apresentaram as maiores porcentagens. Observam-se, ainda, que as maiores porcentagens de escore 3 ocorreram nas combinações LED/PAC e PAC/PAC. As combinações QTH/LED e QTH/PAC apresentaram as menores porcentagens de baixa qualidade de camada híbrida. Comparando-se as combinações de mesma fonte de luz, PAC/PAC apresentou porcentagens bem maiores de baixa qualidade de camada híbrida quando comparadas às combinações QTH/QTH e LED/LED. Verifica-se que a combinação PAC/PAC apresentou valores extremos de melhor e pior escore para qualidade de camada híbrida, quando comparada às combinações QTH/QTH e LED/LED.

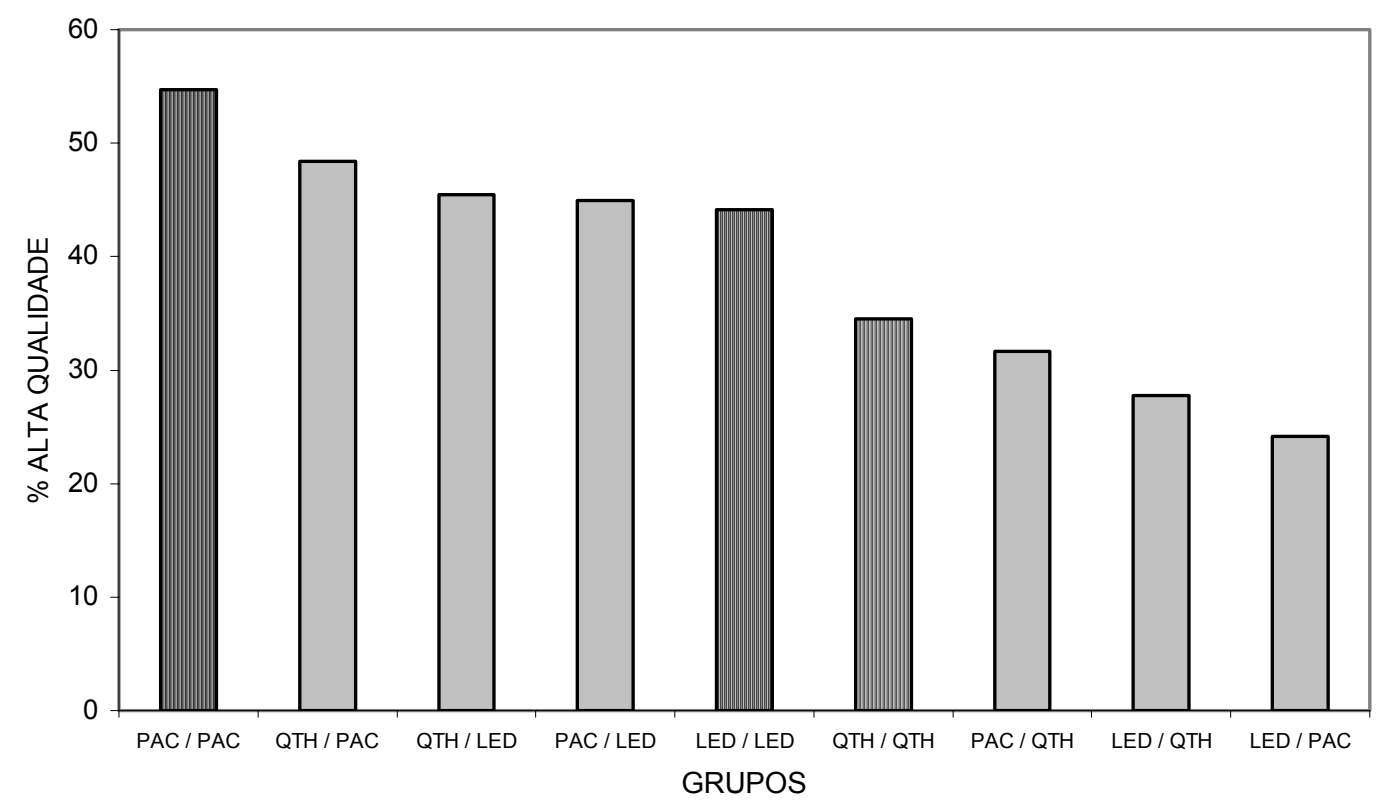

Figura 51 - Distribuição dos escores de alta qualidade de camada híbrida nos diferentes grupos experimentais 


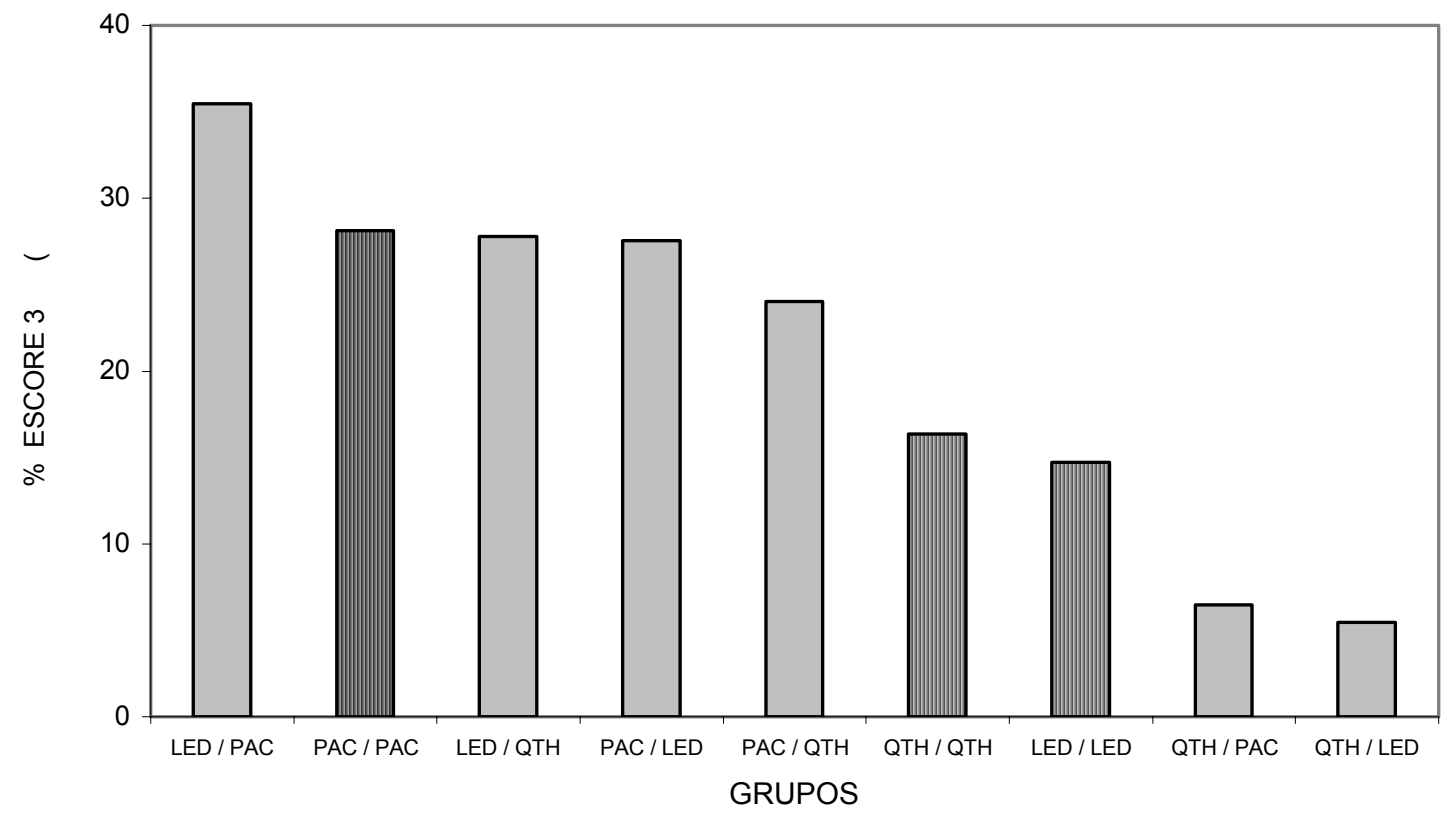

Figura 52 - Distribuição dos escores de baixa qualidade de camada híbrida nos diferentes grupos experimentais

\subsection{4- Teste de Micropermeabilidade}

$\mathrm{Na}$ Tabela 17 estão descritas as médias dos resultados do teste de micropermeabilidade nos diferentes grupos experimentais, de acordo com os escores pré-estabelecidos. Não houve diferença estatisticamente significante quando se compararam as médias finais dos diferentes grupos experimentais. Quando se comparou a influência das diferentes fontes de luz sobre os materiais restauradores avaliados independentemente também não se encontrou significância estatística (Tabela 18).

$\mathrm{Na}$ Tabela 19, a seguir, estão contidas as distribuições dos escores de micropermeabilidade nos diferentes grupos experimentais. Apesar de não haver diferença estatística entre os grupos, a combinação PAC/QTH apresentou as menores porcentagens de micropermeabilidade (escore 1) e a combinação LED/PAC, as maiores. 
Tabela 17 - Escores médios de micropermeabilidade e comparações estatísticas entre os diferentes grupos experimentais (Kruskal-Wallis)

\begin{tabular}{|c|c|}
\hline Grupo & $\begin{array}{c}\text { Teste de } \\
\text { Micropermeabilidade } \\
\text { (média) }\end{array}$ \\
\hline QTH / QTH & $1,84(0,8)^{\mathrm{a}}$ \\
\hline QTH / LED & $2,00(0,3)^{\mathrm{a}}$ \\
\hline QTH / PAC & $1,82(0,4)^{\mathrm{a}}$ \\
\hline LED / LED & $1,94(0,8)^{\mathrm{a}}$ \\
\hline LED / QTH & $1,78(0,9)^{\mathrm{a}}$ \\
\hline LED / PAC & $2,40(0,7)^{\mathrm{a}}$ \\
\hline PAC / PAC & $2,04(0,4)^{\mathrm{a}}$ \\
\hline \hline PAC / QTH & $1,68(0,2)^{\mathrm{a}}$ \\
\hline PAC / LED & $1,80(0,2)^{\mathrm{a}}$ \\
\hline
\end{tabular}

Valores em parêntesis desvio-padrão Letras sobrescritas iguais: diferença não significante $(p>0,05)$

Tabela 18 - Influência da fonte de luz fotoativadora sobre micropermeabilidade

\begin{tabular}{|c|c|c|c|c|c|c|}
\hline \multirow{2}{*}{$\begin{array}{c}\text { Fonte } \\
\text { de Luz }\end{array}$} & \multicolumn{2}{|c|}{ QTH } & \multicolumn{2}{c|}{ LED } & \multicolumn{2}{c|}{ PAC } \\
\cline { 2 - 7 } & Adesivo & $\begin{array}{c}\text { Resina } \\
\text { Composta }\end{array}$ & $\begin{array}{c}\text { Sistema } \\
\text { Adesivo }\end{array}$ & $\begin{array}{c}\text { Resina } \\
\text { Composta }\end{array}$ & $\begin{array}{c}\text { Sistema } \\
\text { Adesivo }\end{array}$ & $\begin{array}{c}\text { Resina } \\
\text { Composta }\end{array}$ \\
\hline QTH & & & 0,9863 & 0,7076 & & 0,5746 \\
\hline LED & & & & & 0,5981 & \\
\hline PAC & 0,6960 & 0,1814 & & & & \\
\hline
\end{tabular}


Tabela 19 - Distribuição da porcentagem dos escores de micropermeabilidade nos grupos experimentais

\begin{tabular}{|c|c|c|c|c|c|}
\hline GRUPOS & Escore 1 & Escore 2 & Escore 3 & Escore 4 & Escore 5 \\
\hline QTH/QTH & 63,6 & 13,5 & 15,8 & 5,8 & 1,3 \\
\hline QTH/LED & 47,1 & 19,1 & 26,5 & 4,0 & 3,3 \\
\hline QTH/PAC & 49,5 & 21,5 & 27,1 & 0,8 & 1,1 \\
\hline LED/LED & 50,0 & 11,6 & 25,4 & 7,9 & 5,1 \\
\hline LED/QTH & 64,0 & 9,5 & 21,5 & 2,3 & 2,7 \\
\hline \hline LED/PAC & 34,0 & 10,0 & 47,0 & 3,0 & 6,0 \\
\hline PAC/PAC & 43,0 & 19,0 & 38,0 & 1,0 & 0,0 \\
\hline PAC/QTH & 52,0 & 30,0 & 17,0 & 1,0 & 0,5 \\
\hline \hline PAC/LED & 33,7 & 9,5 & 44,7 & 3,2 & 5,8 \\
\hline
\end{tabular}

Nas figuras a seguir (Figuras 53 e 54) estão contidas as distribuições dos escores de micropermeabilidade. A Figura 53 contém a distribuição dos escores 1 e 2. Na Figura 54 contém a distribuição do escore 3 que constitui a micropermeabilidade da camada híbrida propriamente dita. Em ambos, as combinações QTH/QTH, LED/LED e PAC/PAC estão destacadas. Já na Figura 55, a distribuição da porcentagem dos escores 4 e 5 está agrupada, constituindo-se os piores escores em termos de micropermeabilidade. Neste caso a porcentagem dos escores está em ordem crescente nos diferentes grupos experimentais. 


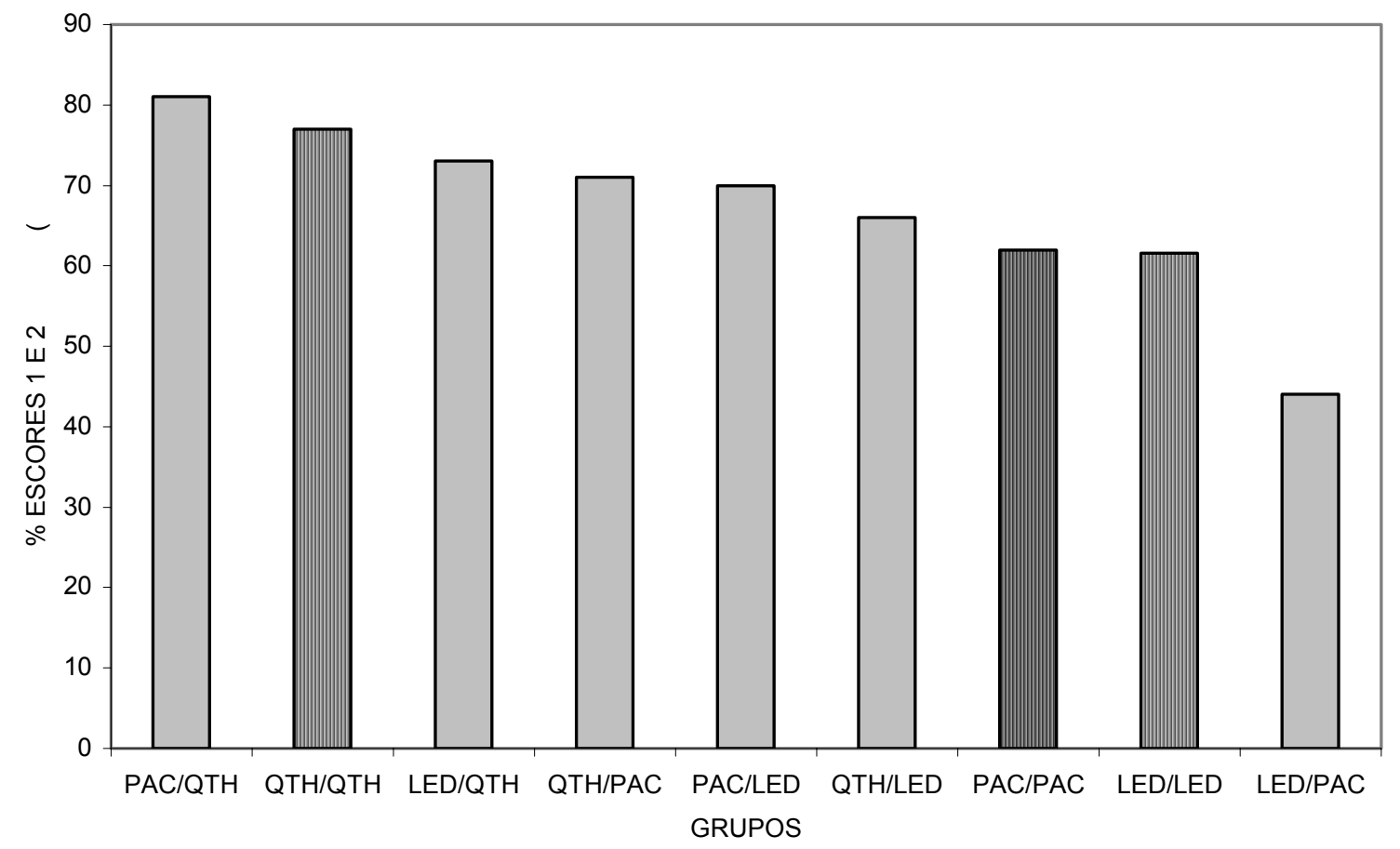

Figura 53- Distribuição decrescente dos escores 1 e 2 para micropermeabilidade nos grupos experimentais

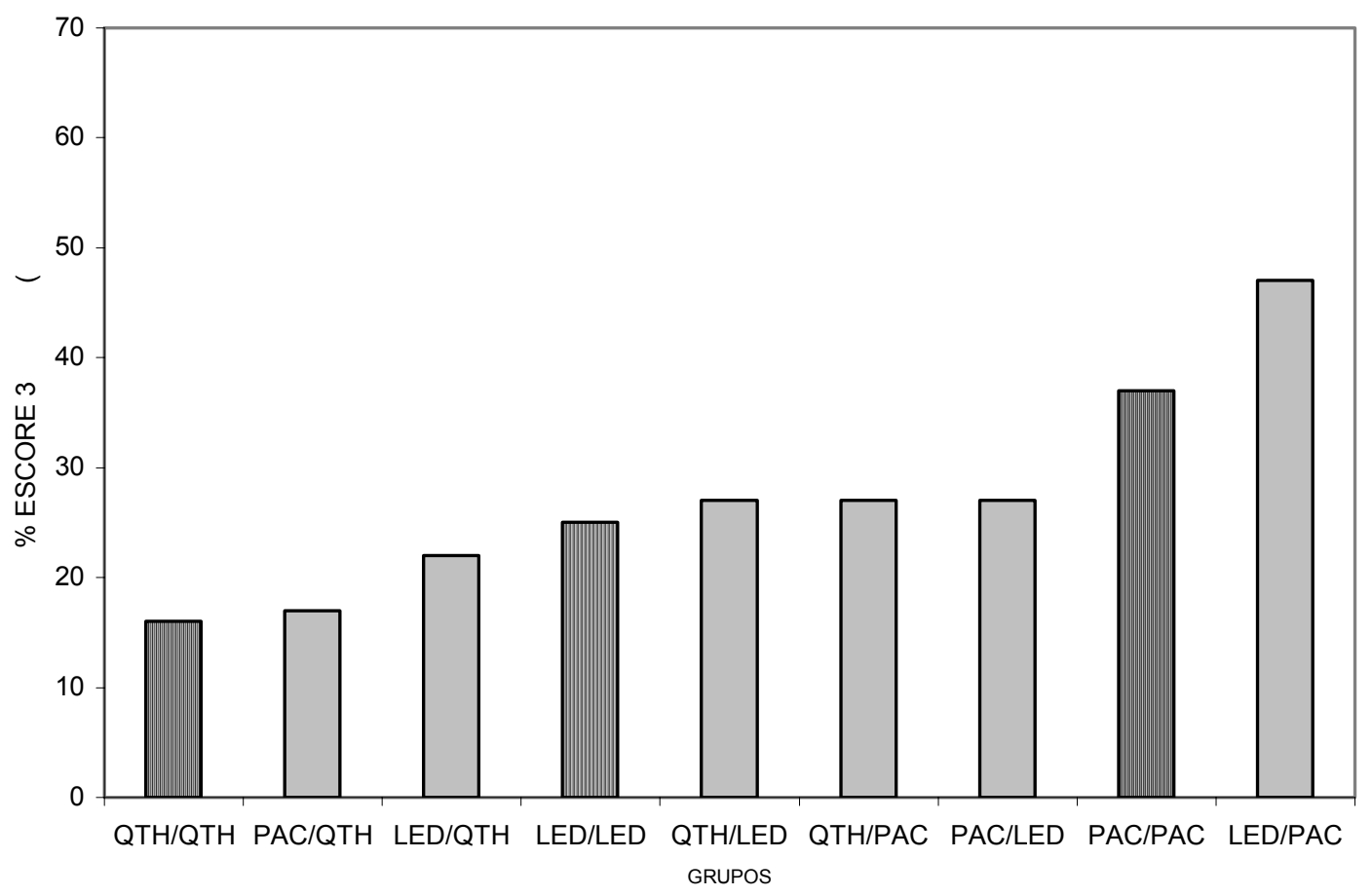

Figura 54 - Distribuição percentual de escore 3 para micropermeabilidade em ordem crescente nos grupos experimentais 
A Figura 53 demonstra que as combinações PAC/QTH e QTH/QTH apresentaram maiores porcentagens de escores 1 e 2. A combinação LED/PAC apresentou as menores porcentagens. Comparando-se as combinações com mesma fonte de luz, PAC/PAC e LED/LED apresentaram menores porcentagens de escores 1 e 2 em relação à QTH/QTH. Analisando a Figura 54, observa-se que as combinações QTH/QTH e PAC/QTH apresentaram as menores porcentagens de escore 3, sendo que a combinação LED/PAC apresentou as maiores porcentagens.

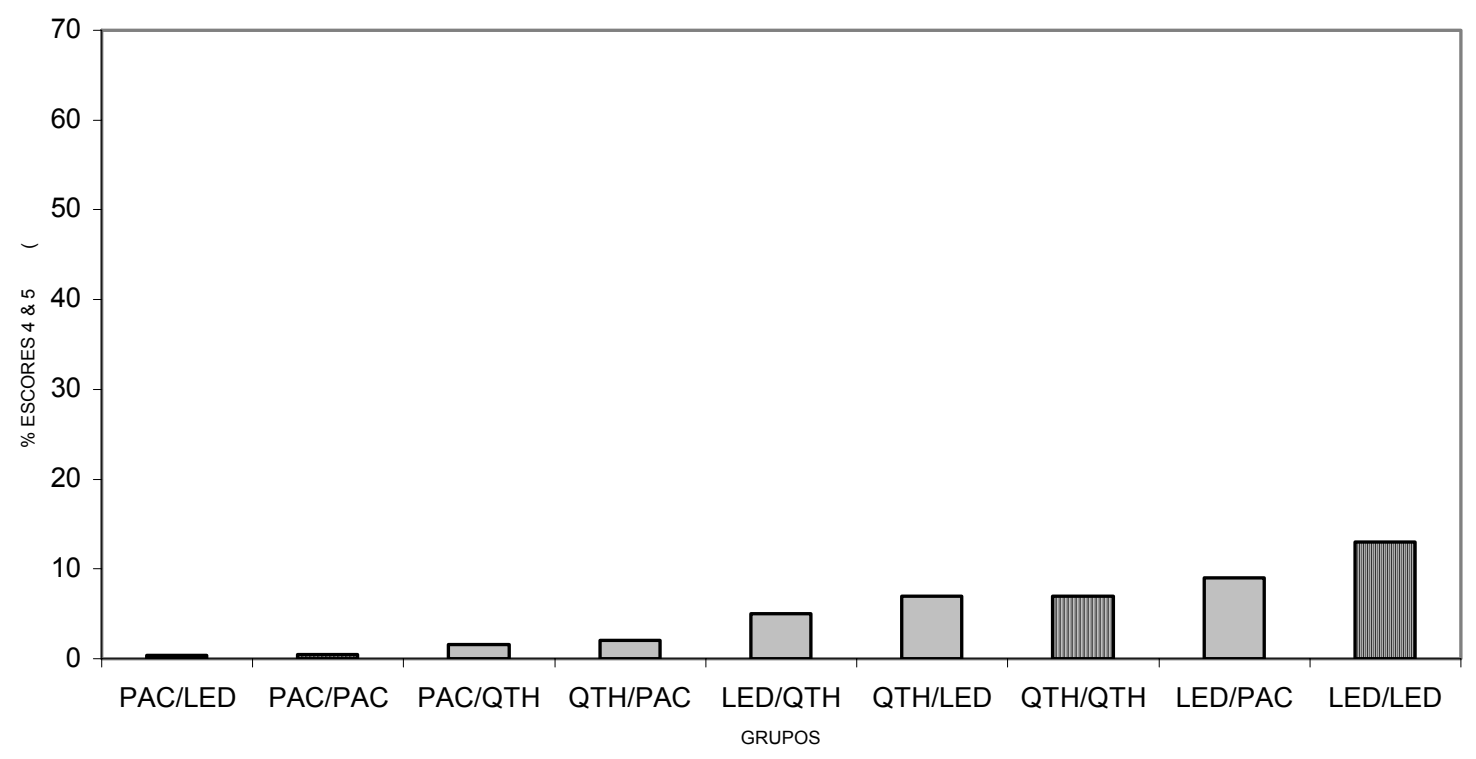

Figura 55 - Distribuição da porcentagem dos escores 4 e 5, em ordem crescente, de micropermeabilidade nos grupos experimentais

Comparando-se as combinações com mesma fonte de luz, verificou-se que QTH/QTH e LED/LED apresentaram menores porcentagens de presença de micropermeabilidade da camada híbrida propriamente dita em relação à combinação PAC/PAC. Quando se utilizou PAC para fotoativar o sistema adesivo, observaram-se menores porcentagens de escores 4 e 5 , independente da fonte de luz que fotopolimerizou a resina composta. As combinações LED/LED e LED/PAC apresentaram maiores porcentagens dos piores escores de micropermeabilidade. $A$ combinação PAC/PAC apresentou porcentagens bem menores destes escores quando comparadas às combinações QTH/QTH e LED/LED. 
5.2.5- Avaliação dos Tags de Resina

As médias dos escores de qualidade e habilidade de selamento dos tags de resina estão contidas na Tabela 20. A análise estatística revelou que não houve diferença significante entre os grupos experimentais. Analisando-se a influência das fontes de luz sobre os materiais restauradores de forma independente, também não se encontrou significância estatística (Tabelas 21 e 22).

Tabela 20 - Resultados da avaliação dos tags de resina nos diferentes grupos experimentais (Kruskal-Wallis)

\begin{tabular}{|c|c|c|}
\hline Grupo & $\begin{array}{c}\text { Qualidade } \\
\text { (Média) }\end{array}$ & $\begin{array}{c}\text { Habilidade de } \\
\text { Selamento } \\
\text { (Média) }\end{array}$ \\
\hline QTH / QTH & $1,6(0,3)^{a}$ & $1,7(0,7)^{a}$ \\
\hline QTH / LED & $1,7(0,3)^{a}$ & $2,1(0,5)^{a}$ \\
\hline QTH / PAC & $1,7(0,3)^{a}$ & $1,9(0,6)^{a}$ \\
\hline LED / LED & $1,8(0,4)^{a}$ & $1,9(0,6)^{a}$ \\
\hline LED / QTH & $2,0(0,6)^{a}$ & $1,9(0,7)^{a}$ \\
\hline LED / PAC & $2,0(0,7)^{a}$ & $2,2(0,7)^{a}$ \\
\hline PAC / PAC & $1,9(0,6)^{a}$ & $2,2(0,5)^{a}$ \\
\hline \hline PAC / QTH & $1,8(0,3)^{a}$ & $1,8(0,5)^{a}$ \\
\hline PAC / LED & $1,9(0,3)^{a}$ & $1,9(0,4)^{a}$ \\
\hline Valores em parêntesis desvio-padrão & \\
\hline Letras sobrescritas iguais: não significante $(p>0,05)$ \\
\hline
\end{tabular}


Tabela 21 - Influência da fonte de luz fotoativadora sobre a qualidade dos tags de resina

\begin{tabular}{|c|c|c|c|c|c|c|}
\hline \multirow{2}{*}{$\begin{array}{l}\text { Fonte } \\
\text { de Luz }\end{array}$} & \multicolumn{2}{|c|}{ QTH } & \multicolumn{2}{|c|}{ LED } & \multicolumn{2}{|c|}{ PAC } \\
\hline & $\begin{array}{l}\text { Sistema } \\
\text { Adesivo }\end{array}$ & $\begin{array}{c}\text { Resina } \\
\text { Composta }\end{array}$ & $\begin{array}{l}\text { Sistema } \\
\text { Adesivo }\end{array}$ & $\begin{array}{c}\text { Resina } \\
\text { Composta }\end{array}$ & $\begin{array}{l}\text { Sistema } \\
\text { Adesivo }\end{array}$ & $\begin{array}{c}\text { Resina } \\
\text { Composta }\end{array}$ \\
\hline QTH & & & 0,2825 & 0,9974 & & \\
\hline LED & & & & & 0,9433 & 0,9900 \\
\hline PAC & 0,4498 & 0,9773 & & & & \\
\hline
\end{tabular}

Valores não significantes $(p>0,05)$

Tabela 22 - Influência da fonte de luz fotoativadora sobre a habilidade de selamento dos tags de resina

\begin{tabular}{|c|c|c|c|c|c|c|}
\hline \multirow{2}{*}{$\begin{array}{l}\text { Fonte } \\
\text { de Luz }\end{array}$} & \multicolumn{2}{|c|}{ QTH } & \multicolumn{2}{|c|}{ LED } & \multicolumn{2}{|c|}{ PAC } \\
\hline & $\begin{array}{l}\text { Sistema } \\
\text { Adesivo }\end{array}$ & $\begin{array}{c}\text { Resina } \\
\text { Composta }\end{array}$ & $\begin{array}{l}\text { Sistema } \\
\text { Adesivo }\end{array}$ & $\begin{array}{c}\text { Resina } \\
\text { Composta }\end{array}$ & $\begin{array}{l}\text { Sistema } \\
\text { Adesivo }\end{array}$ & $\begin{array}{l}\text { Resina } \\
\text { Composta }\end{array}$ \\
\hline QTH & & & 0,8899 & 0,8944 & & \\
\hline LED & & & & & 0,9931 & 0,7011 \\
\hline PAC & 0,9352 & 0,4278 & & & & \\
\hline
\end{tabular}

Valores não significantes $(p>0,05)$

$\mathrm{Na}$ Tabela 23, a seguir, estão contidas as distribuições dos escores de qualidade dos tags de resina levando-se em consideração os diferentes grupos experimentais. Pode-se verificar que a combinação QTH/QTH apresentou a maior porcentagem dos melhores escores de qualidade de tags. A combinação LED/PAC apresentou as maiores porcentagens de escore 3. Quando se utilizou LED para sistema adesivo, independente da fonte de luz para resina composta, observaram-se maiores porcentagens de escore 3. Na Figura 56 a seguir, estão distribuídos, em ordem decrescente, os resultados de qualidade dos tags de resina nos diferentes grupos experimentais. Pela análise do gráfico, verifica-se que a fonte de luz que fotopolimeriza o sistema adesivo foi determinante na qualidade dos tags. Quando se 
utilizou LED para fotoativar o sistema adesivo, obtiveram-se as maiores porcentagens de escore 3 para qualidade de tags de resina, independente da fonte de luz fotoativadora da resina composta. Os valores de PAC foram intermediários, sendo que QTH obtiveram as menores porcentagens de escore 3 para tags de resina. Comparando-se combinações de mesma fonte de luz, observam-se valores menores para a combinação QTH/QTH, que foram bem menores que os de PAC/PAC, que por sua vez foram menores que os de LED/LED. Na Tabela 24, acima, estão distribuídas as porcentagens de escores para habilidade de selamento dos tags de resina. Pode-se verificar que a combinação QTH/QTH apresentou as maiores porcentagens de escore 1. A combinação LED/PAC apresentou as maiores porcentagens de piores escores (escore 3). As combinações PAC/PAC e LED/LED apresentaram maiores porcentagens de escore 3 quando comparados à combinação QTH/QTH.

Tabela 23 - Distribuição da porcentagem de escores de qualidade dos tags de resina nos diferentes grupos experimentais

\begin{tabular}{|c|c|c|c|}
\hline \multicolumn{1}{|c|}{ Grupos } & Escore 1 & Escore 2 & Escore 3 \\
\hline QTH/QTH & 52,7 & 38,2 & 9,1 \\
\hline \hline QTH/LED & 38,2 & 54,5 & 7,3 \\
\hline QTH/PAC & 38,7 & 53,2 & 8,1 \\
\hline LED/LED & 32,4 & 47,1 & 20,6 \\
\hline LED/QTH & 32,9 & 43,8 & 23,3 \\
\hline LED/PAC & 42,1 & 19,3 & 38,6 \\
\hline \hline PAC/PAC & 45,3 & 37,5 & 17,2 \\
\hline \hline PAC/QTH & 27,5 & 62,5 & 10,0 \\
\hline \hline PAC/LED & 29,0 & 50,7 & 20,3 \\
\hline
\end{tabular}




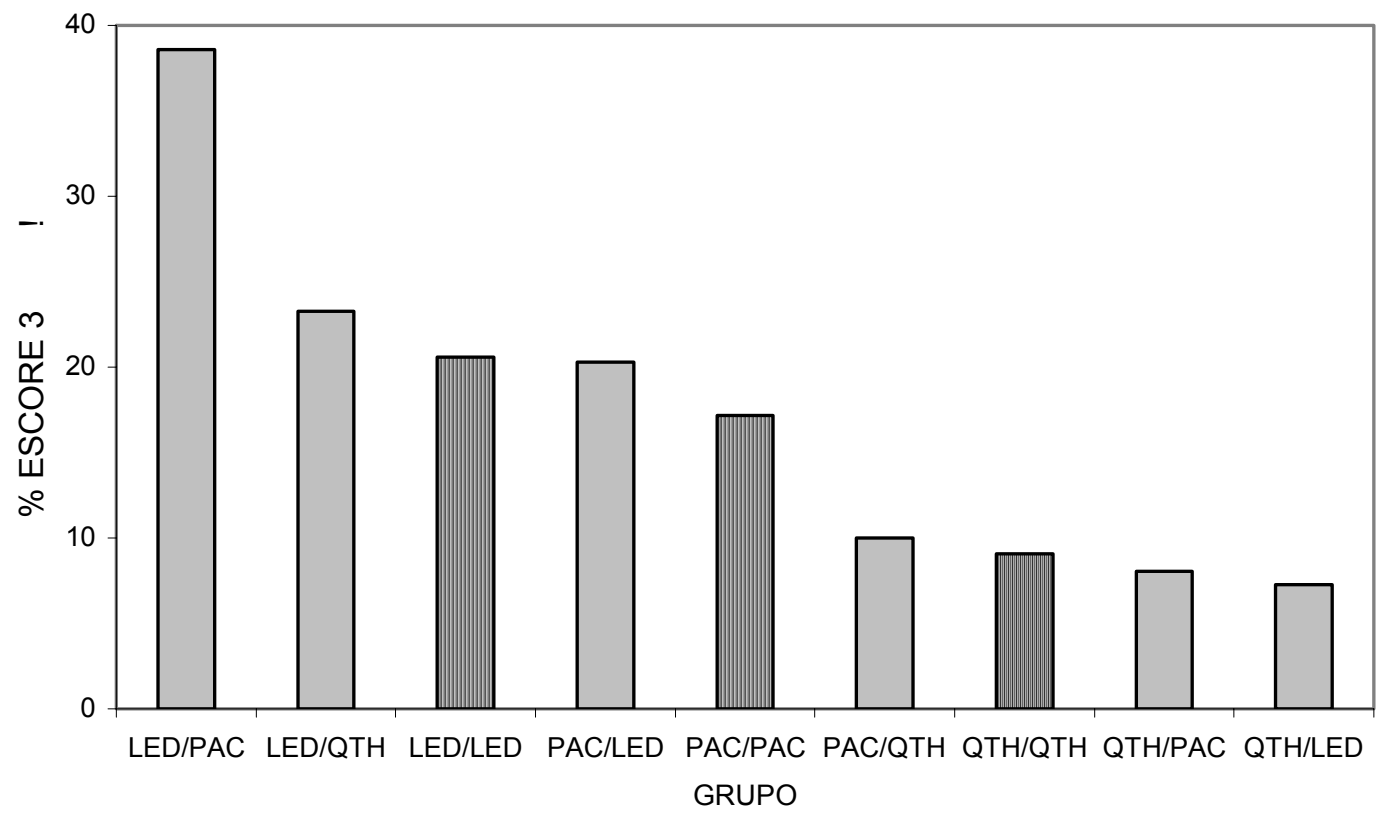

Figura 56 - Concentração de escore $3(\%)$ da qualidade dos tags de resina para os diferentes grupos experimentais, distribuídos em ordem decrescente

Tabela 24 - Porcentagem de escores de habilidade de selamento dos tags de resina nos diferentes grupos experimentais

\begin{tabular}{|c|c|c|c|}
\hline Grupos & Escore 1 & Escore 2 & Escore 3 \\
\hline QTH/QTH & 63,6 & 7,3 & 29,1 \\
\hline QTH/LED & 34,5 & 29,1 & 36,4 \\
\hline QTH/PAC & 46,8 & 12,9 & 40,3 \\
\hline LED/LED & 45,6 & 19,1 & 35,3 \\
\hline LED/QTH & 47,9 & 19,2 & 32,9 \\
\hline LED/PAC & 32,3 & 16,1 & 51,6 \\
\hline PAC/PAC & 25,0 & 37,5 & 37,5 \\
\hline PAC/QTH & 45,0 & 23,8 & 31,3 \\
\hline PAC/LED & 42,0 & 26,1 & 31,9 \\
\hline
\end{tabular}


$\mathrm{Na}$ Figura 57, a seguir, estão distribuídas as porcentagens de escore 3 para habilidade de selamento dos tags de resina nos diferentes grupos experimentais em ordem decrescente. Verifica-se que as combinações que utilizaram PAC para fotoativar a resina composta apresentaram menor habilidade de selamento dos tags de resina, independente da fonte de luz utilizada para fotoativar o sistema adesivo. Quando se utilizaram fontes de luz com menor densidade de potência para fotoativar a resina composta, a habilidade de selamento foi maior. Comparando-se as combinações de mesma fonte de luz, QTH/QTH apresentou menor porcentagem de escore 3 comparado às combinações PAC/PAC e LED/LED.

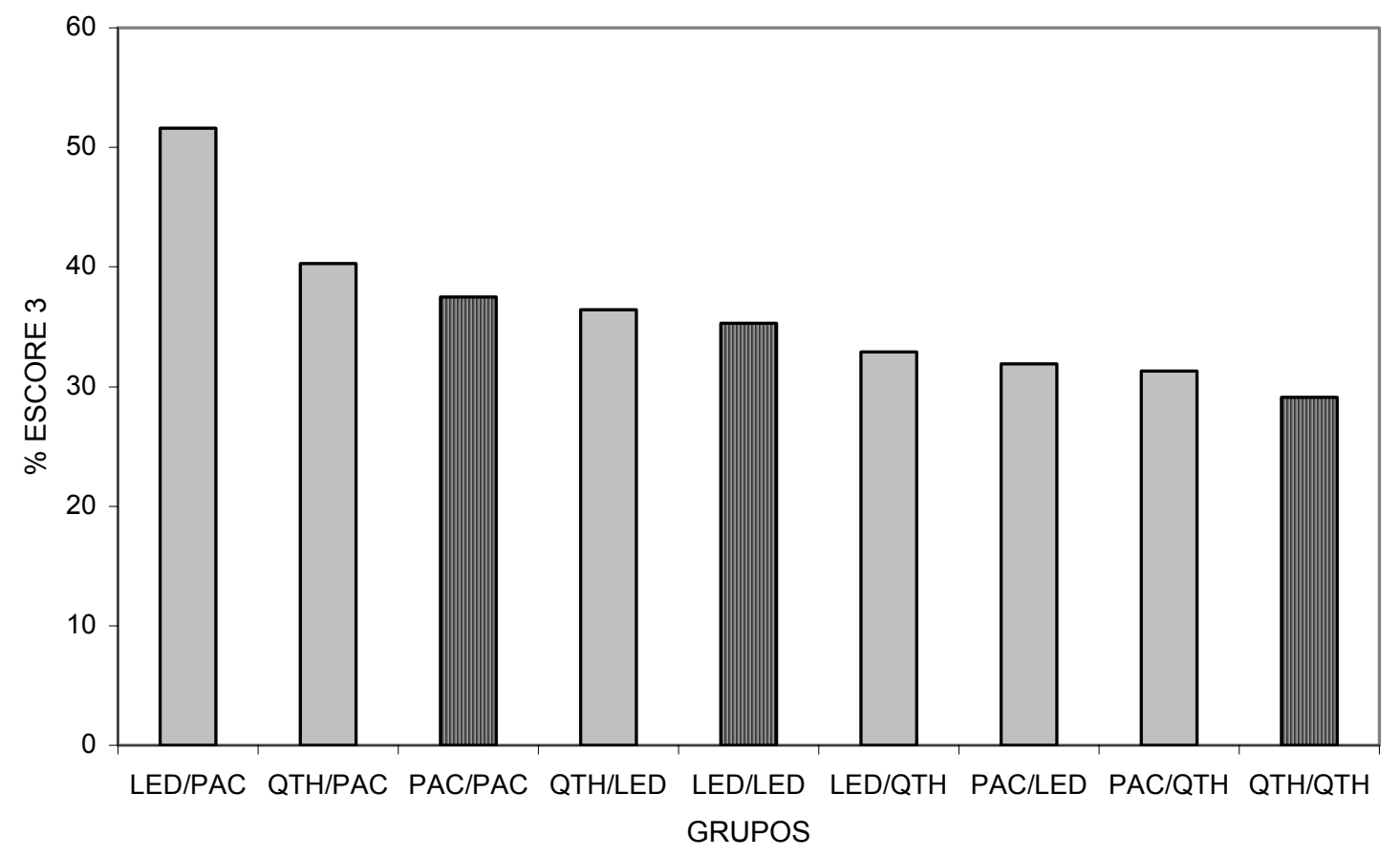

Figura 57 - Distribuição em ordem decrescente dos piores escores de habilidade de selamento dos tags de resina nos diferentes grupos experimentais 


\subsection{6- Avaliação de Fendas}

Na Tabela 25 encontram-se as médias dos escores de localização, bem como dos valores de extensão de fendas. Nesta tabela encontram-se ainda, os resultados da análise estatística.

Tabela 25- Resultados da avaliação da localização e extensão de fendas nos diferentes grupos experimentais

\begin{tabular}{|c|c|c|}
\hline Grupo & $\begin{array}{c}\text { Localização* } \\
\text { (Média) }^{*}\end{array}$ & $\begin{array}{c}\text { Extensão** } \\
(\text { em } \mu \mathrm{m})\end{array}$ \\
\hline QTH / QTH & $2,6(1,1)^{\mathrm{a}}$ & $35,80(43,13)$ \\
\hline QTH / LED & $2,7(0,8)^{\mathrm{a}}$ & $52,67(52,87)^{\mathrm{a}}$ \\
\hline \hline QTH / PAC & $2,0(0,4)^{\mathrm{a}}$ & $38,12(49,43)$ \\
\hline LED / LED & $3,0(1,2)^{\mathrm{a}}$ & $56,14(58,63){ }^{\mathrm{c}}$ \\
\hline LED / QTH & $2,6(1,7)^{\mathrm{a}}$ & $36,06(52,51)$ \\
\hline \hline LED / PAC & $2,6(0,8)^{\mathrm{a}}$ & $40,84(57,79)$ \\
\hline \hline PAC / PAC & $1,7(0,4)^{\mathrm{a}}$ & $19,14(27,27)^{\mathrm{b}, \mathrm{d}}$ \\
\hline \hline PAC / QTH & $1,4(0,3)^{\mathrm{a}}$ & $15,84(29,87)^{\mathrm{b}, \mathrm{d}}$ \\
\hline \hline PAC / LED & $1,7(0,3)^{\mathrm{a}}$ & $21,52(32,85){ }^{\mathrm{d}}$ \\
\hline
\end{tabular}

Números entre parênteses: desvio-padrão

*Letras sobrescritas iguais: diferença não significante (Dunnet's test; $p>0,05$ )

** Letras sobrescritas diferentes (a) e (b); (c) e (d): significante (Tukey test; $p<0,05$ )

A análise estatística revelou que houve interação entre a fonte de luz fotoativadora com o sistema adesivo $(F=6,28)$, quando se utilizou o teste de Dunnet para comparação intergrupos. Nas Tabelas 26 e 27 observa-se análise estatística da influência das fontes de luz sobre os materiais restauradores de forma independente. Na Tabela 26 observa-se que houve diferença significante quando se utilizou PAC para o sistema adesivo. Os valores de extensão de fendas foram 
significantemente menores quando se utilizou o PAC para fotoativar o sistema adesivo, comparados com os valores de LED e QTH. Verificou-se que houve diferença significante quando se compararam os valores de PAC com LED e com QTH. Os valores apresentados na Tabela 27 mostraram que não houve influência da fonte de luz que fotoativou a resina composta nos resultados finais de localização de fendas. Pode-se afirmar que os resultados de localização de fendas foram mais influenciado pela fonte de luz que fotoativa o sistema adesivo do que fotoativa a resina composta, sendo que PAC apresentou valores significantemente menores, comparados com LED e QTH.

Tabela 26- Influência da fonte de luz fotoativadora do sistema adesivo sobre a extensão de fendas

\begin{tabular}{|c|c|c|c|c|c|c|}
\hline \multirow{2}{*}{$\begin{array}{c}\text { Fonte } \\
\text { de Luz }\end{array}$} & \multicolumn{2}{|c|}{ QTH } & \multicolumn{2}{c|}{ LED } & \multicolumn{2}{c|}{ PAC } \\
\cline { 2 - 7 } & Localização & Extensão & Localização & Extensão & Localização & Extensão \\
\hline QTH & & & 0,8131 & 0,9435 & & \\
\hline LED & & & & & $0,0412^{*}$ & $0,0287^{*}$ \\
\hline PAC & $0,0091^{*}$ & $0,0129^{*}$ & & & & \\
\hline
\end{tabular}

${ }^{*}$ significante $(p<0,05)$

Tabela 27- Influência da fonte de luz fotoativadora da resina composta sobre a localização de fendas

\begin{tabular}{|c|c|l|l|l|l|l|}
\hline \multirow{2}{*}{$\begin{array}{c}\text { Fonte } \\
\text { de Luz }\end{array}$} & \multicolumn{2}{|c|}{ QTH } & \multicolumn{2}{c|}{ LED } & \multicolumn{2}{c|}{ PAC } \\
\cline { 2 - 7 } & Localização & Extensão & Localização & Extensão & Localização & Extensão \\
\hline QTH & & & 0,7737 & 0,4676 & & \\
\hline LED & & & & & 0,5075 & 0,5582 \\
\hline PAC & 0,9007 & 0,9876 & & & & \\
\hline
\end{tabular}

Valores não significantes $(p>0,05)$ 
$\mathrm{Na}$ tabela a seguir (Tabela 28) encontram-se as distribuições dos escores para localização de fendas.

Tabela 28- Distribuição da porcentagem de escores de localização de fendas nos diferentes grupos experimentais

\begin{tabular}{|c|c|c|c|c|c|c|c|}
\hline Combinações & $\begin{array}{c}\text { Escore } \\
1\end{array}$ & $\begin{array}{c}\text { Escore } \\
2\end{array}$ & $\begin{array}{c}\text { Escore } \\
3\end{array}$ & $\begin{array}{c}\text { Escore } \\
4\end{array}$ & $\begin{array}{c}\text { Escore } \\
5\end{array}$ & $\begin{array}{c}\text { Escore } \\
6\end{array}$ & $\begin{array}{c}\text { Escore } \\
7\end{array}$ \\
\hline QTH / QTH & 44,7 & 29,8 & 0,0 & 14,9 & 4,3 & 2,1 & 4,3 \\
\hline \hline QTH / LED & 46,2 & 13,5 & 0,0 & 21,1 & 7,7 & 3,8 & 7,7 \\
\hline QTH / PAC & 48,4 & 35,9 & 1,6 & 7,8 & 1,6 & 0,0 & 4,7 \\
\hline LED / LED & 34,4 & 26,6 & 0,0 & 12,5 & 7,8 & 4,7 & 14,0 \\
\hline LED / QTH & 45,6 & 29,4 & 0,0 & 8,8 & 4,4 & 2,9 & 8,8 \\
\hline \hline LED / PAC & 34,5 & 32,7 & 0,0 & 14,5 & 9,1 & 0,0 & 9,1 \\
\hline PAC / PAC & 48,3 & 43,1 & 3,4 & 3,4 & 0,0 & 0,0 & 1,7 \\
\hline PAC / QTH & 62,1 & 34,8 & 0,0 & 3,0 & 0,0 & 0,0 & 0,0 \\
\hline PAC / LED & 57,9 & 33,3 & 5,3 & 1,7 & 0,0 & 0,0 & 1,7 \\
\hline
\end{tabular}

Nas Figuras 58, 59 e 60 estão contidas as distribuições dos escores para localização de fendas nos diferentes grupos experimentais. Da análise da Figura 58, observa-se que quando se utilizou PAC para fotoativar o sistema adesivo, independente da fonte de luz que fotoativou a resina composta, observaram-se maiores porcentagens de escores 1 e 2. A combinação PAC/QTH apresentou a maior porcentagem de escores 1 e 2 (cerca de 96 \%). Na Figura 59, verifica-se que quando se utilizou LED tanto para resina composta como para o sistema adesivo (com exceção de PAC/LED), houve maiores porcentagens de escores 5, 6 e 7. Observa-se, ainda, que a combinação PAC/QTH não apresentou ocorrência destes escores. 


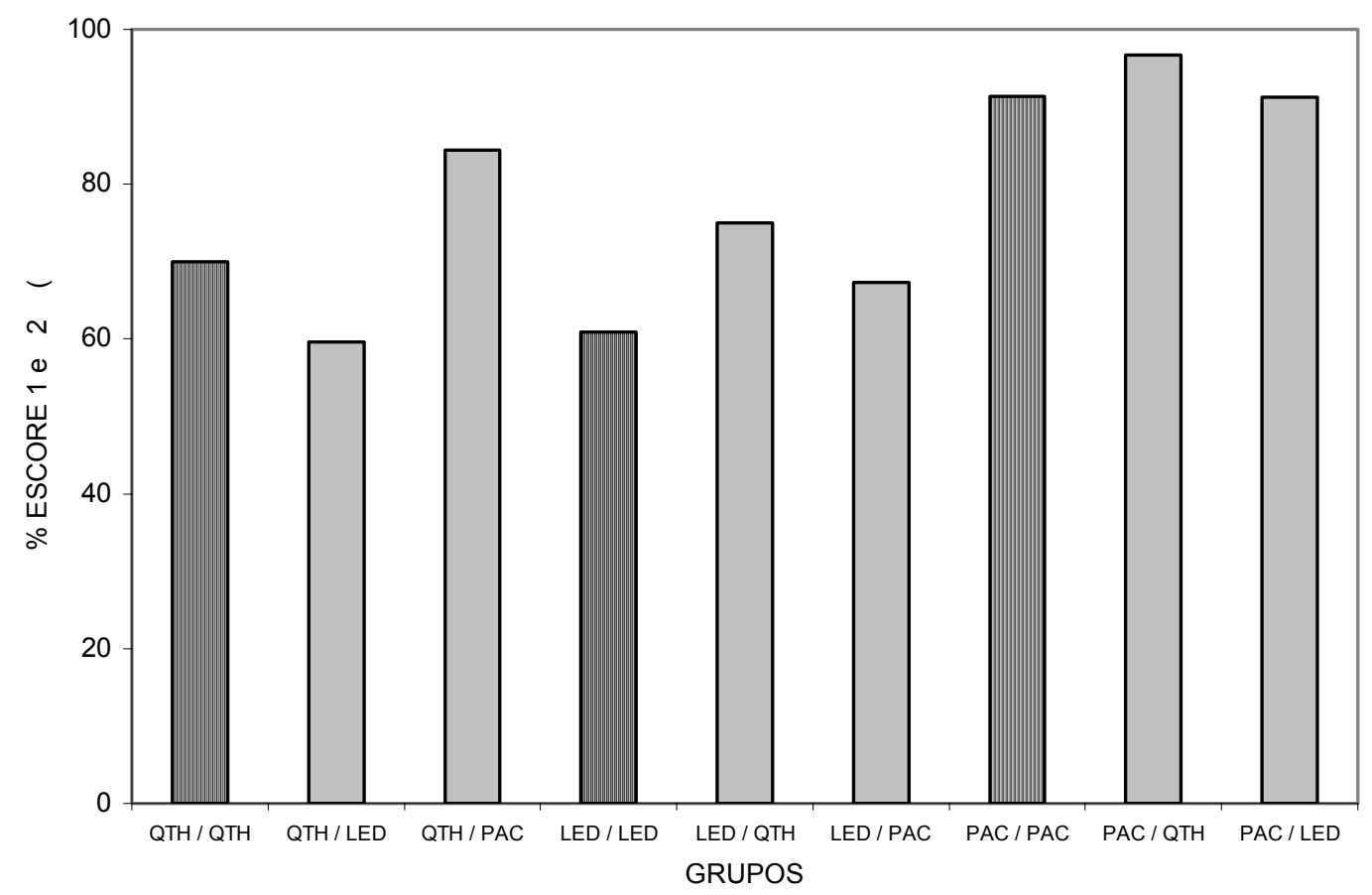

Figura 58 - Distribuição dos escores 1 e 2 para presença de fendas de acordo com as combinações de fonte de luz utilizadas

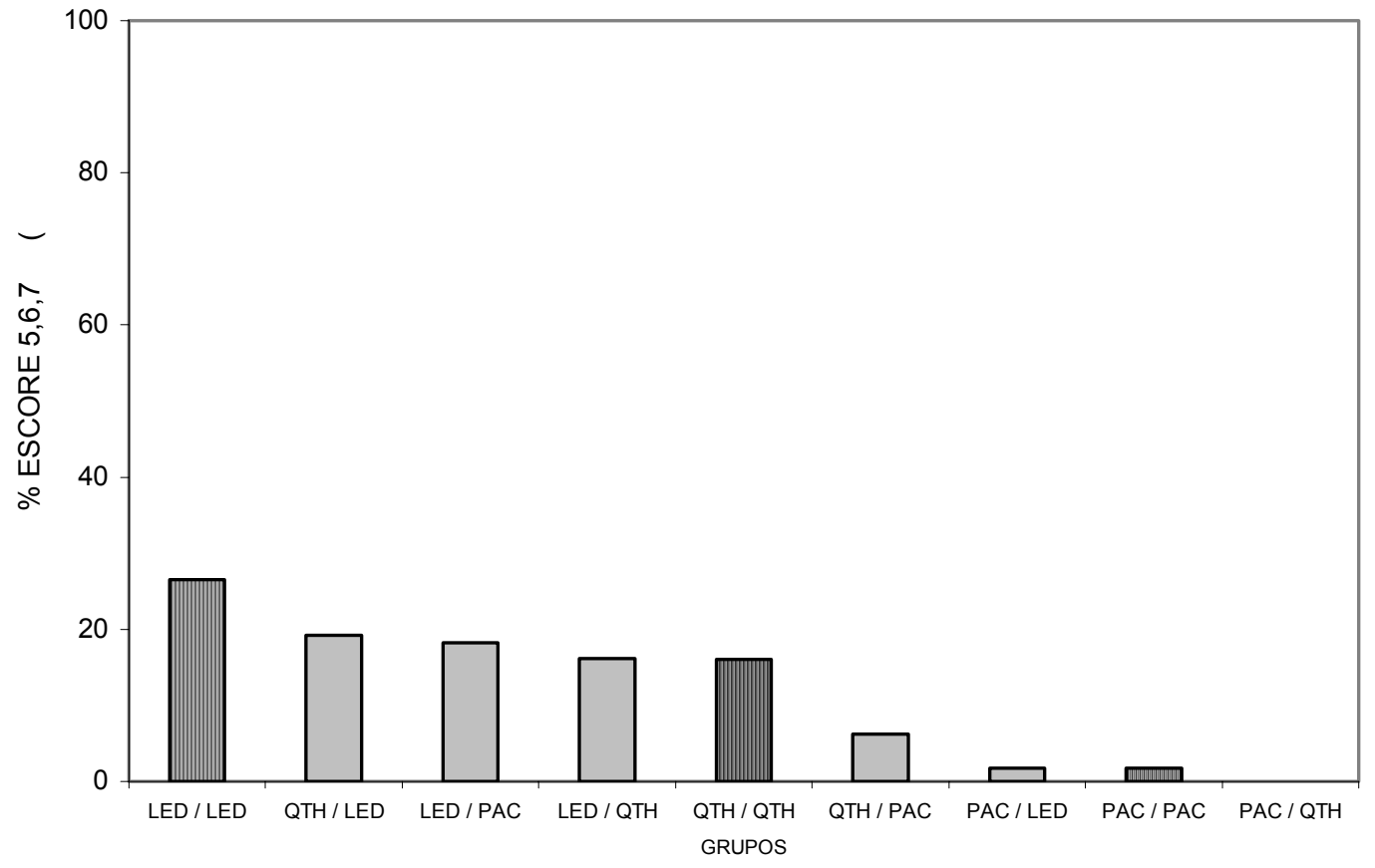

Figura 59 - Distribuição dos escores 5, 6 e 7 para presença de fendas em ordem decrescente 
$\mathrm{Na}$ Figura 60 observa-se a distribuição da presença de fendas entre a camada híbrida e a de adesivo, independente da presença do corante que foi aplicado na câmara pulpar. Verificou-se que a combinação QTH/LED apresentou a maior porcentagem dessa categoria de fenda (cerca de $30 \%$ ), comparada aos demais grupos. As combinações utilizando-se PAC para sistema adesivo apresentaram mais uma vez as menores porcentagens.

Na Figura 61 observam-se os valores de extensão de fendas em ordem decrescente de valores. A influência da fonte de luz para fotoativar sistema sobre a presença de fendas pode ser confirmada pela análise estatística. As combinações LED/LED e QTH/LED apresentaram maiores porcentagens de fendas. Quando se utilizou PAC para o sistema adesivo, observaram-se os menores valores de fenda, independente da fonte de luz para a resina composta. As combinações PAC/PAC, PAC/QTH e PAC/LED apresentaram os menores valores de extensão de fendas. Da análise estatística, verificou-se que nos grupos em se utilizou o PAC para fotoativar o sistema adesivo, independente da fonte de luz utilizada para fotopolimerizar a resina composta encontraram-se valores significantemente menores quando comparados a LED/LED, que apresentou os maiores de extensão de fendas. As combinações que utilizaram o QTH para o sistema adesivo apresentaram valores mais homogêneos, independente da fonte de luz para a resina composta. 


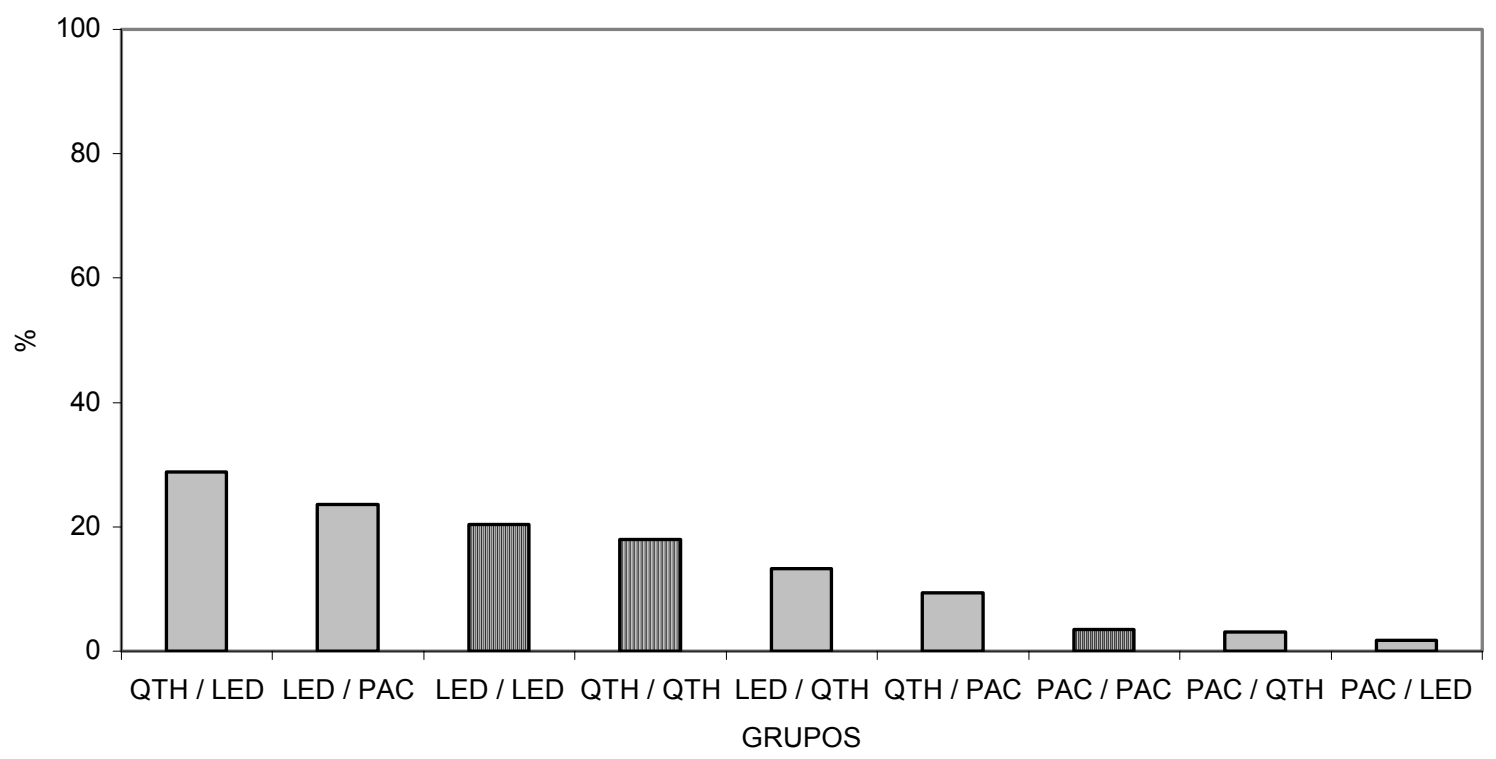

Figura 60 - Presença de fendas entre a camada de adesivo e a camada híbrida, independente da presença de corante verde (escores 4 e 5)

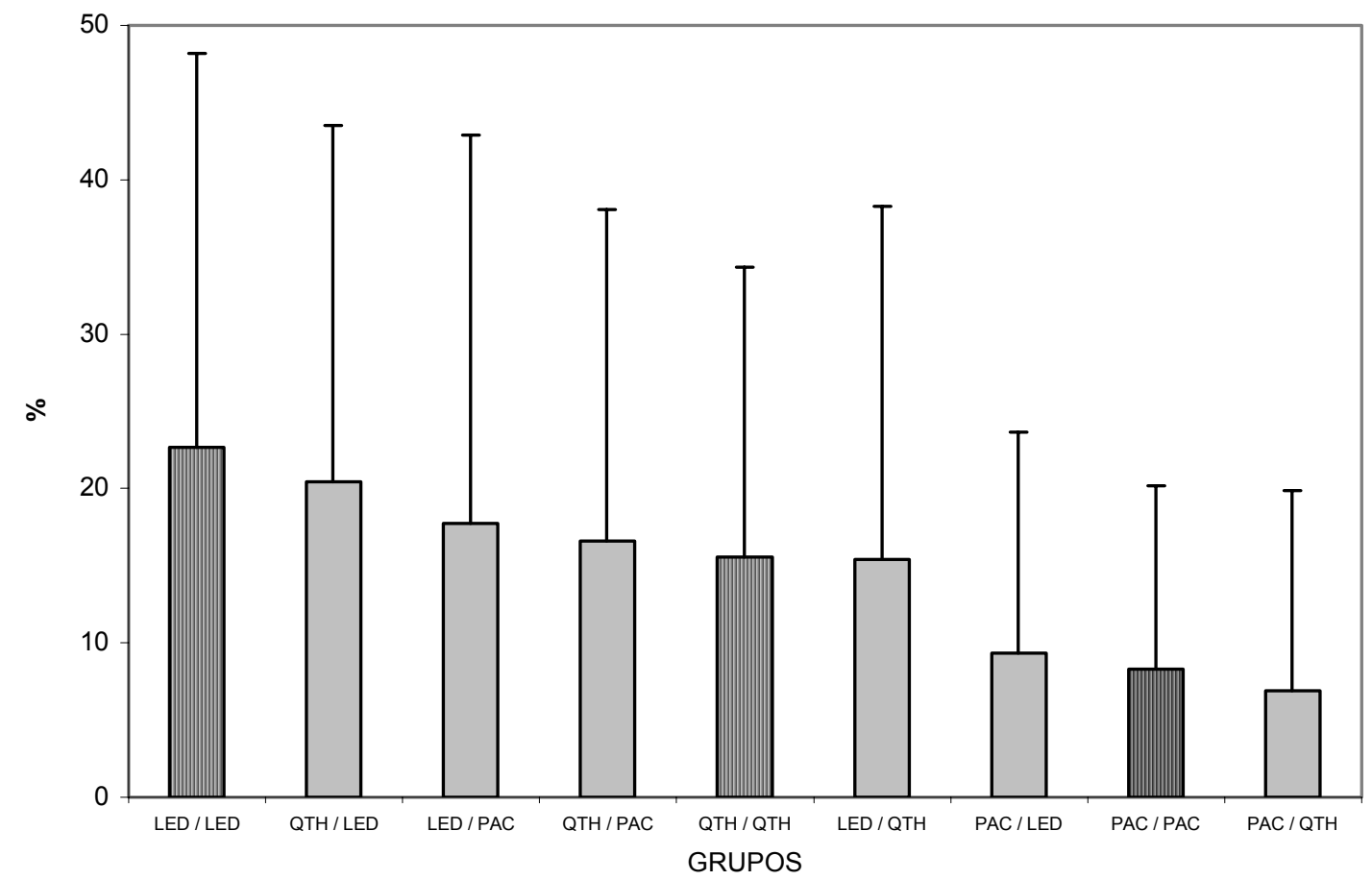

Barras verticais representam desvio-padrão

Figura 61 - Valores de porcentagem de extensão de fendas organizados em ordem decrescente 


\subsection{7- Resistência de União Adesiva}

Na Tabela 29, observam-se os valores de resistência adesiva, bem como os desvios-padrão, nos diferentes grupos experimentais avaliados. Realizou-se análise estatística dos valores médios obtidos nos diferentes espécimes (ANOVA dois critérios, $\alpha=0,05)$. A combinação LED/QTH apresentou valores significantemente menores que as combinações PAC/QTH $(p=0,0009)$ e QTH/QTH $(p=0,0360)$. Da mesma forma, a combinação LED/PAC apresentou valores significantemente menores que PAC/QTH, que apresentou os maiores valores de resistência adesiva em relação aos demais grupos experimentais.

Tabela 29 - Valores de resistência adesiva nos diferentes grupos experimentais

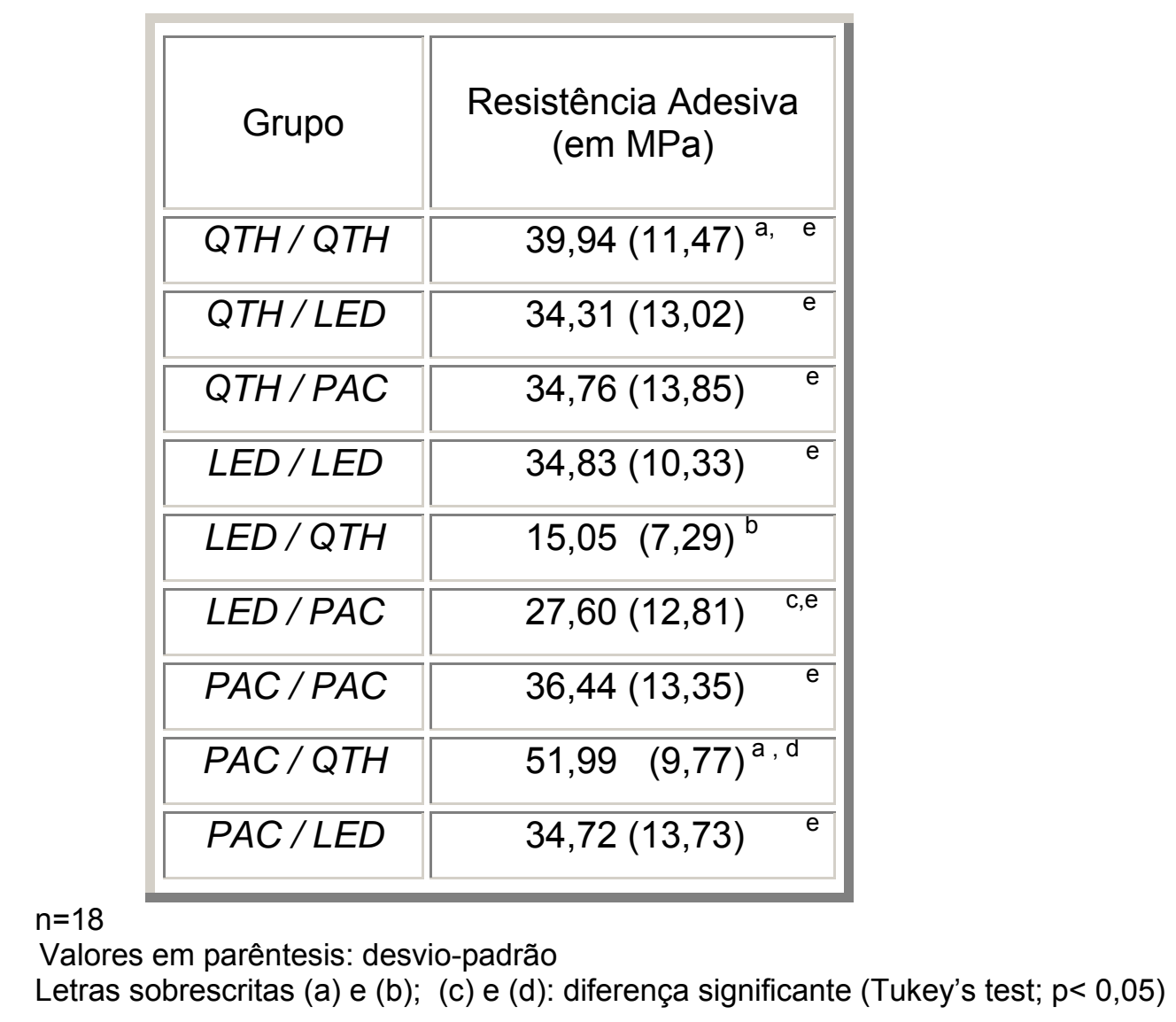

Na Figura 62, a seguir, estão os valores de resistência adesiva em ordem decrescente. Pode-se observar desta forma a influência das fontes de luz 
fotoativadora nos diferentes grupos experimentais. Pela análise dos resultados, pode-se verificar que a combinação PAC/QTH apresentou os maiores valores de resistência adesiva. Os menores valores foram apresentados pela combinação LED/QTH. As combinações QTH/QTH, LED/LED e PAC/PAC apresentaram valores médios semelhantes e estão destacados no gráfico. A Figura 63 mostra a relação dos valores de resistência adesiva de acordo com a fonte de luz fotoativadora aplicada separadamente, para o sistema adesivo e para a resina composta. Pode-se verificar claramente a influência das diferentes fontes de luz sobre os grupos experimentais. Quando se utilizou QTH para fotopolimerizar a resina composta nos diferentes grupos, houve grande variação nos valores de resistência adesiva. Neste gráfico verifica-se que houve valores homogêneos de resistência adesiva quando se utilizou LED para fotoativar a resina composta. Utilizando-se de QTH para fotoativar a resina composta, observaram-se valores mais heterogêneos. Da mesma forma, verifica-se que as combinações QTH/QTH, LED/LED e PAC/PAC apresentaram valores de resistência adesiva semelhantes.

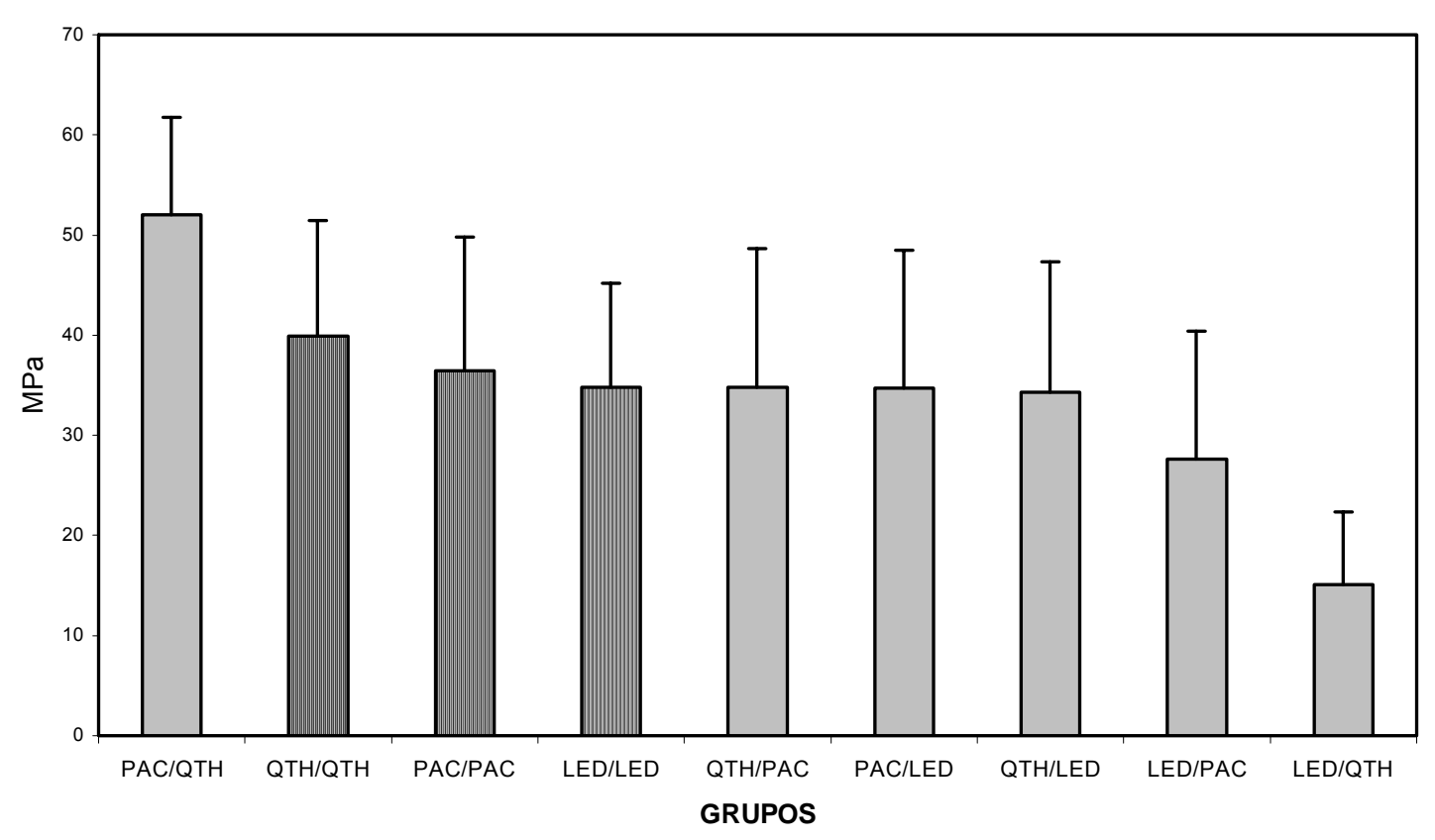

Barras verticais representam desvio-padrão

Figura 62 - Valores de resistência adesiva (MPa) em ordem decrescente 


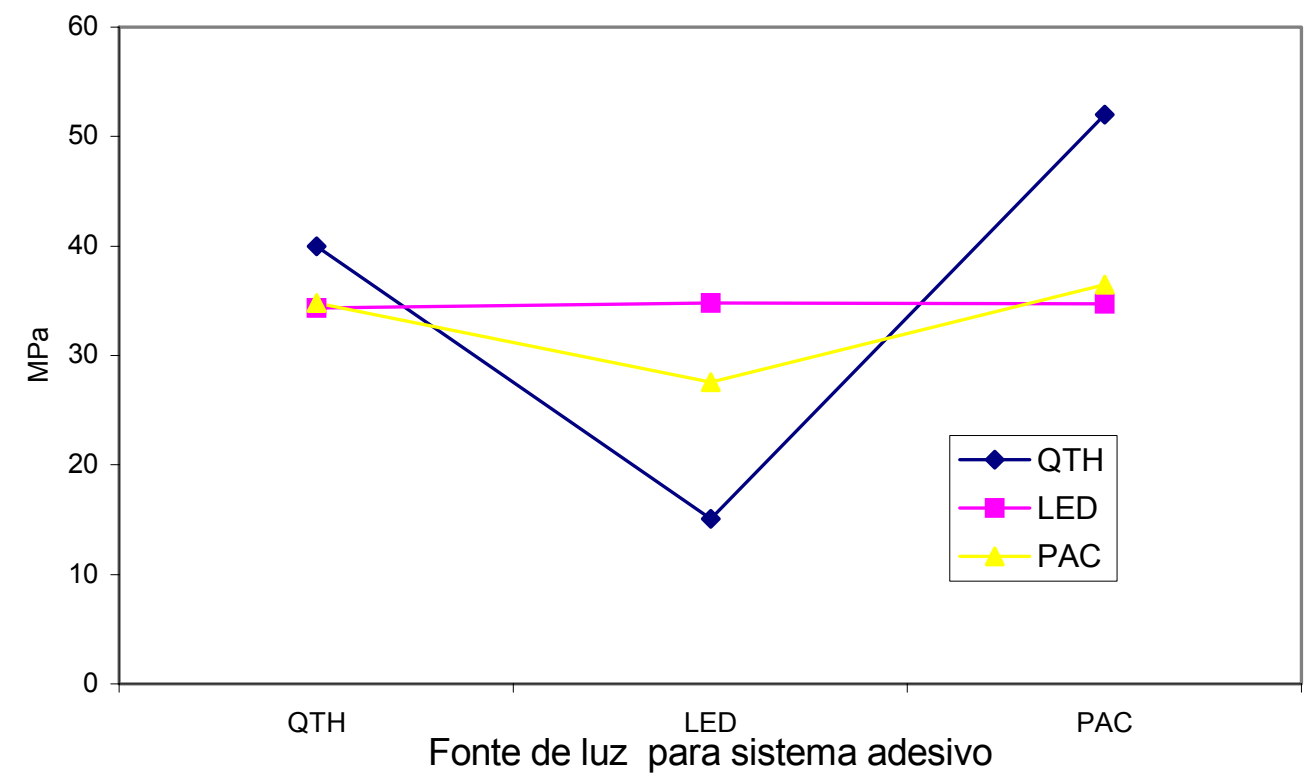

Legenda: fonte de luz fotoativadora para resina composta

Figura 63 - Valores de resistência adesiva de acordo com as diferentes combinações de fonte de luz fotoativadora

$\mathrm{Na}$ Tabela 30, a seguir, observa-se a influência das diferentes fontes de luz fotoativadora nos dois materiais de forma independente. Quando se analisou estatisticamente a influência da fonte de luz sobre o sistema adesivo, verificaram-se valores significantemente maiores de resistência adesiva quando fotoativado com PAC e com QTH, comparados a LED.

Tabela 30 - Influência da fonte de luz foativadora sobre os materiais restauradores utilizados

\begin{tabular}{|c|c|c|c|c|c|c|}
\hline \multirow{2}{*}{$\begin{array}{l}\text { Fonte } \\
\text { de Luz }\end{array}$} & \multicolumn{2}{|c|}{ QTH } & \multicolumn{2}{|c|}{ LED } & \multicolumn{2}{|c|}{ PAC } \\
\hline & $\begin{array}{l}\text { Sistema } \\
\text { Adesivo }\end{array}$ & $\begin{array}{l}\text { Resina } \\
\text { Composta }\end{array}$ & $\begin{array}{l}\text { Sistema } \\
\text { Adesivo }\end{array}$ & $\begin{array}{l}\text { Resina } \\
\text { Composta }\end{array}$ & $\begin{array}{l}\text { Sistema } \\
\text { Adesivo }\end{array}$ & $\begin{array}{l}\text { Resina } \\
\text { Composta }\end{array}$ \\
\hline QTH & & & $0,0398^{*}$ & 0,9619 & & \\
\hline LED & & & & & $0,0028^{*}$ & 0,9059 \\
\hline PAC & 0,4870 & 0,7744 & & & & \\
\hline
\end{tabular}

${ }^{*}$ significante $(p<0,05)$ 
Quando se analisou a influência da fonte de luz fotoativadora sobre a resina composta, não se encontrou diferença significante entre os valores de resistência adesiva. Pode-se verificar que utilizando diferentes aparelhos de luz produziram-se diferentes valores de resistência adesiva e que estes valores foram mais influenciados pela fonte de luz que fotoativa o sistema adesivo do que a que fotoativa a resina composta. Quando se utilizou LED para fotoativar o sistema adesivo, a resistência adesiva foi significantemente menor em comparação aos valores de QTH e PAC.

$\mathrm{Na}$ análise fractográfica, as interfaces fraturadas foram analisadas em ambos os lados, dentina e resina. Todos os espécimes avaliados revelaram modo de fratura do tipo misto, ou seja, com áreas de fratura adesiva e coesiva. No entanto, apenas por alguns aspectos observados durante a análise, foram anotadas algumas características. Na maioria dos casos havia a correspondência no formato das superfícies fraturadas que eram complementares. A combinação LED/QTH apresentou maiores ocorrências de presença fratura de corpo de resina composta no lado "dentina". 
6- Discussão 


\section{6- Discussão}

\section{1- Cinética da Conversão de Monômeros}

Os aparelhos fotoativadores selecionados no presente estudo representaram uma variedade das classificações mais comumente utilizadas. $O$ aparelho fotoativador com lâmpada halógena (QTH) apresentou um espectro de irradiância relativamente amplo, com uma moderada densidade de potência. Com o auxílio de filtros, o espectro de luz é emitido somente no comprimento de onda azul. Este aparelho ainda é, atualmente, um dos mais utilizados nos consultórios odontológicos e se caracteriza por apresentar uma diminuição na densidade de potência ao longo do tempo de vida útil da lâmpada. O aparelho com diodo emissor de luz azul (LED) forneceu uma alta densidade de potência dentro de uma estreita faixa do espectro de luz visível, em uma região sabidamente coincidente com a absorbância da canforoquinona. O LED utilizado no presente estudo constitui-se da segunda geração deste tipo de aparelho, caracterizando-se por apresentar uma maior densidade de potência em relação aos aparelhos da primeira geração e por conter, na maioria das vezes, um único diodo emissor de luz. O específico aparelho utilizado no presente estudo apresenta ainda diferentes tempos de exposição (5, 10, 15 e 20 segundos) e caracteriza-se por não apresentar cabo elétrico unindo-se à base. 0 aparelho arco de plasma (PAC) representou uma fonte de luz fotoativadora com altíssima densidade de potência e com um amplo espectro (Figura 2).

Todos estes aparelhos foram utilizados para polimerizar o sistema adesivo e a resina composta para análise da cinética de conversão através de um espectrofotômetro de raios infravermelhos. Este tipo de espectrofotômetro tem sido amplamente utilizado para avaliação da conversão de monômeros ${ }^{141}$. O sistema adesivo foi aplicado sobre o ATR do FT-IR seguindo as especificações do fabricante. Mesmo utilizando uma fita adesiva para evitar o espalhamento do sistema adesivo e padronizar a espessura do filme que era, então, polimerizado, fez-se necessária a aplicação de uma matriz de poliéster sobre o mesmo. A utilização desta matriz sobre o filme de adesivo não representa o que ocorre clinicamente e poderia alterar a cinética da conversão, favorecendo o aumento da conversão total de monômeros 
pela ausência da camada inibidora de oxigênio. Testes piloto comparando os diferentes parâmetros de conversão, com e sem a aplicação da matriz de poliéster, revelaram que não houve influência da mesma nos resultados obtidos. Além disso, a matriz favoreceu a homogeneização da espessura do filme de adesivo que se formou.

Quanto à avaliação da resina composta em espectrofotômetro, embora o volume de material tenha sido diferente do volume aplicado nos preparos cavitários, a conversão que ocorreu na base do espécime deve ter correspondido à ocorrida na base da restauração. Neste caso, o mais importante foi a padronização da espessura de resina composta, igual à aplicada aos preparos cavitários. A análise dos resultados da cinética da conversão de monômeros, tanto no sistema adesivo quanto na resina composta, mostrou que houve influência das diferentes fontes de luz fotoativadoras nos diferentes parâmetros analisados. Não somente as diferenças na densidade de potência, mas também os espectros de irradiância, foram fatores que influenciaram nos resultados, principalmente em termos de conversão total de monômeros, na taxa máxima de conversão, bem como no tempo em que ocorreu esta máxima taxa. Estudos têm sugerido que a profundidade de polimerização é influenciada por fatores relacionados à resina composta e à fonte fotoativadora ${ }^{38,183}$. Os fatores relacionados à resina composta incluem a cor, translucência, tamanho, quantidade e distribuição das partículas inorgânicas. Os fatores relacionados aos aparelhos fotoativadores são a intensidade de luz, o espectro de irradiância e o tempo de exposição ${ }^{195}$. Desta forma, os aparelhos fotoativadores devem fornecer uma quantidade de fótons suficiente para que ocorra uma polimerização adequada da resina composta, além de possibilitarem melhores propriedades mecânicas ${ }^{48}$.

Diferentes tempos de exposição foram utilizados para polimerizar a resina composta no presente estudo, baseado em informações do fabricante. Assim, já que diferentes aparelhos fotoativadores apresentaram diferentes densidades de potência, conseqüentemente diferentes densidades de energia também foram utilizadas. O aparelho PAC apresentou claramente a maior densidade de potência com um amplo espectro de irradiância (Figura 2). De acordo com um recente estudo, um tempo de exposição de 10 segundos com este aparelho proporcionou propriedades mecânicas semelhantes àquelas conseguidas com tempo de 
polimerização de 20 segundos com aparelhos $\mathrm{QTH}^{121}$. Fotoativando-se a resina composta com o aparelho PAC, ocorre uma polimerização rápida, sendo que o risco do desenvolvimento de tensões na interface interna e marginal não pode ser completamente ignorado.

O aparelho LED de segunda geração, utilizado no presente estudo, apresentou uma alta densidade de potência com um espectro de irradiância estreito. Segundo alguns relatos, resinas compostas fotoativadas com luz azul emitida por diodos emissores de luz, apresentam maior grau de conversão, estrutura polimérica tridimensional mais estável e, ainda, maior profundidade de polimerização em comparação aos tradicionais aparelhos com lâmpada halógena ${ }^{96,102}$. Apesar do aparelho LED utilizado neste estudo apresentar a menor densidade de energia quando se polimerizou a resina Filtek Z250, a porcentagem de conversão de monômeros foi similar à conseguida com QTH (45,5 \% e 44,7 \%). Já o PAC promoveu a maior porcentagem de conversão de monômeros $(49,2 \%)$ para a resina composta.

O aparelho QTH utilizado no presente estudo apresentou espectro de irradiância mais amplo comparado ao LED, porém menor densidade de potência (Tabela 2). Quando o QTH foi utilizado para o sistema adesivo, a menor densidade de energia e de potência foram empregadas, comparado às demais fontes de luz. Porém, a porcentagem de conversão de monômeros foi significantemente maior (98,1 \%), em comparação ao LED e PAC (93,8 \% e 92,2 \%, respectivamente). Na Tabela 5 vêem-se claramente as diferenças da influência da densidade de potência sobre a conversão nos dois materiais avaliados. A Figura 49 mostra que houve uma relação inversa entre a densidade de potência e a conversão de monômeros no sistema adesivo utilizado. Em outras palavras, quanto maior a densidade de potência, menor a conversão de monômeros, provando que houve uma diferença na efetividade de polimerização do material entre os aparelhos utilizados.

Alguns fatores foram propostos para explicar estas diferenças. Durante a polimerização rápida com PAC, as duplas ligações de carbono não reagidas, localizados nos grupos funcionais, são rapidamente aprisionados dentro das cadeias poliméricas que são formadas, devido a um rápido aumento da viscosidade na fina espessura do filme de sistema adesivo ${ }^{8}$. Quando se polimerizou o sistema adesivo 
com QTH, houve, possivelmente, a formação de um maior número de cadeias de polímeros, com o aumento da conversão de monômeros. Considerando-se o fato de que a eficiência de polimerização do aparelho é proporcional ao grau de conversão, ficou demonstrado que a efetividade do PAC de polimerizar sistemas adesivos foi menor que o LED e QTH.

Em um recente estudo ${ }^{8}$, encontrou-se uma forte correlação entre o grau de conversão e a contração de polimerização quando adesivos ortodônticos foram polimerizados com QTH. Estes mesmos autores encontraram uma pobre correlação do grau de conversão com a contração de polimerização quando o PAC foi utilizado. Estes resultados indicam que o PAC para fotoativar o sistema adesivo poderia produzir uma menor tensão de contração em comparação com o QTH, por promover menor conversão de monômeros. Os resultados do presente estudo foram corroborados já que o PAC produziu significantemente menor porcentagem de conversão total quando comparado à porcentagem apresentada pelo QTH para polimerizar o mesmo material. Em um outro estudo ${ }^{194}$, os autores compararam a cinética de conversão de diferentes sistemas adesivos que foram fotoativados com QTH e LED de terceira geração (UltraLume5) e concluíram que o LED é melhor que o QTH em termos de taxa de polimerização e grau de conversão para o sistema adesivo, cujo fotoiniciador apresenta uma absorbância em um comprimento de onda diferente da canforoquinona. Por outro lado, a polimerização dos sistemas adesivos que contêm este fotoiniciador ocorreu em função do tempo de exposição, independente da fonte de luz ou intensidades empregadas. Os autores concluíram que a eficiência da polimerização dos adesivos comerciais pode variar em função da fonte de luz.

A diferença entre a porcentagem de conversão de monômeros do sistema adesivo e da resina composta deve-se ao fato de que o primeiro se apresenta em estado líquido e, mesmo nos estágios iniciais de polimerização, há flexibilidade e certa fluidez. Por outro lado, a resina composta apresenta maior viscosidade, além de conter partículas inorgânicas, que são impeditivos para que haja uma maior porcentagem de conversão ${ }^{137}$. Além disso, a formulação da resina contém diferentes monômeros, o que lhes conferem diferentes habilidades de formação de cadeias poliméricas. $\mathrm{O}$ adesivo Adper Single Bond contém HEMA e BisGMA, enquanto que a 
resina Filtek Z250 contém uma mistura de UDMA, BisEMA e TEGDMA. Estes monômeros, certamente, apresentam diferença no grau de conversão devido às diferenças em suas respectivas composições químicas e peso moleculares ${ }^{118}$.

Outra questão é a baixa porcentagem de conversão de monômeros da resina Filtek Z250. A literatura relata porcentagens em torno de 60 a $70 \%$ nas resinas atualmente existentes no mercado ${ }^{143}$. No presente estudo, as porcentagens encontradas se devem, possivelmente, por se tratar da avaliação da conversão que ocorreu na base de um incremento único de resina composta. Na superfície da resina composta há um mínimo de atenuação de luz e o processo de polimerização se procede rapidamente pois, "virtualmente", toda canforoquinona presente pode ser levada a um estado energético que favorece o desencadeamento da reação ${ }^{139}$. Dependendo da densidade de potência, maior número de fótons será capaz de penetrar mais profundamente, aumentando a probabilidade de haver maior número de moléculas "fóton-absorvedoras" em estado excitado propício para reação ${ }^{137}$. Na base da resina, a conversão de monômeros pode ser minimizada por diferentes fatores como espessura do incremento, cor da resina, e ainda pelo efeito do espalhamento da luz promovido pelas partículas inorgânicas, reduzindo a porcentagem de conversão total. Uma reduzida conversão de monômeros pode levar à ocorrência de propriedades mecânicas inferiores nas resinas compostas. Parece haver uma boa correlação entre grau de conversão de monômeros com o grau de dureza, tenacidade de fratura e resistência ao desgaste ${ }^{12,52}$.

Comparando-se a taxa máxima de conversão quando se polimerizaram ambos materiais restauradores com os diferentes aparelhos fotoativadores, houve uma correlação positiva entre este parâmetro e a densidade de potência $\left(R^{2}=\right.$ 0,9559 para resina composta - Anexo 4). Assim, utilizando-se PAC para polimerizar sistema adesivo e resina composta, menor foi o tempo em que ocorreu a máxima taxa de conversão (Tabela 7). Conforme há formação do polímero, a taxa de conversão torna-se limitada, desacelerando-se após a taxa máxima, geralmente na presença de uma conversão mais reduzida, resultando, então, em monômeros não reagidos e alguns radicais livres. Com uma densidade de potência menor, houve menor taxa de conversão total e a máxima taxa ocorreu mais tardiamente. Em termos de conversão de monômeros na taxa máxima de conversão, não houve 
diferença para ambos os materiais restauradores quando fotoativados com as diferentes fontes de luz (Tabela 8).

Uma interessante relação conversão na máxima taxa / conversão total foi obtida quando diferentes fontes de luz foram utilizadas. Quando o LED foi utilizado para ambos os materiais, a porcentagem de conversão de monômeros que ocorreu na máxima taxa foi proporcionalmente maior em relação à conversão total (Figura 50). Observou-se, especialmente para o sistema adesivo, que o PAC produziu a menor razão entre porcentagem de conversão na máxima taxa e conversão total. Baseado nestes resultados pode-se sugerir que um rápido aumento na viscosidade do Adper Single Bond, quando se utilizou PAC, promoveu a menor conversão de monômeros na máxima taxa. A máxima intensidade produzida por esta fonte de luz polimerizadora também promoveu um rápido aumento na viscosidade da resina composta, comprometendo sensivelmente o seu escoamento. Para esse material, a conversão na máxima taxa em relação à conversão total produziu resultados similares quando o PAC e QTH foram comparados $(24,2 \%$ e $25,3 \%$ respectivamente). O LED revelou maior porcentagem $(28,3 \%)$ quando esta relação foi calculada.

Uma possível explicação, pelo fato do LED apresentar maiores valores para esta relação, se deve ao fato de que, aliado à alta densidade de potência, o espectro de irradiância deste aparelho é coincidente com a absorbância da canforoquinona. Isto possibilitou as maiores porcentagens de conversão de monômeros na máxima taxa de conversão em ambos os materiais. Os problemas clínicos relacionados à alta conversão de monômeros estão relacionados à contração de polimerização, especialmente quando a máxima taxa de conversão ocorre em um curto espaço de tempo. Neste caso, o pior resultado seria proporcionado pelo LED. A contração que acompanha a polimerização das resinas compostas gera uma resultante de forças na interface dente/restauração, que leva à formação de fendas marginais, principalmente quando se atinge rapidamente o ponto gel ${ }^{18}$. Em termos de sistema adesivo, a contração de polimerização poderia prejudicar a função dos tags de resina. $O$ desempenho dos tags de resina seria alcançado se estivessem firmemente aderidos às paredes dos túbulos dentinários ${ }^{107}$, fundamental para o desenvolvimento de uma resistência adesiva mais forte ${ }^{22}$. 
A cinética da conversão é de interesse e de extrema importância, pois pode indiretamente refletir nas propriedades mecânicas e na longevidade das restaurações adesivas ${ }^{43}$. As propriedades mecânicas dos sistemas adesivos após a polimerização devem indiretamente refletir na qualidade da interface adesiva obtida. Geralmente os sistemas adesivos têm melhores propriedades mecânicas quando são suficientemente polimerizados ${ }^{91}$. Uma vez que os materiais resinosos podem sofrer contração de polimerização, tanto a densidade de potência dos aparelhos fotoativadores, quanto o espectro de irradiância, têm influência na cinética de conversão e sobre as propriedades mecânicas iniciais. Estas propriedades podem promover melhor resistência adesiva e um melhor selamento marginal. $O$ conhecimento das propriedades mecânicas iniciais dos sistemas adesivos fornece informações relevantes para interpretação da dissipação das tensões geradas na interface adesiva logo após a realização de restaurações ${ }^{161}$.

Os aparelhos de luz fotoativadoras produziram resultados diferentes em parte dos parâmetros da cinética de conversão analisados, tanto para a resina composta como para o sistema adesivo. Desta forma, a primeira hipótese nula deve ser rejeitada.

\section{2- Análise da micromorfologia da interface adesiva}

Os corantes fluorescentes têm sido utilizados em microscopia ótica como uma ferramenta para melhorar a qualidade de visualização de um espécime com certa resolução e contraste. Quando um determinado corante é adicionado e fixado a um substrato específico, uma característica emissão de fluorescência indica a sua presença, destacando-se assim o material ou o tecido a que está aderido ou unido. Utilizando-se a metodologia para avaliação da micromorfologia da interface adesiva, possibilitou-se uma avaliação mais precisa dos espécimes, por não haver a necessidade de preparações mais elaboradas dos mesmos, evitando-se problemas como desidratação, entre outros ${ }^{189}$. O potencial selamento da camada híbrida tem sido avaliado pela aplicação de corantes fluorescentes na câmara pulpar, no chamado "teste de micropermeabilidade" ${ }^{\text {"2, } 153}$. Neste teste, o corante se difunde em meio aquoso no interior dos túbulos dentinários em direção aos tags de resina e à 
camada híbrida. A penetração de corante através destas "barreiras" refletem a habilidade de selamento do sistema adesivo utilizado ${ }^{62}$.

Rodamina B é o corante mais extensivamente utilizado em microscopia de fluorescência ${ }^{26}$. Este corante é facilmente detectado, mesmo quando utilizado em microscopia ótica convencional com menor magnitude, exibindo uma característica cor vermelho intenso. As características deste corante, bem como de outros comumente utilizados em microscopia ótica e de fluorescência, estão listadas no Anexo 6. Para microscopia de fluorescência, este corante pode ser utilizado em pequenas concentrações devido a seu alto coeficiente de extinção molar $^{188}$, o que significa que a molécula tem uma alta absorbância de fótons no ideal comprimento de onda de absorção, emitindo, assim, muitos fótons fluorescentes quando no estado excitado. Apesar dos corantes fluorescentes serem inertes e prontamente solúveis em componentes orgânicos como primers, adesivos dentinários e selantes de superfície ${ }^{128}$, eles têm sido adicionados somente de forma empírica a estes materiais $^{26}$. Dependendo da concentração, essas substâncias podem reduzir a porcentagem de conversão de monômeros, bem como a resistência de união das restaurações adesivas.

Devido ao fato desses corantes absorverem luz, eles também podem inibir a quantidade de fótons que atinge os fotoiniciadores e, assim, reduzir a possível formação de polímeros e a resistência mecânica do sistema adesivo. O pior cenário ocorreria se houvesse uma alta concentração de corante. A concentração dessas substâncias nos sistemas adesivos é bastante crítica, dependendo do material resinoso, devido ao fato de poder levar a uma incorreta informação do desempenho clínico dos materiais restauradores adesivos. A maioria dos estudos não menciona a exata concentração dos corantes adicionados aos componentes dos sistemas adesivos. Até agora não há nenhum estudo que avaliou a influência destes corantes na cinética da conversão de monômeros, nem na resistência de união das restaurações adesivas a seus substratos. A influência dos corantes fluorescentes no $\mathrm{pH}$ dos sistemas adesivos também é um aspecto a ser considerado. Sabe-se que as soluções aquosas e alcoólicas contendo Rodamina B apresentam um pH acídico ${ }^{35}$ e a adição de diferentes concentrações deste específico corante a certos materiais resinosos poderia causar alteração de seu $\mathrm{pH}$ original. Tornou-se, então, 
extremamente importante a avaliação da concentração final e o pH do corante fluorescente que foi adicionado ao sistema adesivo Adper Single Bond. Isto poque a eventual redução do $\mathrm{pH}$ original do sistema adesivo poderia alterar o substrato dentinário ao qual é aplicado, levando a um provável sobre-condicionamento (overetching).

As técnicas de microscopia de fluorescência são particularmente importantes devido às informações que se obtém do espécime em questão e também pela sua rápida evolução e desenvolvimento ${ }^{40}$. Com o advento de novas técnicas de microscopia de fluorescência, de novos corantes fluorescentes, juntamente com a disponibilidade de novos lasers, possibilitou-se a obtenção de resultados mais confiáveis. A técnica de Laser de Dois Fótons (Two-Photon laser) é uma forma nova de microscopia de fluorescência por utilizar um laser que emite um comprimento de onda de excitação além da região de luz vermelha no espectro de luz visível (far redfield). Este laser promove a emissão de um comprimento de onda excitadora para um ou mais corantes fluorescentes ao mesmo tempo, diferentemente do microscópio confocal que utiliza dois lasers para ativar dois ou mais corantes de forma independente. Esta técnica possibilitou inúmeras vantagens sobre as técnicas convencionais de microscopia de fluorescência para o estudo tridimensional de estruturas biológicas diversas, bem como a avaliação dinâmica da função de órgãos e estruturas ${ }^{37,39}$ com alta sensibilidade de detecção.

Basicamente, as estruturas do Laser de Fóton Duplo são as mesmas do confocal convencional, mas com a importante substituição dos lasers comumente utilizados por uma fonte emissora de titânio/safira. As principais vantagens da utilização do Two-Photon laser são a possibilidade da utilização do comprimento de onda infravermelho ou, além da região de luz vermelha (far red-field), a redução da dispersão da fluorescência (scattering) e a maior penetração no espécime. A resolução do microscópio quando ajustado ao laser de titânio/safira não se equivale à resolução do confocal convencional devido ao fato de utilizar um comprimento de onda excitadora em baixa freqüência ${ }^{65}$.

$\mathrm{Na}$ prática, é difícil se obter uma resolução ideal quando se analisam os espécimes em microscopia. A melhor forma de se aumentar a resolução é através da otimização do comprimento de onda e da abertura numérica da lente objetiva 
utilizada, além da remoção do pinhole comumente utilizado em confocal convencional. Esta ferramenta reduz o plano focal, evitando a captação de fluorescência que ocorre por dispersão, principalmente aquela advinda de fora do plano focal. No laser de dois fótons, como o plano focal é reduzido, não há necessidade da utilização desta ferramenta. Toda fluorescência emitida pelos espécimes analisados pode ser captada, melhorando-se, assim, a qualidade da imagem. Outra importante vantagem é a atenuação da potência do laser que, quando muito elevada, reduz o risco de alteração ou destruição do tecido analisado (photodamage $)^{129}$. Além disso, como não há fluorescência em áreas fora do plano focal, toda a luz emitida é coletada pelo microscópio e, então, utilizada para a construção da imagem. Com isso, há uma redução na razão sinal/ruído (signal-tonoise ratio) apresentada pela imagem, promovendo, assim, melhor resolução. $O$ aumento da proporção sinal/ruído se deve a uma possível fluorescência do background, de outras áreas do espécime ou, ainda, da auto-fluorescência dos componentes óticos.

A maioria dos estudos morfológicos têm utilizado MEV para avaliar camada híbrida e estruturas vizinhas ${ }^{163}$. No entanto, há a possibilidade de artefatos de técnica quando da obtenção dos espécimes, uma vez que nas fibrilas de colágeno, bem como na estrutura do polímero que forma a camada híbrida, deve haver água residual $^{79}$. A técnica de microscopia confocal representa uma evolução em relação às técnicas que utilizam MEV, por não requer os inúmeros passos operatórios, reduzindo a ocorrência de artefatos ou de contração do tecido avaliado, já que não exige a desidratação do espécime.

Críticas têm sido publicadas em relação à possibilidade de liberação (leaching) do corante fluorescente contido na camada híbrida ou nos tags de resina, já que se espera a que o corante fique restrito a estas estruturas. Depois de polimerizado o sistema adesivo, não há ligação covalente entre os corantes e o polímero formado, sendo então aprisionados na rede polimérica que se forma após a fotoativação ${ }^{150}$. A preocupação em relação à liberação (leaching) dos corantes fluorescentes dos sistemas adesivos polimerizados se deve ao fato de poder interferir na análise microscópica das imagens, possivelmente indicando a distribuição do corante em regiões diferentes daquelas impregnadas pelos 
componentes do sistema adesivo utilizado $^{189}$. Entretanto, a extensão com que há liberação do corante fluorescente dos sistemas adesivos polimerizados necessita, ainda, ser avaliada. Se a liberação for substancial, deve resultar na falsa indicação da presença do adesivo. Por outro lado, alguns autores ${ }^{125,128,190}$ afirmaram que a penetração e permeação do corante no substrato dentinário úmido não representam uma preocupação, porque a liberação do corante deve acontecer somente na extremidade dos tags de resina que não foram polimerizados pela falta de acessibilidade da luz fotoativadora ou devido à diluição no interior dos túbulos dentinários. Desta forma, a liberação do corante fluorescente não deve interferir na avaliação das imagens da interface adesiva por microscopia confocal ${ }^{123,124}$. A presença de monômeros não polimerizados ou oligômeros pode ser facilmente detectada nas imagens de microscopia confocal, bem com nas imagens analisadas em MEV, principalmente se não houver pressão pulpar.

Outro problema ao se adicionar um corante fluorescente aos sistemas adesivos é o quanto ele se dissolve nos monômeros resinosos e nos solventes, já que o mecanismo de manutenção e estabilidade do mesmo no polímero formado está baseado somente em um simples processo de mistura, ao invés da formação de ligações covalentes entre as moléculas do corante com os monômeros resinosos $^{150}$. Desta forma, é importante verificar se o corante é solúvel no material resinoso ao qual está sendo adicionado. Dependendo da distribuição do corante por todo o solvente, mais confiáveis são os resultados. Entretanto, o risco de uma distribuição não homogênea não pode ser excluído. Por outro lado, sabe-se que a Rodamina B é extremamente solúvel em solventes orgânicos como primer e $\operatorname{adesivos}^{128}$, mas a solução deve ser preparada antecipadamente devido ao longo tempo que os componentes resinosos levam para dissolver o corante.

Além disso, estudos preliminares utilizando espectrofotômetro de luz visível mostraram que houve mínima liberação de Rodamina B dos espécimes de sistema adesivo fotoativados, em forma de discos de $170 \mu \mathrm{m}$ de espessura, quando os mesmos foram imersos em água destilada bem como em óleo vegetal, por um período de até uma semana. Por outro lado, quando imersos em etanol, os espécimes mostraram liberação de monômeros residuais e da massa original de Rodamina B em torno de 50 \%. Estas foram as razões pelas quais os dentes foram 
seccionados em uma máquina de cortes refrigerada com óleo vegetal, bem como o armazenamento dos espécimes em água destilada após os procedimentos restauradores.

Tomou-se, ainda, o cuidado com a preservação da integridade dos substratos e manutenção do $\mathrm{pH}$ do meio. A solução contendo corante fluorescente verde (Dextran-Fluoresceína), que foi aplicada na câmara pulpar, foi preparada com PBS cujo $\mathrm{pH}$ é neutro. Desta forma, evitou-se que houvesse qualquer influência da solução sobre a camada híbrida e sobre os tags de resina, no sentido de promover remoção (leaching) de monômeros residuais e de Rodamina B destas estruturas. Observou-se, também, que não houve alteração do $\mathrm{pH}$ do adesivo dentinário $(\mathrm{pH}=$ $4,3)$ quando se adicionou este corante. Ainda, como controle piloto, foram realizados testes de resistência adesiva em restaurações de resina composta cujo adesivo continha Rodamina B. Os resultados de resistência adesiva foram comparados aos obtidos nos espécimes sem corante. A concentração do corante adicionado foi a mesma utilizada para avaliação da cinética da conversão $(0,16 \mathrm{mg} / \mathrm{ml})$. O sistema adesivo foi aplicado à superfície dentinária plana de terceiros molares que tiveram o esmalte removido. O teste propriamente dito, bem como a obtenção dos resultados, seguiram o protocolo descrito no tópico 3.7. Verificou-se que não houve diferença nos valores de resistência de união adesiva com ou sem a adição do corante. Os valores apresentados foram por volta de $72 \mathrm{MPa}$.

Estudos piloto mostraram, ainda, que a utilização de solução aquosa de Fluoresceína Sódica convencional fornecia resultados não confiáveis, uma vez que não se apresentava de forma homogênea no interior dos túbulos e se disseminava erroneamente por toda a estrutura dentária. Utilizou-se uma solução aquosa de Fluoresceína conjugada com polissacarídeo por possibilitar a movimentação do corante no interior dos túbulos em direção à interface adesiva. Estudos preliminares com espectrofotômetro de luz visível ${ }^{\text {gg }}$ demonstraram que a utilização de soluções alcoólicas de Fluoresceína promoveu a remoção de monômeros residuais, bem como a liberação (leaching) de Rodamina B dos espécimes de adesivo polimerizados, quando imersos em etanol.

\footnotetext{
gg UV-Vis spectrophotometer, model CHEM2000-UV-VIS Ocean Optics, Inc., Dunedin, FL, Estados Unidos
} 
Com relação aos parâmetros quantitativos da micromorfologia da interface adesiva, observou-se que houve influência das diferentes combinações de fonte de luz na espessura da camada de adesivo. A combinação PAC/QTH apresentou a camada de adesivo significantemente mais espessa, em comparação às combinações QTH/QTH, QTH/LED e LED/LED (Tabela 10). A análise dos dados revelou, ainda, que a espessura da camada de adesivo foi mais influenciada pela fonte de luz que polimeriza o sistema adesivo comparada à que polimeriza a resina composta. A utilização do PAC para o sistema adesivo promoveu camadas de adesivo significantemente mais espessas (entre 8,97 a 11,91 $\mu \mathrm{m}$ ), independente da fonte de luz que fotoativou a resina composta. As razões que explicam a ocorrência de camadas de adesivo mais espessas, quando se utilizou este específico aparelho fotoativador, parecem estar relacionados com os parâmetros de cinética de conversão. Baseado nestes resultados, a conversão de monômeros no sistema adesivo foi significantemente menor quando se utilizou o PAC para polimerizar o sistema adesivo, em comparação ao QTH. A alta intensidade de luz, com amplo espectro de irradiância, deve ter promovido uma polimerização instantânea do sistema adesivo, impedindo a movimentação dos monômeros na fina camada de adesivo que estava sendo polimerizada. Isto pode, ainda, explicar porquê a combinação QTH/QTH apresentou uma camada de adesivo mais fina $(5,07 \mu \mathrm{m})$. Tem-se relatado que a camada de adesivo auxilia na redução das tensões na base de restaurações adesivas ${ }^{7}$. Em teoria, quanto mais espessa essa camada, maior o efeito elástico para absorção das tensões. As tensões seriam então transformadas em deformação elástica da camada de adesivo.

Com relação às variações na espessura da camada híbrida, relatou-se haver pouca influência da mesma sobre a resistência de união adesiva ${ }^{66}$. O grau de impregnação dos monômeros resinosos por toda a dentina desmineralizada, bem como a área de contato na base desta superfície, parecem ser os fatores mais relacionados com a resistência adesiva ${ }^{114}$. No presente trabalho, a espessura da camada híbrida variou de 3,66 $\mu \mathrm{m}$ a 4,70 $\mu \mathrm{m}$ (Tabela 12), sendo relativamente similar aos resultados obtidos em outros estudos que utilizaram MEV ${ }^{115,135}$. A análise estatística revelou que não houve diferença significante entre as combinações avaliadas. Mesmo assim, a camada híbrida apresentou-se nítida nas 
imagens avaliadas e forneceu informações importantes em termos de homogeneidade e espessura, fundamentais para a confiabilidade da técnica de microscopia utilizada.

Independente da espessura da camada híbrida que é formada, o mais importante é a qualidade da mesma ${ }^{131}$. Com relação a este parâmetro, apesar de não haver diferença estatística entre os grupos experimentais (Tabela 14), verificouse que, quando o aparelho QTH foi utilizado para polimerizar o sistema adesivo, a porcentagem de baixa qualidade de camada híbrida foi menor (Tabela 16). As combinações que utilizaram LED para polimerizar o sistema adesivo apresentaram as maiores porcentagens de baixa qualidade, especialmente com as combinações LED/QTH e LED/PAC. Quando se utilizou o PAC para este mesmo material observaram-se as mais altas porcentagens de escore 1, sendo que a combinação PAC/PAC apresentou o maior valor (57,7\%). Ao mesmo tempo, o PAC produziu porcentagem alta de piores escores (escore 3). Considerando-se a somatória dos escores 1 e 2 para qualidade de camada híbrida, verificou-se que, de forma geral, as combinações que utilizaram QTH para o sistema adesivo apresentaram as maiores porcentagens de melhores escores (83,6 \%; 94,6 \% e 93,6 \%). Por outro lado, a análise estatística revelou, ainda, que não houve influência da fonte de luz fotoativadora utilizada para o sistema adesivo ou para a resina composta sobre a espessura ou qualidade da camada híbrida (Tabelas 13 e 15).

Quanto à micropermeabilidade, também não houve diferença significante quando se compararam os grupos experimentais (Tabela 17). Desta forma, as diferentes fontes de luz utilizadas para fotoativar tanto o sistema adesivo quanto a resina composta, de acordo com a análise estatística, produziram padrões semelhantes de micropermeabilidade. Analisando-se as distribuições percentuais dos escores de micropermeabilidade (Tabela 19), observou-se que as combinações que utilizaram QTH para polimerizar a resina composta (QTH/QTH, LED/QTH e PAC/QTH) apresentaram as menores porcentagens de micropermeabilidade na camada híbrida propriamente dita (escore 3). A combinação PAC/QTH apresentou a menor porcentagem de escore 3, enquanto que LED/PAC e PAC/LED, apresentaram as maiores. Um estudo que avaliou a nanoinfiltração em restaurações que utilizaram o Adper Single Bond como agente adesivo mostrou deposição de prata em algumas 
regiões na base e no interior de toda a espessura da camada híbrida ${ }^{135}$. Atribuiu-se a deposição de prata no interior da camada híbrida à regiões de incompleta infiltração de monômeros ou de incompleta polimerização, representando, assim, caminhos de penetração de fluidos.

Apesar de, no presente estudo, observar-se uma alta porcentagem de conversão de monômeros quando da utilização das diferentes fontes de luz para fotoativar o Adper Single Bond, não foi ainda demonstrado na literatura o quanto este material está polimerizado em dentina úmida. A porosidade da camada híbrida deve aumentar sensivelmente com o tempo, proporcionando alterações morfológicas da interface adesiva. ${ }^{71} \mathrm{~A}$ absorção de água e dissolução dos monômeros resinosos incompletamente polimerizados, principalmente de monômeros hidrofílicos como o HEMA, leva a uma deterioração da matriz resinosa e da resistência de união ${ }^{77,170}$. Vários estudos avaliaram a resistência adesiva in vitro ${ }^{19,72,148}$, alguns deles revelando a existência de caminhos de infiltração (leakage pathway) na interface adesiva $^{147,149}$. Esses caminhos permitem a permeação de fluidos na camada híbrida ou na camada de adesivo ${ }^{172}$. Este fenômeno deve causar a extração de monômeros solúveis em água e também de oligômeros de baixo peso molecular, levando à degradação da união adesiva entre resina e dentina ${ }^{169}$.

A aplicação de adesivos contendo HEMA em dentina úmida, como é o caso do Adper Single Bond, deve, ainda, favorecer a formação de domínios de hidro-géis microporosos, que compreendem polímeros localizados de $\mathrm{HEMA}^{171}$, os quais permitem a movimentação de água, íons e moléculas polares ${ }^{57}$. Por outro lado, o BisGMA é um monômero hidrofóbico viscoso, que não é capaz de se dispersar por entre as moléculas de água na matriz expandida de fibrilas de colágeno. Devido às suas características hidrofóbicas, não somente diluentes como HEMA ou TEGDMA, mas também solventes, como os solventes etanol e acetona, combinam-se para se difundirem no substrato dentinário. No monômero HEMA, por ser monofuncional, ocorre uma menor polimerização quando comparado ao BisGMA ${ }^{82}$, resultando em menores cadeias poliméricas ${ }^{157}$. Espera-se, portanto, que haja uma menor tensão de contração nos tags de resina, independente da fonte de luz fotoativadora, já que os mesmos são formados, em sua grande maioria, por monômeros de HEMA, em relação à quantidade de BisGMA ${ }^{157}$. 
Apesar de haver pouca informação de como é a relação da água com o processo de polimerização dos diferentes componentes do sistema adesivo, monômeros hidrofílicos têm sido adicionados a estes materiais restauradores ${ }^{160}$. A composição da camada híbrida dependerá da infiltração da mistura do primer contendo HEMA e da infiltração do HEMA/BisGMA por entre a trama de fibrilas de colágeno. Pode-se ainda afirmar que, além de monômeros resinosos, há a presença de uma certa concentração de fotoiniciadores por entre as fibrilas de colágeno. Desta forma, o grau de polimerização deve variar ao longo da camada híbrida, o que causariam variações significantes na qualidade da mesma em diferentes localizações ${ }^{81}$. Uma vez que o teste de micropermeabilidade foi relacionado à nanoinfiltração, sugerindo possíveis caminhos para a permeabilidade da camada híbrida $^{62,64}$, pode-se afirmar que as combinações QTH/QTH e PAC/QTH devem apresentar maior longevidade das restaurações adesivas, pois apresentam maiores concentrações dos melhores escores de micropermeabilidade (escores 1 e 2) e menores porcentagens de micropermeabilidade da camada híbrida (escore 3).

A importância dos tags de resina para o selamento efetivo da interface é até agora desconhecido, mas a união entre a dentina peritubular e a resina pode ser considerada fundamental para se avaliar a permeabilidade da interface adesiva ${ }^{64}$. A permeação dos monômeros resinosos na dentina desmineralizada deve integrar-se com os tags de resina para a formação da camada híbrida, promovendo tanto o selamento, bem como o desenvolvimento de uma alta resistência de união adesiva entre dente/restauração ${ }^{176}$. Na verdade, os tags de resina podem contribuir para melhorar a resistência adesiva de várias formas. Devido à convergência dos túbulos dentinários em direção à polpa, a penetração deve gerar retenção mecânica, uma vez que os tags formados são divergentes ${ }^{107}$. Além disso, idealmente, deve haver união micromecânica entre a parede interna dos túbulos e os tags de resina. Assim, a possibilidade de desunião ficaria reduzida à fratura coesiva dos mesmos na superfície dos túbulos ${ }^{108}$. Procurou-se, neste estudo, dar uma atenção especial à avaliação da homogeneidade dos tags de resina no interior dos túbulos dentinários, bem como ao padrão de adaptação às paredes dos túbulos dentinários, referido como qualidade dos tags de resina. 
Em termos de qualidade dos tags de resina, verificou-se que, embora não houvesse diferença significante entre os grupos experimentais (Tabela 20), a combinação QTH/QTH apresentou as maiores porcentagens de melhores escores. Em geral, as combinações que utilizaram QTH para polimerizar o sistema adesivo apresentaram as mais altas porcentagens de escore 1 e 2 (cerca de $90 \%$ ) para qualidade dos tags de resina. Por outro lado, quando LED foi utilizado para o mesmo material, altas porcentagens de piores escores estiveram presentes, especialmente para a combinação LED/PAC (cerca de 38 \%).

No presente estudo, a habilidade de selamento foi baseada na avaliação da extensão em que a solução contendo o corante fluorescente verde, aplicada na câmara pulpar, penetrou por entre os tags de resina em direção à camada híbrida. A qualidade dos tags de resina parece ter refletido na habilidade de selamento dos mesmos. Da mesma forma, embora não se encontrou diferença significante entre os grupos experimentais (Tabela 20), a combinação QTH/QTH apresentou maiores porcentagens do melhor escore para habilidade de selamento dos tags (escore $1=$ $63,6 \%$ ). Quando PAC foi utilizado para polimerizar a resina composta, observou-se claramente a influência negativa desta fonte de luz na redução da habilidade de selamento dos tags de resina. Por exemplo, no caso da combinação LED/PAC, houve a ocorrência de mais de 50 \% dos piores escores para habilidade de selamento. Além disso, a combinação PAC/PAC apresentou as menores porcentagens de melhor escore para este parâmetro (25 \%). Desta forma, fica comprovada a influência da tensão de contração de polimerização no aumento da permeabilidade da interface adesiva.

Tem-se afirmado que baixos valores de resistência adesiva são causados por uma alta incidência de fendas na interface dentina-resina composta, devido à distribuição não homogênea das tensões de contração de polimerização ${ }^{197}$ e à subseqüente ação de fatores térmicos, químicos e mecânicos ${ }^{67}$. As diferentes combinações de fontes de luz influenciaram na extensão de fendas na interface adesiva. A análise estatística mostrou que as combinações PAC/QTH e PAC/PAC apresentaram valores significantemente menores em comparação à combinação QTH/LED. A extensão das fendas em restaurações de resina composta registradas na literatura varia de 0,5 a $20 \mu \mathrm{m} .{ }^{75}$ No presente estudo, essa extensão variou entre 
15 a $52 \mu \mathrm{m}$ (Tabela 25) e foi influenciada não somente pelas diferentes fontes de luz que fotoativaram o sistema adesivo, mas também pelo alto fator de configuração do preparo cavitário (Fator "C" 2,9).

Em termos de porcentagem, verificaram-se que as fendas compreenderam de 7 a $22 \%$ do total da extensão da interface na base de restaurações de classe I. HANNIG \& FRIEDRICHS ${ }^{68}$ encontraram uma porcentagem de fendas internas em restaurações avaliadas in vivo variando entre 14 e $54 \%$ do total da interface, dependendo do material e da técnica de fotoativação utilizada. Apesar de alguns estudos mostrarem que a alta intensidade de luz é causadora de fendas marginais e pobre adaptação da resina composta às paredes internas dos preparos ${ }^{196}$, os resultados do presente estudo são parcialmente corroborados por esta afirmação. Por exemplo, nas combinações em que o PAC foi utilizado para polimerizar a resina composta, fendas existentes entre a camada de adesivo e a resina composta foram freqüentes (escores 2 e 7). Por outro lado, a presença destas fendas foi também observada quando o LED polimerizou a resina composta, destacando-se as combinações LED/LED (56,1 $\mu \mathrm{m})$ e QTH/LED $(52,7 \mu \mathrm{m})$.

Entretanto, as diferentes combinações de fontes de luz não exerceram influência na localização de fendas na interface adesiva. Não foi observada diferença significante entre os grupos experimentais. Apesar disso, verificou-se que as combinações LED/LED e QTH/LED, além de LED/PAC, apresentaram as maiores porcentagens de fenda entre a camada de adesivo e a camada híbrida (escores 4 e 5). Tem sido relatado na literatura que a ocorrência dessas fendas é mais freqüente em áreas em que a camada de adesivo se encontra mais fina ${ }^{80}$, o que foi verificado no presente estudo. A combinação PAC/QTH apresentou as maiores porcentagens de interfaces livres de fendas (cerca de $62 \%$ ). Verificou-se também que não houve ocorrência de piores escores para localização de fenda (escores 5, 6 e 7) para esta combinação (Figura 59). Observaram-se, ainda, as maiores porcentagens de ausência de micropermeabilidade na camada híbrida (82 \%) e maior espessura da camada de adesivo $(11,9 \mu \mathrm{m})$ para esta combinação, além de uma das maiores porcentagens de habilidade de selamento $(68,7 \%)$ e de qualidade dos tags de resina $(90 \%)$. Todos estes fatores devem ter contribuído para a maior resistência adesiva mostrada pela combinação PAC/QTH. Já as combinações LED/LED e 
LED/PAC apresentaram menores porcentagens de interface livre de fendas $(34,4$ e $34,5 \%$, respectivamente), comparadas às demais combinações.

De acordo com a análise estatística, a fonte de luz utilizada para fotoativar o sistema adesivo teve uma influência significante em ambos os parâmetros de fendas. Quando o PAC foi utilizado para o sistema adesivo, obtiveram-se valores significantemente menores para ambos os parâmetros de fenda, independente da fonte de luz que polimerizou a resina composta. Como visto anteriormente, na avaliação dos parâmetros de cinética de conversão, o PAC forneceu porcentagem significantemente menor de conversão de monômeros quando comparado às porcentagens obtidas com LED e QTH, o que deve ter permitido uma menor tensão de contração de polimerização para o sistema adesivo. Também, como já destacado anteriormente, a utilização do PAC para o sistema adesivo possibilitou a formação de uma camada de adesivo mais espessa, que representa um importante fator para o alívio das tensões geradas durante a contração de polimerização da resina composta.

As hipóteses de que diferentes fontes de luz fotoativadoras, para polimerizar tanto a resina composta quanto o sistema adesivo, não influenciariam na micromorfologia da interface adesiva nem nos parâmetros de avaliação de fendas foram, então, parcialmente rejeitadas. As diferentes fontes de luz promoveram diferença significante na espessura da camada de adesivo e na extensão da fenda. Estes parâmetros foram influenciados pela fonte de luz que polimerizou o sistema adesivo e não pela utilizada para a resina composta. A localização das fendas também foi influenciada pelo aparelho fotoativador que polimerizou o adesivo. Além disso, utilizando-se o PAC para o adesivo observaram-se espessuras de camada de adesivo significantemente maiores e menor extensão de fendas.

\section{3- Resistência de União Adesiva}

Os testes de microtração têm sido muito utilizados para a avaliação da força de união da restauração adesiva ao esmalte e à dentina ${ }^{107,}{ }^{145}$. Para minimizar a influência do preparo cavitário na interpretação dos resultados de resistência adesiva, os materiais adesivos são aplicados, via de regra, em superfícies 
dentinárias planas, sem paredes circundantes, praticamente anulando o efeito do fator C. No presente trabalho, porém, foram realizadas restaurações de resina composta de classe I para análise da resistência adesiva em situação mais próxima da realidade clínica. Assim, alguns cuidados foram tomados para que se minimizassem as interferências dessa condição nos resultados. Por exemplo, após o término dos procedimentos restauradores, os dentes foram armazenados por 24 horas em água destilada para que, em seguida, se realizasse o acréscimo de resina composta sobre as restaurações. Desta forma, evitou-se a influência da fonte de luz fotoativadora sobre a resina composta do interior da cavidade, o que certamente ocorreria se aplicada imediatamente aos procedimentos restauradores. A quantidade de resina composta adicionada possibilitou que se obtivessem espécimes com a mesma extensão de resina composta e de dentina, o que certamente contribuiu para a obtenção de resultados mais confiáveis, além de facilitar a fixação dos espécimes para o teste de tração.

As restaurações de resina composta de classe I foram intencionalmente selecionadas por estarem relacionadas ao desenvolvimento de maiores tensões de contração nas paredes internas dos preparos ${ }^{184}$. Pode-se ainda questionar a utilização de uma espessura de $2,5 \mathrm{~mm}$ de resina composta, aplicada na forma de incremento único, o que poderia influenciar os resultados obtidos. Isto se daria pelo fato de haver a possibilidade de regiões com propriedades comprometidas na base restauração, mesmo quando foram utilizados LED e PAC ${ }^{183}$. Apesar dos preparos cavitários, no presente estudo, serem bastante amplos, a espessura da resina composta correspondeu ao limite dos valores clinicamente aceitáveis, além de ser a espessura máxima recomendada pelo fabricante. Alguns autores sugerem que a profundidade de polimerização deve ser definida como o nível em que os valores de dureza são equivalentes a pelo menos $90 \%$ dos valores de dureza no topo da resina composta ${ }^{84}$. Outros têm sugerido que o gradiente topo/base da restauração, em termos de conversão de monômeros, não deveria ser menor que 80 \%. Esses valores são considerados uma avaliação realista da profundidade de polimerização ${ }^{12,183}$. A conversão na base da resina composta Filtek Z250, em espécimes de $2,5 \mathrm{~mm}$ de espessura, avaliada no presente estudo, foi de $44,3 \%$ quando polimerizado com QTH, com resultados similares com LED $(45,5 \%)$ e 
significantemente maiores com PAC (49,2 \%). A porcentagem de conversão total no topo dos espécimes de resina composta foi de 52\% (Anexo 3), independente da fonte de luz utilizada, indicando que o gradiente topo/base da restauração foi de pelo menos 84 \% (para QTH). Assim, a uma profundidade de 2,5 mm, todos os aparelhos fotoativadores foram capazes de polimerizar adequadamente a resina composta. A maioria dos estudos que avaliaram restaurações de resina composta enfatiza a importância dos aparelhos fotoativadores e da cinética de conversão de monômeros, especialmente do parâmetro taxa de conversão e a correlação com as tensões resultantes nas margens das restaurações e suas conseqüências. Raramente um estudo avaliou a influência de diferentes fontes de luz sobre os sistemas adesivos e sobre os diferentes parâmetros de conversão e, conseqüentemente, a resistência de união adesiva.

O teste de resistência adesiva foi realizado seguindo-se o protocolo descrito por Sano et al. ${ }^{146}$. Porém, como se tratavam de restaurações de classe I, áreas de ângulo foram descartadas por haver acúmulo de adesivo (pooling) nestas regiões ${ }^{168}$. A área de dentina pulpar também foi desprezada devido à pequena espessura de dentina remanescente e à dificuldade da obtenção de espécimes pelo processo de desgaste (trimming). Neste caso, os espécimes são em forma de ampulheta, diferente da forma dos espécimes obtidos no presente estudo (palitos). Devido à diferença na distribuição das forças quando da realização do teste de microtração, diferentes formas de espécimes levariam a resultados não homogêneos, impossibilitando a comparação dos valores.

Os valores gerais de resistência de união adesiva obtidos no presente estudo podem ser explicados, não somente pelo alto fator $\mathrm{C}$ dos preparos cavitários de classe I, mas também pela influência das diferentes fontes que polimerizaram o sistema adesivo. A hipótese de que a utilização de diferentes fontes de luz fotoativadoras para polimerizar tanto a resina composta quanto o sistema adesivo, não exerce influência na resistência de união adesiva foi também rejeitada. Além disso, a resistência adesiva foi influenciada também pela fonte de luz que polimerizou o sistema adesivo. Quando o PAC e QTH foram utilizados, foram obtidos valores mais altos de união adesiva em comparação com o LED. NUNES et al. ${ }^{103}$, avaliando a resistência adesiva em restaurações de resina composta que receberam 
diferentes sistemas adesivos, encontraram valores em torno de 75,9 MPa para Adper Single Bond quando aplicado em uma superfície plana de dentina. Estes autores utilizaram um aparelho QTH (com densidade de potência de $400 \mathrm{~mW} / \mathrm{cm}^{2}$ ) para fotoativar os sistemas adesivos e a resina composta. Os resultados obtidos foram semelhantes aos observados no presente estudo quando da realização dos testes preliminares (72 MPa), que também utilizaram superfície plana de dentina.

Os resultados do presente estudo revelaram que a utilização de diferentes aparelhos fotoativadores para polimerizar ambos os materiais restauradores produziu valores de resistência adesiva não homogêneos. As combinações PAC/QTH e QTH/QTH apresentaram valores significantemente maiores de resistência adesiva comparados ao LED/QTH (Tabela 29). Os valores de resistência do PAC/QTH foram ainda significantemente maiores que os valores apresentados pela combinação LED/PAC. Baseado, ainda, na análise estatística dos resultados deste estudo, pode-se afirmar que os valores de resistência de união adesiva em restaurações de resina composta foram mais dependentes da fonte de luz que polimerizou o sistema adesivo, que a aplicada para a polimerização da resina composta (Tabela 30). A taxa máxima de conversão é o principal fator relacionado com a tensão ao longo da interface dente/restauração ${ }^{51}$. Apesar do PAC apresentar uma porcentagem significantemente maior de taxa máxima de conversão, em menor tempo, o fator mais importante em termos de resistência adesiva parece ter sido o menor grau de conversão total de monômeros na máxima taxa de conversão para o sistema adesivo utilizado. Desta forma, poderia minimizar a geração de tensões resultantes da contração de polimerização no sistema adesivo, em comparação à observada quando se utilizou o LED. Adicionalmente, quando a resina composta foi polimerizada com QTH, poderia haver um menor desenvolvimento de tensões nas margens, bem como nas paredes internas das restaurações, devido aos parâmetros de cinética de conversão mais favoráveis (menor grau de conversão; menor máxima taxa de conversão; tempo mais longo em que ocorreu a máxima taxa). Estes fatores devem explicar o porquê da combinação PAC/QTH apresentar maior resistência adesiva.

Além disso, como relatado anteriormente, observou-se uma menor ocorrência de fendas na interface da parede pulpar de restaurações de resina quando o PAC 
polimerizou o adesivo Adper Single Bond, independente da fonte de luz que para a resina composta. A combinação PAC/QTH apresentou a maior porcentagem de ausência de fendas (ao redor de 62 \%). Tem sido relatado que maiores valores de resistência de união adesiva ocorrem quando há menores extensões de fenda ${ }^{119}$. Entretanto, no presente estudo, encontrou-se uma fraca correlação entre extensão de fendas e resistência adesiva $\left(R^{2}=0,1452\right.$ - Anexo 5), quando se compararam os resultados das combinações avaliadas. A magnitude do estresse gerado na polimerização de restaurações de resina composta é então influenciada por uma série de fatores relacionados aos materiais restauradores, à técnica e ao preparo cavitário $^{197}$, sendo que a inter-relação entre estes fatores determinam a manifestação da contração para uma dada restauração adesiva ${ }^{119}$. Não somente a extensão de fendas é importante, mas também a sua localização. JACOBSEN et al. $^{83}$ verificaram baixos valores de resistência quando fendas foram mais freqüentemente localizadas na transição entre a camada de adesivo e a camada híbrida, e especialmente em áreas em que a camada de adesivo era mais fina.

Por outro lado, os mesmos fatores acima mencionados não explicam a baixa resistência adesiva observada na combinação LED/QTH. A análise estatística revelou que quando o LED polimerizou o sistema adesivo, valores significantemente menores de resistência adesiva foram obtidos em comparação ao QTH e PAC (Tabela 30), independente da fonte de luz que polimerizou a resina composta. Além disso, outras razões seriam, provavelmente, pelos resultados negativos de fendas e alta porcentagem de conversão de monômeros quando o LED foi utilizado para polimerizar o sistema adesivo. Ainda, a polimerização do sistema adesivo com LED promoveu, proporcionalmente, maiores porcentagens de conversão na máxima taxa em relação à conversão total de monômeros. Os problemas clínicos proporcionados pelo alto grau de conversão, em um menor tempo, estão relacionados com as tensões geradas durante a contração de polimerização. A polimerização do adesivo com LED deve der produzido a geração de maiores tensões na interface, principalmente quando PAC foi utilizado para polimerizar a resina composta.

As combinações LED/LED e LED/PAC apresentaram maior resistência adesiva em comparação à combinação LED/QTH, apesar da ausência de significância entre estes grupos. Desta forma, os resultados sugerem que os 
aparelhos LED e PAC, com alta densidade de potência, devem ter promovido uma conversão de monômeros adicional tardia no sistema adesivo, já que alguns fótons foram capazes de atingir a interface adesiva, apesar da espessura da resina composta. Apesar do LED promover menor resistência adesiva quando polimerizou o sistema adesivo, as combinações que utilizaram LED para resina composta promoveram valores mais homogêneos de resistência, independente da fonte de luz que polimerizou o sistema adesivo (Figura 63). Quando o QTH polimerizou a resina composta, obteve-se uma resistência adesiva significantemente maior com PAC para o sistema adesivo e significantemente menor com LED para o este material. PAC para a resina composta apresentou valores homogêneos quando combinado com QTH e PAC para o sistema adesivo, mas baixos valores quando combinado com LED (LED/PAC).

De forma geral, a combinação PAC/QTH apresentou os maiores valores de resistência adesiva, a maior espessura da camada de adesivo e uma das maiores porcentagens de habilidade de selamento dos tags de resina. Além disso, esta combinação apresentou maiores porcentagens de ausência de micropermeabilidade e menores extensões de fenda. Assim, a utilização de aparelhos fotoativadores com amplo espectro de luz e com alta intensidade de luz (PAC) para fotoativar o sistema adesivo e baixa (QTH) para polimerizar a resina composta parece ser mais favorável para uma maior longevidade das restaurações adesivas. Alguns dos parâmetros quantitativos e qualitativos analisados foram significantemente dependendes da luz que polimerizou o adesivo. Desta forma, tornou-se clara a influência das diferentes fontes de luz na micromorfologia da interface e estruturas vizinhas, bem como na formação de fendas e na resistência adesiva.

Quando se compararam combinações que utilizaram a mesma fonte de luz, a análise estatística mostrou resultados similares para os parâmetros qualitativos de micromorfologia da interface adesiva. Entretanto, a combinação QTH/QTH apresentou menor porcentagem para micropermeabilidade da camada híbrida e maior habilidade de selamento dos tags de resina. PAC/PAC apresentou, de forma contrastante, alta qualidade da camada híbrida, mas ao mesmo tempo alta porcentagem de micropermeabilidade nessa região (38\%). A combinação LED/LED apresentou alta micropermeabilidade além da camada híbrida (13\%) e alta 
porcentagem para baixa qualidade de tags de resina $(20,6 \%)$. Para ambos os parâmetros de fenda estudados, houve resultados completamente diferentes quando combinações com mesma fonte de luz foram comparadas. PAC/PAC apresentou menores valores de extensão de fenda $(19,14 \mu \mathrm{m})$, comparado a QTH/QTH e LED/LED, sendo significantemente diferente em relação a esta última combinação. Além disso, PAC/PAC apresentou maior porcentagem de interfaces livres de fendas, comparadas às demais combinações, e quase total ausência de escores piores. LED/LED apresentou uma das maiores porcentagens de extensão de fenda $(56,14$ $\mu \mathrm{m})$. A combinação QTH/QTH apresentou resultado intermediário (35,80 $\mu \mathrm{m})$.

Em termos de resistência adesiva, as combinações que utilizaram mesma fonte de luz apresentaram valores similares. A maior tensão de contração de polimerização na resina composta que seria causada quando polimerizada com o PAC, deve ter sido compensada pela menor tensão de contração quando o sistema adesivo foi polimerizado com o mesmo aparelho. A combinação LED/LED apresentou menor resistência adesiva em comparação às combinações QTH/QTH e PAC/PAC, provavelmente devido aos efeitos da contração de polimerização quando esta fonte de luz foi utilizada para ambos materiais restauradores, já que houve maior conversão de monômeros na máxima taxa de conversão.

O aparelho LED, utilizado no presente estudo, mostrou resultados preocupantes em alguns dos parâmetros analisados, como grandes extensões de fenda. Por outro lado, PAC mostrou resultados muitas vezes surpreendentes, como baixos valores de extensão de fendas e médios valores de resistência adesiva. Embora não existam no mercado aparelhos que utilizem diferentes fontes de luz fotoativadoras, pode-se afirmar que, pelos resultados gerais, o aparelho fotoativador convencional com lâmpada halógena, para polimerizar tanto a resina composta como o sistema adesivo, ainda pode ser considerado como controle, já que foi desenvolvido para a grande maioria dos procedimentos clínicos ${ }^{137}$. 


\section{7- Conclusões}




\section{7- Conclusões}

Baseado nos resultados obtidos pode-se concluir que:

1. A cinética de conversão de monômeros é influenciada pelas diferentes fontes de luz fotoativadoras utilizadas para polimerizar o sistema adesivo;

2. A cinética de conversão de monômeros é influenciada pelas diferentes fontes de luz fotoativadoras utilizadas para polimerizar a resina composta (base);

3. As diferentes combinações de fontes de luz exercem influência na espessura da camada de adesivo. A espessura desta camada é mais influencida pela fonte de luz que polimeriza o sistema adesivo do que aquela que fotoativa a resina composta;

4. As diferentes combinações de fontes de luz não exercem influência na espessura e qualidade da camada híbrida;

5. As diferentes combinações de fontes de luz não exercem influência na qualidade e habilidade de selamento dos tags de resina;

6. As diferentes combinações de fontes de luz não exercem influência nos padrões de micropermeabilidade;

7. As diferentes combinações de fontes de luz exercem influência na extensão de fendas. Em relação à análise qualitativa de fendas, as diferentes combinações de fontes de luz não exercem influência na localização das mesmas. A fonte de luz PAC para fotoativar o sistema adesivo influencia ambos os parâmetros de fenda (extensão e localização), apresentando os melhores resultados, independente da fonte de luz utilizada para a resina composta;

8. As diferentes combinações de fontes de luz exercem influência na resistência de união adesiva. Os resultados são mais influenciados pela fonte de luz que fotoativa o sistema adesivo do que a utilizada para a resina composta. As fontes de luz PAC e QTH para fotoativar o sistema adesivo influenciam positivamente na resistência de união adesiva, independente da fonte de luz utilizada para a resina composta; 
9. As combinações QTH/QTH, LED/LED e PAC/PAC possuem, de forma geral, resultados similares. Dos parâmetros analisados, apenas os valores de extensão de fendas são influenciados pelas combinações de mesma fontes de luz, sendo que a combinação PAC/PAC possui valores significantemente menores do que a combinação LED/LED. 
Anexos 


\section{Anexos}

Anexo 1 - Resultados da avaliação da cinética de conversão de monômeros em espectroscopia de raios infravermelho para sistema adesivo

\begin{tabular}{|c|c|c|c|c|c|}
\hline $\begin{array}{c}\text { Aparelho } \\
\text { Fotoativador }\end{array}$ & $\begin{array}{c}\text { Conversão } \\
\text { de } \\
\text { Monômeros } \\
(\%)\end{array}$ & $\begin{array}{c}\text { Taxa } \\
\text { Máxima de } \\
\text { Conversão } \\
(\% / \text { seg. })\end{array}$ & $\begin{array}{l}\text { Tempo em } \\
\text { que } \\
\text { ocorreu a } \\
\text { Máxima } \\
\text { Taxa } \\
\text { (seg.) }\end{array}$ & $\begin{array}{c}\text { Conversão } \\
\text { na Máxima } \\
\text { Taxa } \\
(\%)\end{array}$ & $\begin{array}{c}\text { Relação } \\
\text { Conversão } \\
\text { Máxima } \\
\text { Taxa/ } \\
\text { Conversão } \\
\text { Total } \\
(\%)\end{array}$ \\
\hline QTH & $98,1(2,0)$ & $14,6(0,8)$ & $6,0(0,7)$ & $44,8(7,7)$ & 45,6 \\
\hline LED & $93,8(3,0)$ & $14,9(0,9)$ & $5,4(0,9)$ & $45,4(10,5)$ & 48,4 \\
\hline PAC & $92,2(3,9)$ & $16,6(1,3)$ & $4,0(1,0)$ & $34,4(4,7)$ & 37,3 \\
\hline
\end{tabular}

$\mathrm{n}=5$

Números entre parênteses: devio-padrão 
Anexo 2 - Resultados da avaliação da cinética de conversão de monômeros em espectroscopia de raios infravermelho para resina composta (base)

\begin{tabular}{|c|c|c|c|c|c|}
\hline $\begin{array}{c}\text { Aparelho } \\
\text { Fotoativador }\end{array}$ & $\begin{array}{c}\text { Conversão } \\
\text { de } \\
\text { Monômeros } \\
(\%)\end{array}$ & $\begin{array}{c}\text { Taxa } \\
\text { Máxima } \\
\text { de } \\
\text { Conversão } \\
\text { (\% / seg.) }\end{array}$ & $\begin{array}{c}\text { Tempo em } \\
\text { que } \\
\text { ocorreu a } \\
\text { Máxima } \\
\text { Taxa } \\
\text { (seg.) }\end{array}$ & $\begin{array}{c}\text { Conversão } \\
\text { na } \\
\text { Máxima } \\
\text { Taxa } \\
(\%)\end{array}$ & $\begin{array}{c}\text { Relação } \\
\text { Conversão } \\
\text { Máxima } \\
\text { Taxa/ } \\
\text { Conversão } \\
\text { Total } \\
(\%)\end{array}$ \\
\hline QTH & $44,3(0,7)$ & $5,3(0,5)$ & $5,6(0,4)$ & $11,3(3,2)$ & 25,3 \\
\hline LED & $45,5(1,1)$ & $6,8(0,9)$ & $4,2(0,8)$ & $12,9(2,1)$ & 28,3 \\
\hline PAC & $49,2(0,7)$ & $9,8(1,1)$ & $3,2(0,4)$ & $11,9(3,4)$ & 24,2 \\
\hline
\end{tabular}

$\mathrm{n}=5$

Números entre parênteses: devio-padrão 
Anexo 3 - Resultados da avaliação da cinética de conversão de monômeros em espectroscopia de raios infravermelho para resina composta (topo)

\begin{tabular}{|c|c|c|c|c|c|}
\hline $\begin{array}{c}\text { Aparelho } \\
\text { Fotopolimerizador }\end{array}$ & $\begin{array}{c}\text { Conversão } \\
\text { de } \\
\text { Monômeros } \\
(\%)\end{array}$ & $\begin{array}{c}\text { Taxa } \\
\text { Máxima } \\
\text { de } \\
\text { Conversão } \\
\text { (\% / seg.) }\end{array}$ & $\begin{array}{l}\text { Tempo em } \\
\text { que } \\
\text { ocorreu a } \\
\text { Máxima } \\
\text { Taxa } \\
\text { (seg.) }\end{array}$ & $\begin{array}{c}\text { Conversão } \\
\text { na Máxima } \\
\text { Taxa } \\
(\%)\end{array}$ & $\begin{array}{c}\text { Relação } \\
\text { Conversão } \\
\text { Máxima } \\
\text { Taxa/ } \\
\text { Conversão } \\
\text { Total } \\
(\%)\end{array}$ \\
\hline QTH & $52,3(0,7)$ & $15,2(1,6)$ & $3,2(0,4)$ & $19,2(3,2)$ & 36,7 \\
\hline LED & $52,2(1,1)$ & $16,3(1,5)$ & $3,2(0,8)$ & $18,9(0,4)$ & 26,2 \\
\hline PAC & $51,4(0,9)$ & $21,4(2,8)$ & $2,8(0,4)$ & $21,9(2,6)$ & 42,2 \\
\hline
\end{tabular}


Anexo 4 - Análise da correlação entre densidade de potência $\left(\mathrm{mW} / \mathrm{cm}^{2}\right)$ e a taxa máxima de conversão (\%/segundo) para resina composta

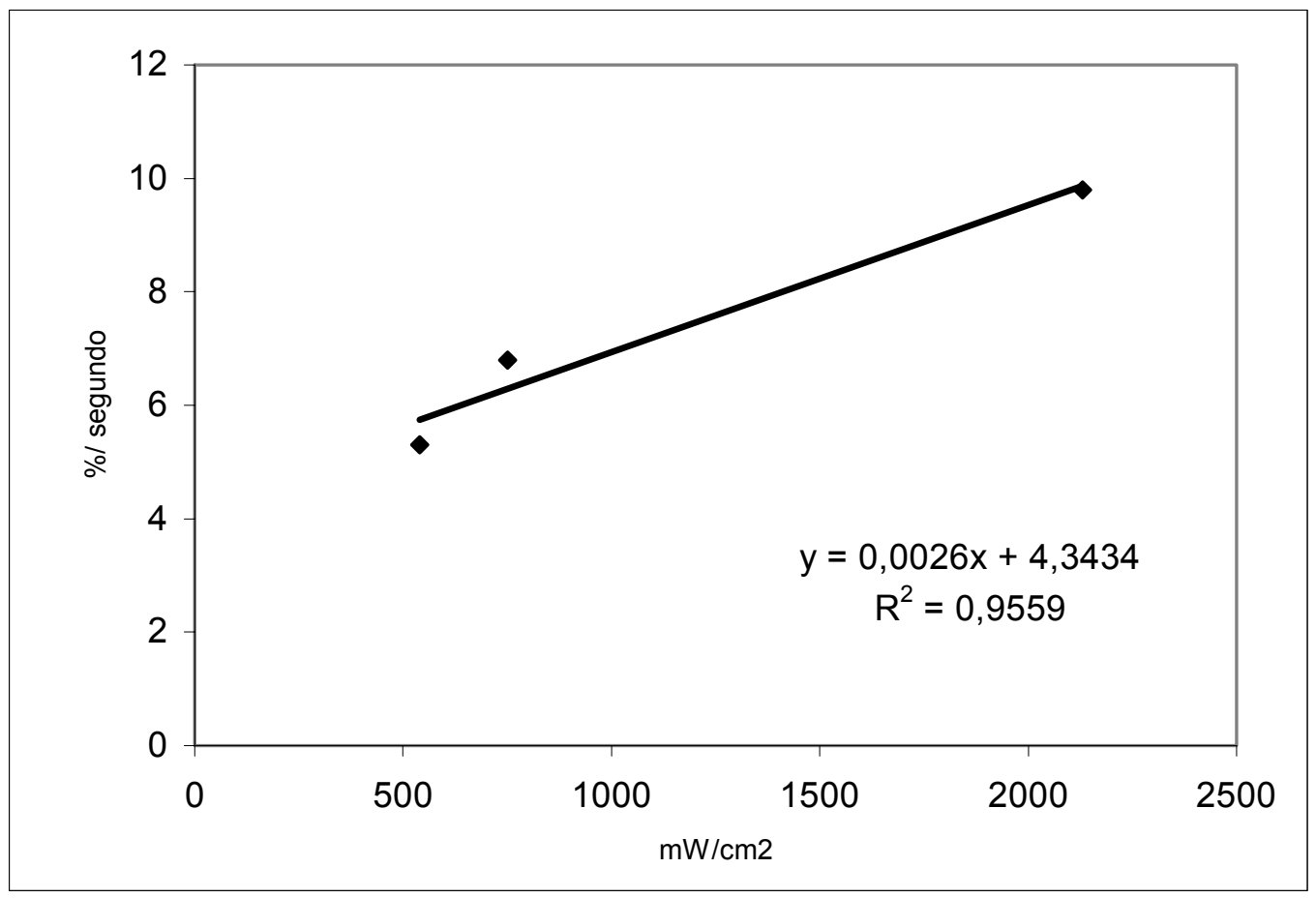


Anexo 5- Análise da correlação entre resistência adesiva e a extensão de fendas

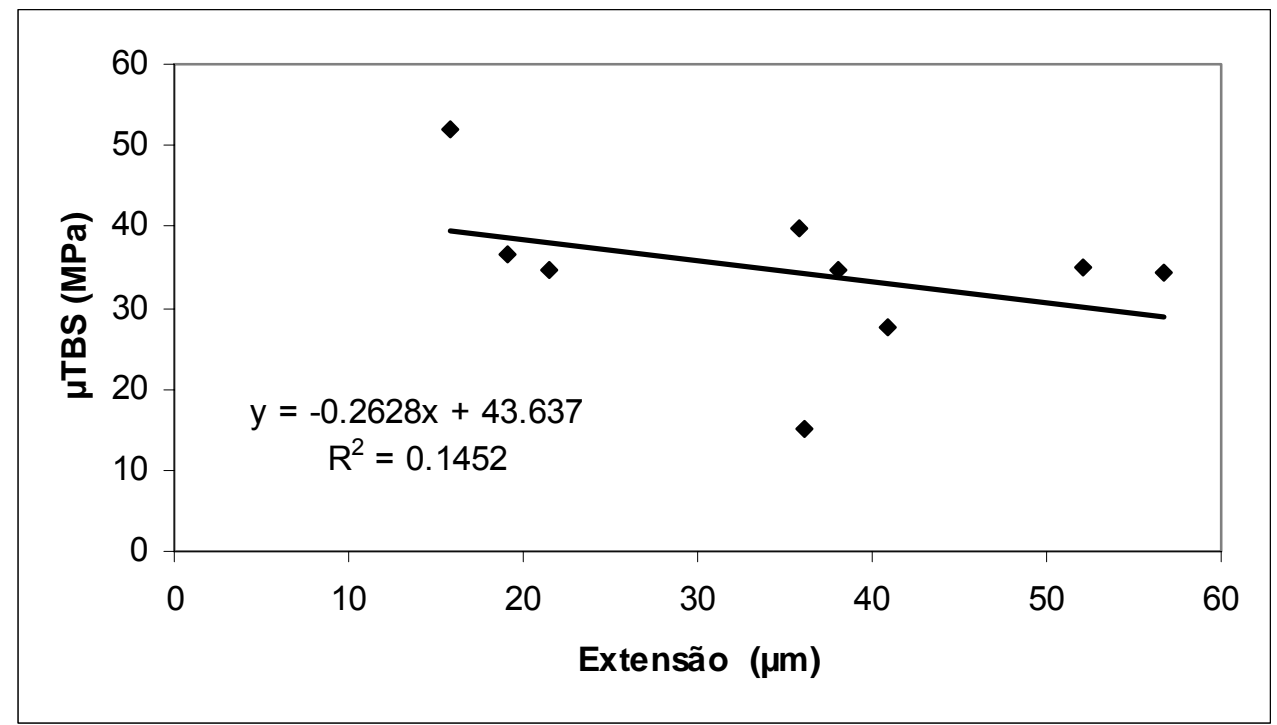


Anexo 6 - Corantes fluorescentes e traçadores comumente utilizados em microscopia ótica

\begin{tabular}{|c|c|c|c|c|c|}
\hline Corantes Fluorescente & $\begin{array}{c}\text { Peso } \\
\text { Molecular }\end{array}$ & $\begin{array}{l}\text { Raio da } \\
\text { Molécula } \\
\text { (nm) }\end{array}$ & $\begin{array}{c}\text { Comprimento } \\
\text { de onda de } \\
\text { Excitação } \\
(\mathrm{nm})\end{array}$ & $\begin{array}{c}\text { Comprimento } \\
\text { de onda de } \\
\text { Emissão } \\
(\mathrm{nm})\end{array}$ & $\begin{array}{c}\text { Coeficiente } \\
\text { Extinção } \\
\text { Molar } \\
\left(\mathrm{M}^{-1} \mathrm{~cm}^{-1}\right) \\
\end{array}$ \\
\hline Rodamina B & 479 & 0,78 & 540 & 585 & 106,000 \\
\hline Rodamina B (isothiocyanate) & 536 & 0,81 & 570 & 595 & 107,000 \\
\hline Fluoresceína Sódica (FITC) & 376 & 0,50 & 495 & 520 & 83,000 \\
\hline Fluoresceína (isothiocyanate) & 389 & 0,73 & 496 & 549 & 72,000 \\
\hline Lucifer Yellow & 521 & 0,80 & 425 & 528 & 24,200 \\
\hline Acriflavina & 260 & 0,64 & 436 & 520 & 19,900 \\
\hline Auramina $\mathrm{O}$ & 304 & 0,67 & 460 & 550 & 25,300 \\
\hline Dextran-Fluoresceína & 3.000 & 14,42 & $780^{\mathrm{ii}}$ & 544 & 85,000 \\
\hline \multicolumn{6}{|c|}{ Traçadores comumente utilizados em microscopia ótica ${ }^{\mathrm{jj}}$} \\
\hline Azul de Metileno ${ }^{\mathrm{kk}}$ & 319 & 0,68 & & & \\
\hline Fucsina Básica & 585 & 0,84 & & & \\
\hline Prata $\left(\mathrm{AgNO}_{2}\right)$ & 108 & 0,50 & & & \\
\hline Água & 18 & 0,26 & & & \\
\hline
\end{tabular}

hh Cálculo: raiz cúbica do peso molecular dividido por 10 (Hilton, 2002)

ii Comprimento de onda de excitação com Two-Photon Laser

${ }^{\mathrm{ij}}$ Hilton, 2002

${ }^{\mathrm{kk}}$ Apresenta também propriedade de fluorêscencia 


\section{Referências Rihlinnráfinac}




\section{Referências Bibliográficas*}

1. ABDALLA A.I.; GARCIA-GODOY F. Morphological characterization of single bottle adhesives and vital dentin interface. Amer J Dent, v.15, n.1, p. 31-4, Feb. 2002.

2. AMARAL C.M. et al. Influence of resin composite polymerization techniques on microleakage and microhardness. Quintessence Int, v.33, n.9, p. 685-9, Oct. 2002.

3. AMARAL, C.M. et al. Microleakage and gap formation of resin composite restorations polymerized with different techniques. Amer J Dent,v.17, n.3, p. 156-60, June 2004.

4. ARRAIS C.A.; GIANNINI, M. Morphology and thickness of the diffusion of resin through demineralized or unconditioned dentinal matrix. Pesqui Odontol Bras, v.16, n.2, p. 115-20, Apr./June 2002.

5. ASMUSSEN, E.; PEUTZFELDT, A. Light-emitting diode curing: influence on selected properties of resin composites. Quintessence Int, v.34, n.1, p. 71-5, Jan. 2003.

6. ASMUSSEN, E.; PEUTZFELDT, A. Flexural strength and modulus of a step-cured resin composite. Acta Odontol Scand, v.62, n.2, p.87-90, Apr. 2004.

7. AUSIELlO, P.; APICELLA, A.; DAVIDSON, C.L. Effect of adhesive layer properties on stress distribution in composite restorations - a 3D finite element analysis. Dent Mater,v.18, n.4, p. 295-303, June 2002.

8. BANG, H.C, et al. Effect of plasma arc curing on polymerization shrinkage of orthodontic adhesive resins. J Oral Rehab, v.31, n.8, p.803-10, Aug. 2004.

\footnotetext{
* Normas recomendadas para uso no âmbito da Universidade de São Paulo, com base no documento "Referencias Bibliográficas: exemplos", emanado do Conselho Superior do Sistema Integrado de Bibliotecas da U.S.P., em reunião de 20 de Setembro de 1990.
} 
9. BESTVATER, F. et al. Two-photon fluorescence absorption and emission spectra of dyes relevant for cell imaging. J Microscopy, v.208, p.108-15, 2002.

10. BOUILLAGUET, S. et al. Ability of adhesive systems to seal dentin surfaces: an in vitro study. J Adhes Dent, v.2, n.3, p.201-8, Autumn. 2000.

11. BOUSCHLICHER, M.R.; RUEGGEBERG, F.A. Effect of ramped light intensity on polymerization force and conversion in a photoactivated composite. J Esthet Dent, v.12, n.6, p. 328-39, 2000.

12. BOUSCHLICHER, M.R.; RUEGGEBERG, F.A,; WILSON, B.M. Correlation of bottom-to-top surface microhardness and conversion ratios for a variety of resin composite compositions. Oper Dent, v.29, n.6, p.698-704, Nov./Dec. 2004.

13. BRAGA, R.R.; FERRACANE, J.L. Contraction stress related to degree of conversion and reaction kinetics. J Dent Res, v.81, n.2, p.114-8, Feb. 2002.

14. BRAGA, R.R.; FERRACANE, J.L. Alternatives in polymerization contraction stress management. Crit Rev Oral Biol Med, v.15, n.3, p.176-84, 2004.

15. BURROW, M.F.; INOKOSHI, S.; TAGAMI, J. Water sorption of several bonding resins. Amer J Dent, v.12, n.6, p. 295-8, Dec. 1999.

16. CALDWELL, R.; KULKARNI, G.; TITLEY, K. Does single versus stepped curing of composite resins affect their shear bond strength? J Canad Dent Assoc,v.67, n.10, p. 588-92, Nov. 2001.

17. CARRILHO, M.R. et al. Bond strength of four adhesive systems to dentin. Pesqui Odontol Bras, v.16, n.3, p.251-6, July/Sept. 2002.

18. CARVALHO, R.M. et al. A review of polymerization contraction: the influence of stress development versus stress relief. Oper Dent, v.21, n.1, p.17-24, Jan./Feb. 1996. 
19. CARVALHO, R.M. et al. Long-term mechanical properties of EDTA-demineralized dentin matrix. J Adhes Dent, v.2, n.3, p.193-9, Autumn. 2000.

20. CAUGHMAN, W.F.; RUEGGEBERG, F.A.; CURTIS Jr., J.W. Clinical guidelines for photocuring restorative resins. J Amer Dent Assoc, v.126, n.9, p.1280-6, Sept. 1995.

21. CAVALCANTE, L.M. et al. Influence of polymerization technique on microleakage and microhardness of resin composite restorations. Oper Dent, v.28, n.2, p. 200-6, Mar./Apr. 2003.

22. CHAPPELL, R.P. et al. Dentinal tubule anastomosis: a potential factor in adhesive bonding? J Prosthet Dent,v.72, n.2, p.183-8, Aug. 1994.

23. CHERSONI, S. et al. In vivo and in vitro permeability of one-step self-etch adhesives. J Dent Res, v.83, n.6, p.459-64, June 2004.

24. CHOI, K.K.; CONDON, J.R.; FERRACANE, J.L. The effects of adhesive thickness on polymerization contraction stress of composite. J Dent Res, v.79, n.3, p.812-7, Mar. 2000.

25. D'ALPINO, P. H. et al. In vitro evaluation of internal adaptations of class $V$ resin composite restorations using three techniques of polymerization. J Dent Res, p. A420, 2002. Special issue. /Abstract n.3401/

26. D'ALPINO, P.H. et al. Use of fluorescent compounds in assessing bonded restorations - a literature review. J Dent, 2006. /In press/

27. DAVIDSON, C.L. Lining and elasticity. In: PRATI, C. Factors influencing the quality of composite restorations: theory and practice. 1997, p.87-96.

28. DAVIDSON, C.L.; DAVIDSON-KABAN, S.S. Handling of mechanical stresses in composite restorations. Dent Update, v.25, n.7, p.274-9, Sept. 1998. 
29. DAVIDSON, C.L.; DE GEE, A.J. Relaxation of polymerization contraction stresses by flow in dental composites. J Dent Res, v.63, n.2, p.146-8, Feb. 1984.

30. DAVIDSON, C.L.; DE GEE, A.J. Light-curing units, polymerization, and clinical implications. J Adhes Dent, v.2, n.3, p.167-73, Autumn. 2000.

31. DAVIDSON, C.L.; DE GEE, A.J.; FEILZER, A. The competition between the composite-dentin bond strength and the polymerization contraction stress. $\mathbf{J}$ Dent Res, v.63, n.12, p.1396-9, Dec. 1984.

32. DAVIDSON, C.L.; FEILZER, A.J. Polymerization shrinkage and polymerization shrinkage stress in polymer-based restoratives. J Dent, v.25, n.6, p.435-40, Nov. 1997.

33. DAVIDSON-KABAN, S.S. et al. The effect of curing light variations on bulk curing and wall-to-wall quality of two types and various shades of resin composites. Dent Mater,v.13, n.6, p.344-52, Nov. 1997.

34. DAYAN, D.; BINDERMAN, I.; MECHANIC, G.L. A preliminary study of activation of collagenase in carious human dentine matrix. Arch Oral Biol, v.28, n.2, p.185-7, 1983.

35. DE ALMEIDA, J.B. et al. Three different methods to evaluate microleakage of packable composites in Class II restorations. Oper Dent, v.28, n.4, p. 45360, July/Aug. 2003.

36. De MUNCK, J. et al. Micro-tensile bond strength of two adhesives to Erbium:YAG-lased vs. bur-cut enamel and dentin. Eur J Oral Sci, v.110, n.4, p.322-9, Aug. 2002.

37. DENK, W.; STRICKLER, J.H.; WEBB, W.W. Two-photon laser scanning fluorescence microscopy. Science, v.248, n.4951, p.73-6, Apr. 1990.

38. DENNISON, J.B. et al. Effect of variable light intensity on composite shrinkage. J Prosthet Dent,v.84, n.5, p.499-505, Nov. 2000. 
39. DIASPRO, A. Confocal and two-photon microscopy- foundations, applications, and advances. New York, Wiley-Liss, 2002.

40. DIASPRO, A.; ROBELLO, M. Two-photon excitation of fluorescence for threedimensional optical imaging of biological structures. J Photochem Photobiol B, v.55, n.1, p.1-8, Mar. 2000.

41. DORFER, C.E. et al. The nanoleakage phenomenon: influence of different dentin bonding agents, thermocycling and etching time. Eur J Oral Sci, v.108, n.4, p.346-51, Aug. 2000.

42. D'SOUZA, P.D. et al. Dentin bonding systems: a comparative stury of SEM and CLSM used to visualize the resin-dentin interface. Acta Med Dent Helv, v.4, n.1, p.20-6, 1999.

43. EMAMI, N.; SODERHOLM, K.J.; BERGLUND, L.A. Effect of light power density variations on bulk curing properties of dental composites. J Dent, v.31, n.3, p.189-96, Mar. 2003.

44. ERNST, C.P. et al. Stress reduction in resin-based composites cured with a twostep light-curing unit. Amer J Dent, v.13, n.2, p.69-72, Apr. 2000.

45. FAN, P.L. et al. Curing-light intensity and depth of cure of resin-based composites tested according to international standards. J Amer Dent Assoc,v.133, n.4, p.429-34, Apr. 2002.

46. FEILZER, A.J.; DE GEE, A.J.; DAVIDSON, C.L. Setting stress in composite resin in relation to configuration of the restoration. J Dent Res, v.66, n.11, p.1636-9, Nov. 1987.

47. FEILZER, A.J. et al. Influence of light intensity on polymerization shrinkage and integrity of restoration-cavity interface. Eur J Oral Sci, v.103, n.5, p.322-6, Oct. 1995.

48. FELIX, C.A.; PRICE, R.B. The effect of distance from light source on light intensity from curing lights. J Adhes Dent, v.5, n.4, p.283-91, Winter 2003. 
49. FERRACANE, J.L. Elution of leachable components from composites. J Oral Rehabil, v.21, n.4, p.441-52, July 1994.

50. FERRACANE, J.L. Status of research on new fillers and new resins for dental composites. In: International Symposium of Advanced Adhesive Dentistry; 1999 Dec.; Granada (Spain): Kuraray; 1999. p. 4-29.

51. FERRACANE, J.L.; MITCHEM, J.C. Relationship between composite contraction stress and leakage in Class V cavities. Amer J Dent, v.16, n.4, p.239-43, Aug. 2003.

52. FERRACANE, J.L. et al. Wear and marginal breakdown of composites with various degrees of cure. J Dent Res, v.76, n.8, p.1508-16, Aug. 1997.

53. FERRARI, M. et al. Collagen degradation in endodontically treated teeth after clinical function. J Dent Res, v.83, n.5, p.414-9, May 2004.

54. FINGER, W.J.; INOUE, M.; ASMUSSEN, E. Effect of wettability of adhesive resins on bonding to dentin. Amer J Dent, v.7, n.1, p.35-8, Feb. 1994.

55. FUSAYAMA, T. Factors and prevention of pulp irritation by adhesive composite resin restorations. Quintessence Int, v.18, n.9, p.633-41, Sept. 1987.

56. FUSAYAMA, T. et al. Non-pressure adhesion of a new adhesive restorative resin. J Dent Res, v.58, n.4, p.1364-70, Apr. 1979.

57. GARRETT, Q. et al. Effect of charged groups on the adsorption and penetration of proteins onto and into carboxymethylated poly(HEMA) hydrogels. Biomaterials, v.19, n.23, p.2175-86, Dec. 1998.

58. GIACHETTI, L.; BERTINI, F.; SCAMINACI RUSSO, D. Investigation into the nature of dentin resin tags: a scanning electron microscopic morphological analysis of demineralized bonded dentin. J Prosthet Dent, v.92, n.3, p.233-8, Sept. 2004. 
59. GOPFERICH, A. Mechanisms of polymer degradation and erosion. Biomaterials, v.17, n.2, p.103-14, Jan. 1996.

60. GORACCI, G.; MORI, G. Scanning electron microscopic evaluation of resindentin and calcium hydroxide-dentin interface with resin composite restorations. Quintessence Int, v.27, n.2, p.129-35, Feb. 1996.

61. GORACCI, G.; MORI, G.; CASA DE'MARTINIS, L. Curing light intensity and marginal leakage of resin composite restorations. Quintessence Int, v.27, n.5, p.355-62, May 1996.

62. GRIFFITHS, B.M. et al. Variable polymerisation shrinkage and the interfacial micropermeability of a dentin bonding system. J Adhes Dent, v.1, n.2, p.11931, Summer 1999.

63. GRIFFITHS, B.M.; WATSON, T.F. Resin-dentin interface of Scotchbond MultiPurpose dentin adhesive. Amer J Dent, v.8, n.4, p.212-6, Aug. 1995.

64. GRIFFITHS, B.M.; WATSON, T.F.; SHERRIFF, M. The influence of dentine bonding systems and their handling characteristics on the morphology and micropermeability of the dentine adhesive interface. J Dent, v.27, n.1, p.63-71, Jan. 1999.

65. GU, M.; SHEPPARD, C.J. Comparison for 3-dimensional imaging properties between 2-photon and single-photon fluorescence microscopy. J Microscopy, v.177, p.128-37, 1995.

66. GWINNETT, A.J. et al. Quantitative contribution of the collagen network in dentin hybridization. Amer J Dent, v.9, n.4, p.140-4, Aug. 1996.

67. HAAK, R.; WICHT, M.J.; NOACK, M.J. Marginal and internal adaptation of extended class I restorations lined with flowable composites. J Dent, v.31, n.4, p.231-9, May 2003.

68. HANNIG, M.; FRIEDRICHS, C. Comparative in vivo and in vitro investigation of interfacial bond variability. Oper Dent, v.26, n.1, p.3-11, Jan./Feb. 2001. 
69. HASEGAWA, T. et al. Depth of cure and marginal adaptation to dentin of xenon lamp polymerized resin composites. Oper Dent, v.26, n.6, p.585-90, Nov./Dec. 2001.

70. HASHIMOTO, M. et al. Fluid movement across the resin-dentin interface during and after bonding. J Dent Res, v.83, n.11, p.843-8, Nov. 2004.

71. HASHIMOTO, M. et al. In vivo degradation of resin-dentin bonds in humans over 1 to 3 years. J Dent Res, v.79, n.6, p.1385-91, June 2000.

72. HASHIMOTO, M. et al. Resin-tooth adhesive interfaces after long-term function. Amer J Dent,v.14, n.4, p.211-5, Aug. 2001.

73. HASHIMOTO, M. et al. Degradation patterns of different adhesives and bonding procedures. J Biomed Mater Res, v.66, n.1, p.324-30, July 2003.

74. HASHIMOTO, M. et al. In vitro degradation of resin-dentin bonds analyzed by microtensile bond test, scanning and transmission electron microscopy. Biomaterials, v.24, n.21, p.3795-803, Sept. 2003.

75. HILTON, T.J. Can modern restorative procedures and materials reliably seal cavities? In vitro investigations. Part 2. Amer J Dent, v.15, n.4, p.279-89, Aug. 2002.

76. HOFMANN, N. et al. The influence of plasma arc vs. halogen standard or softstart irradiation on polymerization shrinkage kinetics of polymer matrix composites. J Dent, v.31, n.6, p.383-93, Aug. 2003.

77. HUANG, G.T.; SODERHOLM, K.J. In vitro investigation of shear bond strength of a phosphate based dentinal bonding agent. Scand J Dent Res, v.97, n.1, p.84-92, Feb. 1989.

78. INOUE, $\mathrm{H}$. et al. Microtensile bond strength of two single-step adhesive systems to bur-prepared dentin. J Adhes Dent, v.3, n.2, p.129-36, Summer 2001. 
79. ITOU, K. et al. Effect of drying methods on hybrid layer thickness. Amer J Dent, v.16, n.5, p.335-9, Oct. 2003.

80. JACOBSEN, T.; FINGER, W.J. Morphology of coupling sites between bonding agents and dentine in vivo and in vitro. J Dent, v.21, n.3, p.150-7, June 1993.

81. JACOBSEN, T.; SODERHOLD, K.J. Some effects of water on dentin bonding. Dent Mater, v.11, n.2, p.132-6, Mar. 1995.

82. JACOBSEN, T.; SODERHOLM, K.J. Effect of primer solvent, primer agitation, and dentin dryness on shear bond strength to dentin. Amer J Dent, v.11, n.5, p.225-8, Oct. 1998.

83. JACOBSEN, T. et al. Effect of composition and complexity of dentin-bonding agents on operator variability--analysis of gap formation using confocal microscopy. Eur J Oral Sci, v.111, n.6, p.523-8, Dec. 2003.

84. JOHNSTON, W.M, LEUNG, R.L.; FAN, P.L. A mathematical model for postirradiation hardening of photoactivated composite resins. Dent Mater, v.1, n.5, p.191-4, Oct. 1985.

85. KANCA, J. Improving bond strength through acid etching of dentin and bonding to wet dentin surfaces. J Amer Dent Assoc, v.123, n.9, p.35-43, Sept. 1992.

86. KANCA, J. Resin bonding to wet substrate. 1. Bonding to dentin. Quintessence Int, v.23, n.1, p.39-41, Jan. 1992.

87. KANCA, J.; SUH, B.I. Pulse activation: reducing resin-based composite contraction stresses at the enamel cavosurface margins. Amer J Dent, v.12, n.3, p.107-12, June 1999.

88. KATAHIRA, N. et al. Comparison of PAC and QTH light sources on polymerization of resin composites. Amer J Dent, v.17, n.2, p.113-7, Apr. 2004. 
89. KNEZEVIC, A. et al. Degree of conversion and temperature rise during polymerization of composite resin samples with blue diodes. J Oral Rehab, v.28, n.6, p.586-91, June 2001.

90. KNEZEVIC, A. et al. Photopolymerization of composite resins with plasma light. $\mathbf{J}$ Oral Rehab., v.29, n.8, p.782-6, Aug. 2002.

91. KOLINIOTOU-KUBIA, E.; JACOBSEN, P.H. The effect of irradiation time on the physical properties of light-cured resins. Clin Mater, v.6, n.1, p.21-8, 1990.

92. KORAN, P.; KURSCHNER, R. Effect of sequential versus continuous irradiation of a light-cured resin composite on shrinkage, viscosity, adhesion, and degree of polymerization. Amer J Dent, v.11, n.1, p.17-22, Feb. 1998.

93. LOSCHE, G.M. Marginal adaptation of Class II composite fillings: guided polymerization vs reduced light intensity. J Adhes Dent, v.1, n.1, p.31-9, Spring 1999.

94. LUTZ, E.; KREJCI, I.; OLDENBURG, T.R. Elimination of polymerization stresses at the margins of posterior composite resin restorations: a new restorative technique. Quintessence Int, v.17, n.12, p.777-84, Dec. 1986.

95. MEHL, A.; HICKEL, R.; KUNZELMANN, K.H. Physical properties and gap formation of light-cured composites with and without 'softstartpolymerization'. J Dent, v.25, n.3-4, p.321-30, May/July 1997.

96. MILLS, R.W.; JANDT, K.D.; ASHWORTH, S.H. Dental composite depth of cure with halogen and blue light emitting diode technology. Brit Dent J, v.186, n.8, p.388-91, Apr. 1999.

97. NAKABAYASHI, N. The hybrid layer: a resin-dentin composite. Proc Finn Dent Soc, v.88, p. 321-9, 1992. Supplement 1.

98. NAKABAYASHI, N.; KOJIMA, K.; MASUHARA, E. The promotion of adhesion by the infiltration of monomers into tooth substrates. J Biomed Mater Res, v.16, n.3, p.265-73, May 1982. 
99. NIKAIDO, T. et al. Evaluation of thermal cycling and mechanical loading on bond strength of a self-etching primer system to dentin. Dent Mater, v.18, n.3, p. 269-75, May 2002.

100. NIKOLAENKO, S.A et al. Influence of c-factor and layering technique on microtensile bond strength to dentin. Dent Mater, v.20, n.6, p.579-85, July 2004.

101. NOMOTO, R.; MCCABE, J.F.; HIRANO, S. Comparison of halogen, plasma and LED curing units. Oper Dent, v.29, n.3, p.287-94, May/June 2004.

102. NOMURA, Y. et al. Thermal analysis of dental resins cured with blue lightemitting diodes (LEDs). J Biomed Mater Res, v.63, n.2, p.209-13, 2002.

103. NUNES, M.F.; SWIFT, E.J.; PERDIGAO, J. Effects of adhesive composition on microtensile bond strength to human dentin. Amer J Dent, v.14, n.6, p.3403, Dec. 2001.

104. OESTERLE, L.J.; NEWMAN, S.M.; SHELLHART, W.C. Rapid curing of bonding composite with a xenon plasma arc light. Am J Orthod Dentofacial Orthop, v.119, n.6, p.610-6, June 2001.

105. OKUDA, M. et al. Long-term durability of resin dentin interface: nanoleakage vs. microtensile bond strength. Oper Dent, v.27, n.3, p.289-96, May/June 2002.

106. PARK, S.H.; KREJCI, I.; LUTZ, F. Microhardness of resin composites polymerized by plasma arc or conventional visible light curing. Oper Dent, v.27, n.1, p.30-7, Jan./Feb. 2002.

107. PASHLEY, D.H.; CARVALHO, R.M. Dentine permeability and dentine adhesion. J Dent, v.25, n.5, p.355-72, Sept. 1997.

108. PASHLEY, D.H. et al. Bond strength versus dentine structure: a modelling approach. Arch Oral Biol, v.40, n.12, p.1109-18, Dec. 1995. 
109. PASHLEY, D.H. et al. Permeability of dentin to adhesive agents. Quintessence Int, v.24, n.9, p.618-31, Sept. 1993.

110. PASHLEY, D.H.; HORNER, J.A.; BREWER, P.D. Interactions of conditioners on the dentin surface. Oper Dent, Supplement 5, p. 137-50, 1992.

111. PASHLEY, D.H. et al. The effects of dentin permeability on restorative dentistry. Dent Clin N Amer, v.46, n.2, p.211-45, Apr. 2002.

112. PASHLEY, D.H. et al. Adhesion testing of dentin bonding agents: a review. Dent Mater, v.11, n.2, p.117-25, Mar. 1995.

113. PAUL, S.J. et al. Effect of water content on the physical properties of model dentine primer and bonding resins. J Dent, v.27, n.3, p.209-14, Mar. 1999.

114. PAUL, S.J. et al. Nanoleakage at the dentin adhesive interface vs microtensile bond strength. Oper Dent, v.24, n.3, p.181-8, May/June 1999.

115. PERDIGAO, J.; RAMOS, J.C.; LAMBRECHTS, P. In vitro interfacial relationship between human dentin and one-bottle dental adhesives. Dent Mater, v.13, n.4, p.218-27, July 1997.

116. PEREIRA, P.N. et al. Relationship between bond strengths and nanoleakage: evaluation of a new assessment method. Amer J Dent, v.14, n.2, p.100-4, Apr. 2001.

117. PEREIRA, P.N. et al. Effect of region and dentin perfusion on bond strengths of resin-modified glass ionomer cements. J Dent, v.28, n.5, p.347-54, July 2000.

118. PEUTZFELDT, A. Resin composites in dentistry: the monomer systems. Eur J Oral Sci, v.105, n.2, p.97-116, Apr. 1997.

119. PEUTZFELDT, A.; ASMUSSEN, E. Determinants of in vitro gap formation of resin composites. J Dent, v.32, n.2, p.109-15, Feb. 2004. 
120. PEUTZFELDT, A.; ASMUSSEN, E. Investigations on polymer structure of dental resinous materials. In: Proceedings of conference on scientific insights into dental ceramics and photopolymer networks. Geneva, Academy of Dental Materials 2004. p. 241.

121. PeUtZfeldt. A.; SAHAFI, A.; ASMUSSEN, E. Characterization of resin composites polymerized with plasma arc curing units. Dent Mater, v.16, n.5, p.330-6, Sept. 2000.

122. $\mathrm{PIOCH}, \mathrm{T}$. et al. Surface characteristics of dentin experimentally exposed to hydrofluoric acid. Eur J Oral Sci, v.111, n.4, p.359-64, Aug. 2003.

123. PIOCH. T. et al. Interfacial micromorphology and tensile bond strength of dentin bonding systems after $\mathrm{NaOCl}$ treatment. J Adhes Dent, v.1, n.2, p.135-42, Summer 1999.

124. $\mathrm{PIOCH}$, T. et al. Nanoleakage at the composite-dentin interface: a review. Amer J Dent, v.14, n.4, p.252-8, Aug. 2001.

125. PIOCH, T. et al. Effect of intrapulpal pressure simulation in vitro on shear bond strengths and hybrid layer formation. Amer J Dent, v.14, n.5, p.319-23, Oct. 2001.

126. $\mathrm{PIOCH}, \mathrm{T}$. et al. The nanoleakage phenomenon: influence of moist vs dry bonding. J Adhes Dent, v.4, n.1, p.23-30, Spring 2002.

127. $\mathrm{PIOCH}, \mathrm{T}$. et al. Influence of different etching times on hybrid layer formation and tensile bond strength. Amer J Dent, v.11, n.5, p.202-6, Oct. 1998.

128. PIOCH, T. et al. Applications of confocal laser scanning microscopy to dental bonding. Adv Dent Res, v.11, n.4, p.453-61, Nov. 1997.

129. POTTER, S.M. Vital imaging: two photons are better than one. Curr Biol, v.6, n.12, p.1595-8, Dec. 1996. 
130. PRATI, C. et al. Dentine permeability and bond quality as affected by new bonding systems. J Dent, v.23, n.4, p.217-26, Aug. 1995.

131. PRATI, C. et al. Marginal hybrid layer in Class V restorations. Oper Dent, v.25, n.3, p.228-33, May/June 2000.

132. PRICE, R.B. et al. Effect of stepped vs. continuous light curing exposure on bond strengths to dentin. Amer J Dent, v.13, n.3, p.123-8, June 2000.

133. REES, J.S.; JACOBSEN, P.H. The polymerization shrinkage of composite resins. Dent Mater,v.5, n.1, p. 41-4, Jan. 1989.

134. REIS, A. et al. Durability of resin dentin interfaces: effects of surface moisture and adhesive solvent component. Dent Mater, v.20, n.7, p.669-76, Sept. 2004.

135. REIS, A.F. et al. Ultramorphological analysis of resin-dentin interfaces produced with water-based single-step and two-step adhesives: nanoleakage expression. J Biomed Mater Res, v.71B, n.1, p.90-8, Oct. 2004.

136. RETIEF, D.H. Do adhesives prevent microleakage? Int Dent J, v.44, n.1, p.1926, Feb. 1994.

137. RUEGGEBERG, F. A. Contemporary issues in photocuring. Comp Continuing Educ Dent, v.20, n.25, p.S4-15, Nov. 1999.

138. RUEGGEBERG, F.A.; CAUGHMAN, W.F.; CURTIS Jr., J.W. Effect of light intensity and exposure duration on cure of resin composite. Oper Dent, v.19, n.1, p.26-32, Jan./Feb. 1994.

139. RUEGGEBERG, F.A. et al. Factors affecting cure at depths within light-activated resin composites. Amer J Dent, v.6, n.2, p.91-5, Apr. 1993.

140. RUEGGEBERG, F.A.; CRAIG, R.G. Correlation of parameters used to estimate monomer conversion in a light-cured composite. J Dent Res, v.67, n.6, p.932-7, June 1988. 
141. RUEGGEBERG, F.A.; HASHINGER, D.T.; FAIRHURST, C.W. Calibration of FTIR conversion analysis of contemporary dental resin composites. Dent Mater, v.6, n.4, p.241-9, Oct. 1990.

142. RUEGGEBERG, F.A.; MARGESON, D.H. The effect of oxygen inhibition on an unfilled/filled composite system. J Dent Res, v.69, n.10, p.1652-8, Oct. 1990.

143. RUYTER, I.E. Monomer systems and photopolymerization. In: International Symposium on Posterior Composite Resin Dental Restorative Materials. The Netherlands, Peter Szulc Publishing Company, 1985. p.109137.

144. SAKAGUCHI, R.L.; BERGE, H.X. Reduced light energy density decreases postgel contraction while maintaining degree of conversion in composites. $\mathbf{J}$ Dent, v.26, n.8, p.695-700, Nov. 1998.

145. SANO, $\mathrm{H}$. et al. Tensile properties of mineralized and demineralized human and bovine dentin. J Dent Res, v.73, n.6, p.1205-11, June 1994.

146. SANO, H. et al. Relationship between surface area for adhesion and tensile bond strength - evaluation of a micro-tensile bond test. Dent Mater, v.10, n.4, p.236-40, July 1994.

147. SANO, H. et al. Nanoleakage: leakage within the hybrid layer. Oper Dent, v.20, n.1, p.18-25, Jan./Feb. 1995.

148. SANO, $\mathrm{H}$. et al. Long-term durability of dentin bonds made with a self-etching primer, in vivo. J Dent Res, v.78, n.4, p.906-11, Apr. 1999.

149. SANO, H. et al. Comparative SEM and TEM observations of nanoleakage within the hybrid layer. Oper Dent, v.20, n.4, p.160-7, July/Aug. 1995.

150. SCHUPBACH, P.; KREJCI, I.; LUTZ, F. Dentin bonding: effect of tubule orientation on hybrid-layer formation. Eur J Oral Sci, v.105, n.4, p.344-52, Aug. 1997. 
151. SHIMADA, Y.; TAGAMI, J. Effects of regional enamel and prism orientation on resin bonding. Oper Dent, v.28, n.1, p.20-7, Jan./Feb. 2003.

152. SHONO, Y. et al. Durability of resin-dentin bonds. J Adhes Dent, v.1, n.3, p.211-8, Autumn 1999.

153. SIDHU, S.K.; WATSON, T.F. Interfacial characteristics of resin-modified glassionomer materials: a study on fluid permeability using confocal fluorescence microscopy. J Dent Res, v.77, n.9, p.1749-59, Sept. 1998.

154. SILIKAS, N.; ELIADES, G.; WATTS, D.C. Light intensity effects on resincomposite degree of conversion and shrinkage strain. Dent Mater, v.16, n.4, p.292-6, July 2000 .

155. SPENCER, K.R.; FERGUSON, J.W.; WIESENFELD, D. Current concepts in the management of oral squamous cell carcinoma. Aust Dent J, v.47, n.4, p.284-9, Dec. 2002.

156. SPENCER, P.; WANG, Y. Adhesive phase separation at the dentin interface under wet bonding conditions. J Biomed Mater Res, v.62, n.3, p.447-56, Dec. 2002.

157. SPENCER, P. et al. Interfacial chemistry of the dentin/adhesive bond. J Dent Res, v.79, n.7, p.1458-63, July 2000.

158. STRITIKUS, J.; OWENS, B. An in vitro study of microleakage of occlusal composite restorations polymerized by a conventional curing light and a PAC curing light. J clin pediat Dent, v.24, n.3, p.221-7, Spring 2000.

159. SULIMAN, A.A.; BOYER, D.B.; LAKES, R.S. Cusp movement in premolars resulting from composite polymerization shrinkage. Dent Mater, v.9, n.1, p.6-10, Jan. 1993.

160. SWIFT Jr., E.J.; PERDIGAO, J.; HEYMANN, H.O. Bonding to enamel and dentin: a brief history and state of the art, 1995. Quintessence Int, v.26, n.2, p.95-110, Feb. 1995. 
161. TAKAHASHI, A. et al. In vivo long-term durability of the bond to dentin using two adhesive systems. J Adhes Dent, v.4, n.2, p.151-9, Summer 2002.

162. TAKAHASHI, A. et al. Effects of mechanical properties of adhesive resins on bond strength to dentin. Dent Mater, v.18, n.3, p.263-8, May 2002.

163. TANUMIHARJA, M. et al. Field-emission scanning electron microscopy of resindentin interface morphology of seven dentin adhesive systems. J Adhes Dent, v.2, n.4, p.259-69, Winter 2000.

164. TAO, L.; PASHLEY, D.H. Shear bond strengths to dentin: effects of surface treatments, depth and position. Dent Mater, v.4, n.6, p.371-8, Dec. 1988.

165. TAO, L.; PASHLEY, D.H. Dentin perfusion effects on the shear bond strengths of bonding agents to dentin. Dent Mater, v.5, n.3, p.181-4, May 1989.

166. TAY, F.R. et al. Mechanical disruption of dentin collagen fibrils during resindentin bond testing. J Adhes Dent, v.2, n.3, p.175-92, Autumn 2000.

167. TAY, F.R. et al. Single-bottle adhesives behave as permeable membranes after polymerization. I. In vivo evidence. J Dent, v.32, n.8, p.611-21, Nov. 2004.

168. TAY, F.R.; GWINNETT, A.J.; WEI, S.H. The overwet phenomenon: an optical, micromorphological study of surface moisture in the acid-conditioned, resindentin interface. Amer J Dent, v.9, n.1, p.43-8, Feb. 1996.

169. TAY, F.R.; GWINNETT, A.J.; WEI, S.H. Ultrastructure of the resin-dentin interface following reversible and irreversible rewetting. Amer J Dent, v.10, n.2, p.77-82, Apr. 1997.

170. TAY, F.R.; PASHLEY, D.H. Aggressiveness of contemporary self-etching systems. I: Depth of penetration beyond dentin smear layers. Dent Mater, v.17, n.4, p.296-308, July 2001.

171. TAY, F.R.; PASHLEY, D.H. Water treeing - a potential mechanism for degradation of dentin adhesives. Amer J Dent, v.16, n.1, p.6-12, Feb. 2003. 
172. TAY, F.R. et al. Single-step adhesives are permeable membranes. J Dent, v.30, n.7-8, p.371-82, Sept./Nov. 2002.

173. TERRY, D.A. Direct applications of a nanocomposite resin system: Part 1--The evolution of contemporary composite materials. Pract Proced Aesth Dent, v.16, n.6, p.417-22, July 2004.

174. TITLEY, K. et al. The composition and ultrastructure of resin tags in etched dentin. Amer J Dent, v.8, n.5, p.224-30, Oct. 1995.

175. TOLEDANO, M. et al. Microtensile bond strength of several adhesive systems to different dentin depths. Amer J Dent, v.16, n.5, p.292-8, Oct. 2003.

176. TOLEDANO, M. et al. Influence of self-etching primer on the resin adhesion to enamel and dentin. Amer J Dent, v.14, n.4, p.205-10, Aug. 2001.

177. TORSTENSON, B.; BRANNSTROM, M. Contraction gap under composite resin restorations: effect of hygroscopic expansion and thermal stress. Oper Dent, v.13, n.1, p.24-31, Winter 1988.

178. UNO, S.; ASMUSSEN, E. Marginal adaptation of a restorative resin polymerized at reduced rate. Scand J Dent Res, v.99, n.5, p.440-4, Oct. 1991.

179. UNTERBRINK, G.L.; MUESSNER, R. Influence of light intensity on two restorative systems. J Dent, v.23, n.3, p.183-9, June 1995.

180. VAN MEERBEEK, B. et al. Comparative SEM and TEM examination of the ultrastructure of the resin-dentin interdiffusion zone. J Dent Res, v.72, n.2, p.495-501, Feb. 1993.

181. VAN MEERBEEK, B. et al. The clinical performance of adhesives. J Dent, v.26, n.1, p.1-20, Jan. 1998.

182. VAN MEERBEEK, B. et al. Hybridization effectiveness of a two-step versus a three-step smear layer removing adhesive system examined correlatively by TEM and AFM. J Adhes Dent, v.1, n.1, p.7-23, Spring 1999. 
183. VANDEWALLE, K.S. et al. Effect of energy density on properties and marginal integrity of posterior resin composite restorations. Dent Mater, v.20, n.1, p.96-106, Jan. 2004.

184. VERSLUIS, A.; TANTBIROJN, D.; DOUGLAS, W.H. Do dental composites always shrink toward the light? J Dent Res, v.77, n.6, p.1435-45, June 1998.

185. VERSLUIS, A.; TANTBIROJN, D.; DOUGLAS, W.H. Distribution of transient properties during polymerization of a light-initiated restorative composite. Dent Mater, v.20, n.6, p.543-53, July 2004.

186. WALSHAW, P.R.; McCOMB, D. SEM evaluation of the resin-dentin interface with proprietary bonding agents in human subjects. J Dent Res, v.73, n.5, p.1079-87, May 1994.

187. WANG, Y.; SPENCER, P. Hybridization efficiency of the adhesive/dentin interface with wet bonding. J Dent Res, v.82, n.2, p.141-5, Feb. 2003.

188. WATSON, T.F. A confocal optical microscope study of the morphology of the tooth/restoration interface using Scotchbond 2 dentin adhesive. J Dent Res, v.68, n.6, p.1124-31, June 1989.

189.WATSON, T.F. Applications of confocal scanning optical microscopy to dentistry. Brit Dent J., v.171, n.9, p.287-91, Nov . 1991.

190. WATSON, T.F. Fact and artefact in confocal microscopy. Adv Dent Res, v.11, n.4, p.433-41, Nov. 1997.

191. WATSON, T.F.; BOYDE, A. Tandem scanning reflected light microscopy: applications in clinical dental research. Scanning Microsc, v.1, n.4, p.1971-81, Dec. 1987.

192. WATSON, T.F.; BOYDE, A. Confocal light microscopic techniques for examining dental operative procedures and dental materials. A status report for the American Journal of Dentistry. Amer J Dent, v.4, n.4, p.193-200, Aug. 1991. 
193. WATSON, T.F.; WILMOT, D.M. A confocal microscopic evaluation of the interface between Syntac adhesive and tooth tissue. J Dent, v.20, n.5, p.302-10, Oct. 1992.

194. YE, Q. et al. Kinetics of photo-polymerization of dental adhesives: light source and intensity. IADR Baltimore. 2005. J Dent Res, Special issue. /Abstract n. $1819 /$

195. YEARN, J.A. Factors affecting cure of visible light activated composites. Int Dent J, v.35, n.3, p.218-25, Sept. 1985.

196. YOSHIKAWA, T.; BURROW, M.F.; TAGAMI, J. The effects of bonding system and light curing method on reducing stress of different C-factor cavities. J Adhes Dent, v.3, n.2, p.177-83, Summer 2001.

197. YOSHIKAWA, T. et al. Effects of dentin depth and cavity configuration on bond strength. J Dent Res, v.78, n.4, p.898-905, Apr. 1999. 
Abstract 


\begin{abstract}
Influence of light-curing sources on bond strength and on interfacial micromorphology of resin composite restorations - a fluorescence microscopy study
\end{abstract}

The purpose of the present in vitro study was to evaluate the effect of different light-curing sources on interfacial micromorphology and on bond strength of resin composite restorations. Class I preparations $(6.0 \mathrm{~mm}$ long, $4.5 \mathrm{~mm}$ wide, $2.5 \mathrm{~mm}$ deep) were made in extracted human third molars, after abrading cusps, following university approved HAC guidelines. Restorations were placed in bulk, using a dentin bonding agent (DBA) / resin composite (RC): Adper Single Bond / Filtek Z250. Restoratives were light-cured as follows: $\mathrm{XL} 3000$ (QTH: $540 \mathrm{~mW} / \mathrm{cm}^{2}$ ); Elipar FreeLight2 (LED: $750 \mathrm{~mW} / \mathrm{cm}^{2}$ ); Arc Light II (PAC: 2,130 $\mathrm{mW} / \mathrm{cm}^{2}$ ). Nine experimental groups were developed from the different light combinations with respect to curing the DBA/COMP: QTH/QTH; QTH/LED; QTH/PAC; LED/LED; LED/QTH; LED/PAC; PAC/PAC; PAC/QTH; PAC/LED. Fluorescing agent (Rhodamine $B$ ) was added to the DBA, highlighting the bonded interface and surrounding structures. A different colored dye (FTIC-Dextran) was placed in the pulp chamber for 3 hours, allowing time to diffuse toward the different-colored interface. The teeth were then embedded, sectioned, and microscopically analyzed using fluorescence microscopy (Two-Photon Laser) at 40x magnification. Micromorphology quantitative and qualitative evaluations were: quality and thickness of hybrid layer; micropermeability test, adhesive layer thickness; quality and sealing ability of resin tags; location and extension of gaps. For bond strength test, the same experimental groups were obtained. After restorative procedures, the teeth were stored in distilled water for $24 \mathrm{~h}$ at $37^{\circ} \mathrm{C}$. After this time period, resin layers were added to the restoration surface (providing same dentin/resin length), and then sectioned and subjected to microtensile test in a universal testing machine. Kinetics conversion parameters were also evaluated in an FT-IR spectrophotometer (total conversion, maximum rate of cure, time when maximum rate occurred, conversion at maximum rate, conversion at maximum rate/ total conversion ratio). The same restorative materials were applied to the ATR device, attached to the spectrophotometer, and 
then polymerized according to manufacturer's instructions. Data was statistically analyzed as mentioned below. Statistical analyses revealed that different light sources influenced the kinetics conversion (one-way ANOVA, $p<0,05$ ). It was found an inverse relation between power density and monomer conversion when polymerizing DBA. For resin composite (bottom), there was a positive relation between power density and total conversion. High intensity, broad banded PAC light produced higher maximum rate of cure (in $\% / s$ ), in shorter times. In terms of micromorphology, no significant difference was found in terms of quality and thickness of hybrid layer (two-way ANOVA, $p>0.05$ ). No significant difference was noted for in quality and in sealing ability of tags (Kruskal Wallis, $p>0.05$ ). QTH/QTH presented higher percentages of best scores for both parameters. Adhesive layers were found to be significantly thicker when PAC light was used to polymerize DBA. Even thought it was also found no significance in micropermeability scores (Kruskal Wallis, $p>0.05$ ), it was found higher percentage of best scores for control QTH/QTH. Photo-polymerizing DBA using PAC produced lower incidence of gap formation, irrespective of RC curing source. Combination PAC/QTH presented significantly higher bond strength and LED/QTH, the lower (two-way ANOVA, Dunnet's pos-hoc test, $p<0.05$ ). Part of interfacial micromorphology parameters and bond strength were more dependent on the photo-polymerization source used for dentin-bonding agent than for resin composite. Photo-polymerizing DBA using PAC produced best results for adhesive thickness, gap location, and bond strength. Although QTH/QTH, LED/LED, and PAC/PAC combinations produced similar general results, it was found inherent characteristics when analysing tested parameters. Different light curing units influence bond strength and some parameters of micromorphology. 